DOE/RL-93-23

Revision 0

\title{
N Springs Expedited \\ Response Action Proposal
}

Date Published

January 1994

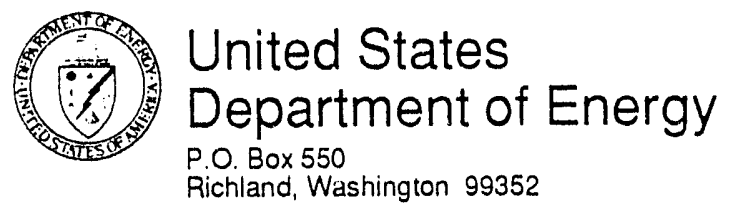

Approved for Public Release 


\section{EXECUTIVE SUMMARY}

The release of large volumes of water to $1301-\mathrm{N}$ and $1325-\mathrm{N}$ liquid waste disposal facilities (LWDF) at the $100 \mathrm{~N}$ Area caused contaminants, principally strontium-90, to be carried toward the Columbia River through the groundwater. Since shutdown of the N Reactor, releases to the LWDF have been discontinued. The contamination is transported to the river as a result of the natural groundwater movement. The contaminated groundwater at $\mathrm{N}$ Springs flows into the river through seeps and springs along the river's edge. This expedited response action (ERA) is an interim action proposed to significantly reduce the flux of strontium-90 to the river.

The principal objective of the N Springs ERA Proposal is to evaluate alternatives and recommend an alternative or alternatives that best meet the selection criteria as prescribed by the Comprehensive Environmental Response, Compensation, and Liability Act of 1980, including a demonstration of cost effectiveness. The methodology used for evaluation, cost analysis, and alternative recommendation is the engineering evaluation/cost analysis (EE/CA). Because final remediation of the contaminated groundwater beneath the $100 \mathrm{~N}$ Area is not a principal objective of the ERA, there is some flexibility in the scope of the ERA and the degree to which reduction of strontium- 90 flux to the river is achieved. The $\mathrm{EE} / \mathrm{CA}$ is to identify a system which optimizes the degree of benefit produced for the costs incurred.

Results from groundwater monitoring programs indicate that the principal contaminants in the groundwater downgradient of the $1301-\mathrm{N}$ and $1325-\mathrm{N}$ cribs are tritium and strontium-90. Other radionuclides are also present, but these are below regulatory limits.

A modeling effort was conducted prior to the EE/CA for different purposes. The results from this effort are used in this proposal; however, because the model was constructed with different objectives, some uncertainties are inherent in the evaluation of the alternatives using the model.

The preferred alternative should provide a high degree of protectiveness balanced with acceptable risks and reasonable costs. However, as a result of the additional analysis performed in response to regulatory comments, it is now concluded that a preferred alternative cannot be confidently recommended in view of the technical and cost uncertainties of both alternatives. Therefore, both the slurry wall and the pump and treat alternatives are recommended as preferred alternatives. Additional information may be needed prior to implementing a single preferred action. The following activities are proposed to gather this information:

- $\quad$ Time consistent groundwater and spring sampling - All wells associated with the N Springs area and the strontium-90 plume, including the wells at the springs, should be sampled at the same time to allow construction of representative contaminant plume maps. This information will be used to construct the groundwater model. 
- $\quad$ Additional groundwater flow and contaminant transport modeling for the alternatives - The model will be constructed specifically for the evaluation of these alternatives using current $\mathrm{N}$ Springs area conditions. The model will be used to evaluate performance of the alternatives including hydraulic control to optimize elements of each alternative, such as wall length and placement, well spacing, and well pumping rates, and to determine remediation time frames.

- $\quad$ Subsurface characterization - Two borings will be drilled to define the confining layer depth and thickness. Sediment samples from the aquifer will be collected to determine aquifer physical parameters including strontium-90 sorption characteristics.

- $\quad$ Slurry wall implementability test - A test panel using the deep soil mixture equipment will be constructed in a clean zone in the $100 \mathrm{~N}$ Area. Slurry formulations consistent with the $\mathrm{N}$ Springs area water and soils will be developed. Following placement of the test panel, the panel will be drilled to determine if the panel meets permeability criteria.

- Treatability studies for ion exchange and reverse osmosis treatment systems A bench-scale treatability study will be conducted for the ion exchange treatment system. Information will be generated (in coordination with other treatability tests being conducted on-site) on appropriate ion exchange media, media loading, waste generation, and costs. A pilot-scale reverse osmosis treatability test will be conducted in the field to determine an acceptable membrane, membrane loading, waste generation, waste water treatment, and cost.

- Wetlands regulatory review/assessment - A regulatory review will be condusted to determine the requirements needed to conduct the ERA near the river. Wetlands, floodplain, and Wild and Scenic Rivers Act regulations will be reviewed to identify requirements; appropriate federal and state agencies will be contacted if necessary. If warranted, a wetlands assessment will be conducted prior to alternative implementation. This issue directly affects the location, size, effectiveness, and cost of the slurry wall.

- Endangered vegetation study - A study of endangered species located at the $\mathrm{N}$ Springs area will be conducted to identify potential impacts.

- Additional analysis and refinement of costs - The cost estimates will be refined based on the additional information gathere' in the other activities.

The information gathered from the above activities will be used to implement the preferred alternative. This preferred alternative will continue through the design phase and ultimately be implemented. 
DOE $\backslash$ RL-93-23, Rev. 0

\section{ACRONYMS}

$\begin{array}{ll}\text { ALARA } & \text { as low as reasonably achievable } \\ \text { ARAR } & \text { applicable or relevant and appropriate requirements } \\ \text { CERCLA } & \text { Comprehensive Environmental Response, Compensation, and Liability Act } \\ \text { CFR } & \text { Code of Federal Regulations } \\ \text { COPC } & \text { chemicals of potential concern } \\ \text { DOE } & \text { U.S. Department of Energy } \\ \text { DST } & \text { double-shell tanks } \\ \text { Ecology } & \text { Washington State Department of Ecology } \\ \text { EE/CA } & \text { engineering evaluation/cost analysis } \\ \text { EPA } & \text { U.S. Environmental Protection Agency } \\ \text { ERA } & \text { expedited response action } \\ \text { ERDF } & \text { Environmental Restoration Disposal Facility } \\ \text { HCRC } & \text { Hanford Cultural Resources Clearance } \\ \text { HCRL } & \text { Hanford Cultural Resources Laboratory } \\ \text { IRM } & \text { interim response measure } \\ \text { FS } & \text { feasibility study } \\ \text { LWDF } & \text { liquid waste disposal facility } \\ \text { MCL } & \text { maximum contaminant level } \\ \text { NCP } & \text { National Contingency Plan } \\ \text { NERP } & \text { National Environmental Research Park } \\ \text { NPDES } & \text { National Pollutant Discharge Elimination System } \\ \text { O\&M } & \text { operating and maintenance } \\ \text { ORNL } & \text { Oak Ridge National Laboratory } \\ \text { RAO } & \text { removal action objective } \\ \text { RCRA } & \text { Resource Conservation and Recovery Act } \\ \text { R\&D } & \text { research and development } \\ \text { RL } & \text { Richland Operations Office } \\ \text { SARA } & \text { Superfund Amendments and Reauthorization Act } \\ \text { TBC } & \text { to-be-considered } \\ \text { Tri-Party } & \\ \text { Agreement } & \text { Hanford Federal Facility Agreement and Consent Order } \\ \text { WHC } & \text { Westinghouse Hanford Company } \\ \end{array}$




\section{CONTENTS}

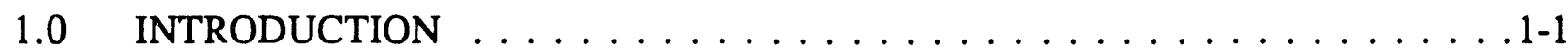

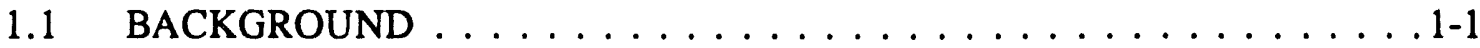

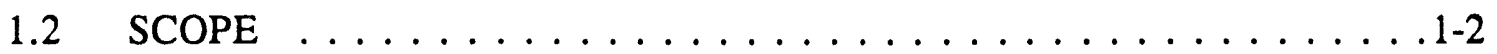

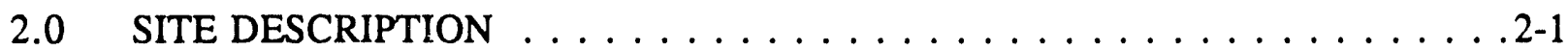

2.1 PHYSICAL SETTING $\ldots \ldots \ldots \ldots \ldots \ldots \ldots \ldots \ldots \ldots \ldots \ldots \ldots .2-1$

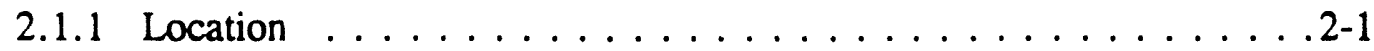

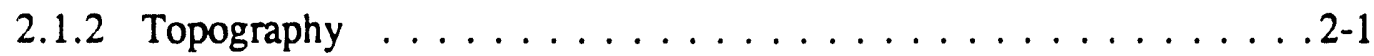

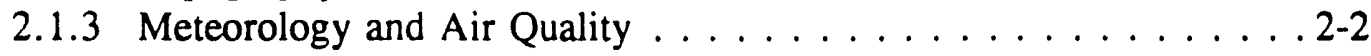

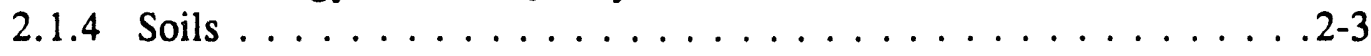

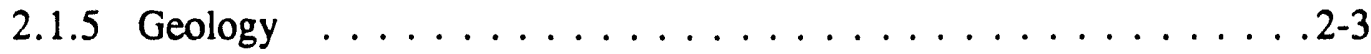

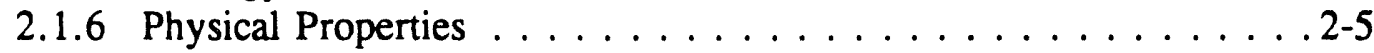

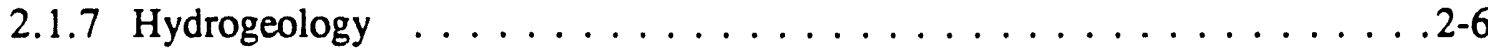

2.1.7 Biological Resources . . . . . . . . . . . . . . . . 2-10

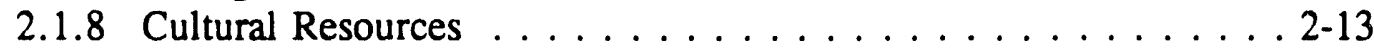

2.1 .9 Visual Resources . . . . . . . . . . . . . . . . 2-14

2.1.10 Land and Water Use . . . . . . . . . . . . . . 2-14

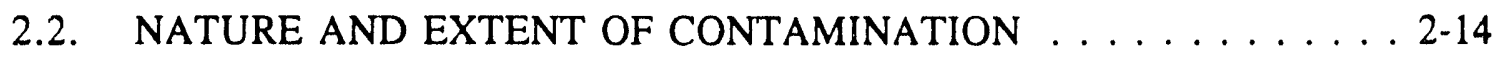

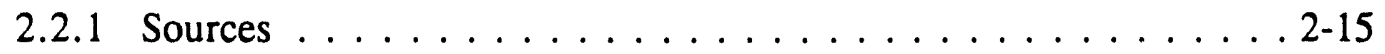

2.2.2 Soil Contaminants $\ldots \ldots \ldots \ldots \ldots \ldots \ldots \ldots . \ldots \ldots$

2.2.3 Groundwater Contaminants . . . . . . . . . . . 2-17

3.0 REMOVAL ACTION OBJECTIVES DEVELOPMENT $\ldots \ldots \ldots \ldots \ldots$. . . . . .

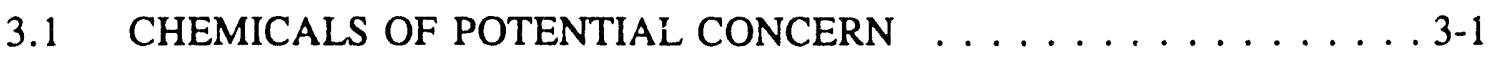

3.2 POTENTIAL APPLICABLE OR RELEVANT AND APPROPRIATE

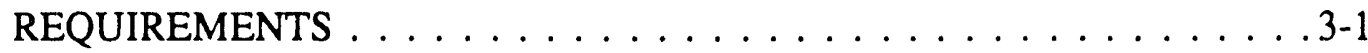

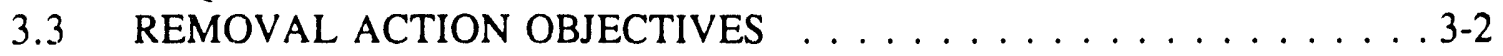

4.0 IDENTIFICATION OF REMOVAL ACTION TECHNOLOGIES $\ldots \ldots \ldots \ldots$. . .

5.0 SCREENING OF REMOVAL ACTION TECHNOLOGIES $\ldots \ldots \ldots \ldots \ldots$. . $\ldots$.

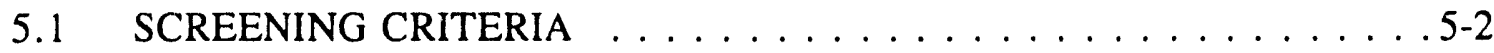

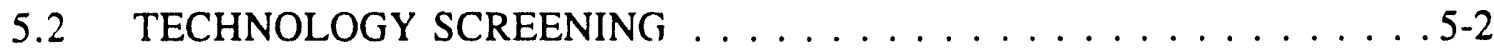

5.2 .1 Pump and Treat - Extraction Wells ............. 5-3

5.2.2 Pump and Treat - Treatment Process Options . . . . . . . . . 5-3

5.2.3 Pump and Treat - Treated Water Disposal Options . . . . . . . 5-4

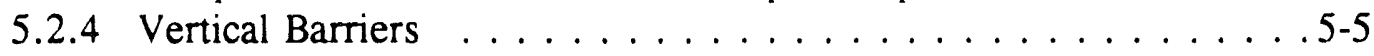

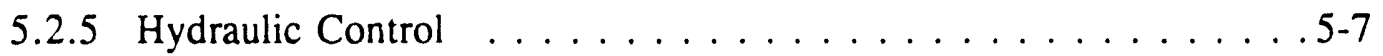

5.2.6 Miscellaneous Technologies $\ldots \ldots \ldots \ldots \ldots \ldots \ldots$. . . . . . . .

6.0 DETAILED ANALYSIS OF REMOVAL ACTION ALTERNATIVES . . . . . 6-1

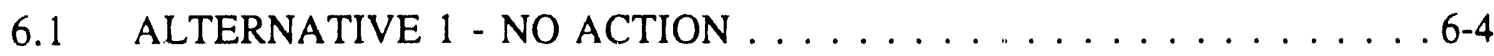

6.1 .1 Description . . . . . . . . . . . . . . . . 6-4

6.1 .2 Technical Feasibility $\ldots \ldots \ldots \ldots \ldots .6 \ldots$ 
6.1 .3 Cost Considerations . . . . . . . . . . . . . . 6-6

6.1 .4 Institutional Considerations . . . . . . . . . . . . . 6-6

6.1 .5 Environmental Impacts . . . . . . . . . . . . . . . . . .6-6

6.2 ALTERNATIVE 2 - PUMP AND TREAT $\ldots \ldots \ldots \ldots \ldots \ldots .6 .6$

6.2 .1 Description . . . . . . . . . . . . . . . .6-6

6.2 .2 Technical Feasibility . . . . . . . . . . . 6-12

6.2 .3 Cost Considerations . . . . . . . . . . . . . . . 6-13

6.2 .4 Institutional Considerations . . . . . . . . . . . 6-14

6.2 .5 Environmental Impacts . . . . . . . . . . . . . . 6-14

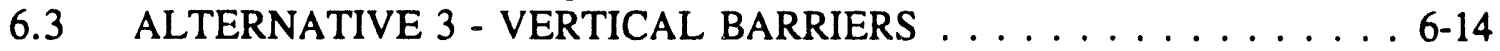

6.3.1 Description . . . . . . . . . . . . . . . . . . 6-14

6.3 .2 Technical Feasibility . . . . . . . . . . . . 6-18

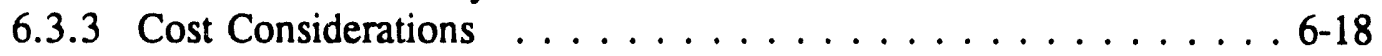

6.3.4 Institutional Considerations . . . . . . . . . . . 6-19

6.3.5 Environmental Impacts . . . . . . . . . . . . . . 6-19

6.4 ALTERNATIVE 4 - HYDRAULIC CONTROL . . . . . . . . . 6-19

6.4 .1 Description . . . . . . . . . . . . . . . . 6-19

6.4 .2 Technical Feasibility . . . . . . . . . . . . . . 6-20

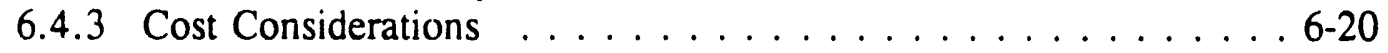

6.4 .4 Institutional Considerations . . . . . . . . . . 6-21

6.4 .5 Environmental Impacts $\ldots \ldots \ldots \ldots \ldots \ldots \ldots .6 \ldots .21$

7.0 COMPARATIVE ANALYSIS OF REMOVAL ACTION ALTERNATIVES . . 7-1

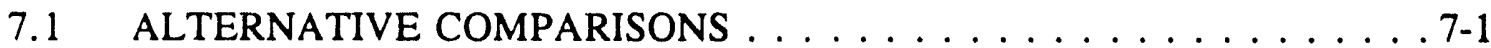

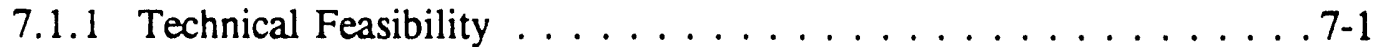

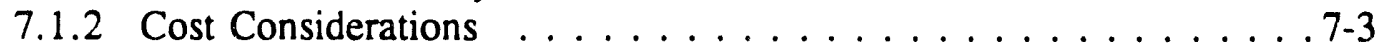

7.1.3 Institutional Considerations . . . . . . . . . . . . 7-4

7.1 .4 Environmental Impacts $\ldots \ldots \ldots \ldots \ldots \ldots \ldots . . \ldots \ldots$

7.2 COST-BENEFIT ANALYSIS $\ldots \ldots \ldots \ldots \ldots \ldots \ldots \ldots$

8.0 PREFERRED ALTERNATIVE $\ldots \ldots \ldots \ldots \ldots \ldots \ldots$. . . . . . . .

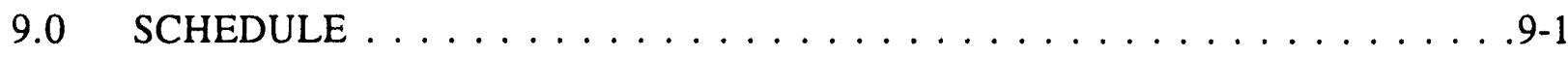

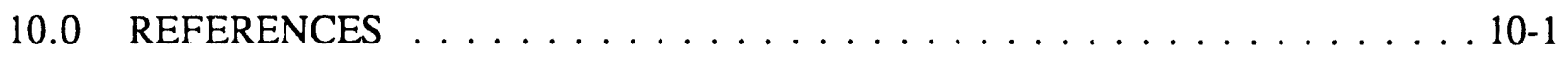

APPENDIX:

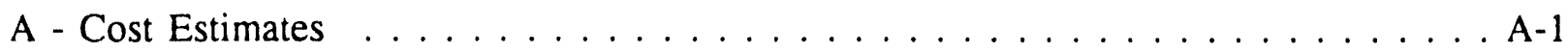


DOE\RL-93-23, Rev. 0

CONTENTS (cont)

\section{FIGURES:}

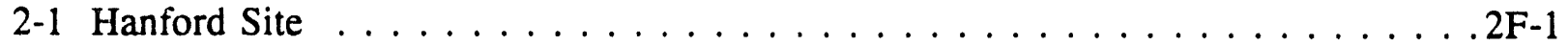

2-2 N Springs ERA Site Location . . . . . . . . . . . . . . . . . . . 2F-2

2-3 Conceptual Geologic and Hydrogeologic Column . . . . . . . . . . . . . 2F-3

2-4 $100 \mathrm{~N}$ Area Water Table - Average Monthly Water Levels June 1992 to May $1993 \ldots \ldots$. . . . . . . . . . . . . . . . . . . . . . 2F-4

2-5 $100 \mathrm{~N}$ Area Water Table - May $1991 \ldots \ldots \ldots$. . . . . . . . . . . . . . 2F-5

2-6 Strontium-90 Activity in $100 \mathrm{~N}$ Area Groundwater During

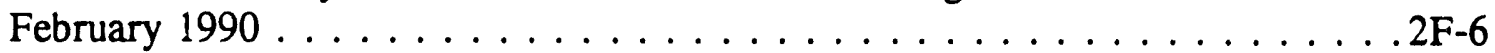

2-7 Tritiuin Activity in $100 \mathrm{~N}$ Area Groundwater During February $1990 \ldots$. . . . . . 2F-7

2-8 Strontium-90 Activity in the $100 \mathrm{~N}$ Area Groundwater During

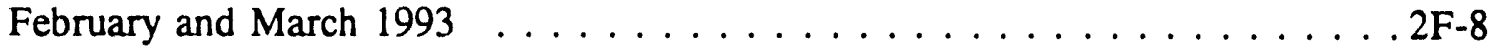

2-9 Tritium Activity in the $100 \mathrm{~N}$ Area Groundwater During February

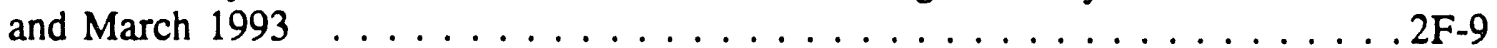

2-10 Average Strontium-90 Concentrations in the N Springs from 1985

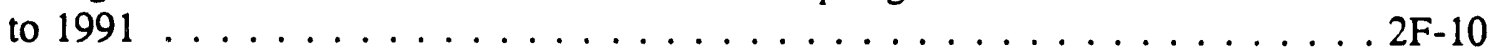

6-1 Groundwater Levels and Strontium-90 Concentration Estimates Based on Groundwater Modeling for the Year 2002 - No Action Alternative . . . . . . 6F-1

6-2 Alternative 2 - Pump and Treat Overall Process Flow Diagram . . . . . . . . . . 6F-2

6-3 Groundwater Levels and Strontium-90 Concentration Estimates Based on Groundwater Modeling for the Year 2002 - Five-Well Pump and Treat System

6-4 Alternative 2 - Pump and Treat, Ion Exchange Treatment Process Flow Diagram . . . . . . . . . . . . . . . . . . . . . . . . 6F-4

6-5 Alternative 2 - Pump and Treat, Reverse Osmosis Treatment Process Flow Diagram . . . . . . . . . . . . . . . . . . . . . . . .6F-5

6-6 Groundwater Levels and Strontium-90 Concentration Estimates Based on Groundwater Modeling for the Year 2002 - Slurry Wall Alternative . . . . . . . 6F-6

6-7 Approximate Location of Slurry Wall . . . . . . . . . . . . . . . . . . 6F-7

6-8 Side View, Slurry Wall . . . . . . . . . . . . . . . . . . . . . . . 6F-8

6-9 Upgradient Hydraulic Control Steady State Hydraulic Head Distribution and Individual Well Pumping Rates . . . . . . . . . . . . . . . . 6F-9

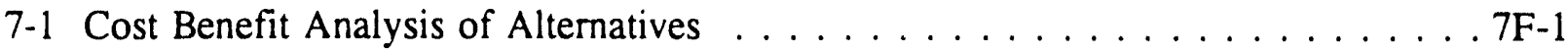

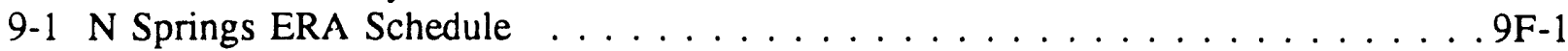

\section{TABLES:}

?-1 Radionuclides/Chemical Wastes Disposed to 1301-N Liquid Waste Disposal Facility $.2 \mathrm{~T}-1$

2-2 Water Flow Rates and Strontium-90 Discharges to 1301-N and 1325-N Liquid Waste Disposal Facilities .

2-3 Radionuclides and Chemical Wastes Disposed to 1325-N Liquid Waste Disposal Facility . . . . . . . . . . . . . . . . . . . . . . . 2T-3

2-4 Groundwater Quality in the Vicinity of the N Springs ERA Site . . . . . . . . 2T-4a 


\section{CONTENTS (cont)}

TABLES (cont):

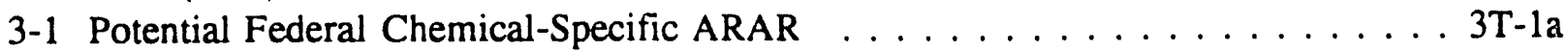

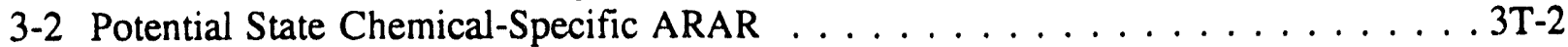

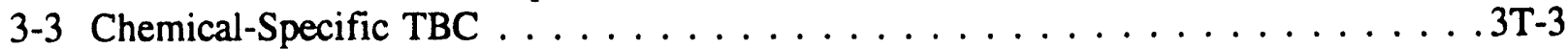

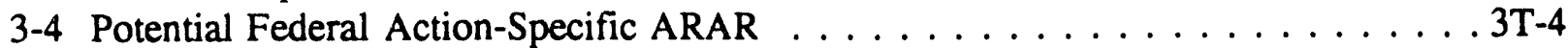

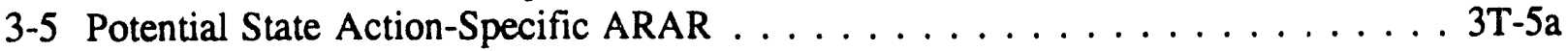

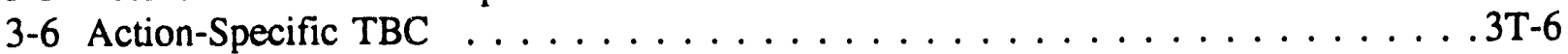

3-7 Potential Federal Location-Specific ARAR . . . . . . . . . . . . . . 3T-7

3-8 Potential State Location-Specific ARAR . . . . . . . . . . . . . . . 3T-8

3-9 Location-Specific TBC . . . . . . . . . . . . . . . . . . . . . . . 3T-9

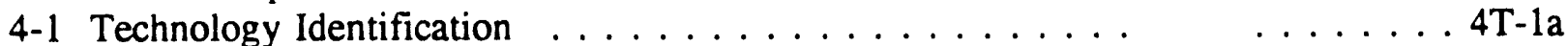

5-1 Screening of Technologies and Process Options . . . . . . . . . . . . . . 5T-1a

6-1 Annual Strontium-90 Flux (Ci/yr) Through Two Summation Sections Placed

33 and $100 \mathrm{ft}$ from the River as Predicted by Modeling . . . . . . . . . . 6 6T-1

6-2 Technical Feasibility Evaluation for No Action Alternative . . . . . . . . . . . 6T-2

6-3 Institutional Considerations Evaluation for No Action Alternative . . . . . . . . 6 6T-3

6-4 Environmental Impacts Evaluation of No Action Alternative . . . . . . . . . . 6 6T-4

6-5 Technical Feasibility Evaluation for Groundwater Extraction Options . . . . . . . . 6T-5

6-6 Technical Feasibility Evaluation of Groundwater Treatment Options . . . . . . . 6T 6

6-7 Technical Feasibility Evaluation of Treated Water Disposal Options . . . . . . . 6T-7a

6-8 Cost Evaluation for Groundwater Extraction Options . . . . . . . . . . . . . 6T-8

$6-9$ Cost Evaluation for Ion Exchange System . . . . . . . . . . . . . . . 6T-9

6-10 Cost Evaluation for Reverse Osmosis System . . . . . . . . . . . . . . 6 6T-10

$6-11$ Cost Evaluation for River Disposal . . . . . . . . . . . . . . . 6 6T-11

6-12 Cost Evaluation for $\mathrm{N}$ Area Crib Disposal . . . . . . . . . . . . . . . 6T -12

6-13 Cost Evaluation for $\mathrm{N}$ Area Reinjection . . . . . . . . . . . . . . . . 6T -13

6-14 Cost Evaluation for 200 Area Crib Disposal . . . . . . . . . . . . . . 6 6T-14

6-15 Institutional Considerations Evaluation for Groundwater

Extraction Options ..................... . . . . . . . . . .

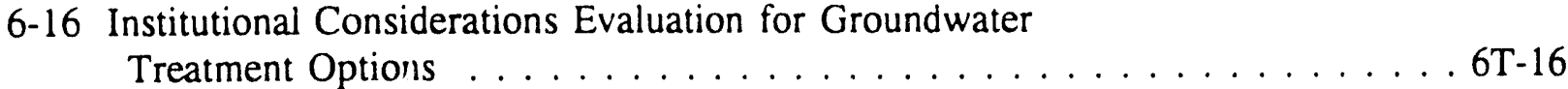

6-17 Institutiona' Considerations Evaluation for Treated Water

Disposal Options . . . . . . . . . . . . . . . . . . . . . . 6T-17

6-18 Environmental Impacts Evaluation for Groundwater Extraction Options . . . . 6 6T-18

6-19 Environmental Impacts Evaluation for Treated Water Disposal Options . . . . . 6T-19a

6-20 Technical Feasibility Evaluation for Slurry Wall Alternative . . . . . . . . . 6T-20

6-21 Cost Evaluation for Slurry Wall Alternative . . . . . . . . . . . . . . 6T-21

6-22 Institutional Considerations Evaluation for Slurry Wall Alternative . . . . . . . 6T-22

6-23 Environmental Impacts Evaluation for Slurry Wall Alternative . . . . . . . . . . 6T-23

6-24 Technical Feasibility Evaluation for Hydraulic Control Alternative . . . . . . . 6T-24

6-25 Cost Evaluation for Hydraulic Control Alternative . . . . . . . . . . . . 6 6T-25

6-26 Institutional Considerations Evaluation for Hydraulic Control Alternative . . . 6T-26

6-27 Environmental Impacts Evaluation for Hydraulic Control Alternative . . . . . . 6T-27

$7-1$ Cost Comparison of Alternatives . . . . . . . . . . . . . . . T 


\subsection{INTRODUCTION}

Since signing the Hanford Federal Facility Agreement and Consent Order (Tri-Party Agreement) in 1989 (Ecology et al. 1989), the parties to the agreement have recognized the need to modify the approach to conducting investigations, studies, and cleanup actions at Hanford with a goal of maximizing efficiency, optimizing use of limited resources, and achieving cleanup in the earliest possible time frame. To implement this approach, the parties have jointly developed the Hanford Past-Practice Strategy (DOE-RL 1991a). The principles of the strategy are embodied in the Hanford Federal Facility Agreement and Consent Order Change Package (Ecology et al. 1991).

The strategy defines a non-time-critical expedited response action (ERA) as a response action "needed to abate a threat to human health or welfare or the environment where sufficient time exists for formal planning prior to initiation of response. A non-time-critical ERA may also address a situation encompassing levels of contamination which do not pose an immediate danger or threat to human health or welfare or the environment, but which might justify a response action by the need to control the spread of contamination, to abate a threat, or provide for a greater overall cost effectiveness by more timely response." In accordance with the past-practice strategy, the U.S. Department of Energy (DOE) proposes to conduct an ERA at the N Springs, located in the Hanford $100 \mathrm{~N}$ Area, to substantially reduce the strontium- 90 transport into the river through the groundwater pathway.

The N Springs ERA is part of the Senior Executive Committee Agreement on resolution of the Tri-Party Agreement Milestone M-14 Change Request Dispute dated January 8, 1993 (Ecology et al. 1993). The N Springs ERA is a joint agreement by the parties to the Tri-Party Agreement. The purpose of this ERA proposal is to provide sufficient information to select a preferred alternative at $\mathrm{N}$ Springs. The nature of an ERA requires that alternatives developed for the ERA be field ready; therefore, all the technologies proposed for the ERA should be capable of addressing the circumstances at $N$ Springs. A comparison of these alternatives is made based on protectiveness, cost, technical feasibility, and institutional considerations to arrive at a preferred alternative. Following the selection of an alternative, a design phase will be conducted; the design phase will include a detailed look at design parameters, performance specifications, and costs of the selected alternative. Testing will be conducted as required to generate design data.

\subsection{BACKGROUND}

Past-practices in the $100 \mathrm{~N}$ Area have resulted in contamination of the soils and underlying groundwater in the reactor vicinity. The release of large volumes of water to the 1301-N and 1325-N liquid waste disposal facilities (LWDF) at the $100 \mathrm{~N}$ Area caused contaminants, principally strontium-90, to be carried toward the Columbia River through the groundwater. Since shutdown of the N Reactor, the releases to the LWDF have been discontinued (see Section 2.2.3). The contamination is transported to the river as a result of the natural groundwater movement. The contaminated groundwater at N Springs flows into the river through seeps and springs along the river's edge and is rapidly diluted to very low 
levels. N Springs represents a significant pathway for strontium-90 release into the river. The ERA is proposed to substantially reduce the flux of strontium-90 migration into the river.

This ERA meets the criteria as defined in the Hanford Past-Practice Strategy (DOE-RL 1991a) and as detailed in the Site Selection Process for Expedited Response Actions at the Hanford Site (Gustafson 1991). The ERA will be conducted as a non-time-critical removal action under the regulatory authority as defined in Title 40 Code of Federal Regulations (CFR) 300.415 and as described in the $N$ Springs Expedited Response Action Project Plan (IT Corporation 1992).

In accordance with the past-practice strategy and the requirements of removal actions under 40 CFR 300.415, the ERA does not necessarily constitute the final remedial action for the $100 \mathrm{~N}$ Area operable unit(s), but will, to the extent practicable, contribute to the efficient performance of the final remedial actions with respect to the contaminant release(s). In accordance with 40 CFR 300.415 (i), removal actions shall, to the extent practicable considering the exigencies of the situation, attain applicable or relevant and appropriate requirements (ARAR).

The principal objective of the N Springs ERA Proposal is to evaluate alternatives and recommend a single alternative or multiple alternatives that best meet the selection criteria as prescribed by Comprehensive Environmental Response, Compensation, and Liability Act of 1980 (CERCLA), including a demonstration of cost effectiveness. The methodology used for evaluation, cost analysis, and alternative recommendation is referred to as an engineering evaluation/cost analysis (EE/CA). Because final remediation of the contaminated groundwater beneath the $100 \mathrm{~N}$ Area is not a principal objective of the ERA, there is some flexibility in the scope of the ERA and the degree to which reduction of strontium-90 contamination to the river is achieved. The EE/CA, which is conducted as part of the ERA proposal preparation, attempts to identify an ERA system which optimizes the degree of benefit produced for the costs incurred.

\subsection{SCOPE}

The scope of the ERA proposal is to identify, screen, and compare removal action alternatives that eliminate or substantially reduce the flux of strontium-90 to the river. The goal of the proposal is a recommended cost effective alternative that meets the ERA objectives. The proposal includes a summary of new and existing information to select an alternative. Additional information concerning costs and performance specifications will be collected during the design phase.

The CERCLA limits fund-financed removal actions to a 24-month duration and \$2 million in costs. While these limitations do not apply to federal actions, the ERA should be reviewed at an appropriate time after implementation for conversion to an interim response action (IRM). The ERA should, to the extent practical, contribute to the effective performance of any final actions. Therefore, the ERA should be reevaluated as planning in the $100 \mathrm{~N}$ Area proceeds to ensure compatibility with future actions. 


\subsection{SITE DESCRIPTION}

This section provides a background discussion of the $100 \mathrm{~N}$ Area physical setting and the nature and extent of contamination to be addressed by the N Springs ERA.

\subsection{PHYSICAL SETTING}

The Hanford Site lies within the semi-arid Pasco Basin of the Columbia Plateau in southeastern Washington State. The Hanford Site occupies an area of about $560 \mathrm{mi}^{2}(1,450$ $\mathrm{km}^{2}$ ) north of the confluence of the Snake and Yakima Rivers with the Columbia River. The Columbia River flows through the northern part of the site and, on turning south, forms the eastern site boundary. Rattlesnake Mountain, the Yakima Ridge, and Umtanum Ridge form the southwestern and western boundaries while the Saddle Mountains form the northern boundary of the Hanford Site. Two small east-west trending ridges, Gable Mountain and Gable Butte, rise above the plateau of the central part of the Hanford Site. The cities of Richland, Pasco, and Kennewick (Tri-Cities) are the nearest population centers to the Hanford Site. (See Figure 2-1.)

The subsections below describe the physical setting of the N Springs area, including both a discussion of the natural characteristics of the site and the human-induced influences on the site.

\subsubsection{Location}

The N Springs are a series of springs and seeps located along the southern edge of the Columbia River in and adjacent to the $100 \mathrm{~N}$ Area (Figure 2-2). The N Springs ERA site is located west and north of the 1301-N and 1325-N cribs and is bordered by the Columbia River, the $100 \mathrm{~N}$ Area, and the 600 Area. The N Reactor (and associated support facilities), located in the $100 \mathrm{~N}$ Area, was operated as a dual production reactor (plutonium and by-product steam for electricity generation) from 1963 until 1987. The City of Richland is approximately 27 air or 38 river mi (43 air or 61 river $\mathrm{km}$ ) south of the $100 \mathrm{~N}$ Area. The $\mathrm{N}$ Springs are included in the 100-NR-2 Operable Unit.

\subsubsection{Topography}

The topography of the $100 \mathrm{~N}$ Area ranges in elevation from approximately $387 \mathrm{ft}$ $(118 \mathrm{~m})$ amsl at the Columbia River to approximately $460 \mathrm{ft}(140 \mathrm{~m}) \mathrm{amsl}$ on the east side of the area. Some of the area has been reworked as part of construction of the reactor building and related facilities and is relatively flat with an elevation of approximately $450 \mathrm{ft}(137 \mathrm{~m})$ amsl. The slope along the river bank is steep with gradients of at least $15 \%$. Elevations within the N Springs ERA site range from approximately $387 \mathrm{ft}(118 \mathrm{~m})$ amsl along the river to approximately $490 \mathrm{ft}(150 \mathrm{~m})$ amsl in unimproved areas. The surrounding terrain is 
hummocky, probably as a result of catastrophic flooding associated with Pleistocene glaciation.

\subsubsection{Meteorology and Air Quality}

The Hanford Site weather is monitored at the Hanford Meteorology Station and at remote stations throughout the site. Station 13 of the Hanford Telerietry Network is located in the $100 \mathrm{~N}$ Area.

The climate of the Hanford Site is semi-arid and is greatly affected by the Cascade Mountains to the west. The Hanford Site receives an average of 6.3 in $(16 \mathrm{~cm})$ of precipitation annually. The precipitation falls mainly in the winter months, with nearly half of the annual precipitation falling between November and February. Precipitation of 0.5 in $(1.3 \mathrm{~cm})$ or more falling within a 24 -hour period occurs only twice per year on the average. Instances of 1.0 in $(2.5 \mathrm{~cm})$ or more of precipitation within a 24-hour period are infrequent, with only four occurrences between 1946 and 1980 (Cushing 1991).

Winter monthly average snowfall varies from 5.3 in $(13.5 \mathrm{~cm})$ in January to 0.3 in $(0.8 \mathrm{~cm})$ in March. The record snowfall of 24.4 in $(62 \mathrm{~cm})$ occurred in February 1916. During the months of December through February, snowfall accounts for about $38 \%$ of all precipitation (Cushing 1991).

The average annual relative humidity between 1946 and 1980 was $54.4 \%$. Humidity is higher in winter months than during the summer (Cushing 1991).

The Cascade Mountains serve as a source of cold air drainage and have a considerable effect on the winds at Hanford. The gravity drainage, plus topographic channeling, results in northwest to west-northwest prevailing wind directions. The average mean monthly speed for the period 1945 is 1980 was $7.7 \mathrm{mi} / \mathrm{h}(12.4 \mathrm{~km} / \mathrm{h})$ with monthly means ranging from $6.1 \mathrm{mi} / \mathrm{h}(9.8 \mathrm{~km} / \mathrm{h})$ in December to $9.2 \mathrm{mi} / \mathrm{h}(14.8 \mathrm{~km} / \mathrm{h})$ in June (Stone et al. 1983). Peak gust speeds range from 63 to $80 \mathrm{mi} / \mathrm{h}(101$ to $129 \mathrm{~km} / \mathrm{h})$ and are generally associated with southwest to west-southwest winds (Stone et al. 1983).

Daily maximum and minimum temperatures range from an average of $36^{\circ} \mathrm{F}\left(2^{\circ} \mathrm{C}\right)$ in January to $95^{\circ} \mathrm{F}\left(35^{\circ} \mathrm{C}\right)$ in late July. There are, on average, 55 days during the summer months with maximum temperatures $>90^{\circ} \mathrm{F}\left(32^{\circ} \mathrm{C}\right)$. From mid-November through midMarch, minimum temperatures average $<32^{\circ} \mathrm{F}\left(0^{\circ} \mathrm{C}\right)$ with the minimum in early January averaging $21^{\circ} \mathrm{F}\left(-6^{\circ} \mathrm{C}\right)$. The record maximum temperature is $115^{\circ} \mathrm{F}\left(46^{\circ} \mathrm{C}\right)$ and the record minimum is $-27^{\circ} \mathrm{F}\left(-32.8^{\circ} \mathrm{C}\right)$ (Cushing 1991$)$.

The actual annual evapotranspiration under current conditions for the Hanford Site is estimated to be 6.1 in $(15.5 \mathrm{~cm})$ (Bauer and Vaccaro 1990). 


\subsubsection{Soils}

Hajek (1966) lists and describes 15 different soil types on the Hanford Site, ranging from sand to silty sandy loam. Soils in the $100 \mathrm{~N}$ Area are described as either a sandy or stony loam. The sandy loam described by Hajek (1966) as surface soil is dark colored, while subsoil is dark-grayish-brown, medium textured, underlain by gravelly material. The stony loam is described as similar to the sandy loam; however, the stony loam contains gravel to boulder-sized debris released from melting glaciers.

\subsubsection{Geology}

The following discussions are based on all of the data available for the $100 \mathrm{~N}$ Area. The geologic and hydrologic discussions are primarily from Hartman and Lindsey (1993), which presents a detailed description of the $100 \mathrm{~N}$ Area hydrogeology.

2.1.5.1 Structure. Structurally, the Hanford Site lies in the eastern Yakima Fold Belt. This belt consists of a series of segmented, narrow, asymmetric, and generally east-west trending anticlines. Between these anticlines lie broad, shallow synclines. The Hanford Site is situated in the Pasco Basin, a structural basin. Within the Pasco Basin, the Gable Mountain anticline separates the Wahluke and Cold Creek synclines; the $100 \mathrm{~N}$ Area is on the north limb of the Wahluke syncline. South of the $100 \mathrm{~N}$ Area, basalt flows and the older units of the Ringold Formation dip steeply to the north. Beneath and to the north of the area, those same strata dip at shallow angles (about $5^{\circ}$ ) to the south (Lindberg 1993a). The structural setting of south-central Washington and the Hanford Site is discussed in DOE (1988) and Reidel et al. (1989, 1992, 1993).

2.1.5.2 Stratigraphy. The $100 \mathrm{~N}$ Area is underlain by: (1) Pleistocene-aged ( $<2$ million years old) cataclysmic flood deposits of the Hanford formation, (2) late Miocene to middle Pliocene-aged ( $<8.5$ to $>3.4$ million years old) alluvial-lacustrine deposits of the Ringold Formation, and (3) basalts of the Miocene-aged (17 to 6.5 million years old) Columbia River Basalt Group (Figure 2-3). Local surficial Holocene deposits are also found. The uppermost basalt unit beneath the $100 \mathrm{~N}$ Area is the 10.5 million year old Elephant Mountain Member of the Saddle Mountains Basalt. Only two boreholes penetrate to the Elephant Mountain Member at the site. Detailed discussions of the Saddle Mountains Basalt can be found in Reidel and Fecht (1981).

2.1.5.2.1 Ringold Formation. The Ringold Formation in the northern part of the Hanford Site consists of a mix of fluvial gravels, fluvial sands, overbank deposits, paleosols, and lake deposits (Lindsey 1991, 1992). Characteristics of these deposits, also referred to as facies associations, and Ringold stratigraphic subdivisions are described for the Hanford Site in Lindsey (1991) and Reidel et al. (1993). Lindsey (1992), Lindberg (1993a, b), and Lindsey and Jaeger (1993) describe the Ringold Formation in the area surrounding the $100 \mathrm{~N}$ Area. The Ringold Formation ranges from 450 to $494 \mathrm{ft}$ (136 to $150 \mathrm{~m}$ ) thick in the only two boreholes in the $100 \mathrm{~N}$ Area that reach the top of the basalts (Hartman and Lindsey 1993). 
Fluvial gravel dominated deposits of unit $\mathrm{A}$ form the base of the Ringold Formation in the $100 \mathrm{~N}$ Area as observed in boreholes 699-81-62 and 699-84-59. Unit A ranges from 12 to $25 \mathrm{ft}(3.6$ to $7.6 \mathrm{~m})$ thick in these two boreholes. The unit is not present beneath the $100 \mathrm{H}$ Area (Lindsey and Jaeger 1993), nor in boreholes north of the Columbia River on the Wahluke Slope. It is not known where unit A pinches out between these locations and the $100 \mathrm{~N}$ Area (Hartman and Lindsey 1993).

Unit $A$ is overlain in succession by the lower mud unit (approximately $100 \mathrm{ft}[30 \mathrm{~m}]$ thick), unit B (66 to $71 \mathrm{ft}$ [20 to $21.5 \mathrm{~m}$ ] thick), a paleosol-overbank interval (125 to $141 \mathrm{ft}$ [38 to $43 \mathrm{~m}$ ] thick), unit $\mathrm{C}$ (10 to $15 \mathrm{ft}$ [ 3 to $4.5 \mathrm{~m}$ ] thick), another paleosol-overbank interval (55 to $96 \mathrm{ft}$ [17 to $29 \mathrm{~m}$ ] thick), and unit $\mathrm{E}$ (17 to $65 \mathrm{ft}$ [5.2 to $20 \mathrm{~m}$ ] thick). The lower mud unit consists of a lower naleosol-dominated interval and an upper lake deposit-dominated interval. Units $B$ and $C$ are both dominated by fluvial sands with lesser, but still common, silty overbank deposits and minor fluvial gravels. The paleosol-overbank intervals between units $B$ and $C$ and between units $C$ and $E$ are dominated by silt-rich deposits that contain locally abundant pedogenic carbonate development and minor sand interbeds (generally $<10 \mathrm{ft}[3 \mathrm{~m}]$ thick). The top of the paleosol/overbank interval beneath unit $\mathrm{E}$ ranges from 349 to $359 \mathrm{ft}(106$ to $109 \mathrm{~m})$ amsl in the $100 \mathrm{~N}$ Area. Fluvial gravels form the uppermost Ringold unit in the area, unit $E$. The gravels of unit $E$ are continuous beneath the entire $100 \mathrm{~N}$ site (Hartman and Lindsey 1993).

2.1 5.2.2 Hanford Formation. Gravels dominate the Hanford formation in the 100 $\mathrm{N}$ Area. It is 19 to $77 \mathrm{ft}(5.8$ to $23 \mathrm{~m})$ thick. These gravels are typical of the gravel-dominated facies of the Hanford formation, based on examination of borehole samples and gravel pits in the area. Characteristics of these gravels across the region are discussed in Baker et al. (1991) and Reidel et al. (1993). Other Hanford formation facies (sand-dominated and silt-dominated) appear to be lacking in the $100 \mathrm{~N}$ Area.

Two main lithologies comprise the gravel-dominated facies in the $100 \mathrm{~N}$ Area: (1) a pebble-cobble unit and (2) a cobble-boulder unit. Pebble-cobble lithologies dominate the Hanford formation in the $100 \mathrm{~N}$ Area and occur in all the boreholes studied. These deposits generally are similar to Hanford formation gravels elsewhere in the 100 Area. They are well stratified, uncemented, clast supported, and have a sand-rich matrix. Open-framework textures, which are typical of the gravel facies on a regional scale, are absent in the few shallow gravel pits found in the northern part of the Hanford Site. However, the presence of this texture cannot be dismissed because it is so common elsewhere. Borehole logs and the few outcrops available suggest silt layers are rare to absent, although experience elsewhere on the Hanford Site suggests they may be present locally (Hartman and Lindsey 1993).

The cobble-boulder unit occurs throughout most of the $100 \mathrm{~N}$ Area at or near the top of the Hanford formation. Where present, this unit is usually between 10 and $20 \mathrm{ft}$ ( 3 and 6 $\mathrm{m})$ thick, although it has been observed at up to $49 \mathrm{ft}(15 \mathrm{~m})$ thick. Reconnaissance mapping and interpretation of borehole log descriptions indicate clasts at least $3 \mathrm{ft}(1 \mathrm{~m})$ in diameter are common. Except for increased clast size, the cobble-boulder unit displays characteristics typical of other occurrences of the gravel facies. It is uncemented and generally clast supported, has a sand to granule matrix, and open-framework textures are common. The boulder-rich stratum in the $100 \mathrm{~N}$ Area lies at the northeastern end of an elongate 
cobble-boulder tract that extends to the southwest along the Columbia River through the $100 \mathrm{~K}$ (Lindberg 1993b) and $100 \mathrm{~B} / \mathrm{C}$ (Lindberg 1993a) Areas.

Clastic dikes are a common feature of the Hanford formation throughout the region (Black 1979). The few available outcrops and the dominance of gravelly lithologies found in the Hanford formation suggests clastic dikes are unlikely in the $100 \mathrm{~N}$ Area.

2.1.5.2.3 Hanford-Ringold Contact. Hanford formation gravels overlie Ringold Formation gravels throughout the $100 \mathrm{~N}$ Area. This contact is irregular and was formed by post-Ringold erosion, probably associated with Pleistocene cataclysmic flooding. Several criteria are used to differentiate the two units.

1) The sand fraction in Hanford gravels generally contains $<40 \%$ basalt; Ringold deposits generally contain $>25 \%$ basalt.

2) Hanford gravels may display salt and pepper and gray coloring while Ringold gravels are generally more oxidized and red-brown to yellow-red in color.

3) Ringold gravels generally are consolidated and cementation may be well developed locally. Consequently, drilling rates tend to be slower in the Ringold Formation than in the Hanford formation.

Lindsey and Jaeger (1993) describe the presence of a zone at the base of the Hanford formation that is rich in Ringold-like lithologies. Where it is found this zone is interpreted to be part of the Hanford formation. This zone is interpreted to consist of ripped-up and redeposited Ringold Formation material. While these rip-up horizons tend to be localized, they can make identification of the contact difficult. Where this occurs as many criteria as possible are used to best estimate the position of the contact. In these situations it only may be possible to approximate the top of the Ringold Formation (Hartman and Lindsey 1993).

2.1.5.2.4 Holocene Deposits. Holocene eolian deposits locally overlie the Hanford formation in the $100 \mathrm{~N}$ Area. These deposits are typically heterogenous and poorly mixed and were derived primarily from reworked Hanford formation sediments.

\subsubsection{Physical Properties}

The vadose zone is 65 to $75 \mathrm{ft}(20$ to $23 \mathrm{~m}$ ) thick beneath most of the $100 \mathrm{~N}$ Area. Soil moisture data for the $100 \mathrm{~N}$ Area are limited. Moisture content in wells 199-N-71 through 199-N-77 ranged from 1 to $3 \%$ (Hartman 1992, 1993).

Samples collected during drilling of well 199-N-80 were analyzed for physical properties including grain size, bulk density, specific gravity, saturated hydraulic conductivity, calcium carbonate content, and moisture retention. Data from the three vadose zone samples are summarized in Hartman and Lindsey (1993). 
'Ten vadose zone sites near the river were sampled for laboratory testing as input to a computer model (Connelly et al. 1991). The sites were also equipped with permeameters. The data were used to construct moisture characteristic curves for the unsaturated sediments. Hydrologic parameters derived from the curves are listed in Connelly et al. (1991).

\subsubsection{Hydrogeology}

The $100 \mathrm{~N}$ Area is underlain by the vadose zone, an unconfined aquifer, a series of confined aquifers in the unconsolidated sediments, and a series of confined aquifers in the basalts and interbeds (see Figure 2-3). The unconsolidated sediments of the Ringold Formation contain a series of producing and confining layers. The saturated, unconsolidated sediments are called the "uppermost aquifer system." The unconfıned portion of the system has been defined as the "uppermost aquifer" (Hartman 1993). However, the degree of isolation provided by the confining beds within the Ringold Formation is not well known.

2.1.7.1 Vadose Zone. The vadose zone beneath the $100 \mathrm{~N}$ Area is primarily comprised of unconsolidated sediments of the Hanford formation. This highly permeable unit consists of mainly cobbles, boulders, pebbles, and coarse sand. Drilling data indicate that isolated lenses of silty sand and gravel are also present. The vadose zone also includes the top few feet of the Ringold Formation in some parts of the $100 \mathrm{~N}$ Area. The unsaturated Ringold sediments are similar to the Hanford formation: sands, gravels, and cobbles, with varying fractions of silt. The vadose zone is 65 to $75 \mathrm{ft}(20$ to $23 \mathrm{~m})$ thick beneath most of the 100 N Area (Hartman and Lindsey 1993).

Some perched water was noted during drilling of well 199-N-35 at a depth of approximately $30 \mathrm{ft}(9 \mathrm{~m})$. Well $199-\mathrm{N}-35$ is located immediately adjacent to the $1325-\mathrm{N}$ crib, and it was installed after eftluent disposal to that unit had begun. This well was installed along with wells numbered between 199-N-27 to $199-\mathrm{N}-52$ between 1983 and 1985 to monitor groundwater around the 1325-N LWDF. No other perched groundwater was noted in the $100 \mathrm{~N}$ Area drilling logs (Hartman and Lindsey 1993).

2.1.7.1.1 Hydraulic Properties. Connelly et al. (1991) collected soil samples from the unsaturatated zone for estimating saturated hydraulic conductivities for the vadose zone. These estimates ranged from 1.4 to $170 \mathrm{ft} / \mathrm{d}(0.43$ to $52 \mathrm{~m} / \mathrm{d})$. Connelly et al. (1991) compared these test data with values obtained from Brown and Rowe (1960) and Pratt (1985). Connelly et al. (1991) determined that a vertical hydraulic conductivity value of $3 \mathrm{ft} / \mathrm{d}(1 \mathrm{~m} / \mathrm{d})$ was representative of the vadose zone soils in the area of the LWDF. The values reported in Connelly et al. (1991) were somewhat higher than those reported in the other two studies which were conducted in the field. Connelly et al. (1991) suggested that the difference may be due to "realignment of fine soil and precipitate particles and a decrease of porosity ... until an equilibrium value is attained".

These factors were not present in the Connelly et al. (1991) tests.

2.1.7.2 Uppermost Aquifer. The uppermost aquifer beneath the $100 \mathrm{~N}$ Area is an unconfined sand and gravel unit in the Ringold Formation (unit $E$ in Section 2.1.5.2.1; see Figure 2-3). In some locations the bottom portion of the Hanford formation was also 
saturated when groundwater mounds were present (1964-1989). The base of the aquifer is believed to be a laterally continuous fine-grained unit of paleosols and overbank deposits. Sediments of this unit are believed to range from clay and silt to sand. Most of the wells in the $100 \mathrm{~N}$ Area were completed at the water table; therefore the thickness of the fine-grained unit is not known precisely at all locations (Hartman and Lindsey 1993).

The unconfined aquifer is approximately 40 to $50 \mathrm{ft}(12$ to $15 \mathrm{~m})$ thick beneath the $100 \mathrm{~N}$ Area. Information on the $100 \mathrm{~N}$ Area hydrogeology is summarized from well log data, aquifer test results, water table maps, and published reports (Hartman and Lindsey 1993).

2.1.7.2.1 Hydraulic Properties. Most of the aquifer tests in the $100 \mathrm{~N}$ Area have been short-term pumping tests (often without observation wells) or slug tests. All were conducted in the uppermost aquifer. Transmissivity estimates range from 200 to $200,000 \mathrm{ft}^{2} / \mathrm{d}$ (18 to $18,000 \mathrm{~m}^{2} / \mathrm{d}$ ) (Hartman and Lindsey 1993). A large range of transmissivity would be expected in the $100 \mathrm{~N}$ Area because the geology is heterogeneous. However, the breadth of this range of estimates may also reflect poorly-conducted tests; in most cases, data were collected during well development and aquifer testing was not the primary objective. Gilmore et al. (1992) attempted to narrow the range of hydraulic property estimates using three methods: (1) reanalysis of pumping test data; (2) the Ferris method, using river/aquifer responses; and (3) estimates based on the groundwater flow equation and river level fluctuations. A representative range of transmissivity of the uppermost aquifer is 1,000 to $6,000 \mathrm{ft}^{2} / \mathrm{d}\left(90\right.$ to $\left.540 \mathrm{~m}^{2} / \mathrm{d}\right)$ throughout most of the $100 \mathrm{~N}$ Area. Wells in the northwest (199-N-14 and 199-N-51) seem to show a higher transmissivity (up to $20,000 \mathrm{ft}^{2} / \mathrm{d}\left[1,800 \mathrm{~m}^{2} / \mathrm{d}\right]$ ). These values correspond to horizontal hydraulic conductivity of 50 to $300 \mathrm{ft} / \mathrm{d}(0.02$ to $0.11 \mathrm{~cm} / \mathrm{s}) ; 1,000 \mathrm{ft} / \mathrm{d}(0.35 \mathrm{~cm} / \mathrm{s})$ in the northwest. Specific yield is estimated at 0.1 to 0.3 (Hartman and Lindsey 1993).

Split-spoon samples from the uppermost aquifer in well 199-N-80 were analyzed in the laboratory for vertical hydraulic conductivity. Results ranged from 0.1 to $70 \mathrm{ft} / \mathrm{d}(3.5 \mathrm{x}$ $10^{-5}$ to $0.02 \mathrm{~cm} / \mathrm{s}$ ) (Hartman and Lindsey 1993).

2.1.7.2.2 Groundwater Flow. Unconfined groundwater in the northern Hanford Site generally flows to the north and east. Groundwater discharges to the Columbia River through most of the year, except in the area west of the 100 B Area, where the river appears to recharge the aquifer (Hartman and Lindsey 1993).

Groundwater in the uppermost aquifer beneath the $100 \mathrm{~N}$ Area flows mainly to the north and northwest. Figure 2-4 is a water table map constructed of an average of monthly water levels between June 1992 and May 1993. Averaged data were used to smooth out variations due to river stage changes. Groundwater is inferred to flow toward the river beneath most of the area, and to the north beneath the 1325-N LWDF. Groundwater discharges to the river through riverbank springs and, presumably, through the sediments underwater (Hartman and Lindsey 1993).

The $100 \mathrm{~N}$ Area water table map for May 1991 (Figure 2-5) illustrates the water table when the Columbia River ran at high stage for several months. When river stage is high, 
water flows out of the river into the aquifer. Gilmore et al. $(1990,1991)$ studied the effects of river stage on the aquifer near the 1301-N LWDF. The study demonstrated that the effects of seasonal river stage changes were noticeable up to $1,000 \mathrm{ft}(300 \mathrm{~m})$ inland and daily river-level fluctuations affected groundwater levels up to $750 \mathrm{ft}(230 \mathrm{~m})$ iriland.

Groundwater levels in the $100 \mathrm{~N}$ Area and across the Hanford Site have varied through time because of artificial recharge from liquid waste disposal operations. The water table continues to decline at a slow rate and has nearly returned to a stable level. Changes in water levels in response to changes in river stage are still evident. There may be small groundwater mounds due to recharge from the backwash lake and the sewage lagoons, but there are no wells to measure water levels around these sites (Hartman and Lindsey 1993).

Changes in water levels caused by waste disposal have affected groundwater flow directions in the unconfined aquifer. Groundwater mounds formed beneath the 1301-N, 1325-N, and 1324-N/NA sites at various times in the history of waste disposal at the $100 \mathrm{~N}$ Area. Locally, groundwater flowed outward from these mounds. There are no head data from the years before waste discharge to the sediments at the $100 \mathrm{~N}$ Area began. The natural groundwater flow direction was probably to the north and northwest, toward the river (Hartman and Lindsey 1993).

Vertical groundwater gradients are not well defined in the $100 \mathrm{~N}$ Area. Well 199-N-67 is completed at the water table and well 199-N-69 is completed at the base of the aquifer about $6 \mathrm{~m}(20 \mathrm{ft})$ below the water table. The vertical gradient between 199-N-67 and 199-N-69 appears to be negligible. Well 199-N-39 is completed at the water table, and well 199-N-70 is completed at the base of the aquifer about $20 \mathrm{ft}(6 \mathrm{~m})$ below the water table near the 1325-N LWDF. The vertical gradient between wells 199-N-39 and 199-N-70 also appears to be negligible (Hartman and Lindsey 1993).

There appears to be an observable upward vertical gradient adjacent to the river in the $100 \mathrm{~N}$ Area. Data from the unconfined wells in the 199-N-8 well cluster are sparse except for well 199-N-8S, which is completed slightly below the average water table. Gilmore et al. (1991) provides hydrographs for well $199-\mathrm{N}-8 \mathrm{~S}$ and the Columbia River at the $100 \mathrm{~N}$ Area, slightly upstream from well 199-N-8S. Well 199-N-8S generally has a higher head than the river, except during times of high river level, when the gradient is reversed (Hartman and Lindsey 1993).

\subsection{N Springs. Riverbank springs in the $100 \mathrm{~N}$ Area are known as} "N Springs." The springs are a series of groundwater seeps and springs along the shore of the Coiumbia River opposite the 1301-N and 1325-N LWDF. The volume of water flowing from the springs has decreased in recent years because the water table in the $100 \mathrm{~N}$ Area has lowered with decreased wastewater discharge. The volume and chemistry of spring discharge also depends on the stage of the Columbia River. When the river stage is high, river water flows into the river bank. When the river stage drops, the springs discharge is similar to river water in composition for a time. Gradually the discharge becomes more "groundwater like" as it continues to flow. Spring discharge is also influenced by changes in waste discharge in the $100 \mathrm{~N}$ Area. Many springs that were active when large volumes of 
effluent were being discharged have decrease in volume or dried up altogether (Hartman and Lindsey 1993).

Dirkes (1992) compiled an annotated bibliography of studies that involved sampling Columbia River sediments, springs, or dose rates. Few of the studies compiled contain data specific to the $100 \mathrm{~N}$ Area. Routine sampling of the N Springs has been conducted in support of a National Pollutant Discharge Elimination System (NPDES) permit and DOE Order 5400.1 (to monitor radiological releases) (Rokkan 1988, Perkins 1989). Another sampling project was conducted along the river at the 100 Area in 1991 (DOE-RL 1992a, Peterson and Johnson 1992). These reports incorporated the results of previous investigations (Buske and Josephson 1988, McCormack and Carlile 1984, and Dirkes 1990).

Routine sampling of N Springs for the NPDES permit include three components: (1) seep spots; (2) seep wells; and (3) well N-8T. Seep spots are areas where water flows out of the river bank. Samplers sometimes dig out an area near seep spots to collect a sample. Many of the seep spots have dried up in recent years probably due to the stopping of wastewater discharges at 1301-N and 1325-N LWDF. Access is also limited to times when the river stage is low. There are 13 seep wells in the $100 \mathrm{~N}$ Area. These are very shallow wells in the river bank. Well N-8T is approximately $50 \mathrm{ft}(15 \mathrm{~m})$ from the Columbia River. It is screened between 20 to $30 \mathrm{ft}(6$ to $9 \mathrm{~m})$ in depth, approximately $5 \mathrm{ft}(1.5 \mathrm{~m})$ below the average water table. The well is sampled weekly with a composite sampler. It is used to represent the quality of groundwater flowing out to the river from the $\mathrm{N}$ Springs for the NPDES permit. Concentrations of radionuclides from $\mathrm{N}-8 \mathrm{~T}$ are slightly higher than at $\mathrm{N}$ Springs for most constituents, so the well provides a conservative estimate of radiological releases to the river (Perkins 1989).

2.1.7.3 Ringold Confined Aquifers. The existence of the Ringold confined aquifer system beneath the $100 \mathrm{~N}$ Area is inferred on the basis of geologic interpretation and limited borehole data from the surrounding area. Lithologic and stratigraphic data suggest that a system of confined aquifers and aquitards underlies the unconfined aquifer. The members of this aquifer system are listed below, shallowest to deepest (see Figure 2-2):

- $\quad$ Continuous interbedded clay, silt, and sand, approximately $200 \mathrm{ft}(60 \mathrm{~m})$ thick--this interval corresponds to the paleosol/overbank interval between units $\mathrm{E}$ and $\mathrm{B}$. It is believed to be an aquitard, forming the base of the unconfined aquifer; however thin sand layers are present within the unit, as observed at well 199-N-80. Fluvial sand unit $C$ is also present in this interval. It is thin and silty and probably is not a significant aquifer.

- $\quad$ Silty to clayey sand, approximately 80 to $100 \mathrm{ft}(24$ to $30 \mathrm{~m})$ thick--this interval corresponds to unit $B$ and may act as an aquifer.

- Laminated deposits of clay and silt, approximately $130 \mathrm{ft}(39 \mathrm{~m})$ thick--this interval corresponds to the lower mud unit. These sediments probably have very low permeability and are thought to act as an aquitard. 
- Gravel (indurated), approximately $20 \mathrm{ft}(6 \mathrm{~m})$ thick--this interval corresponds to unit $\mathrm{A}$, and lies over the Columbia River Basalt. It may act as an aquifer.

Well 199-N-80 was installed in 1992. It penetrates $16 \mathrm{ft}(4.8 \mathrm{~m})$ of clay and is completed in a $5 \mathrm{ft}(1.5 \mathrm{~m})$ thick layer of sand within a thick paleosol/overbank interval. The sand layer may act as a thin, confined aquifer. The borehole reached another clay unit beneath the sand. Well 199-N-8P was installed in 1966 and is completed within the paleosol/overbank interval (Hartman and Lindsey 1993).

There are recent data on vertical gradients between the uppermost aquifer and deeper units in the $100 \mathrm{~N}$ Area from well 199-N-80. The well is not located immediately adjacent to a shallow well, but it is near to and cross-gradient from well 199-N-75. The wells are located near the river. Since this is an area of grouridwater discharge most of the year, one would expect to find an upward gradient in the upper alquifer system. However, there seems to be a downward gradient near these wells through most of the year (Hartman and Lindsey 1993).

There appears to be an upward gradient immediately adjacent to the river. Two wells, 199-N-8S and 199-N-8P, are located approximately $10 \mathrm{ft}(3 \mathrm{~m})$ apart. Well 199-N-8S is completed approximately $15 \mathrm{ft}(4.5 \mathrm{~m})$ below the average water table. Well $199-\mathrm{N}-8 \mathrm{P}$ is completed in the paleosol/overbank deposit. Water levels in the deeper well are commonly 0.3 to $0.7 \mathrm{~m}$ ( 1 to $2 \mathrm{ft}$ ) higher than in the unconfined aquifer, indicating an upward gradient (Hartman and Lindsey 1993).

\subsubsection{Biological Resources}

Biological resources that are likely to be present at the ERA site have been divided into the following categories: vegetation, wildlife, threatened and endangered species, and sensitive or critical habitats. Each of these is discussed below.

2.1.7.1 Vegetation. The Hanford Site has been botanically characterized as shrub-steppe (Daubenmire 1970). The characteristic plant communities present in the 100 Area are cheatgrass-tumble mustard, sagebrush/cheatgrass or Sandberg's bluegrass,

sagebrush-bitterbrush/cheatgrass, and willow-riparian vegetation near the Columbia River shoreline (Cushing 1991). Cheatgrass is prevalent in the 100 Area because of the extensive perturbation of the soils in the area.

Plants likely to be present in the 100 Area include gray rabbit brush (Chrysothamnus nauseosus), cheatgrass (Bromus tectorum), tumbleweed (Salsola kali), yarrow (Achillea millefolium), yellow salsify (Tragopogon dubius), false yarrow (Chaenactis douglasii), and tumble mustard (Sisymbrium altissimum) (Cushing 1991, DOE-RL 1991b).

2.1.7.2 Wildlife. Of the approximately 39 species of mammals that have been recorded at the Hanford Site, most are small and nocturnal. The Great Basin pocket mouse (Perognathus parvus) is the most common. Muskrats (Ondatra zibethicus) and porcupines (Erithizon dorsatum) have been observed along the shorelines of streams, ponds, and ditches; beavers 
(Castor canadensis) occupy the sloughs along the Columbia River (Cushing 1991). Mule deer (Odocoileus hemionus) and raccoons (Procyon lotor) are also found or are likely to exist along the Columbia River.

Approximately 187 species of birds have been observed on the Hanford Site (Cushing 1991). The horned lark (Eremophila alpestris) and western meadowlark (Sturnella neglecta) are the most abundant nesting birds in the shrub-steppe vegetation type. Chinese ring-necked pheasants (Phasianus colchicus) and California quail (Callipepla californicus) are likely to be found near the Columbia River (Cushing 1991). The Columbia River provides a major nesting area for migrant waterfowl, such as ducks and geese. The most important resident waterfowl is the Canada goose (Branta canadensis moffitti), which rests on the islands of the river. The Hanford Site is located in the Pacific Flyway for migrating bird species; in addition, a major sandhill crane flyway passes over the site (Cushing 1991).

Twelve species of reptiles and amphibians are known to occur on the Hanford Site (Cushing 1991). The side-blotched lizard (Uta stansburiana) is the most abundant reptile found at the site. Toads (family: Bufonidae) and frogs (family: Ranidae) are found along the Columbia River (DOE-RL 1991b).

Of the 44 species of fish that have been identified in the Hanford Reach of the Columbia River, four species use the river as a migration route to and from upstream spawning areas: the chinook salmon (Oncorhyncus tshawytscha), sockeye salmon (oncorhyncus nerka), coho salmon (Oncorhyncus kisutch), and steelhead trout (Oncorhyncus mykiss). A fifth anadromous species, the shad (Alosa sapidissima), may also use the Hanford Reach to spawn (Cushing 1991).

2.1.7.3 Threatened and Endangered Species. Four species of plants that are listed by the federal government as candidate threatened or endangered species and by the State of Washington as either threatened or endangered could be present in the 100 Area:

- $\quad$ Persistentsepal yellowcress (Rorippa columbiae): endangered (state), candidate (federal)

- Northern Wormwood (Artemisia campestris ssp. borealis var. wormskioldii): endangered (State), candidate (federal)

- Columbia milk-vetch (Astragalus columbianus): threatened (state), candidate (federal)

- Hoover's desert parsley (Lomatium tuberosum): threatened (state), candidate (federal).

To date, none of these species has been reported as occurring in the $100 \mathrm{~N}$ Area (Cushing 1991, Sackschewsky 1992, and DOE-RL 1992b). 
There are several species of birds that are listed by either the federal government or the state of Washington as threatened or endangered that could occur as migrants within the 100 Area:

- Aleutian Canada goose (Branta canadensis leucopareia): endangered (federal and state)

- $\quad$ Peregrine falcon (Falco peregrinus): endangered (federal and state)

- $\quad$ Bald eagle (Haliaeetus leucocephalus): threatened (federal and state)

- White pelican (Pelecanus erythrorhychos): endangered (state)

- Sandhill crane (Grus canadensis): threatened (state)

- $\quad$ Ferruginous hawk (Buteo regalis): threatened (state).

None of these species is known to nest or roost in the $100 \mathrm{~N}$ Area (Cushing, 1991). However, bald eagle roosting locations exist at the $100 \mathrm{D}$ and $100 \mathrm{~K}$ Areas, and nesting sites have been observed near the $100 \mathrm{~F}$ Area (Fitzner and Weiss 1992).

One threatened mammal species, the pygmy rabbit (Sylvilagus idahoensis), was once known to exist west of the 200 Area but has not been observed in the 100 Area (DOE-RL 1992b).

2.1.7.4 Sensitive or Critical Habitat. Biological surveys conducted in 1991 and 1992 did not identify any sensitive or critical habitat (habitat that is essential to the support or continuance of a threatened or endangered species) in the area of the proposed ERA (Sackschewsky 1992).

Wetlands habitat exists in the riparian zone that borders the Columbia River. The riparian zone supports stands of willows, grasses, aquatic macrophytes, and other plants. The wetlands along the river are impacted by seasonal and dam-controlled fluctuations in water level.

Some alternatives developed as part of this ERA have assumed placement of the alternative to avoid impact to the 100-year floodplain. The 100-year floodplain was estimated using a discharge for the river of $440,000 \mathrm{ft}^{3} / \mathrm{sec}\left(12,500 \mathrm{~m}^{3} / \mathrm{sec}\right)$. This is the most recent Corps of Engineers estimate for events in the Hanford Reach. This flowrate would result in a zone of flooding to approximately $392 \mathrm{ft}(120 \mathrm{~m})$ amsl. The actual placement of the removal system affects both the effectiveness and the cost of the alternative. Factors to be considered include the topography and subsequent surface preparation for system installation, depth to the confining layer, equipment mobility and stability, as low as reasonably achievable (ALARA) practices (area near the river is designated as a radiation zone), legal considerations, and amount of residual contamination in the zone between the removal system and the river. These factors will be more fully analyzed in the design phase of the ERA. 


\subsubsection{Cultural Resources}

The Hanford Site contains numerous, well-preserved archaeological sites representing both the prehistoric and historic periods. The Hanford Reach has been occupied by Native Americans for more than 10,000 years. The river shores contain extensive archaeological deposits (Chatters 1989).

The following Indian tribes have dwelt along or utilized the Hanford Reach for fishing:

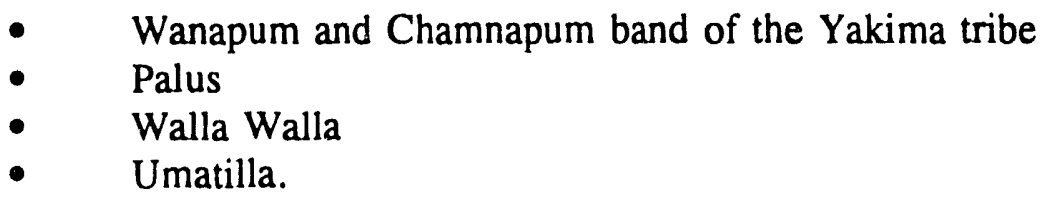

Certain landmarks on the Hanford Site, including sites and cemeteries along the Columbia River, are sacred to the Native Americans. Also, certain plant resources that are used in ceremonial activities may be present on the Hanford Site.

Historic resources dating from the 1860's and later at the Hanford Site are represented by remains of homesteads, farm fields, ranches, abandoned U.S. Army installations, gold mine tailings, and the following recorded historic locations (Cushing 1991):

- $\quad$ Allard Pumping Station at Coyote Rapids

- Hanford Irrigation Ditch

- Hanford townsite

- Wahluke Ferry

- White Bluffs townsite

- $\quad$ Richmond Ferry

- Arrowsmith townsite

- $\quad$ East White Bluffs ferry landing

- White Bluffs road

- Old Hanford High School

- Cobblestone Warehouse at Riverland.

The most recent historic sites are the defense reactors and materials processing facilities that have been constructed since World War II.

The $100 \mathrm{~N}$ Area is situated on an archaeologically rich segment of the Columbia River shoreline. Within $1.2 \mathrm{mi}(2 \mathrm{~km})$ of the area perimeter on the south bank are five recorded sites. Two pithouse village sites and a cemetery comprise the Ryegrass Archaeological District. A fourth site is part of the Hanford Generating Plant Site. All of the sites are either listed in or considered eligible for inclusion in the National Register of Historic Places (Chatters et al. 1990). In addition, two other cairn (or rock pile) sites have been recorded in the upland area east of $\mathrm{N}$ Springs. These two sites are considered to be at risk from CERCLA characterization studies (Chatters et al. 1992). 
The double-fenced compound of the $100 \mathrm{~N}$ Area has been investigated and cleared of cultural resources concerns (Cushing 1991). This means that no known sites of Native American religious or ceremonial significance, or sites included in the National Register of Historic Places, exist within the compound itself. No sitcs have been recorded along the stretch of riverbank adjacent to the N Springs.

In preparation for this ERA, a cultural resources review was conducted for the $\mathrm{N}$ Springs area. The Hanford Cultural Resources Laboratory (HCRL) found no cultural resources in the proposed project area and gave the site a clearance number (Hanford Cultural Resources Clearance [HCRC] \$92-100-032).

\subsubsection{Visual Resources}

The landscape in the vicinity of the Hanford Site is generally flat with little relief. Rattlesnake Mountain, Gable Mountain, and Gable Butte are the highest landforms within the site. The White Bluffs above the northern boundary of the river are a striking feature of the landscape. The Columbia River, flowing adjacent to the $100 \mathrm{~N}$ Area, provides a visual source of enjoyment to people. Also, desert flowers blooming in the spring provide an aesthetically pleasing resource (Cushing 1991).

The ERA site is adjacent to the Columbia River. The terrace slopes to the east of the $\mathrm{N}$ Springs range up to $460 \mathrm{ft}(140 \mathrm{~m})$ high. While the $100 \mathrm{~N}$ compound itself might not be considered a pleasing visual resource, the combined aspects of river and plateau downstream from the compound could be considered a source of visual enjoyment.

\subsubsection{Land and Water Use}

The entire Hanford Site has been designated a National Environmental Research Park (NERP) (Cushing 1991). The 100 Area in general, and particularly the $100 \mathrm{~N}$ Area, are not open for use by the public. Land use at the $\mathrm{N}$ Springs site along the river is negligible. The majority of any current land use would probably be associated with $100 \mathrm{~N}$ Area operations and with environmental monitoring and characterization activities.

The Columbia River is a source of recreational opportunity, especially on the lakes formed by the dams. Because the reach adjacent to the $100 \mathrm{~N}$ Area is free-flowing and relatively swift, the recreational use of the river would be limited to adequate power boating, hunting, and fishing, where permitted.

\subsection{NATURE AND EXTENT OF CONTAMINATION}

A detailed description of the sources, occurrence, and concentration of contaminants at the N Springs ERA site is presented below. 


\subsubsection{Sources}

The two major sources for the contamination released in the $\mathrm{N}$ Springs area are the 1301-N and 1325-N LWDF, consisting of cribs and their associated trenches. These cribs are discussed below.

\subsubsection{1301-N (116-N-1) Liquid Waste Disposal Facility. The 1301-N crib and trench were used between 1964 and 1985 for disposal of liquids from the operation of the $100 \mathrm{~N}$ Reactor. The facility made use of the natural filtration and adsorptive properties of the soil to remove the radioactive constituents from the discharged water. The crib is $290 \mathrm{ft}$ $(88 \mathrm{~m})$ long, $125 \mathrm{ft}(38 \mathrm{~m})$ wide, and approximately $12 \mathrm{ft}(3.7 \mathrm{~m})$ deep. The walls of the crib are sloped and covered with soil and gravel. A 3-ft (1-m) layer of boulders was placed in the crib. The zig-zag shaped extension trench extends for $1,600 \mathrm{ft}(490 \mathrm{~m})$ and is $50 \mathrm{ft}$ $(15 \mathrm{~m})$ wide and $12 \mathrm{ft}(3.7 \mathrm{~m})$ deep. Precast concrete panels were placed over the crib and trench to minimize wildlife access and airborne contamination (DOE-RL 1992b).}

The liquid wastes disposed to the $1301-\mathrm{N}$ crib and trench were generated from the reactor coolant system, spent fuel storage basin, periphery coolant systems, laboratories, and radioactive drain systems in the reactor facility. The average flow rate to the facility was $2,100 \mathrm{gal} / \mathrm{min}(7,900 \mathrm{~L} / \mathrm{min})$ during reactor operations (DOE-RL 1992b).

The cumulative inventory (accounting for decay as of January 1988) of selected radionuclides disposed to the crib and trench is presented in Table 2-1. Table 2-1 also lists the dangerous wastes disposed to the facility. Tritium and strontium-90 discharges to the 1301-N LWDF through 1990 are listed on Table 2-2. Tritium concentrations in the groundwater are discussed in Section 2.2.3.

The 1301-N crib and trench is currently classified as a Resource Conservation and Recovery Act (RCRA) interim status dangerous waste disposal facility. The DOE prepared a draft closure and post-closure plan (WHC 1987a) for submittal to the Washington State Department of Ecology (Ecology). A new closure and post-closure plan is to be submitted in May 1994, in accordance with milestone M-20-31 of the Tri-Party Agreement (Ecology et al. 1990).

The EPA issued a NPDES permit for the 1301-N facility. The permit requires routine monitoring of discharges to the Columbia River by way of $N$ Springs. The monitoring results are discussed in Section 2.2.4.

\subsubsection{1325-N (116-N-3) Liquid Waste Disposal Facility. The 1325-N LWDF was} constructed as a replacement for the 1301-N LWDF and first received liquid wastes from $\mathrm{N}$ Reactor in 1983. Between 1983 and September 1985, both facilities received N Reactor wastes. In September 1985, all flow was diverted to the $1325-\mathrm{N}$ facility. The crib is $250 \mathrm{ft}$ $(76 \mathrm{~m})$ long, $240 \mathrm{ft}(73 \mathrm{~m})$ wide, and provides $60,000 \mathrm{ft}^{2}\left(5,600 \mathrm{~m}^{2}\right)$ of percolation area. A $3,000 \mathrm{ft}(910 \mathrm{~m})$ extension trench was constructed to provide additional operating capacity. The trench is $55 \mathrm{ft}(17 \mathrm{~m})$ wide and $7 \mathrm{ft}(2 \mathrm{~m})$ deep and is covered by precast concrete panels to prevent access by wildlife (DOE-RL 1992b). 
The liquid wastes disposed to the $1325-\mathrm{N}$ crib and trench were the same as those disposed to $1301-\mathrm{N}$. The average flow rate to the $1325-\mathrm{N}$ facility was $450 \mathrm{gal} / \mathrm{min}$ $(1,700 \mathrm{~L} / \mathrm{min})$ (Connelly et al. 1991).

The cumulative inventory disposed to the $1325-\mathrm{N}$ facility, accounting for decay through September 1985, is listed on Table 2-3. This table also lists an estimate of dangerous wastes disposed to the facility. Tritium and strontium-90 discharges to the $1.325-\mathrm{N}$ LWDF through 1990 are listed on Table 2-2. Major discharges were discontinued to this facility in January 1987 when the N Reactor was placed on standby. Small discharges continued until 1991. The crib and trench are not currently receiving any liquid wastes; no discharges are expected in the future. When operations at the $\mathrm{N}$ Reactor were discontinued, the 1325 LWDF was put in a standby condition to be used for reactor shutdown operations. However, the facility has subsequently been removed from service and will not be used for reactor shutdown.

The 1325-N LWDF is a RCRA interim status waste disposal facility. As with the 1301-N LWDF, a closure and post-closure plan was prepared by DOE (WHC 1987b) and submitted to Ecology. A new closure and post-closure plan is to be submitted in May 1994, according to the Tri-Party Agreement Milestone M-20-31 (Ecology et al. 1990).

\subsubsection{Soil Contaminants}

Soil contamination resulted from N Reactor liquids being disposed to the $1301-\mathrm{N}$ and 1325-N L.WDF. As the liquids traveled through the vadose zone, radioactive contaminants sorbed onto the soils beneath the LWDF. Retention of radionuclides in the soils is highly variable, ranging from nearly complete retention for cesium-137 to no retention for tritium. Strontium-90 retention is intermediate between these two.

Robertson et al. (1984) conducted a study to determine the migration of radionuclides from the 1301-N LWDF to the N Springs. In this study, wells 199-N-9, 199-N-12, and 199N-13 were installed to the water table, north of the 1301-N LWDF at distances of approximately 100,150 , and $240 \mathrm{ft}(30,46$, and $73 \mathrm{~m})$. Drill cuttings were collected and analyzed for radionuclides. In addition, gamma ray logging tools were run in the wells. Results of the study showed that very low concentrations of radionuclides, such as cobalt- 60 , ruthenium-106, antimony-125, and cesium-137, were present in well $\mathrm{N}-9$ above the water table. The concentrations increased markedly at the water table. Wells $199-\mathrm{N}-12$ and $199-\mathrm{N}-13$ had lower concentrations in the unsaturated zone, but also had higher concentrations at the water table. This study indicates that extensive lateral migration of radionuclides from the LWDF within the vadose zone did not occur during the liquid disposal period. This study, which also addresses the selective removal of radionuclides in the soil column, concludes that the cationic and particulate species are retained in the soil column and the anionic and nonionic species are transported more freely to and within the groundwater. While this study did not address strontium-90 specifically, the results should also be indicative of strontium-90 concentrations in the area. With the cessation of liquid disposal, it is estimated that very high concentrations of radionuclides remain in the soil column between the surface and the groundwater. These contaminants are sorbed onto the 
soil and the only transport medium for these contaminants is the small amount of precipitation recharge which is occurring from 0.4 to $4 \mathrm{in} / \mathrm{yr}(1$ to $10 \mathrm{~cm} / \mathrm{yr})(\mathrm{Gee} 1987)$

Sediment samples were collected for chemical and radiological analysis during drilling of 4 wells in 1992 (Hartman 1993, WHC 1993). Three wells are near the 1301-N LWDF (199-N-75, 199-N-76, and 199-N-80); one is near the 1324-NA percolation pond (199-N-77). Metals concentrations were in the normal range for the Hanford Site. No significant concentrations of organic compounds were identified, except some vegetation-derived material in the upper vadose zone. There is evidence of radionuclide contamination in the vadose zone near the 1301-N LWDF. Cobalt-60 and strontium-90 were detected in the sediments between 50 and $75 \mathrm{ft}(15$ and $23 \mathrm{~m})$ in depth, an interval that straddles the current water table (Hartman and Lindsey 1993).

A spectral gamma ray borehole log was run in a number of wells and vadose borings in 1992 and 1993 (Price 1993a, 1993b). The logs were run through the permanent casing from surface to total depth (e.g., below the water table). In wells near the 1301-N LWDF (199-N-75, 199-N-76, and 199-N-80), cobalt-60 was detected between approximately 50 to $85 \mathrm{ft}(15$ to $26 \mathrm{~m})$ depth. The levels of cobalt -60 were similar to those detected by laboratory analyses (Hartman and Lindsey 1993). In wells near the 1325-N LWDF (199-N-27, 199-N-28, 199-N-29, 199-N-39, 199-N-44, and 199-N-70), cobalt-60 was detected between 50 and $90 \mathrm{ft}(15$ to $27 \mathrm{~m})$. No significant cesium-137, europium-152, or europium-154 were detected. A log of well 199-N-56, upgradient of the 1301-N LWDF, detected no cobalt- 60 or other man-made gamma-emitting radionuclides.

The vadose zone in the $100 \mathrm{~N}$ Area is contaminated with radionuclides including cobalt-60 and strontium-90 near the 1301-N and 1325-N LWDF, and with petroleum products from underground tanks and pipes near the $\mathrm{N}$ Reactor building. Vadose zone studies include field screening and laboratory analyses of samples collected during drilling, and borehole geophysical logging.

\subsubsection{Groundwater Contaminants}

Groundwater contamination within the N Springs area is primarily the result of liquid waste disposal to the 1301-N and 1325-N LWDF. Neither LWDF is in use any longer; discharges to $1301-\mathrm{N}$ and $1325-\mathrm{N}$ were halted in 1985 and 1991 respectively. As was stated in Section 2.2.1, many of the radionuclides disposed to these facilities have remained adsorbed to the soils and are found only in low concentrations in the groundwater. An example of this is cesium-137, where a combined inventory of $2,650 \mathrm{Ci}$ (decayed to 1985) have been disposed to the two LWDF and the maximum concentration in groundwater $(6.68 \mathrm{pCi} / 1$, well $199-\mathrm{N}-8 \mathrm{~S})$ is significantly below the DOE release limit of $120 \mathrm{pCi} / 1$. Concentrations of radionuclide in the groundwater are also affected by radioactive decay. Radioactive decay halflives for tritium and strontium-90 are 12.3 and 28.1 years respectively.

Representative groundwater analyses are listed in Table 2-4. Samples from these wells were collected during December 1991 and January 1992 as a part of the $1301-\mathrm{N}$ and 1325-N RCRA groundwater monitoring programs. 
The 1301-N and 1325-N LWDF are currently under RCRA indicator evaluation monitoring (detection monitoring) programs (Hartman 1993). Results from these monitoring programs indicate that no hazardous chemical constituents are present in the groundwater. Radionuclides, primarily tritium and strontium-90, are present in the groundwater at significant concentrations. Lesser amounts of other radionuclides are also present, but are below regulatory and DOE release limits. Concentration maps for tritium and strontium-90 are presented on Figures 2-6 through 2-9. Figures 2-6 and 2-7 are based on groundwater sampling conducted in February 1990. Figures 2-8 and 2-9 are based on sampling conducted in February 1993. Comparisons of Figures 2-6 and 2-8 indicate that strontium-90 concentrations have declined (between February 1990 and February/March 1993) near the 1325-N LWDF and have remained steady in the groundwater beneath the 1301-N LWDF. Exceptions to this are wells $\mathrm{N}-3$ and $\mathrm{N}-14$ where increases in strontium-90 are noted. Two new wells, N-75 and N-76 were installed in 1992 between the 1301-N LWDF and the Columbia River to supplement the RCRA groundwater monitoring program. It should be noted that there is approximately one order of magnitude difference in concentrations between these two wells. Both wells have been sampled three times and results are consistent. The reason for this is unknown but may be related to localized differences in the adsorptive and desorptive characteristics of the soils in the area. Tritium values for these wells do not show this large difference (Figure 2-9). The declining strontium-90 concentrations in the vicinity of the 1325-N LWDF may be due to the flushing of the saturated soils with noncontaminated groundwater, an overall lower inventory of strontium-90 in the soils, and, to a lesser extent, radioactive decay.

Hartman and Lindsey (1993) report that strontium-90 contamination in groundwater appears to be limited to the top of the unconfined aquifer. Wells screened at the water table (e.g., well $\mathrm{N}-67$ ) have orders of magnitude more strontium-90 than adjacent wells with screens set only 20 to $30 \mathrm{ft}(6$ to $9 \mathrm{~m}$ ) deeper (e.g., well $\mathrm{N}-69$ has no detectable strontium-90). This relationship is not present for tritium however. This suggests that strontium-90 may have sorbed to the sediments near the water table as the contaminated waste water moved downward under the gradient imposed by $1301-\mathrm{N}$ and $1325-\mathrm{N}$ groundwater mounds. Strontium-90 is not transported further down in the unconfined aquifer due to sorption to the sediments (Hartman and Lindsey 1993).

Figures 2-7 and 2-9 show that tritium concentrations overall have declined in the vicinity of the 1325-N LWDF and have remained steady near the 1301-N LWDF. An exception to this is at wells $\mathrm{N}-14$ and $\mathrm{N}-41$ where tritium concentrations have increased and at well N-3 where the concentration declined. Tritium is a nonretarded radionuclide and travels at the same rate as the groundwater. The groundwater flow direction is northerly except near the river as shown on Figures 2-4 and 2-5.

A sulfate plume is present along the western edge of the area. This plume is the result of discharge to the 1324-NA percolation pond. Sulfate is a nonregulated constituent. Hartman and Lindsey (1993) discuss the source and occurance of the sulfate plume in the 100 N Area. Based on the sulfate plume map, contained in Hartman and Lindsey (1993), the plume intersects the southwestern extent of the strontium- 90 plume in the N Springs ERA site. 
Diesel fuel and other petroleum products have been present on top of the water table beneath the $100 \mathrm{~N}$ Area since 1966 (Hartman and Lindsey 1993). The concentration appears to be fairly limited in extent. Wells surrounding the spill have been sampled and reported annually (e.g., Perkins 1992). The leaks and spills occurred near the $100 \mathrm{~N}$ Reactor building.

Water samples are collected annually from wells placed in adjacent springs and seeps which discharge to the river. Average results of these analyses for the period from 1985 to 1991 are shown on Figure 2-10. This figure illustrates that generally strontium-90 concentrations are declining with time. Exceptions are at well $\mathrm{N}-8 \mathrm{~T}$ and seep wells 3 and 4 which have maintained a more constant concentration. The most recent spring data available (PNL 1993) reports a strontium-90 concentration of approximately $11,000 \mathrm{pCi} / \mathrm{L}$. This is approximately 1.5 times higher than that measured during the previous six years. This may indicate that strontium- 90 concentrations are increasing at the springs. It should be noted that this is a different well being sampled than was used for previous sampling efforts.

Differences may be the result of different well completions and localized efforts or maybe a true increase in concentrations. 
DOE\RL-93-23, Rev. 0

Figure 2-1 Hanford Site

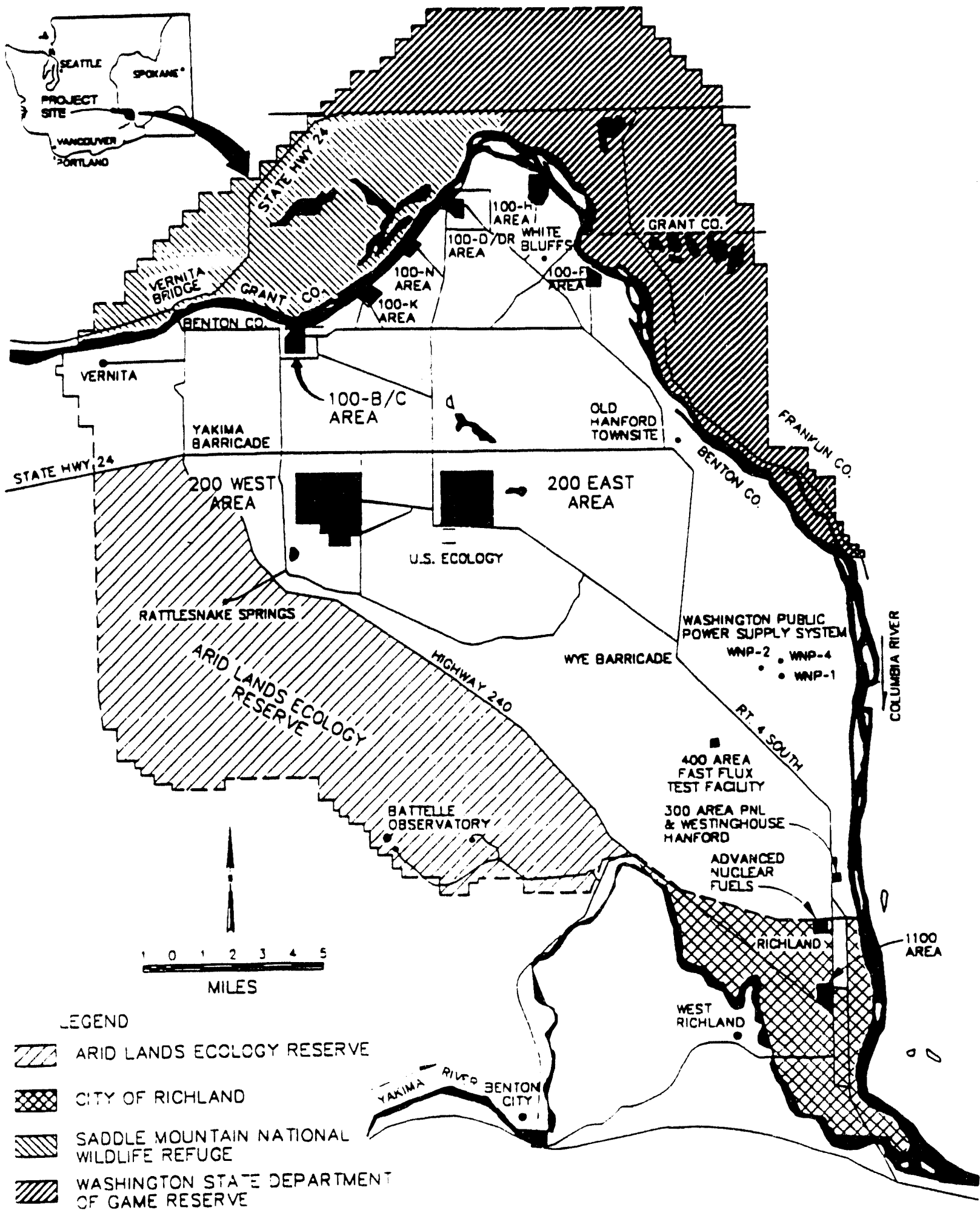




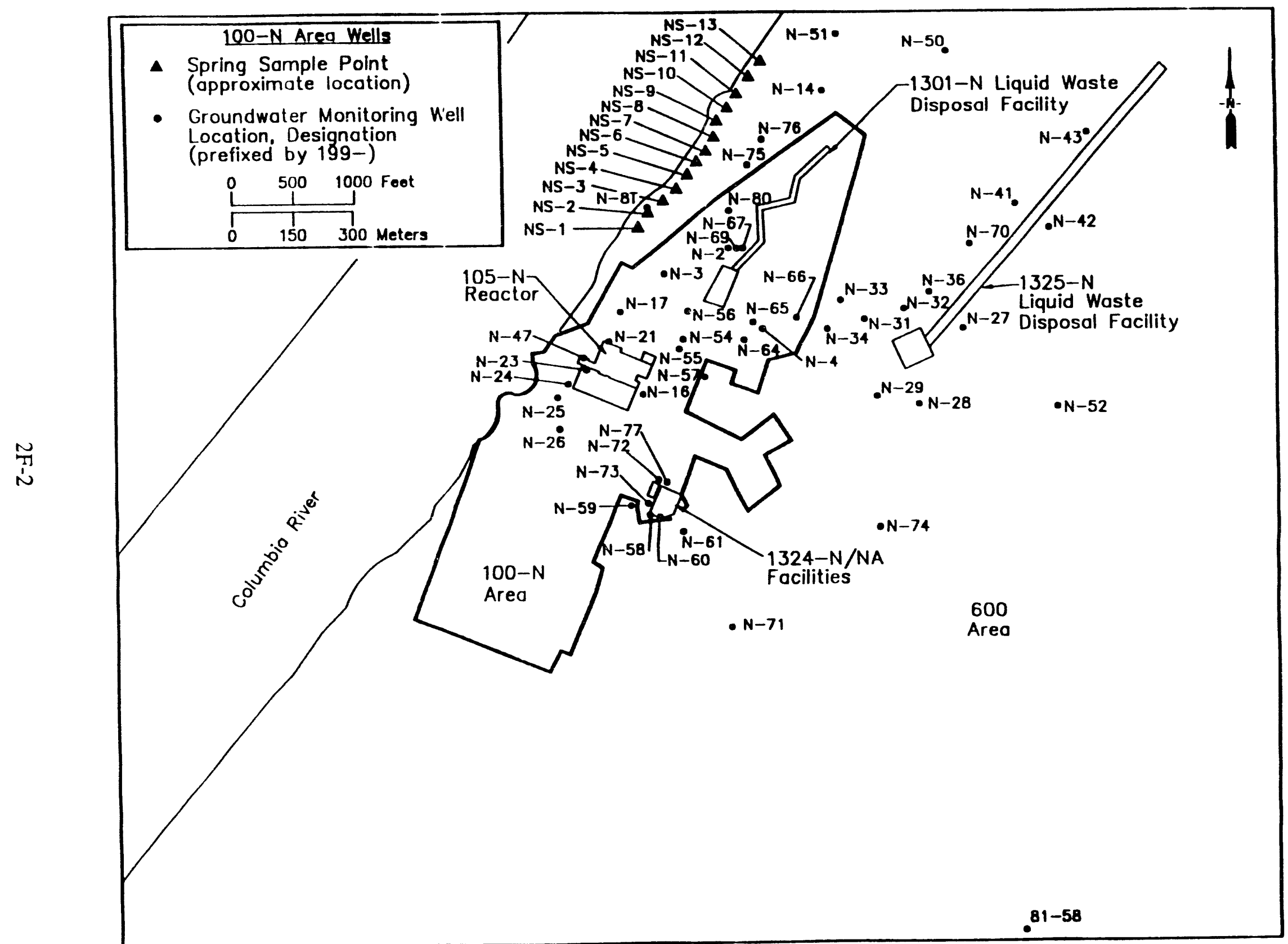

苟 
Figure 2-3 Conceptual Geologic and Hydrogeologic Column

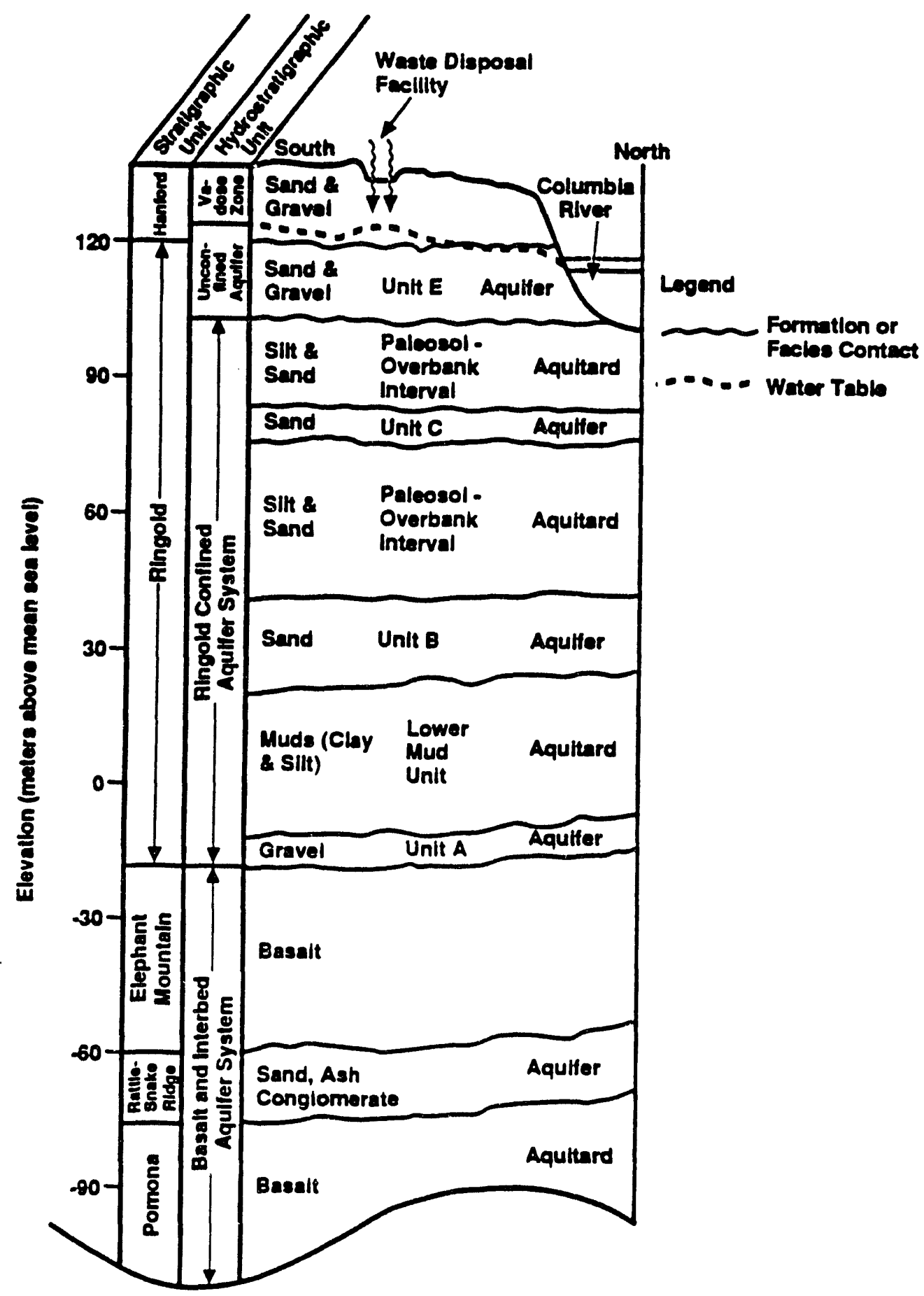

H2311008.1 


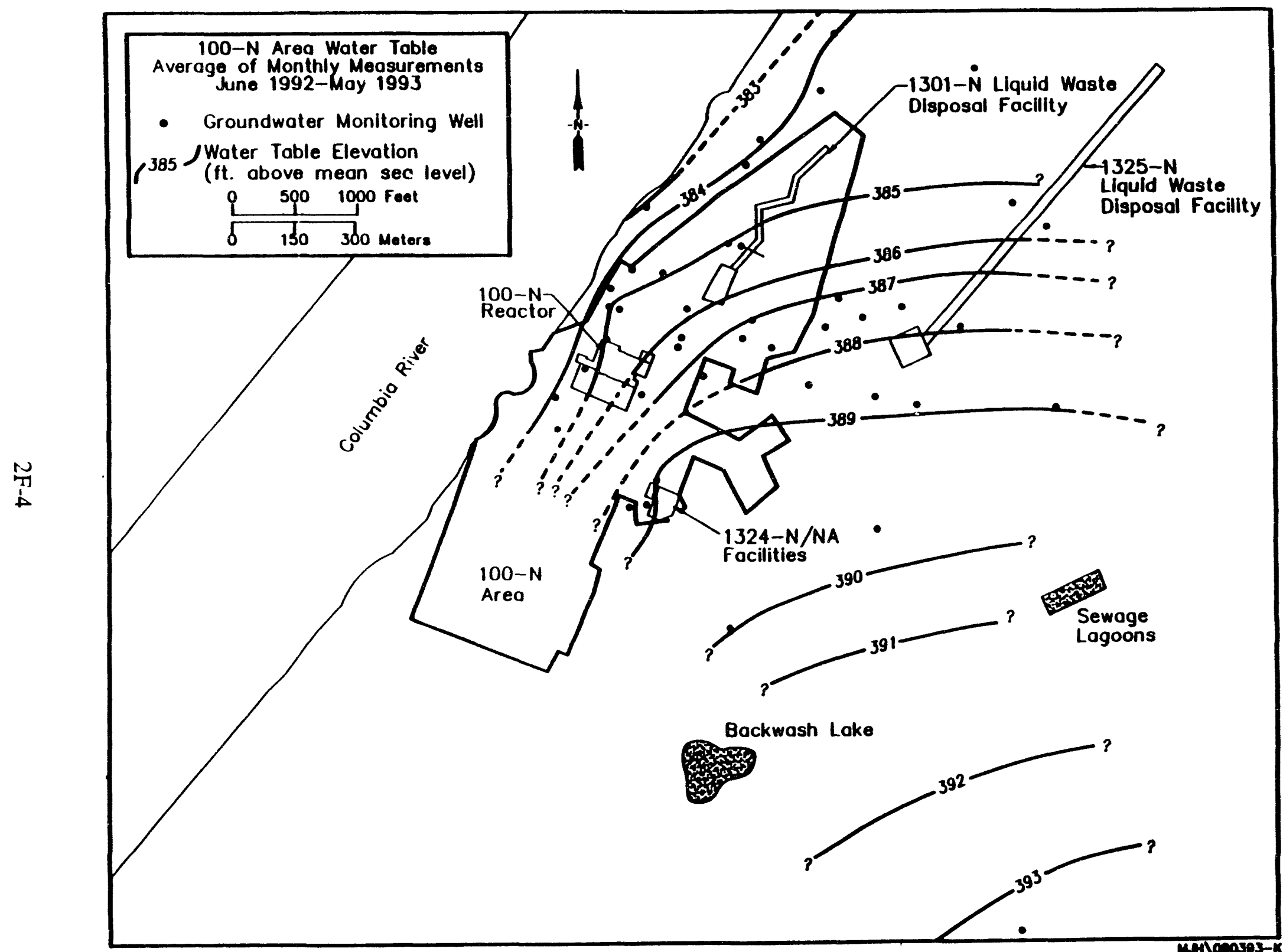

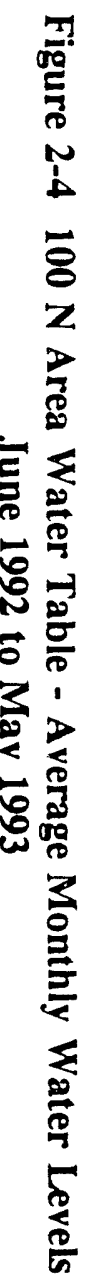




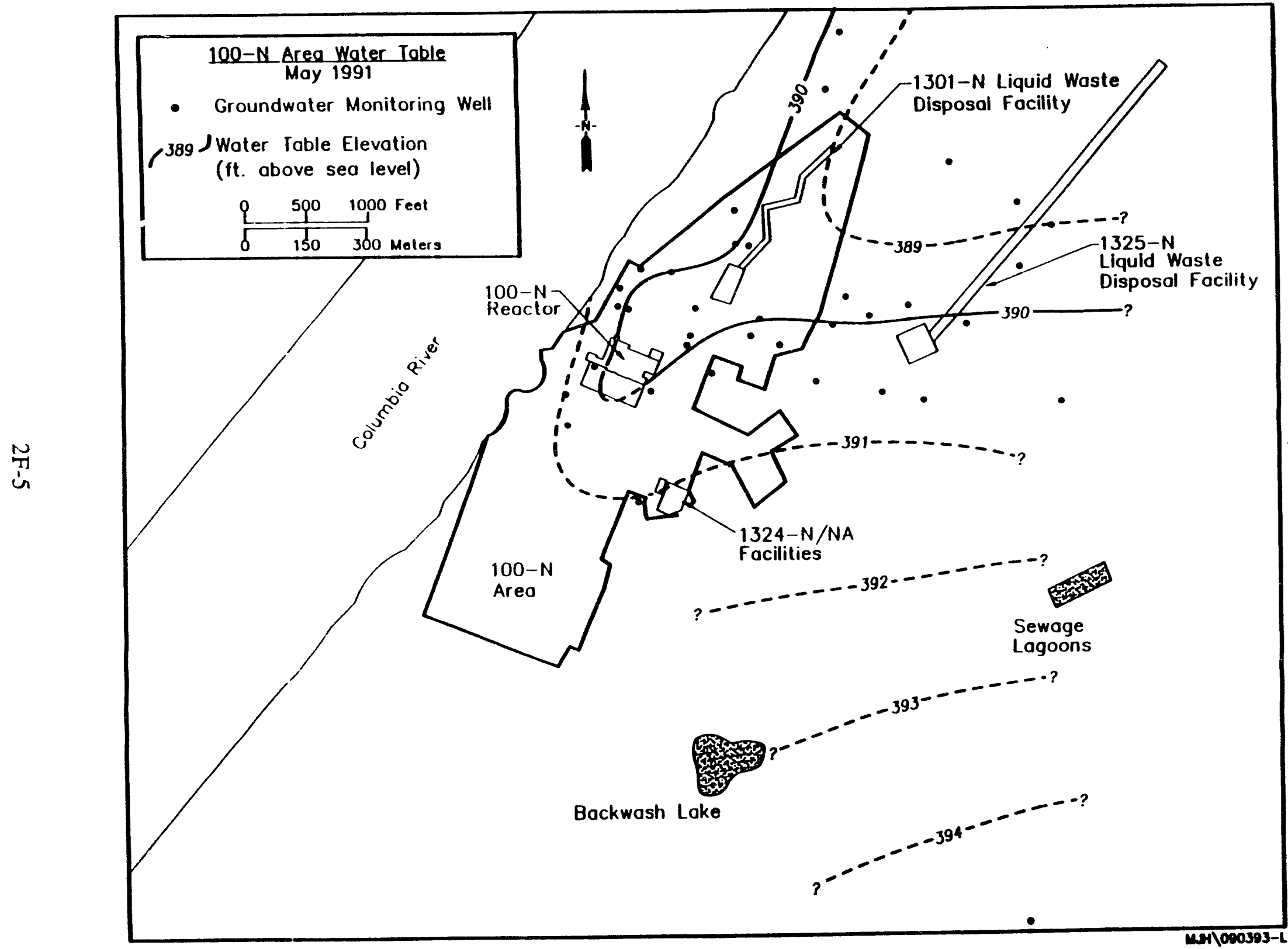

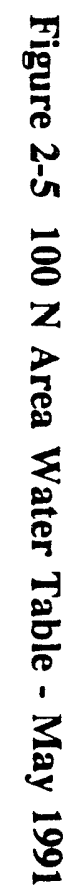

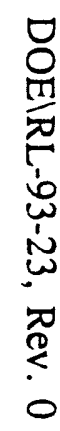




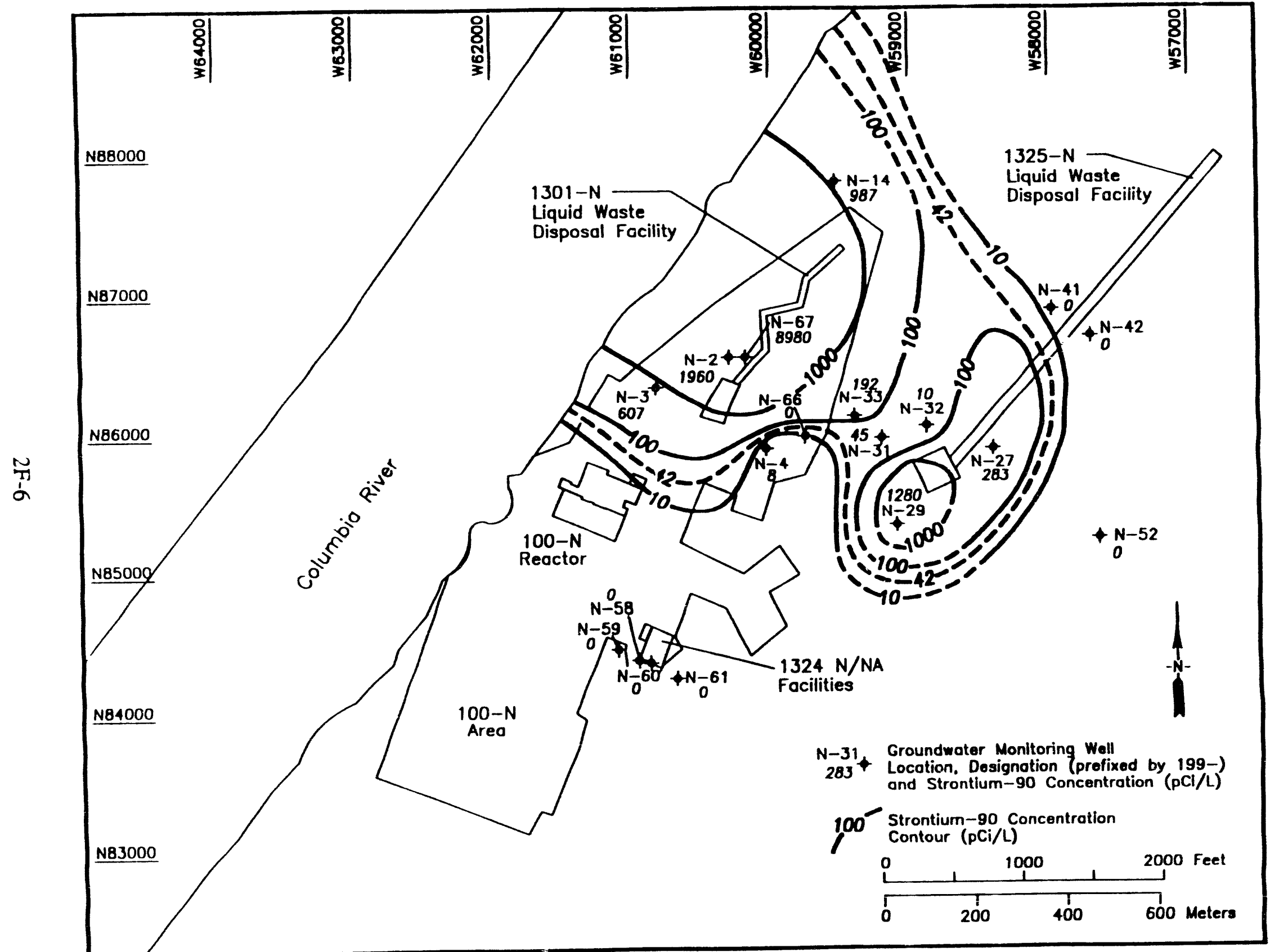

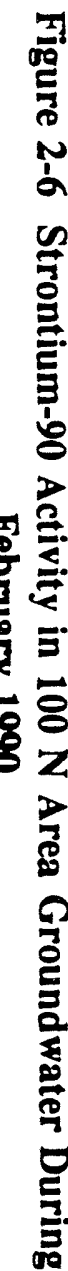




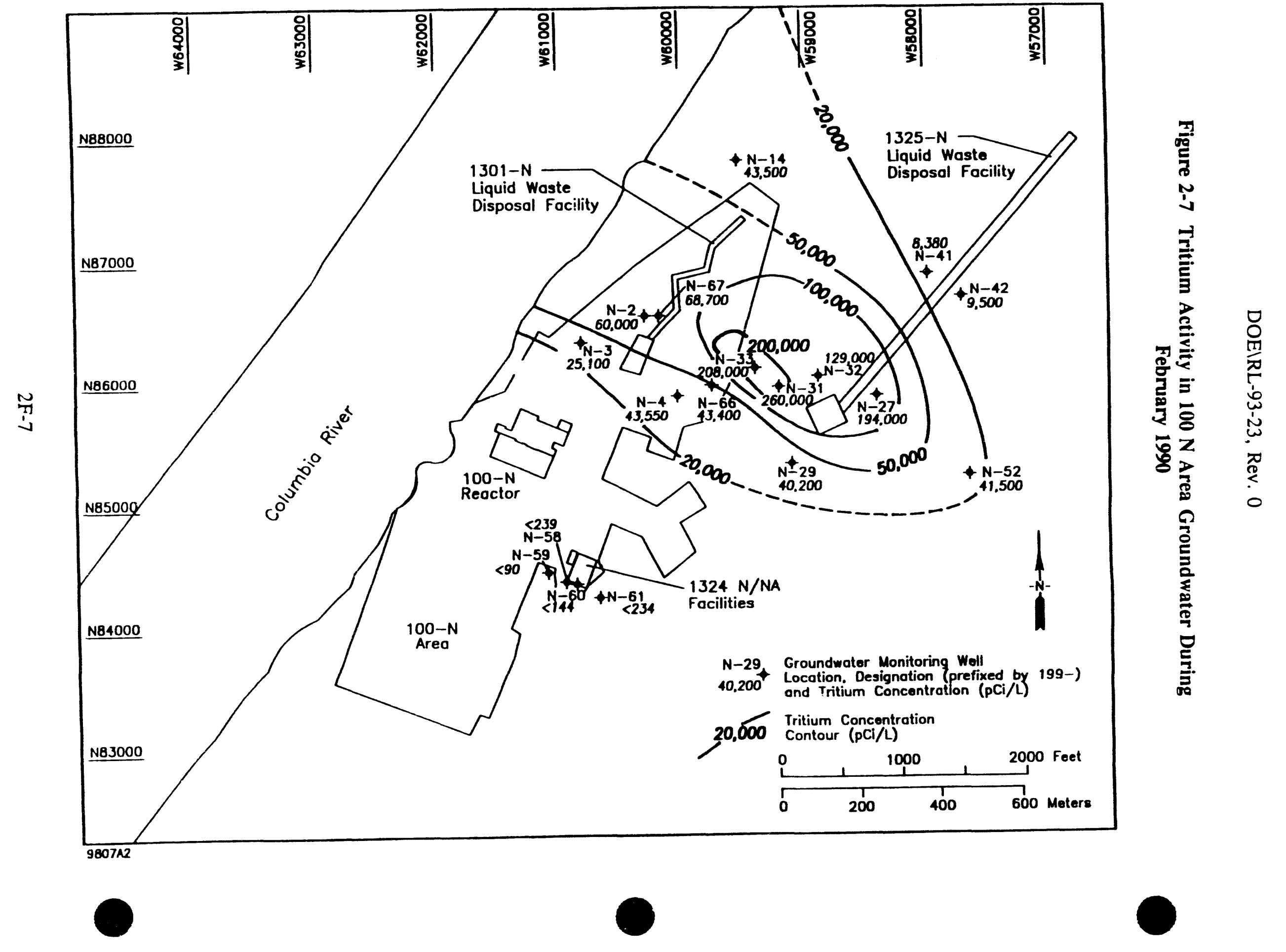



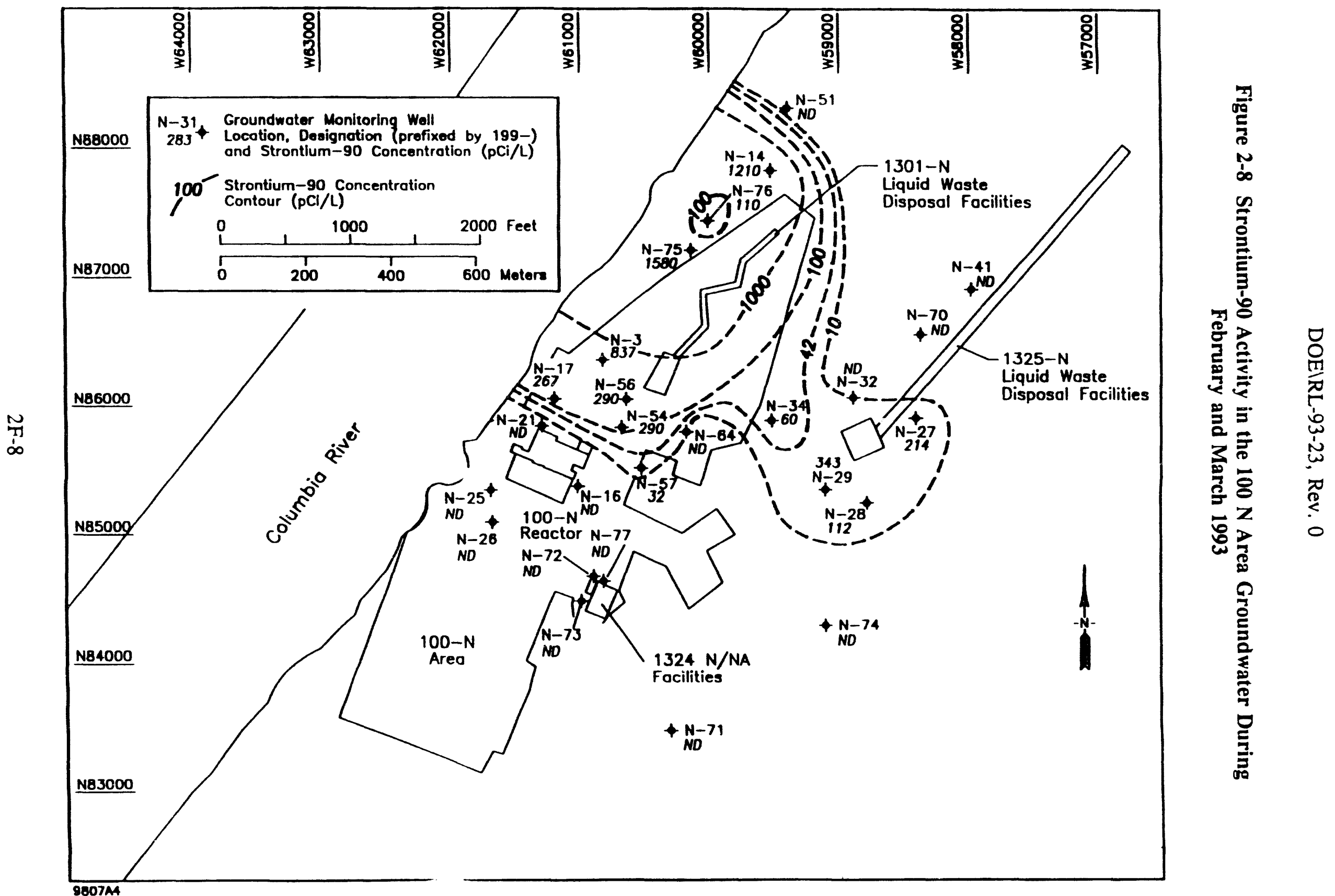


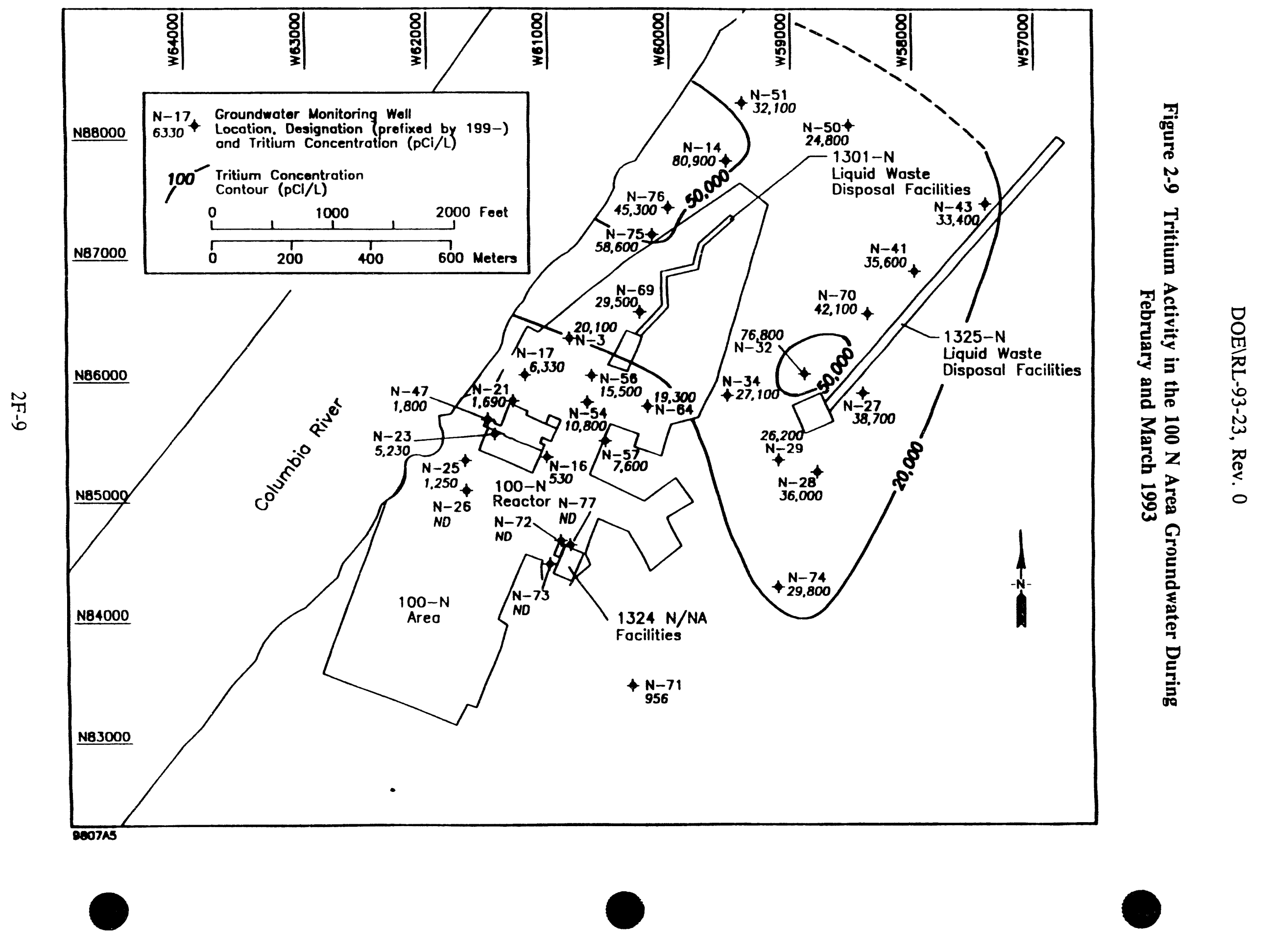


DOE\RL-93-23, Rev. 0

Figure 2-10 Average Strontium-90 Concentrations in the N Springs from 1985 to 1991

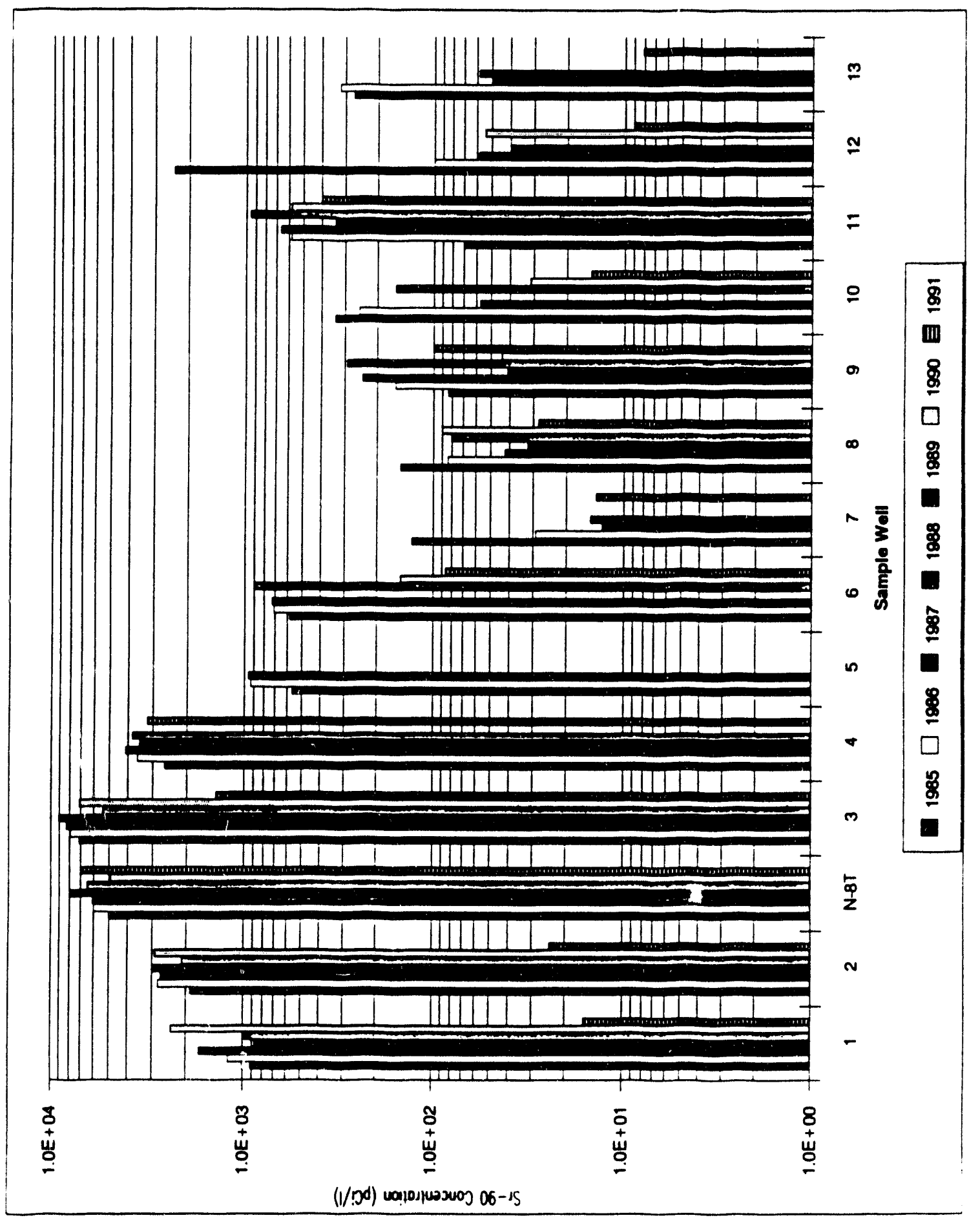


DOE\RL-93-23, Rev. 0

Table 2-1 Radionuclides/Chemical Wastes Disposed to 1301-N Liquid Waste Disposal Facility

\begin{tabular}{|c|c|}
\hline Radionuclide & Cumulative Inventory" (Ci) \\
\hline Tritium & 3,000 \\
\hline Cobalt- 60 & 3,800 \\
\hline Strontium-90 & 1,800 \\
\hline Ruthenium-106 & 120 \\
\hline Cesium-134 & 51 \\
\hline Cesium-137 & 2,300 \\
\hline Plutonium-239 & 18 \\
\hline Chemical Waste & Disposal Rate (lb/yr) \\
\hline Hydrazine Test Solution & 6,100 \\
\hline Ammonia Test Solution & 6,100 \\
\hline Chloride Test Solution & 7,800 \\
\hline Fluoride Test Solution & 3,900 \\
\hline Lead-Acetate Battery Fluid & $630^{b}$ \\
\hline Nickel-Cadmium Battery Fluid & $270^{b}$ \\
\hline Hydrazine (Injection System) & 350 \\
\hline \multicolumn{2}{|c|}{$\begin{array}{l}\text { Accounting for decay to September } 1985 \\
\text { Actual amount is not available, but amount shown is possible because of common } \\
\text { floor drains. } \\
\text { Sources: DOE-RL 1991b }\end{array}$} \\
\hline
\end{tabular}


Table 2-2 Water Flow Rates and Strontium-90 Discharges to 1301-N and 1325-N Liquid Waste Disposal Facilities

\begin{tabular}{|c|c|c|c|c|c|c|c|}
\hline Year & $\begin{array}{l}\text { Water Flow } \\
\text { to } 1301-N \\
\text { LWDF } \\
\text { (liters/day) }\end{array}$ & $\begin{array}{l}\text { Water Flow } \\
\text { to } 1325-N \\
\text { I.WDF } \\
\text { (liters'day) }\end{array}$ & $\begin{array}{l}\text { Average Sr-90 } \\
\text { Concentration in } \\
\text { Discharges } \\
\text { (pCi/liter) }\end{array}$ & $\begin{array}{c}\text { Annual } \\
\text { Sr-90 } \\
\text { Discharge } \\
\text { (Ci/year) }\end{array}$ & $\begin{array}{c}\text { Annual Sr-90 } \\
\text { Discharge } \\
\text { Accounting for } \\
\text { Decay } \\
\text { (Ci/year) } \\
\end{array}$ & $\begin{array}{l}\text { Annual } \\
\text { Tritium } \\
\text { Discharge } \\
\text { (Ci/year) }\end{array}$ & $\begin{array}{c}\text { Annual } \mathrm{H}-3 \\
\text { Discharge } \\
\text { Accounting for } \\
\text { Decay } \\
\text { (Ci/year) }^{2} \\
\end{array}$ \\
\hline $1964^{\prime}$ & $9,462,500$ & 0 & 20,000 & 69 & 35 & 288 & 60 \\
\hline $1965^{1}$ & $9,462,500$ & 0 & 20,000 & 69 & 36 & 288 & 63 \\
\hline $1966^{\prime}$ & $9,462,500$ & 0 & 20,000 & 69 & 37 & 288 & 67 \\
\hline $1967^{1}$ & $9,462,500$ & 0 & 20,000 & 69 & 38 & 288 & 71 \\
\hline $1968^{\prime}$ & $9,462,500$ & 0 & 20,000 & 69 & 39 & 288 & 75 \\
\hline $1969^{\prime}$ & $9,462,500$ & 0 & 20,000 & 69 & 40 & 288 & 79 \\
\hline $1970^{1}$ & $9,462,500$ & 0 & 20,000 & 69 & 41 & 288 & 84 \\
\hline $1971^{\prime}$ & $9,462,500$ & 0 & 20,000 & 69 & 42 & 288 & 88 \\
\hline $1972^{\prime}$ & $9,462,500$ & 0 & 20,000 & 69 & 43 & 288 & 94 \\
\hline 1973 & $8,702,000$ & 0 & 4,700 & 15 & 9 & 480 & 165 \\
\hline 1974 & $9,500,000$ & 0 & 18,100 & 63 & 41 & 190 & 69 \\
\hline 1975 & $9,500,000$ & 0 & 26,800 & 93 & 62 & 130 & 50 \\
\hline 1976 & $9,900,000$ & 0 & 30,400 & 110 & 75 & 350 & 142 \\
\hline 1977 & $14,500,500$ & 0 & 22.700 & 120 & 84 & 430 & 185 \\
\hline $19 / 8$ & $12,500,000$ & 0 & 26,300 & 120 & 85 & 330 & 150 \\
\hline 1979 & $13,500,000$ & 0 & 26,400 & 130 & 95 & 200 & 96 \\
\hline 1980 & $12,500,000$ & 0 & 35,000 & 160 & 119 & 88 & 45 \\
\hline 1981 & $10,500,000$ & 0 & 21,900 & 84 & 64 & 82 & 44 \\
\hline 1982 & $10,500,000$ & 0 & 36,500 & 140 & 110 & 360 & 205 \\
\hline 1983 & $6,942,000$ & $1,960,900$ & 43,500 & 141 & 114 & 180 & 109 \\
\hline 1984 & $8,100,000$ & $1,900,000$ & 84,800 & 310 & 255 & 140 & 89 \\
\hline 1985 & $7,200,000$ & $2,800,000$ & 65,700 & 240 & 202 & 270 & 182 \\
\hline 1986 & 0 & $7,250,000$ & 13,600 & 36 & 31 & 220 & 157 \\
\hline 1987 & 0 & $2,100,000$ & 19,600 & 15 & 13 & 98 & 74 \\
\hline 1988 & 0 & $1,660,000$ & 24,700 & 15 & 14 & 64 & 51 \\
\hline 1989 & 0 & $1,660,000$ & 46,000 & 28 & 26 & 74 & 63 \\
\hline 1990 & 0 & 548,000 & 69,000 & 14 & 13 & 38 & 34 \\
\hline Total & $9,954,864$ & $2,484,750$ & 29,470 & 2.454 & 1,760 & 6,316 & 2,591 \\
\hline Source: & \multicolumn{7}{|c|}{$\begin{array}{l}\text { Adapted from Connelly et al. } 1991 \text { and WHC 1991. Values for } 1989 \text { from Rokkan 1990, values for } 1990 \\
\text { from Manley and Diediker 1992. }\end{array}$} \\
\hline & \multicolumn{7}{|c|}{$\begin{array}{l}\text { No reliable data for average flow rates and average concentrations of effluents. Rough estimates based on } \\
\text { discharge volumes from } 1973 \text { to } 1976 \text { were used. Data for } 1973 \text { through } 1990 \text { are from yearly effluent } \\
\text { release reports. }\end{array}$} \\
\hline$=$ & \multicolumn{7}{|c|}{$\begin{array}{l}\text { Decay was accounted for through } 1992 \text { using the equation: } \\
\text { Conc. }=\mathrm{C} \text { exp }(-0.693 * \mathrm{~T} / \mathrm{t} / 2) \\
\text { where } \mathrm{C}=\text { initial activity }(\mathrm{Ci}), \mathrm{T}=\text { number of years since discharge, exp = exponential function } \\
\mathrm{t} 1 / 2=\mathrm{Sr}-90 \text { half life }=28.6 \mathrm{yrs} \text {, Tritium }=12.33 \text { yrs. }\end{array}$} \\
\hline
\end{tabular}


Table 2-3 Radionuclides and Chemical Wastes Disposed to 1325-N Liquid Waste Disposal Facility

\begin{tabular}{|c|c|}
\hline Radionuclide & Cumulative Inventory" (Ci) \\
\hline Tritium & 95 \\
\hline Cobalt -60 & 1,300 \\
\hline Strontium-90 & 200 \\
\hline Ruthenium-106 & 66 \\
\hline Cesium-134 & 14 \\
\hline Cesium-137 & 350 \\
\hline Plutonium-239 & 2.6 \\
\hline Chemical Waste & Disposal Rate (lb/yr) \\
\hline Hydrazine Test Solution & 6,100 \\
\hline Ammonia Test Solution & 6,100 \\
\hline Chloride Test Solution & 7,800 \\
\hline Fluoride Test Solution & 3,900 \\
\hline Lead-Acetate Battery Fluid & $120^{6}$ \\
\hline Nickel-Cadmium Battery Fluid & $80^{b}$ \\
\hline Hydrazine (Injection System) & 10 \\
\hline \multicolumn{2}{|c|}{$\begin{array}{l}\text { Accounting for decay to September } 1985 \\
\text { Actual amount is not available, but amount shown is possible because of common } \\
\text { floor drains. } \\
\text { Sources: DOE-RL } 1991 \mathrm{~b}\end{array}$} \\
\hline
\end{tabular}


DOE\RL-93-23, Rev. 0

Table 2-4 Groundwater Quality in the Vicinity of the N Springs ERA Site (Page 1 of 3)

\begin{tabular}{|c|c|c|c|c|c|}
\hline \multirow{2}{*}{ Constituent } & \multirow{2}{*}{ Units } & \multicolumn{2}{|c|}{ Well 199-N-2 } & \multicolumn{2}{|c|}{ Well 199-N-3 } \\
\hline & & Result & Error ${ }^{1}$ & Result & Error ${ }^{1}$ \\
\hline Ammonium ion & $\mathrm{ppb}$ & $40 \mathrm{U}$ & & $100 \mathrm{U}$ & \\
\hline Antimony & ppb & $200 \mathrm{U}$ & & & \\
\hline Antimony, filtered & ppb & $200 \mathrm{U}$ & & $200 \mathrm{U}$ & \\
\hline Arsenic & $\mathrm{ppb}$ & $5 \mathrm{U}, \mathrm{H}$ & & $5 \mathrm{U}, \mathrm{H}$ & \\
\hline Arsenic, filtered & $\mathrm{ppb}$ & $5 \mathrm{U}, \mathrm{H}$ & & $5 \mathrm{U}, \mathrm{H}$ & \\
\hline Barium & ppb & 29 & & & \\
\hline Barium, filtered & $\mathrm{ppb}$ & $20 \mathrm{U}$ & & 47 & \\
\hline Beryllium & $\mathrm{ppb}$ & $3 \mathrm{U}$ & & & \\
\hline Beryllium, filtered & $\mathrm{ppb}$ & $3 \mathrm{U}$ & & $3 \mathrm{U}$ & \\
\hline Bromide & $\mathrm{ppb}$ & $500 \mathrm{U}$ & & $500 \mathrm{U}$ & \\
\hline Cadmium & $\mathrm{ppb}$ & $10 \mathrm{U}$ & & & \\
\hline Cadmium, filtered & $\mathrm{ppb}$ & $10 \mathrm{U}$ & & $10 \mathrm{U}$ & \\
\hline Calcium & $\mathrm{ppb}$ & 27000 & & & \\
\hline Calcium, filtered & $\mathrm{ppb}$ & 24000 & & 53000 & \\
\hline Chloride & $\mathrm{ppb}$ & 1500 & & 5500 & \\
\hline Chromium & $\mathrm{ppb}$ & $20 \mathrm{U}$ & & & \\
\hline Chromium, filtered & $\mathrm{ppb}$ & $20 \mathrm{U}$ & & $20 \mathrm{U}$ & \\
\hline Cobalt & $\mathrm{ppb}$ & $20 \mathrm{U}$ & & & \\
\hline Cobalt, filtered & $\mathrm{ppb}$ & $20 \mathrm{U}$ & & $20 \mathrm{U}$ & \\
\hline Coliform bacteria & MPN & $1 \mathrm{U}$ & & $1 \mathrm{U}$ & \\
\hline Copper & $\mathrm{ppb}$ & $20 U$ & & & \\
\hline Copper, filtered & $\mathrm{ppb}$ & $20 \mathrm{U}$ & & $20 \mathrm{U}$ & \\
\hline Fluoride & $\mathrm{ppb}$ & 100 & & 600 & \\
\hline Iron & $\mathrm{ppb}$ & 1400 & & & \\
\hline Iron, filtered & $\mathrm{ppb}$ & $20 \mathrm{U}$ & & 24 & \\
\hline Lead (graphite furnace) & $\mathrm{ppb}$ & $5 \mathrm{U}, \mathrm{H}$ & & $5.7 \mathrm{H}$ & \\
\hline
\end{tabular}


DOE\RL-93-23, Rev. 0

Table 2-4 Groundwater Quality in the Vicinity of the N Springs ERA Site (Page 2 of 3)

\begin{tabular}{|c|c|c|c|c|c|}
\hline \multirow{2}{*}{ Constituent } & \multirow{2}{*}{ Units } & \multicolumn{2}{|c|}{ Well 199-N-2 } & \multicolumn{2}{|c|}{ Well 199-N-3 } \\
\hline & & Result & Error ${ }^{1}$ & Result & Error $^{1}$ \\
\hline Lead, filtered & $\mathrm{ppb}$ & $5 \mathrm{U}, \mathrm{H}$ & & $5 \mathrm{U}, \mathrm{H}$ & \\
\hline Magnesium & $\mathrm{ppb}$ & 5100 & & & \\
\hline Magnesium, filtered & $\mathrm{ppb}$ & 4400 & & 8900 & \\
\hline Manganese & $\mathrm{ppb}$ & 43 & & & \\
\hline Manganese, filtered & $\mathrm{ppb}$ & $10 \mathrm{U}$ & & $10 \mathrm{U}$ & \\
\hline Mercury & $\mathrm{ppb}$ & $0.2 \mathrm{U}$ & & $0.2 \mathrm{U}$ & \\
\hline Mercury, filtered & $\mathrm{ppb}$ & $0.2 \mathrm{U}$ & & $0.2 \mathrm{U}$ & \\
\hline Nickel & $\mathrm{ppb}$ & $30 \mathrm{U}$ & & & \\
\hline Nickel, filtered & $\mathrm{ppb}$ & $30 \mathrm{U}$ & & $30 \mathrm{U}$ & \\
\hline Nitrate & $\mathrm{ppb}$ & 3400 & & 15500 & \\
\hline Nitrite & $\mathrm{ppb}$ & $200 \mathrm{U}$ & & $200 \mathrm{U}$ & \\
\hline $\mathrm{pH}$, Field Measurement & & 7.92 & & 7.54 & \\
\hline Phosphate & $\mathrm{ppb}$ & $400 \mathrm{U}$ & & $400 \mathrm{U}$ & \\
\hline Potassium & ppb & 2200 & & & \\
\hline Potassium, filtered & $\mathrm{ppb}$ & 1300 & & 2700 & \\
\hline Selenium & ppb & $10 \mathrm{U}$ & & $10 \mathrm{U}$ & \\
\hline Selenium, filtered & $\mathrm{ppb}$ & $10 \mathrm{U}$ & & $10 \mathrm{U}$ & \\
\hline Silver & $\mathrm{ppb}$ & $20 \mathrm{U}$ & & & \\
\hline Silver, filtered & $\mathrm{ppb}$ & $20 \mathrm{U}$ & & $20 \mathrm{U}$ & \\
\hline Sodium & $\mathrm{ppb}$ & 2700 & & & \\
\hline Sodium, filtered & $\mathrm{ppb}$ & 2500 & & 9600 & \\
\hline Specific conductance & $\mu \mathrm{mho} / \mathrm{cm}$ & 167 & & 365 & \\
\hline Sulfate & $\mathrm{ppb}$ & 14000 & & 35000 & \\
\hline Temperature, field & DEG-C & 21.8 & & 20.9 & \\
\hline Tin & $\mathrm{ppb}$ & $100 \mathrm{U}$ & & & \\
\hline Tin, filtered & $\mathrm{ppb}$ & $100 \mathrm{U}$ & & $100 \mathrm{U}$ & \\
\hline
\end{tabular}


DOE \RL-93-23, Rev. 0

Table 2-4 Groundwater Quality in the Vicinity of the N Springs ERA Site

(Page 3 of 3)

\begin{tabular}{|c|c|c|c|c|c|}
\hline \multirow{2}{*}{ Constituent } & \multirow{2}{*}{ Units } & \multicolumn{2}{|c|}{ Well 199-N-2 } & \multicolumn{2}{|c|}{ Well 199-N-3 } \\
\hline & & Result & Error & Result & Error ${ }^{1}$ \\
\hline Total organic carbon & $\mathrm{ppb}$ & $1000 \mathrm{U}$ & & 2000 & \\
\hline $\begin{array}{l}\text { Total Organic Halogen, } \\
\text { Low Detection Level }\end{array}$ & ppb & $10 \mathrm{U}$ & & $10 \mathrm{U}$ & \\
\hline Turbidity & NTU & 2.1 & & 0.6 & \\
\hline Uranium, chemical & $\mu \mathrm{g} / \mathrm{L}$ & & & 1.66 & 0.5692 \\
\hline Vanadium & $\mathrm{ppb}$ & $30 \mathrm{U}$ & & & \\
\hline Vanadium, filtered & $\mathrm{ppb}$ & $30 \mathrm{U}$ & & $30 \mathrm{U}$ & \\
\hline Zinc & $\mathrm{ppb}$ & $10 \mathrm{U}$ & & & \\
\hline Zinc, filtered & $\mathrm{ppb}$ & $10 \mathrm{U}$ & & $10 \mathrm{U}$ & \\
\hline Cobalt -60 & $\mathrm{pCi} / \mathrm{L}$ & 12.4 & 6.304 & $4.8 \mathrm{U}$ & 9.644 \\
\hline Cesium-137 & $\mathrm{pCi} / \mathrm{L}$ & $0 \mathrm{U}$ & 0.000001 & $-7.34 \mathrm{U}$ & 8.58 \\
\hline Ruthenium-106 & $\mathrm{pCi} / \mathrm{L}$ & $-40.7 \mathrm{U}$ & 53.06 & $-22.3 \mathrm{U}$ & 61.66 \\
\hline Antimony- 125 & $\mathrm{pCi} / \mathrm{L}$ & $13.8 \mathrm{U}$ & 15.95 & $4.12 \mathrm{U}$ & 17.23 \\
\hline Tritium & $\mathrm{pCi} / \mathrm{L}$ & 30100 & 2362 & 21300 & 1760 \\
\hline Gross beta & $\mathrm{pCi} / \mathrm{L}$ & 637 & 50.04 & 1170 & 97.4 \\
\hline Strontium-90 & $\mathrm{pCi} / \mathrm{L}$ & 336 & 64.42 & 557 & 98.07 \\
\hline Radium & $\mathrm{pCi} / \mathrm{L}$ & $0.00867 \mathrm{U}$ & 0.08794 & $0.0131 \mathrm{U}$ & 0.1716 \\
\hline Gross alpha & $\mathrm{pCi} / \mathrm{L}$ & $0.202 \mathrm{U}$ & 0.5426 & $0.622 \mathrm{U}$ & 0.7956 \\
\hline \multicolumn{6}{|c|}{$\begin{array}{l}\text { U Result is less than the contract required quantitation limit (CRQL); reported value } \\
\text { is the CRQL. For radionuclides the value is less than the error. } \\
\mathrm{H} \text { Recommended holding time was exceeded. } \\
1\end{array}$} \\
\hline
\end{tabular}




\subsection{REMOVAL ACTION OBJECTIVES DEVELOPMENT}

Removal action objectives (RAO) define the "why," "what," and "when" of a removal action. Within the scope of an EE/CA study, the RAO delineate the limits of acceptable technical performance and institutional factors. The RAO are developed by first identifying the chemicals of potential concern (COPC) and ARAR.

\subsection{CHEMICALS OF POTENTIAL CONCERN}

Strontium-90 is the principal COPC at N Springs. While strontium-90 is the COPC driving this removal action, other constituents in the groundwater must be considered in the evaluation of alternatives. Tritium, for example, is elevated above Safe Drinking Water Act of 1974 maximum contaminant levels (MCL) in the $100 \mathrm{~N}$ Area and will be a significant consideration for disposal of treated groundwater. A sulfate plume is located near the strontium-90 plume; any alternative that results in changes to the groundwater flow may cause movement of the sulfate plume. Should the plumes intersect, sulfate must be addressed in the alternative evaluation and design. A similar situation exists with a hydrocarbon plume; alternatives which affect groundwater movement must consider the potential effect of the hydrocarbon on the treatment system. While these additional contaminants may effect design of the alternatives, no contaminants are present which preclude the identified alternatives. Table $2-4$ presents recent analysis of the groundwater as sampled from wells $199-\mathrm{N}-2$ and $199-\mathrm{N}-3$.

\subsection{POTENTIAL APPLICABLE OR RELEVANT AND APPROPRIATE REQUIREMENTS}

Section 121(d) of CERCLA, as amended by the Superfund Amendments and Reauthorization Act of 1986 (SARA), requires that fund-financed, enforcement, and federal facility remedial actions comply with ARAR of federal environmental laws and more stringent, promulgated state environmental or facility siting laws. While these requirements generally apply as a matter of law to remedial actions, ARAR for removal actions should be identified and complied with to the extent practicable.

The CERCLA defines applicable requirements as those cleanup standards, standards of control, and other substantive environmental protection requirements, criteria, or limitations promulgated under federal or state law that specifically address a hazardous substance, pollutant, contaminant, remedial action, location, or other circumstance at a CERCLA site.

Relevant and appropriate requirements are those cleanup standards, standards of control, and other substantive environmental protection requirements, criteria, or limitations promulgated under federal or state law that, while not "applicable" to a hazardous substance, pollutant, contaminant, remedial action, location, or other circumstance at a CERCLA site, 
address problems or situations sufficiently similar to those encountered at the CERCLA site that their use is well suited to the particular site.

In addition to ARAR, CERCLA also provides for the consideration of to-be-considered (TBC) guidance, nonpromulgated advisories or guidance documents issued by federal or state governments that do not have the status of potential ARAR but which may be considered in determining necessary levels of protection of health or the environment.

Appiicable or relevant and appropriate requirements may be further subdivided into the following categories:

- Chemical-specific requirements - health-or risk-based numerical values or methodologies that, when applied to site-specific conditions, result in the establishment of numerical values. If a chemical has more than one such requirement that is $A R A R$, compliance should generally be with the most stringent requirement.

- Location-specific requirements - restrictions placed on the concentration of hazardous substances or the conduct of activities solely because they are in specific locations, such as wetlands or historic places.

- Action-specific requirements - technology- or activity-based requirements or limitations on actions taken with respect to hazardous wastes. These requirements are triggered by the particular remedial activities that are selected to accomplish a remedy.

Potential ARAR identified in the 100 Area Feasibility Study, Phases 1 and 2 (DOE-RL 1993) were reviewed and refined for appropriateness to the N Springs ERA. Potential chemical-specific ARAR and TBC identified for the N Springs ERA are listed in Tables 3-1 through 3-3. Potential action- and location-specific ARAR and TBC are presented in Tables 3-4 through 3-9.

\subsection{REMOVAL ACTION OBJECTIVES}

The primary objective of the N Springs ERA is to eliminate or significantly reduce the flux of strontium-90 to the Columbia River through the N Springs. For purposes of this evaluation, significant reduction was considered to be at least $50 \%$ of the strontium-90 concentrations greater than $1,000 \mathrm{pCi} / \mathrm{L}$. Currently, strontium-90 is being discharged to the river via the $N$ Springs at concentrations that exceed the drinking water $\mathrm{MCL}$ of $8 \mathrm{pCi} / \mathrm{L}$ for strontium-90. A secondary objective of the ERA is to implement a removal action that will be compatible with future remedial actions planned for the operable unit and will contribute to the efficient performance of the final remedial action to be taken. 
DOE\RL-93-23, Rev. 0

For those alternatives that include extraction of contaminated groundwater, the objective is to treat the water to MCL prior to disposal. Tritium is the exception because treatment for tritium removal is currently unavailable. Disposal of tritiated water will require waivers of applicable ARAR. 


\begin{tabular}{|c|c|c|c|}
\hline Description & Citation & Requirements & Remarks \\
\hline Clean Air Act, as amended & $\begin{array}{l}42 \text { U.S.C. } 7401 \text { et } \\
\text { seq. }\end{array}$ & $\begin{array}{l}\text { A comprehensive environmental law designed to regulate any } \\
\text { activities that affect air quality, providing the national } \\
\text { framework for controlling air pollution. }\end{array}$ & \\
\hline $\begin{array}{l}\text { National Primary and Secundary } \\
\text { Ambient Air Quality Standards }\end{array}$ & 40 CFR Part 50 & $\begin{array}{l}\text { Sets National Ambient Air Quality Standards for ambient } \\
\text { pollutants which are regulated within a region. }\end{array}$ & \\
\hline $\begin{array}{l}\text { Air Standards for } \\
\text { Paniculates }\end{array}$ & 40 CFR 850.6 & $\begin{array}{l}\text { Prohibits average concentrations of particulate emissions in } \\
\text { excess of } 50 \mathrm{micrograms} / \mathrm{m}^{\prime} \text { annually or } 150 \mathrm{micrograms} / \mathrm{m}^{3} \text { per } \\
\text { 24-ho'sr period. }\end{array}$ & $\begin{array}{l}\text { A potential for particulate emissions exists } \\
\text { during excavation for vertical barrier } \\
\text { installation. }\end{array}$ \\
\hline $\begin{array}{l}\text { National Emissions Standards for } \\
\text { Hazardous Air Pollutants } \\
\text { (NESHAP) }\end{array}$ & 40 CFR Pan 61 & Estaviishes numerical standards for hazardous air pollutants. & \\
\hline $\begin{array}{l}\text { Radionuclide Emissions } \\
\text { from DOE Facilities } \\
\text { (except Aitrome } \\
\text { Radon-222) }\end{array}$ & 40 CFR $\$ 61.92$ & $\begin{array}{l}\text { Prohibits emissions of radionuclides to the ambient air } \\
\text { exceeding an effective dose equivalent of } 10 \text { mrem per year. }\end{array}$ & $\begin{array}{l}\text { Applicable to removal technologies where } \\
\text { air emissions may occur. }\end{array}$ \\
\hline $\begin{array}{l}\text { Federal Water Pollution Control Act. } \\
\text { as amended by the Clean Water Act } \\
\text { of } 1977\end{array}$ & $\begin{array}{l}33 \text { U.S.C. } 1251 \text { et } \\
\text { sey. }\end{array}$ & $\begin{array}{l}\text { Creates the basic national framework for water pollution control } \\
\text { and water quality management. }\end{array}$ & \\
\hline $\begin{array}{l}\text { National Pollutant Discharge } \\
\text { Elimination System (NPDES) }\end{array}$ & 40 CFR Pan 122 & $\begin{array}{l}\text { Establishes permitting requirements, lechnology-based } \\
\text { limitations and standards, control of toxic pollutants, and } \\
\text { monitoring of efmuents to assure permit conditions and limits } \\
\text { are not exceeded. }\end{array}$ & $\begin{array}{l}\text { Permit may not be required for CERCLA } \\
\text { actions; however, substantive requirements } \\
\text { must be met. }\end{array}$ \\
\hline Permit Conditions & $\begin{array}{l}40 \text { CFR } \$ 122.41- \\
122.50\end{array}$ & $\begin{array}{l}\text { Establishes conditions that apply to NPDES permits including } \\
\text { efluent limitations and monitoring requirements. }\end{array}$ & $\begin{array}{l}\text { Applicable to direct discharges of } \\
\text { wastewaters to waters of the U.S. } \\
\text { Treantment of process waters that will be } \\
\text { discharged to waters of the U.S. will be } \\
\text { required to meet all applicable effuent } \\
\text { limilations, quality standards, and toxic } \\
\text { pollutant discharge standards as determined } \\
\text { by the state, and/or federal diacharge } \\
\text { permitting authority. }\end{array}$ \\
\hline
\end{tabular}




\begin{tabular}{|c|c|c|c|}
\hline Description & Citation & Requirements & Remarks \\
\hline Safe Drinking Water Act & $\begin{array}{l}42 \text { U.S.C. } 300 f \text { et } \\
\text { seq. }\end{array}$ & $\begin{array}{l}\text { Creates a comprehensive national framework to ensure the } \\
\text { quality and eafety of drinking water. }\end{array}$ & \\
\hline $\begin{array}{l}\text { National Primary Drinking Water } \\
\text { Regulations }\end{array}$ & 40 CFR Pan 141 & $\begin{array}{l}\text { Establishes maximum contaminant levels (MCL) and maximum } \\
\text { contaminant level goals (MCLG) for organic, inorganic, and } \\
\text { radioactive constituents. The MCL for } \mathrm{Sr}-90 \text { is } 8 \mathrm{pCi} / \mathrm{L} \text {. The } \\
\text { average annual concentration of bela particle and photon } \\
\text { radicastivity from manmade radionuclides in drinking water } \\
\text { shall not produce an annual dose equivalent to tolal body or any } \\
\text { internal organ in excess of } 4 \text { mrem/year. }\end{array}$ & $\begin{array}{l}\text { Pernains to public drinking water supplies. } \\
\text { Chemicals of polential concern are being } \\
\text { discharged to the river which serves as a } \\
\text { drinking water supply downeream. }\end{array}$ \\
\hline $\begin{array}{l}\text { National Secondary Drinking } \\
\text { Water Regulations }\end{array}$ & 40 CFR Pan 143 & $\begin{array}{l}\text { Controls conteminants in drinking water that primarily affect the } \\
\text { aesthetic qualities relating to the public acceptance of drinking } \\
\text { water. }\end{array}$ & 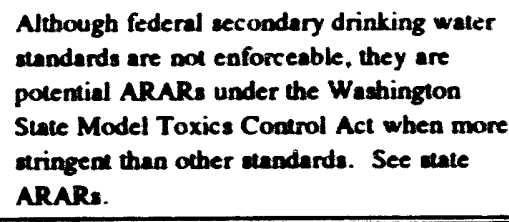 \\
\hline
\end{tabular}




\begin{tabular}{|c|c|c|c|}
\hline Description & Citation & Requirements & Remarts \\
\hline \multirow{2}{*}{$\begin{array}{l}\text { Nuclear Energy and Radiation } \\
\text { Radiation Protection - Air } \\
\text { Emissions }\end{array}$} & \multicolumn{3}{|l|}{ RCW 70.98} \\
\hline & WAC 246-247 & $\begin{array}{l}\text { Requires that emiasions of ndionuclides to the air thall nol cause a } \\
\text { coue equivalent of more than } 25 \text { mrem/year to the whole body or } \\
75 \text { mrem/year to a critical organ of any member of the public. }\end{array}$ & \\
\hline Model Toxics Control Act (MTCA) & 70.105D RCW & $\begin{array}{l}\text { Requires remedial actions to atsin a degree of cleanup protective of } \\
\text { human health and the environment. }\end{array}$ & \multirow{6}{*}{ 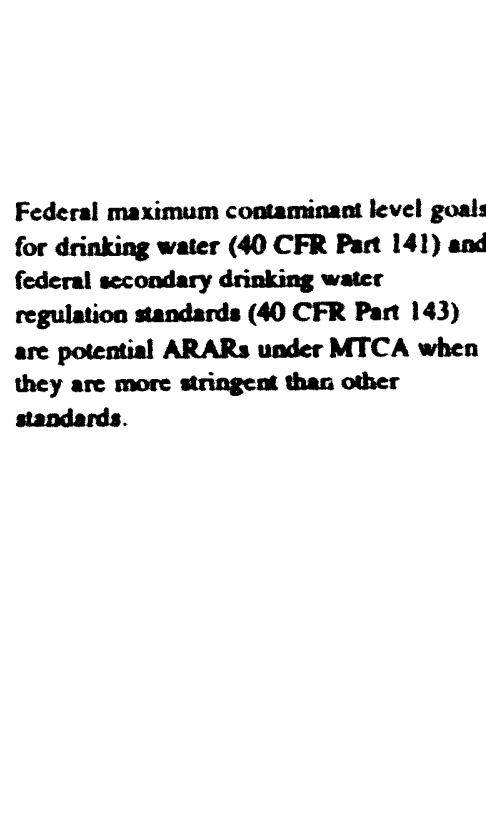 } \\
\hline Cleanup Regulations & WAC $173-340$ & $\begin{array}{l}\text { Establishes cleanup levels and prescribes methods to calculate } \\
\text { cleanup levels for groundwater. }\end{array}$ & \\
\hline \multirow[t]{4}{*}{$\begin{array}{l}\text { Groundwater Cleanup } \\
\text { Sundards }\end{array}$} & WAC $173 \cdot 340-720$ & $\begin{array}{l}\text { Requires that where the groundwater is a potential source of } \\
\text { drinking water, cleanup levels under Method B must be at least as } \\
\text { stringent as concentrations esablished under applicable state and } \\
\text { federal laws, including the following: } \\
\text { (A) Maximum contaminsat levels established under the Safe } \\
\text { Drinking Water Act and published in } 40 \text { CFR } 141 \text {, as amended; }\end{array}$ & \\
\hline & & $\begin{array}{l}\text { (B) Maximum contaminant level goals for noncarcinogens } \\
\text { established under the Safe Drinking Water Act and published in } 40 \\
\text { CFR 141, as amended; }\end{array}$ & \\
\hline & & $\begin{array}{l}\text { (C) Secondary maximum contaminant levels established under the } \\
\text { Safe Drinking Water Act and published in } 40 \text { CFR 143, as } \\
\text { amended: and }\end{array}$ & \\
\hline & & $\begin{array}{l}\text { (D) Maximum contaminant levels established by the state board of } \\
\text { health and published in Chapter } 248-54 \text { WAC. as amended. }\end{array}$ & \\
\hline
\end{tabular}




\begin{tabular}{|c|c|c|c|}
\hline Description & Citation & Requirements & Remarks \\
\hline Safe Drinking Water Act & 42 U.S.C. 300 f et seq. & & \multirow{3}{*}{$\begin{array}{l}\text { When promulgated, there proposed rules will } \\
\text { replace sections in } 40 \text { CFR } 141 \text { and } 142\end{array}$} \\
\hline \multirow[t]{2}{*}{$\begin{array}{l}\text { National Primary Drinking } \\
\text { Water Regulations; } \\
\text { Radionuclides - Proposed Rules }\end{array}$} & \multirow[t]{2}{*}{$\begin{array}{l}\text { FR Vol. } 56, \text { No. } 138 . \\
\text { July 18, } 1991\end{array}$} & $\begin{array}{l}\text { Provides numerical sandards for radionuclides } \\
\text { corresponding to } 4 \mathrm{mrem} / \mathrm{yr} \text { dose through drinking water } \\
\text { as follows ( } \mathrm{pCi} / \mathrm{L} \text { ): }\end{array}$ & \\
\hline & & $\begin{array}{lr}\text { Tritium } & 69.040 \\
\text { Strontium-90 } & 42\end{array}$ & \\
\hline \multicolumn{4}{|l|}{ U.S. Department of Fnergy Onders } \\
\hline $\begin{array}{l}\text { Radiation Protection of the } \\
\text { Public and the Envirunment }\end{array}$ & DOE 5400.5 & $\begin{array}{l}\text { Establishes radiation protection standards for the public } \\
\text { and environment. }\end{array}$ & \\
\hline $\begin{array}{l}\text { Radiation Dose Limit (All } \\
\text { Pathways) }\end{array}$ & $\begin{array}{l}\text { DOE } 5400.5 \text {, } \\
\text { Chapter II, Section 1a }\end{array}$ & $\begin{array}{l}\text { The exposure of the public to radiation wurces as a } \\
\text { consequence of all routine DOE activities ahall not cause, } \\
\text { in a year, an effective dose equivalent greater than } 100 \\
\text { mrem from all exposure pathways, except under specified } \\
\text { circumstances. }\end{array}$ & $\begin{array}{l}\text { Pertinent if remedial activitiea are "routine DOE } \\
\text { aetivities:" }\end{array}$ \\
\hline $\begin{array}{l}\text { Radiation Duse Limit (Drinking } \\
\text { Water Pathway) }\end{array}$ & $\begin{array}{l}\text { DOE } 5400.5 \text {. } \\
\text { Chapter II. Section Id }\end{array}$ & $\begin{array}{l}\text { Provides a level of protection for persons consuming } \\
\text { water from a public drinking water supply operated by } \\
\text { DOE so that persons consuming water from the supply } \\
\text { shall not receive an effective dose equivalent greater than } \\
4 \text { mrem per year. Combined radium-226 and radium- } \\
228 \text { shall not exceed } 5 \times 10^{\circ} \mu \mathrm{C} / / \mathrm{mL}^{\circ} \text { and gross alpha } \\
\text { activity (including radium- } 226 \text { but excluding radon and } \\
\text { uraniuni) hall not exceed } 1.5 \times 10^{-4} \mu \mathrm{Ci} / \mathrm{mL} \text {. }\end{array}$ & $\begin{array}{l}\text { Pertinent if radionuclides may be released during } \\
\text { remediation. }\end{array}$ \\
\hline
\end{tabular}




\begin{tabular}{|c|c|c|c|}
\hline Description & Citation & Requirements & Remarks \\
\hline $\begin{array}{l}\text { Federal Water Pollution Control Act } \\
\text { (FWPCA), as amended by the Clean } \\
\text { Water Act of } 1977 \text { (CWA) }\end{array}$ & 33 U.S.C. 1251 et seq. & $\begin{array}{l}\text { Creates the basic national framework for water pollution control and } \\
\text { water quality management in the United States. }\end{array}$ & \\
\hline $\begin{array}{l}\text { The National Pollutant } \\
\text { Discharge Elimination System } \\
\text { (NPDES) }\end{array}$ & 40 CFR Pan 122 & $\begin{array}{l}\text { Part } 122 \text { covers establishing technology-based limitations and } \\
\text { standards, control of toxic pollutants, and monitoring of effluent to } \\
\text { assure limits are not exceeded. }\end{array}$ & $\begin{array}{l}\text { Applicable to river discharge } \\
\text { option for treated groundwater } \\
\text { disposal; also applies to storm } \\
\text { water runoff associaled with } \\
\text { industrial activities. }\end{array}$ \\
\hline NPDES Criteria and Standards & 40 CFR $\$ 125.104$ & $\begin{array}{l}\text { Best management practices program sha!l be developed in accordance } \\
\text { with good engineering practice. }\end{array}$ & \\
\hline \multicolumn{4}{|l|}{$\begin{array}{l}\text { Safe Drinking Water Act (SDWA), as } \\
\text { amended }\end{array}$} \\
\hline $\begin{array}{l}\text { Underground Injection Control (UIC) } \\
\text { Program }\end{array}$ & 40 CFR Pan 144 & Identifies the minimum requirements for UIC programs. & $\begin{array}{l}\text { Applicable for the reinjection } \\
\text { option of treated groundwater } \\
\text { disposal. }\end{array}$ \\
\hline $\begin{array}{l}\text { Criteria and Standards for the } \\
\text { Underground Injection Control } \\
\text { Program }\end{array}$ & 40 CFR Pan 146 & $\begin{array}{l}\text { Establishes siting, construction, operating, monitoring, and closure } \\
\text { requirements for all classes of injection wells. }\end{array}$ & $\begin{array}{l}\text { Applicable for the reinjection } \\
\text { option of treated groundwater } \\
\text { disposal. }\end{array}$ \\
\hline \multicolumn{4}{|l|}{$\begin{array}{l}\text { Resource Conservation and Recovery Act } \\
\text { (RCRA) }\end{array}$} \\
\hline $\begin{array}{l}\text { Identification and Listing of } \\
\text { Hazardous Waste }\end{array}$ & 40 CFR Pan 261 & $\begin{array}{l}\text { Identifies by both listing and characterization, those solid wastes } \\
\text { subject to regulation as hazardous wastes under Parns } 261-265,268 \\
\text { and } 270 \text {. }\end{array}$ & $\begin{array}{l}\text { Applicable if remediation } \\
\text { techniques result in generation of } \\
\text { hazardous wastes. }\end{array}$ \\
\hline $\begin{array}{l}\text { Standards Applicable to Generators of } \\
\text { Hazardous Waste }\end{array}$ & 40 CFR Part 262 & $\begin{array}{l}\text { Describes regulatory requirements imposed on generator of } \\
\text { hazardous wastes who treat, store, or dispose of the waste on-site. }\end{array}$ & $\begin{array}{l}\text { Applicable if remediation } \\
\text { techniques results in generations } \\
\text { of hazardous wastes. }\end{array}$ \\
\hline
\end{tabular}




\begin{tabular}{|c|c|c|c|}
\hline Description & Citation & Requirements & Remarks \\
\hline Department of Ecology & 43.21A RCW & $\begin{array}{l}\text { Vests the Washington Deparment of Ecology with the } \\
\text { authority to underake the state air regulation and management } \\
\text { program. }\end{array}$ & \\
\hline Air Pollution Regulations & WAC $173-400$ & $\begin{array}{l}\text { Establishes requirements for the control and/or prevention of } \\
\text { the emission of air contaminants. }\end{array}$ & $\begin{array}{l}\text { Applicable if emission sources are created } \\
\text { during remedial action. }\end{array}$ \\
\hline $\begin{array}{l}\text { Stundards for ':laximum } \\
\text { Emissions }\end{array}$ & WAC $173-400-040$ & $\begin{array}{l}\text { Requires best available control technology be used to control } \\
\text { fugitive emissions of dust from materials handling, } \\
\text { construction, demolition. or any other activities that are sources } \\
\text { of fugitive emissions. Restricts emitted particulates from being } \\
\text { deposited beyond Hanford. Requires control of odors emitted } \\
\text { from the source. Prohibits masking or concealing prohibited } \\
\text { emissions. Requires measures to prevent fugitive dust from } \\
\text { becoming airborne. }\end{array}$ & $\begin{array}{l}\text { Applicable to dust emissions from cuting } \\
\text { of concrete and metal and vehicular traffic } \\
\text { during remediation. }\end{array}$ \\
\hline Emission Limits for Radionuclides & WAC 173.480 & Controls air emissions of radionuclides from specific sources. & $\begin{array}{l}\text { Applicable to remedial activities that result } \\
\text { in air emissions. }\end{array}$ \\
\hline $\begin{array}{l}\text { New and Mixdified Emission } \\
\text { Units }\end{array}$ & WAC $173-480-060$ & $\begin{array}{l}\text { Requires the best available radionuclide control technol:ggy be } \\
\text { utilized in planning construction, instailation, or establishing a } \\
\text { new enission unit. }\end{array}$ & $\begin{array}{l}\text { Applicable to remedial actions that result in } \\
\text { air emissions. }\end{array}$ \\
\hline Dangerous Wasti Regulations & WAC $173-303$ & $\begin{array}{l}\text { Establishes the design, operation and montitoring requirements } \\
\text { for management of hazardous wastes. }\end{array}$ & $\begin{array}{l}\text { Includes requirements for generators of } \\
\text { dangerous waste. Dangerous wastic } \\
\text { includes the full universe of wastes } \\
\text { regulated by WAC } 173-303 \text { including } \\
\text { extremely hazardous waste. }\end{array}$ \\
\hline
\end{tabular}




\begin{tabular}{|c|c|c|c|}
\hline Description & Citation & Requirements & Remarks \\
\hline \multirow[t]{2}{*}{ Model Toxics Control Act } & $70.105 \mathrm{D} \mathrm{RCW}$ & $\begin{array}{l}\text { Authorizes the state to investigate releases of hazardous } \\
\text { substances, conduct remedial actions, carry out state programs } \\
\text { authorized by federal cleanup laws, and to take other actions. }\end{array}$ & \\
\hline & WAC $173-340$ & $\begin{array}{l}\text { Addresses reieases of hazardous substances caused by past } \\
\text { activities. and potential and ongoing releases from current } \\
\text { activities. }\end{array}$ & $\begin{array}{l}\text { Applicable to facilitiea where hazardouss } \\
\text { substances have been released, or there is a } \\
\text { threatened release that may pose a threat to } \\
\text { human health or the environment. }\end{array}$ \\
\hline $\begin{array}{l}\text { Selection of Cleanup } \\
\text { Actions }\end{array}$ & WAC $173-340-360$ & $\begin{array}{l}\text { Establishes cleanup requirements to include in cleanup plans. } \\
\text { Identifies technologies to be considered for remediation of } \\
\text { hazardous substances. }\end{array}$ & \\
\hline Cleanup Actions & WAC $173 \cdot 340-400$ & $\begin{array}{l}\text { Ensures that the cleanup action is designed, constructed, and } \\
\text { operated in accordance with the cleanup plan and other } \\
\text { specified requirements. }\end{array}$ & \\
\hline Institutional Controls & WAC $173-340440$ & $\begin{array}{l}\text { Requires physical measures such as fences and signs to limit } \\
\text { interference with cleanup, and legal and admiristrative } \\
\text { mechanisms to enforce them. }\end{array}$ & \\
\hline \multirow{2}{*}{$\begin{array}{l}\text { Water Pollution Control Act } \\
\text { Underground Injection Control } \\
\text { Program }\end{array}$} & $90.48 \mathrm{RCW}$ & Prohibits discharge of polluting matter in waters. & \\
\hline & WAC 173-218 & $\begin{array}{l}\text { Establishes permitting requirements for injection of fluids } \\
\text { through wells. Prohibits injection of any dangerous or } \\
\text { radioactive waste fluids. Prohibits injection of industrial or } \\
\text { commercial waste fluids beneath the lowermost formation } \\
\text { containing. within i } / 4 \text { mile of the well. an underground source } \\
\text { of drinking water. }\end{array}$ & $\begin{array}{l}\text { Federal Criteria and Standards for the } \\
\text { Underground Injection Control Program } \\
\text { (40 CFR 146) are reserved at this time. }\end{array}$ \\
\hline $\begin{array}{l}\text { State Waste Discharge Permit } \\
\text { Program }\end{array}$ & WAC $173-216$ & & \\
\hline Permit terms and conditions & WAC $173 \cdot 216-130$ & $\begin{array}{l}\text { Requires all known. available, and reasonable methods of } \\
\text { prevention. control, and treatment be used as a condition of the } \\
\text { permit to discharge to the waters of the state. }\end{array}$ & $\begin{array}{l}\text { While a permit is not required under } \\
\text { CERCLA actions, the substantive } \\
\text { requirements of that permit must be met. }\end{array}$ \\
\hline Water Well Construction Act & i8.104 RCW & & \\
\hline $\begin{array}{l}\text { Standards fir Construction } \\
\text { and Maintenance of Wells }\end{array}$ & WAC 173.160 & $\begin{array}{l}\text { Establishes minimum standards for design. construction. } \\
\text { capping. and sealing of all wells. Sets additional requirements } \\
\text { including disinfection of equipment. abandonment of wells. and } \\
\text { quality of drilling water. }\end{array}$ & $\begin{array}{l}\text { Applicable if water supply wells. } \\
\text { monitoring wells. or other wells are utilized } \\
\text { during remediation. }\end{array}$ \\
\hline
\end{tabular}




\begin{tabular}{|c|c|c|c|}
\hline Description & Citation & Requirements & Remarks \\
\hline $\begin{array}{l}\text { Residual Radioactive Material as } \\
\text { Surface Contamination }\end{array}$ & $\begin{array}{l}\text { U.S. NRC Regulatory } \\
\text { Guide } 1.86\end{array}$ & $\begin{array}{l}\text { Sets contamination guidelines for release of equipment and building } \\
\text { components for unnestricted use, and if buildings are demolished, ahall } \\
\text { not be exceeded for contamination in the ground. }\end{array}$ & \\
\hline \multicolumn{4}{|l|}{$\begin{array}{l}\text { U.S. Department of Energy } \\
\text { Orders }\end{array}$} \\
\hline $\begin{array}{l}\text { Radiation Protection of the } \\
\text { Public and the Environment }\end{array}$ & DOE 5400.5 & $\begin{array}{l}\text { Establishes standards and requirements for operations of DOE and } \\
\text { DOE contractors respecting protection of the public and the } \\
\text { environment against undue risk of radiation. }\end{array}$ & \\
\hline $\begin{array}{l}\text { Discharge of Treatment } \\
\text { System Emuent }\end{array}$ & DOE $5400 . x y$ & $\begin{array}{l}\text { Treatment systems shall be designed to allow operators to detect and } \\
\text { quantify unplanned releases of radionuclides, consistent with the } \\
\text { potential for off-propery impact. }\end{array}$ & $\begin{array}{l}\text { Required of all DOE-controlled } \\
\text { facilities where radionuclides might be } \\
\text { released as a consequence of an } \\
\text { unplanned event. }\end{array}$ \\
\hline $\begin{array}{l}\text { Radiation Protection for } \\
\text { Occupational Workers }\end{array}$ & $\begin{array}{l}\text { DOE } 5480.11 \\
\text { Section } 9 \mathrm{a}\end{array}$ & $\begin{array}{l}\text { Establishes radiation protection standards and program requirements to } \\
\text { protect workers from ionizing radiation. }\end{array}$ & \\
\hline $\begin{array}{l}\text { Radioactive Waste } \\
\text { Management }\end{array}$ & $\begin{array}{l}\text { DOE } 5820.2 \mathrm{~A} \\
\text { Chapters III and IV }\end{array}$ & $\begin{array}{l}\text { Establishes policies and guidelines by which DOE manages radioactive } \\
\text { waste, waste by-products, and radioactive contaminated surplus } \\
\text { facilities. Disposal shall be on the site at which it was generated, if } \\
\text { practical, or at another DOE facility. DOE waste containing byproduct } \\
\text { material shall be stored, stabilized in place, and/or disposed of } \\
\text { consistent with the requirements of the residual radioactive material } \\
\text { guidelines contained in } 40 \text { CFR } 192 \text {. }\end{array}$ & \\
\hline
\end{tabular}




\begin{tabular}{|c|c|c|c|}
\hline Description & Citation & Requirements & Remarks \\
\hline $\begin{array}{l}\text { Archaeological and Historical } \\
\text { Preservation Act of } 1974\end{array}$ & 16 U.S.C. 469 & $\begin{array}{l}\text { Requires action to recover and preserve artifacts in areas where } \\
\text { activity may cause irreparable harm, loss, or destruction of } \\
\text { significant artifacts. }\end{array}$ & $\begin{array}{l}\text { Applicable because of the presence of } \\
\text { significant scientific, prehistorical, } \\
\text { historical, or archeological dala in the } N \\
\text { Area. }\end{array}$ \\
\hline Endangered Species Act of 1973 & 16 U.S.C. 1531 et seq. & $\begin{array}{l}\text { Prohibits federal agencies from jeopardizing threatened or } \\
\text { endangered species or adversely modifying habitats essential to } \\
\text { their survival. }\end{array}$ & \\
\hline $\begin{array}{l}\text { Fish and Wildlife } \\
\text { Services List of } \\
\text { Endangered and } \\
\text { Threatened Wildlife and } \\
\text { Plants }\end{array}$ & $\begin{array}{l}50 \text { CFR Parts 17. } 222 . \\
225,226,227,402 \\
424\end{array}$ & $\begin{array}{l}\text { Requires identification of activities that may affect listed } \\
\text { species. Actions must not threaten the continued existence of a } \\
\text { listed species or destroy critical habitat. }\end{array}$ & $\begin{array}{l}\text { Requires consultation with the Fish and } \\
\text { Wildlife Service to determine if threatened } \\
\text { or endangered species could be impacted } \\
\text { by activity. }\end{array}$ \\
\hline $\begin{array}{l}\text { Historic Sites, Buildings, and } \\
\text { Antiquities Act }\end{array}$ & 16 U.S.C. 461 & $\begin{array}{l}\text { Establishes requirements for preservation of historic sites, } \\
\text { buildings, or objects of national significance. Undesirable } \\
\text { impacts to such resources must be mitigated. }\end{array}$ & Applicable because of the presence of \\
\hline $\begin{array}{l}\text { National Historic Preservation } \\
\text { Act of } 1966 \text {, as amended. }\end{array}$ & 16 U.S.C. 470 et seq. & $\begin{array}{l}\text { Prohibits impacts on cultural resources. Where impacts are } \\
\text { unavoidable, requires impact mitigation through design and data } \\
\text { recovery. }\end{array}$ & $\begin{array}{l}\text { Applicable to properties listed in the } \\
\text { National Register of Historic Places, or } \\
\text { eligible for such listing. }\end{array}$ \\
\hline Wild and Scenic Rivers Act & 16 U.S.C. 1271 & $\begin{array}{l}\text { Prohibits federal agencies from recommending authorization of } \\
\text { any water resource project that would have a direct and adverse } \\
\text { effect on the values for which a river was designated as a wild } \\
\text { and scenic river or included as a study area. }\end{array}$ & $\begin{array}{l}\text { The Hanford Reach of the Columbia River } \\
\text { is under study for inclusion as a wild and } \\
\text { scenic river. }\end{array}$ \\
\hline
\end{tabular}




\begin{tabular}{|c|c|c|c|}
\hline Description & Citation & Requirements & Remarks \\
\hline $\begin{array}{l}\text { Habitat Buffer Zone for Bald } \\
\text { Eagle Rules }\end{array}$ & RCW 77.12 .655 & & \\
\hline $\begin{array}{l}\text { Bald Eagle Protection } \\
\text { Rules }\end{array}$ & WAC 232-12-292 & $\begin{array}{l}\text { Prescribes sction to protect bald eagle habitat, such as nesting or } \\
\text { roost sites, through the development of a site management plan. }\end{array}$ & $\begin{array}{l}\text { Applicable if the areas of remedial } \\
\text { activities includes bald eagle habitat. }\end{array}$ \\
\hline $\begin{array}{l}\text { Regulating the Taking or } \\
\text { Possessing of Game }\end{array}$ & RCW 77.12 .040 & & \\
\hline $\begin{array}{l}\text { Endangered. Threatened, } \\
\text { or Sensitive Wildlife } \\
\text { Species Classification }\end{array}$ & WAC $232-12-297$ & $\begin{array}{l}\text { Prescribes action to protect wildlife classified as endangered, } \\
\text { threatened, or sensitive, through development of a site } \\
\text { management plan. }\end{array}$ & $\begin{array}{l}\text { Applicable if wildlife classified as } \\
\text { endangered, threatened, or sensitive are } \\
\text { present in areas impacted by remedial } \\
\text { activities. }\end{array}$ \\
\hline
\end{tabular}




\begin{tabular}{|c|c|c|c|}
\hline Description & Citation & Requirements & Remarks \\
\hline $\begin{array}{l}\text { Floodplains/Wellands } \\
\text { Environmental Review }\end{array}$ & 10 CFR Part 1022 & $\begin{array}{l}\text { Requires federal agencies to avoid, to the extent possible, adverse } \\
\text { effects associated with the development of a floodplain or the } \\
\text { destruction or loss of wellands. }\end{array}$ & $\begin{array}{l}\text { Pertinent if remedial activities take } \\
\text { place in a floodplain or wetlands. }\end{array}$ \\
\hline $\begin{array}{l}\text { Protection and } \\
\text { Enhancement of the } \\
\text { Cultural Environment }\end{array}$ & Execulive Order 11593 & $\begin{array}{l}\text { Provides direction to federal agencies to preserve, restore, and } \\
\text { maintain cultural resources. }\end{array}$ & $\begin{array}{l}\text { Persins to sites, atructures, and } \\
\text { objects of historical, archeological, } \\
\text { or architectural significance. }\end{array}$ \\
\hline Hanford Reach Study Act & PL $100-605$ & $\begin{array}{l}\text { Provides for a comprehensive river conservation study. Prohibits } \\
\text { the construction of any dam, channel, or navigation project by a } \\
\text { federal agency for } 8 \text { years after enactment. New federal and non- } \\
\text { federal projects and activities are required, to the extent practicable, } \\
\text { to minimize direct and adverse effects on the values for which the } \\
\text { river is under study and to utilize existing strectures. }\end{array}$ & $\begin{array}{l}\text { This law was enacted November } 4 \text {, } \\
1988 .\end{array}$ \\
\hline
\end{tabular}




\subsection{IDENTIFICATION OF REMOVAL ACTION TECHNOLOGIES}

The 100 Area Feasibility Study Phases 1 and 2 (DOE-RL 1993) serves as a basis for defining technologies and process options considered for this ERA. Technology types are general groups of operations with common characteristics or results, such as physical treatment. Process options are specific operations within a technology type, such as ion exchange. The process options defined in the feasibility study (FS) for vertical barriers, hydraulic control, and groundwater physical, biological, and chemical treatment technology types are screened for applicability to the circumstances at N Springs. Table 4-1 identifies those technologies and process options relevant to the proposed action at $\mathrm{N}$ Springs that were considered in the FS. Some of these technologies are eliminated from further consideration because they do not specifically address the type of contamination at N Springs; that is, they are not applicable. The rationale for the elimination of technologies and process options is indicated in the table. Descriptions of the technologies that are eliminated are given in the FS (DOE-RL 1993). Technologies that are retained for further consideration are briefly described in Section 6.9. Screening of technologies and process options against the removal action screening criteria is documented in Section 5.0. 
DOE $\backslash$ RL-93-23, Rev. 0

Table 4-1 Technology Identification (Page 1 of 2)

\begin{tabular}{|c|c|}
\hline Technology & Is technology applicable to $\mathbf{N}$ Springs? \\
\hline \multicolumn{2}{|r|}{ Vertical Barriers } \\
\hline Slurry Wall & Yes \\
\hline Grout Curtain & Yes \\
\hline Sheet Pilings & Yes \\
\hline Freeze Wall & Yes \\
\hline Biological Barriers & $\begin{array}{l}\text { No; difficult to maintain stable barrier and potential to } \\
\text { mobilize contaminants }\end{array}$ \\
\hline Permeable Treatment Beds & Yes \\
\hline \multicolumn{2}{|r|}{ Pump and Treat } \\
\hline Extraction Wells & Yes \\
\hline Ion Exchange & Yes \\
\hline Media Filtration & $\begin{array}{l}\text { Yes; consider for water pretreatment to remove suspended } \\
\text { solids }\end{array}$ \\
\hline Flocculation/Precipitation & Yes \\
\hline Carbon Adsorption & No; used for VOC \\
\hline Air Stripping & No; used for VOC \\
\hline Reverse Osmosis & Yes \\
\hline Ultrafiltration & No; used for higher molecular weight contaminants \\
\hline Electrodialysis & No; has not been proven for radionuclides \\
\hline Dissolved Air Flotation & $\begin{array}{l}\text { No; used for removing fine solids with densities close to } \\
\text { water }\end{array}$ \\
\hline Sedimentation & $\begin{array}{l}\text { Yes; consider for pretreatment to remove larger sediment } \\
\text { particles in suspension (in conjunction with media } \\
\text { filtration) }\end{array}$ \\
\hline Steam Stripping & No; used for organics \\
\hline Forced Evaporation & $\begin{array}{c}\text { Yes; as a secondary treatment for treatment of waste } \\
\text { liquids to reduce volume }\end{array}$ \\
\hline Freeze Crystallization & No; used for heavy metals and partially soluble organics \\
\hline
\end{tabular}


DOE $\backslash$ RL-93-23, Rev. 0

Table 4-1 Technology Identification (Page 2 of 2)

\begin{tabular}{|c|c|}
\hline Technology & Is technology applicable to N Springs? \\
\hline Supported Liquid Membrane & Yes \\
\hline Chemical Oxidation & No; used for organics \\
\hline Wet-Air Oxidation & No; used for organics \\
\hline Chemical Reduction & No; used for hexavalent chromium \\
\hline Solidification/Stabilization & $\begin{array}{c}\text { Yes; consider as secondary treatment for treatment } \\
\text { residues }\end{array}$ \\
\hline \multicolumn{2}{|r|}{ Hydraulic Control } \\
\hline Extraction Wells & Yes \\
\hline Extraction Trenches & Yes \\
\hline \multicolumn{2}{|r|}{ Treated Water Disposal } \\
\hline Crib Disposal & Yes \\
\hline River Discharge & Yes \\
\hline Reinjection & Yes \\
\hline Passive solar evaporation & Yes \\
\hline Double Shell Tanks & $\begin{array}{l}\text { No; capacity not available; volume increase of high level } \\
\text { waste }\end{array}$ \\
\hline 242-A Evaporator & No; capacity not available \\
\hline Grout Facility & No; volume exceeds capacity; costs excessive \\
\hline
\end{tabular}

VOC - volatile organic compound 


\subsection{SCREENING OF REMOVAL ACTION TECHNOLOGIES}

The screening of removal action technologies and process options is conducted to eliminate technologies and process options that do not meet the ERA screening criteria. The following factors are used for this screening analysis:

- protectiveness

- timeliness

- technical feasibility

- institutional considerations.

The list of technologies and process options that were retained from Section 4.0 for analysis in the screening includes the following:

- $\quad$ Pump and Treat - Extraction

- $\quad$ extraction wells.

- $\quad$ Pump and Treat - Treatment

- ion exchange

- $\quad$ reverse osmosis

- $\quad$ supported liquid membrane

- flocculation

- sedimentation

- media filtration

- forced evaporation

- $\quad$ solidification/Stabilization.

- $\quad$ Pump and Treat- Treated Water Disposal

river discharge

- $\quad$ crib disposal

- passive solar evaporator.

- Vertical Barriers

- slurry wall

- grout curtain

- $\quad$ sheet pilings

- freeze wall

- $\quad$ permeable treatment beds.

- Hydraulic Control

extraction wells

extraction trenches.

In addition to these technologies, at the request of DOE's Richland Operations Office (RL), two innovative technologies are considered in screening: strontium biosorption and 
strontium solvent extraction with ionizable crown ethers. In their comments to the ERA project plan, the U.S. Environmental Protection Agency (EPA) also requested that wetlands bioassimilation be considered.

The screening of technologies and process options listed above is discussed in the following subsections.

\subsection{SCREENING CRITERIA}

Criteria for screening removal action technologies and process options are derived from the draft EPA guidance document Draft Engineering Evaluation/Cost Analysis Guidance for Non-Time-Critical Removal Actions (EPA 1987a). The criteria are described briefly as follows:

- $\quad$ Protectiveness

- Does the technology protect human health and the environment?

- Will the technology provide ultimate long-term mitigation of threats to human health and the environment?

- Are there any potential long-term threats posed by the technology?

What is the severity of these threats?

- Timeliness

- Can approval processes, contracting, mobilization, testing, and storage capacity be obtained on a timely basis?

- Are site-specific factors conducive to timely implementation?

- Technical feasibility

- Has the technology been proven in large, field-scale applications?

- Has the technology been used on similar site conditions, media, and contaminants?

- Institutional considerations

- Will the public accept the technology?

- Does the technology require acquisition of permits?

- Is the technology able to comply with essential chemical and location specific ARAR?

Does the technology require the cooperation of other agencies or organizations?

\subsection{TECHNOLOGY SCREENING}

This section documents the screening process for determining which technologies and process options should be developed into alternatives for detailed analysis. Each subsection provides a brief description of the technology or process option. The rationale for retaining 
or eliminating technologies and process options, based on evaluation against the screening criteria, is provided in Table 5-1.

\subsubsection{Pump and Treat - Extraction Wells}

Groundwater extraction 'wells are used to withdraw and isolate contaminated groundwater by manipulation of the hydraulic gradient (RAAS 1991). The extraction system may include a single well or multiple wells. The complexity of the design depends on the nature of the transporting medium, the depth of penetration of the contaminants, and the complexity of the geologic stratigraphy. The extraction process is used in conjunction with groundwater treatment and disposal.

\subsubsection{Pump and Treat - Treatment Process Options}

A wide range of primary and secondary treatment process options is considered for treating extracted contaminated water at the $\mathrm{N}$ Springs. Brief descriptions are provided below.

5.2.2.1 Ion Exchange. The ion exchange process adsorbs ionic contaminants in exchange for mobile ions of similar charge that are contained on organic resin beads or on inorganic materials such as zeolites. Both anions and cations, including radionuclides, can be removed from water by use of appropriate ion exchange media. The process involves pumping the contaminated water through vessels containing beds of ion exchange media. Configurations and combinations of ion exchangers containing either cation or anion media, or mixtures of the two, may be specified to operate either in series or parallel based on the volume of contaminated water to be treated. Media are chemically regenerated using concentrated salt or acid solutions that result in substantial volumes of secondary waste requiring treatment, usually by evaporation. Some media, such as synthetic zeolites, are used without regeneration. That is, the spent media are disposed of as solid waste after they become fully loaded with contaminants. The advantage of this type of media is that secondary liquid wastes are not generated.

Ion exchange is commercially available and proven. It is commonly used in DOE facilities and in the nuclear industry for a wide variety of processing and wastewater treatment applications (RAAS 1991).

5.2.2.2 Reverse Osmosis. The reverse osmosis process purifies contaminated water by application of high pressure which forces pure water through a semipermeable membrane but leaves the contaminants in a concentrated waste stream (EPA 1987b). The process is commercially available and highly effective for purifying water containing dissolved ions and radionuclides. However, a chief disadvantage is the generation of a substantial volume of secondary liquid waste that must be volume reduced and solidified prior to disposal.

5.2.2.3 Supported Liquid Membrane. The supported liquid membrane process is a variation of reverse osmosis. A liquid membrane consists of a micro-porous membrane 
containing an organic carrier held in place by capillary forces. Carriers are used to increase the selectivity of the membrane for specific constituents, potentially reducing the volume of secondary waste generated relative to reverse osmosis. Supported liquid membrane technology is currently in the experimental development phase. No commercial applications are known.

5.2.2.4 Flocculation. Flocculation is a proven physical process where inorganic contaminants are coagulated by the addition of chemicals (Freeman 1989). Flocculation is effective in removing suspended solids and is used in conjunction with sedimentation and/or filtration to remove the particles from water (DOE 1990).

5.2.2.5 Sedimentation. Sedimentation is a proven physical separation process whereby particles entrained in a liquid are separated by induced settling with gravitational or inertial forces (NRC 1981). For N Springs, it would be considered as a pretreatment step for removal of suspended particulates in the raw groundwater. Sedimentation produces a wet sludge as a secondary waste that must be dewatered or solidified and disposed.

5.2.2.6 Media Filtration. Media filtration is a common pretreatment step to remove solids from suspension by using media, such as diatomaceous earth or beds of sand (EPA 1987b). Depending upon particle sizes and quantities to be removed, cartridge-type filters containing fabric bags or porous metallic elements can also be used for filtration. Filtration produces $s$ condary solid waste requiring disposal.

5.2.2.7 Forced Evaporation. Forced evaporation is a proven process for reducing the volume of aqueous wastes. Forced evaporation would be considered for use in reducing the volume of secondary liquid wastes from reverse osmosis or ion exchange treatment. Vaporization of water is induced by raising the temperature of the waste stream mechanically by vapor recompression or in a heated evaporator. Vapor is then separated, condensed, and discharged. The concentrate requires further processing to render it a solid waste. This can be accomplished by drying or solidifying with cement or other solidification materials.

5.2.2.8 Solidification/Stabilization. This process is used to eliminate free liquids and immobilize contaminants so that the waste material can be land-disposed. The waste liquids or wet sludges are mixed with cement, fly ash, polymers or other suitable solidification material. The technology is well developed and commercially practiced for use in radioactive waste disposal. The technology would be considered for use in solidifying secondary wastes from reverse osmosis, ion exchange, filtration, and/or evaporation.

\subsubsection{Pump and Treat - Treated Water Disposal Options}

No practical treatment process is available for removing tritium from the $\mathrm{N}$ Springs groundwater. Thus several disposal options are considered for comparison to river discharge. Each is described briefly below.

5.2.3.1 River Discharge. This option provides a baseline for evaluation. Treated water containing tritium is discharged directly into the river via a pipeline and river outfall. 
5.2.3.2 Crib Disposal. Crib disposal is a subsurface water discharge method whereby water is allowed to percolate through the porous soil column into groundwater. The particles of the soil column essentially act as filters by adsorbing contaminants. Two crib disposal options are considered for N Springs: disposal at the N Area and disposal at the 200 Area. Crib disposal at the 200 Area allows sufficient travel time of tritiated water to the river so that the tritium would decay to very low levels by the time it reached the river. However, the chief disadvantage of this option is that a long and costly pipeline would have to be constructed to allow pumping the water to the 200 Area. Crib disposal to the $\mathrm{N}$ Area does not allow sufficient travel time for tritium decay. Both options would require a waiver of Tri-Party Agreement Milestone M-17 which requires the cessation of liquid effluent releases.

5.2.3.3 Reinjection. In this option, treated water is reinjected directly into the aquifer using conventional screened injection wells. Injected water would flow through the aquifer and into the river. Water would be injected at a location in the $\mathrm{N}$ Area that does not impact contaminated plume movement. The advantage of this option is that clean vadose zone soil is not contaminated with injected water.

5.2.3.4 Passive Solar Evaporation. Passive solar evaporation is a proven technology that uses large shallow surface impoundments or open tanks to evaporate water using solar radiation. The impoundments must be lined to prevent the water from percolating into the soil. Nets or other protection are also required to prevent animal access. The release of tritium to the air is a potential concern with passive evaporation. At present, treatment options for tritium in air are unavailable. Also, capture of emissions from a passive solar evaporator would be impracticable.

\subsubsection{Vertical Barriers}

Vertical barriers act as an obstruction to the groundwater pathway of contaminant migration. Because the flow of contaminants at $\mathrm{N}$ Springs is generally from the $1301-\mathrm{N}$ and $1325-\mathrm{N}$ cribs toward the river, a vertical barrier placed between these contaminant sources and the river may eliminate or substantially restrict the movement of contaminants to the river by leveling the groundwater flow gradient behind the wall. Strontium-90 has a tendency to bind to the soils. This tendency, combined with the decrease in the flow gradient, results in a decrease of strontium- 90 movement and thus a reduction in the flux to the river. In addition, some reduction in strontium- 90 concentrations occurs as a result of natural radioactive decay. This effect is limited, however, for this ERA because of the assumed timeframe of 10 years. Strontium -90 has a half-life nearly triple the proposed timeframe. A discussion of each type of barrier considered is given in the subsections below.

5.2.4.1 Slurry Wall. A slurry wall is a vertical barrier formed by emplacement of slurry in a vertical trench or boring. Conventional trench excavation uses backhoes or clamshell excavators; the slurry is used to shore the trench as excavation proceeds. New techniques for slurry wall construction have been commercialized whereby walls are built using deep soil mixing. In deep soil mixing, large-diameter augers are used to simultaneously drill, inject slurry, and mix slurry with soil materials. Slurry materials can include soil-bentonite 
or cement-bentonite mixes (slurry recipe would be determined through field testing). Slurry walls are typically designed for permeabilities of $10^{-7} \mathrm{~cm} / \mathrm{sec}$, but performance can be greater or less depending upon the type of slurry used, soil conditions, and placement techniques. The slurry wall technology has been proven on large, field-scale applications under similar circumstances and is commercially available.

\subsubsection{Grout Curtain. A grout curtain is a vertical barrier used to reduce or contain} groundwater flow. Grout curtains are formed by pressure injection of grout through pipes, augers, or beams that are inserted into the ground using a drill rig. The curtain is developed one "post" at a time along the containment boundary. Grout curtains are implementable and effective at waste sites. However, the presence of very coarse-grained and non-uniform materials in the Hanford formation increases the uncertainty in the proper positioning of the grout posts and in the integrity of grout penetration and coverage. The high permeability soils would inhibit the formation of a grout curtain by reducing the ability to control continuity of grout placement.

5.2.4.3 Sheet Pilings. Sheet pilings are vertical barriers constructed of materials such as wood, precast concrete, or steel. The walls, or sheets, are typically assembled at the surface and then driven into the ground a few feet at a time over the entire length of the wall with a vibratory or drop hammer.

Sheet pilings are not feasible at $\mathrm{N}$ Springs because of the presence of large boulders and rocky soils that would cause damage or deflection of the walls. This damage or deflection would result in unpredictable wall integrity.

5.2.4.4 Freeze Wall. A freeze wall, or cryogenic wall, is a vertical barrier formed by freezing interstitial water within the soils. The freeze wall is formed by circulating coolant through steel pipes installed in the ground. Pipes are installed using conventional drilling techniques. To facilitate an effective frozen wall, the pipes must be installed on a relatively close spacing $(6-7 \mathrm{ft})$. Freeze walls have been used successfully in special construction applications where temporary groundwater barriers were necessary. However, this technology is considered innovative for use in hazardous waste management as it has not yet been applied in site remediation (Dash 1991, EPA 1990).

The implementability of the freeze wall is very difficult and costly because of the need for a large number of holes. A vendor estimated that approximately 800 holes, $120 \mathrm{ft}$ deep, would be required for a $2800-\mathrm{ft}$ wall at $\mathrm{N}$ Springs. Using cable tool or sonic drilling would require over 40 rig-years for installation and would incur costs over $\$ 80 \mathrm{M}$. Thus this technology is neither technically feasible nor cost effective for Hanford application.

\subsubsection{Permeable Treatment Beds. Permeable treatment beds are excavated trenches} placed perpendicular to groundwater flow and filled with an appropriate material to treat the plume of contamination as it flows through the material (EPA 1985). Permeable treatment beds are aiso referred to as permeable barriers (EPA 1990). The technology category is also referred to as in situ sorption (RAAS 1991). Possible treatment materials or adsorbents include activated carbon, agricultural residues, clays, zeolites, glauconitic greensand, and limestone (RAAS 1991). In the case of N Springs, zeolites and glauconitic greensands, 
which are high surface area cation exchange materials, would probably be the most appropriate materials for removing strontium- 90 .

The technology is applicable to relatively shallow groundwater tables containing a plume. The application of permeable treatment beds at hazardous waste sites has not been performed (EPA 1985, EPA 1990), although bench- and pilot-scale testing for specific applications have been undertaken (EPA 1990). The DOE Office of Technology Development has proposed that research and development (R\&D) programs on permeable barriers be included in the In Situ Remediation Integrated Program (Peterson 199).

A major drawback in using permeable treatment beds is that the materials may become fully loaded with contaminants and other adsorbed constituents and may lose their adsorption characteristics (RAAS 1991). In addition, permeable barriers may become clogged with precipitates necessitating periodic removal, treatment and/or disposal as hazardous/radioactive waste. Therefore, this technology should be considered only as a temporary containment measure (RAAS 1991).

Because permeable treatment beds have not been proven in hazardous waste field applications, and therefore no performance data exist, the degree of protectiveness and the technical feasibility of this technology at N Springs are uncertain.

\subsubsection{Hydraulic Control}

5.2.5.1 Extraction Wells. Extraction wells, described in Section 5.2.1, are used for hydraulic control by placement upgradient from the contaminated plume. By pumping groundwater upgradient from the contaminated plume, the natural flow is intercepted so that the gradient in the area of the contamination is lowered and the flow of groundwater towards the river is slowed. This reduction in flow reduces the rate of contaminant transport into the river. The hydraulic control wells are placed sufficiently upgradient from the plume so the contaminated water is outside the radius of influence of the wells. Thus the water pumped by upgradient control wells is not contaminated and can be discharged to the river without treatment.

5.2.5.2 Extraction Trenches. Extraction trenches are sometimes used for hydraulic control instead of a line of extraction wells. The trench, which is constructed with permeable material, provides a subsurface drain by which the flow of groundwater can be intercepted. Pumps are used to remove the groundwater that flows into the trench. Trenches are more beneficial than wells where the groundwater and the contamination are shallow or where the geologic conditions would require a large number of closely spaced wells. Neither is the case for $\mathrm{N}$ Springs, because the $\mathrm{N}$ Area groundwater is deep and the aquifer is porous so that wells would not be closely spaced. 


\subsubsection{Miscellaneous Technologies}

At the request of DOE-RL, selected innovative technologies were evaluated for their potential application in the N Springs ERA.

5.2.6.1 Strontium Biosorption. Laboratory-scale studies have been performed at Oak Ridge National Laboratory (ORNL) on the adsorption of strontium from wastewater using immobilized microorganisms (Faison et al. 1990, Watson et al. 1990, Watson et al. 1989). The experiments were performed using laboratory glass packed-columns containing microbial cells (bacteria) immobilized on beads of a gelatin matrix. The experiments concluded that microbial cells can adsorb strontium from dilute solutions.

While the laboratory studies performed to date show promise, this innovative technology is in the very early siages of development. The potential advantage of this technology relative to conventional ion exchange media is that the microbial media may be less expensive, more selective for strontium, and have higher loading capacities; however, these advantages have yet to be demonstrated.

Because this technology is not yet sufficiently developed, it cannot be shown to meet the ERA selection criteria of timeliness, protectiveness, and technical feasibility. Therefore, this technology will not be considered further for the N Springs ERA.

5.2.6.2 Solvent Extraction With Ionizable Crown Ethers. Laboratory experiments have been performed by researchers at the University of Idaho on the extraction of strontium-90 and other radionuclides from aqueous phase into chloroform using a new class of selective chelating agents called ionizable crown ethers (Wai and Du 1990, Tang and Wai 1989, Tang and Wai 1988). The published papers discuss results of work aimed at understanding the chemistry of the process and do not delve into applications.

From the information available, it is apparent that the technique is in the very early research stage. Much more research and development remain to demonstrate practical application. Thus, because this technology does not meet the ERA selection criteria, it will not be considered further for N Springs.

5.2.6.3 Wetlands Bioassimilation. Wetlands bioassimilation refers to the utilization of wetlands plants to uptake and sccumulate contaminants such as metals and radionuclides contained in wastewater. This innovative technology would be used in combination with groundwater extraction; the water would be pumped from the aquifer and discharged to artificial wetlands onsite in which plants would be grown and harvested. Harvested plants containing metals and radionuclides would then be permanently disposed by compaction and burial as solid waste.

Wetlands have been used for control of urban runoff. There is evidence that some metals are biologically accumulated in plants grown where contaminants exist. However, no performance data exist on effectiveness or secondary effects of this technique. While the concept may have merit, more research is needed before the concept could be considered for hazardous site remediation. 


\begin{tabular}{|c|c|c|c|c|c|}
\hline \multirow[t]{2}{*}{ Process Option } & $\begin{array}{l}\text { Technical } \\
\text { Feasibility, } \\
\text { Timeliness }\end{array}$ & Technical Feasibility & Protectiveness & $\begin{array}{c}\text { Technical Feasibility, } \\
\text { Institutional } \\
\text { Considerations } \\
\end{array}$ & \multirow{2}{*}{$\begin{array}{l}\text { Retain Process } \\
\text { Option for } \\
\text { Detailed } \\
\text { Analysis? }\end{array}$} \\
\hline & $\begin{array}{l}\text { Is Process Option } \\
\text { Commercially } \\
\text { Available? }\end{array}$ & $\begin{array}{l}\text { Has Process Option } \\
\text { Been Used in Similar } \\
\text { Circumstances? }\end{array}$ & $\begin{array}{l}\text { Is Process Option } \\
\text { Sufficiently Effective? }\end{array}$ & $\begin{array}{l}\text { Is Process Option } \\
\text { Implementable? }\end{array}$ & \\
\hline \multicolumn{6}{|c|}{ Pump and Treat - Extraction } \\
\hline Extraction Wells & Yes & Yes & Yes & Yes & Yes \\
\hline \multicolumn{6}{|c|}{ Pump and Treat - Treatment } \\
\hline Ion Exchange & Yes & Yes & Yes & Yes & Yes \\
\hline Reverse Osmosis & Yes & Yes & Yes & Yes & Yes \\
\hline $\begin{array}{l}\text { Selective Liquid } \\
\text { Membrane }\end{array}$ & No & No & Uncertain & Uncertain & No \\
\hline Flocculation & Yes & Yes; for pretreatment & Yes; for pretreatment & Yes & Yes $^{(1)}$ \\
\hline Sedimentation & Yes & Yes & Yes & Yes & Yes $^{(1)}$ \\
\hline Media Filtration & Yes & Yes; for pretreatment & Yes; for pretreatment & Yes & Yes $^{(1)}$ \\
\hline Forced Evaporation & Yes & $\begin{array}{l}\text { Yes; for secondary } \\
\text { waste treatment }\end{array}$ & $\begin{array}{l}\text { Yes; for secondary } \\
\text { waste treatment; } \\
\text { potential for tritium } \\
\text { release to air* }\end{array}$ & Yes & Yes $^{(2)}$ \\
\hline $\begin{array}{l}\text { Solidification/ } \\
\text { Stabilization }\end{array}$ & Yes & Yes & Yes & Yes & Yes $^{(3)}$ \\
\hline \multicolumn{6}{|c|}{ Pump and Treat - Disposal Options } \\
\hline Crib Disposal & Yes & Yes & Yes & Yes & Yes \\
\hline River Discharge & Yes & Yes & Yes & Yes & Yes \\
\hline Reinjection & Yes & Yes & Yes & Yes & Yes \\
\hline
\end{tabular}




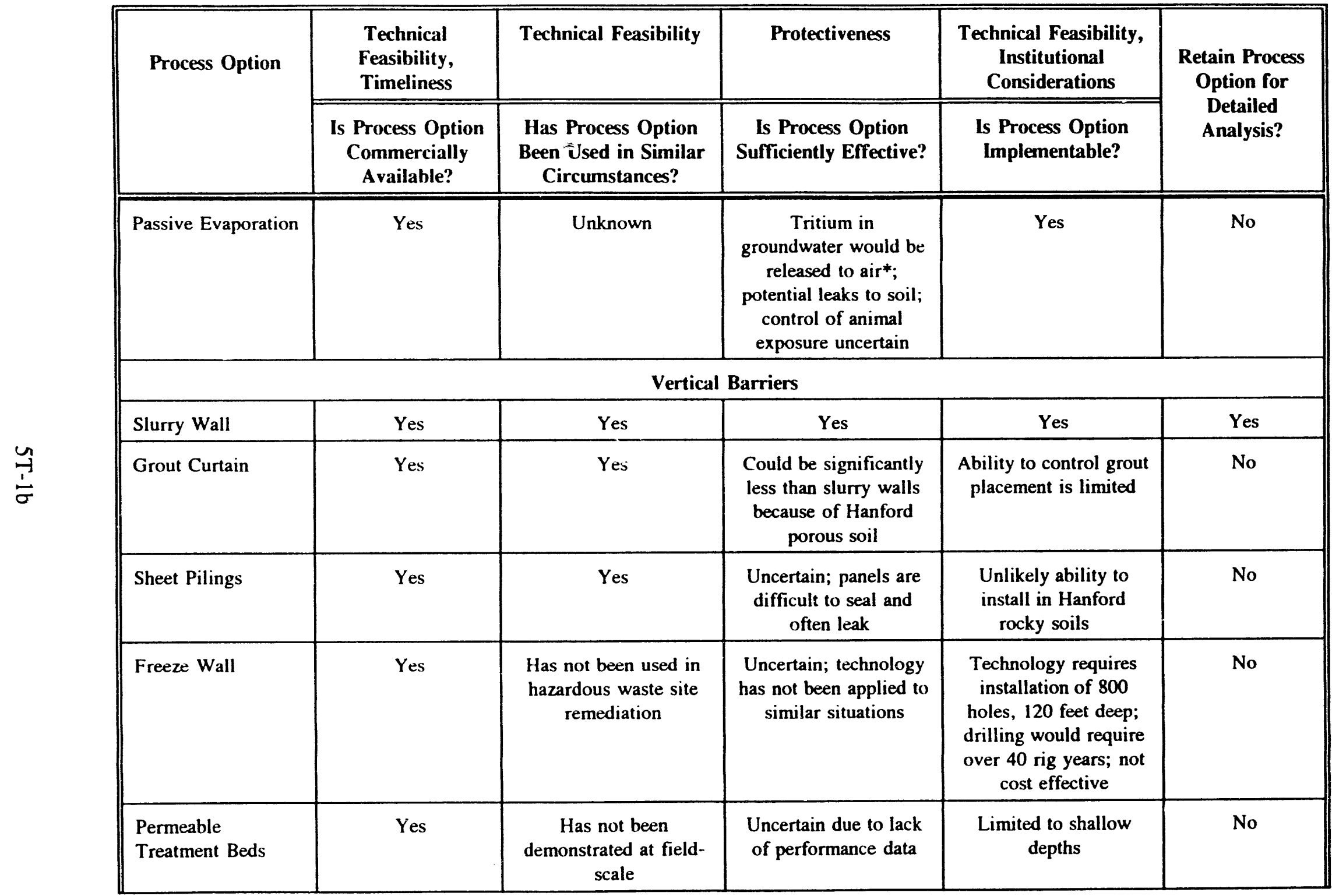




\begin{tabular}{|c|c|c|c|c|c|}
\hline \multirow[t]{2}{*}{ Process Option } & $\begin{array}{l}\text { Technical } \\
\text { Feasibility, } \\
\text { Timeliness }\end{array}$ & Technical Feasibility & Protectiveness & $\begin{array}{c}\text { Technical Feasibility, } \\
\text { Institutional } \\
\text { Considerations } \\
\end{array}$ & \multirow{2}{*}{$\begin{array}{l}\text { Retain Process } \\
\text { Option for } \\
\text { Detailed } \\
\text { Analysis? }\end{array}$} \\
\hline & $\begin{array}{l}\text { Is Process Option } \\
\text { Commercially } \\
\text { A vailable? }\end{array}$ & $\begin{array}{l}\text { Has Process Option } \\
\text { Been Used in Similar } \\
\text { Circumstances? }\end{array}$ & $\begin{array}{l}\text { Is Process Option } \\
\text { Sufficiently Effective? }\end{array}$ & $\begin{array}{l}\text { Is Process Option } \\
\text { Implementable? }\end{array}$ & \\
\hline \multicolumn{6}{|c|}{ Hydraulic Control } \\
\hline Extraction Wells & Yes & Yes & Yes & Yes & Yes \\
\hline Extraction Trenches & Yes & $\begin{array}{l}\text { Used in shallow } \\
\text { applications }\end{array}$ & Yes & $\begin{array}{l}\text { Depth to groundwater } \\
\text { makes this } \\
\text { impracticable }\end{array}$ & No \\
\hline \multicolumn{6}{|c|}{ Miscellaneous } \\
\hline $\begin{array}{l}\text { Strontium } \\
\text { biosorption }\end{array}$ & No & No & $\begin{array}{l}\text { Unknown; no } \\
\text { performance data } \\
\text { available }\end{array}$ & $\begin{array}{l}\text { Unknown; no } \\
\text { performance data } \\
\text { available }\end{array}$ & No \\
\hline $\begin{array}{l}\text { Solvent extraction } \\
\text { with ionizable } \\
\text { crown ethers }\end{array}$ & No & No & $\begin{array}{l}\text { Unknown; no } \\
\text { performance data } \\
\text { available }\end{array}$ & $\begin{array}{l}\text { Unknown; no } \\
\text { performance data } \\
\text { available }\end{array}$ & No \\
\hline $\begin{array}{l}\text { Wetlands } \\
\text { bioassimilation }\end{array}$ & No & No & $\begin{array}{l}\text { Unknown; no } \\
\text { performance data } \\
\text { available }\end{array}$ & $\begin{array}{l}\text { Unknown; no } \\
\text { performance data } \\
\text { available }\end{array}$ & No \\
\hline
\end{tabular}

Notes: 1. Consider as an option for ion exchange or reverse osmosis pretreatment to remove suspended solids

2. Consider as an option for ion exchange or reverse osmosis liquid waste treatment for volume reduction

3. Consider as an option for ion exchange or reverse osmosis liquid waste solidification treatment

* No current treatment options for practicable removal of tritium from air are available. 


\subsection{DETAILED ANALYSIS OF REMOVAL ACTION ALTERNATIVES}

The alternative technologies that have passed the initial screening must undergo a more detailed analysis to select the removal action alternative to be implemented. Each alternative is evaluated with respect to the four selection criteria:

- technical feasibility

- cost considerations

- institutional considerations

- $\quad$ environmental impacts.

Each of these criteria is described briefly as follows (EPA 1987a):

\section{Technical feasibility}

- $\quad$ ability to comply with ARAR

- effectiveness in reducing toxicity, mobility, or volume of contamination

- demonstrated performance and reliability under similar conditions

- useful life

- constructability

- $\quad$ operating and maintenance (O\&M) requirements

- environmental effects on performance

- $\quad$ sensitivities and uncertainties.

\section{Cost considerations}

- $\quad$ capital costs

- O\&M costs

- $\quad$ present worth

- cost uncertainties.

\section{Institutional considerations}

- $\quad$ ability to achieve removal action objectives

- regulatory concerns about the technology

- permitting requirements

- $\quad$ safety

- timeliness.

\section{Environmental Impacts}

- impacts of the removal action on

- topography and surface drainage

- geology

- $\quad$ soils

- $\quad$ surface water hydrology and quality 


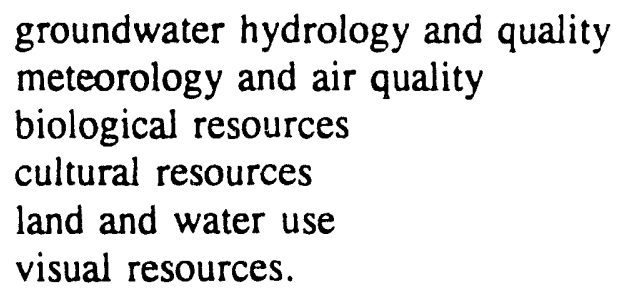

Removal action technologies that passed screening (Section 5.0) are assembled into alternatives for evaluation and comparative analysis. The alternatives are assembled into major technology types (e.g., pump and treat, vertical barriers). The pump and treat alternative includes numerous suboptions for number and location of pumping wells, treatment processes, and treated water disposal schemes. Not all possible combinations of extraction, treatment, and disposal options are evaluated because of the cumbersome nature of the process and lack of benefit of examining all permutations. Instead, the pump and treat technology options are evaluated in three modules: pumping options, treatment options, and treated water disposal options. Specific options from each module are then combined to allow evaluation of alternatives that span the full range of benefits and cost. Once alternatives are compared, selection of a preferred alternative is made by assessing the advantages, disadvantages, uncertainties, and sensitivities of each option and arriving at a selection that is cost-effective for the benefit achieved.

The list of alternatives evaluated in detail is given as follows:

Alternative 1 - No Action

- Continued groundwater monitoring and access control.

Alternative 2 - Pump and Treat

- $\quad$ Pumping Options:

- $\quad$ five wells

- three wells.

- Treatment Options:

- ion exchange

- reverse osmosis.

- Treated Water Disposal Options:

- river discharge

- new $N$ Area crib

- $\quad$ N Area injection wells

- new 200 Area crib.

Alternative 3 - Vertical barrier

- $\quad$ Slurry Wall. 


\section{Alternative 4 - Hydraulic control}

- Upgradient pumping wells.

All alternatives include continued groundwater monitoring and access control. For purposes of detailed analysis, a 10-year project life is assumed because the removal action is considered an interim response until a final remedy is implemented for the 100-NR-2 operable unit. An objective of this ERA is to implement an alternative that contributes to the efficient performance of the final remedial action. While the ERA does not have to comply with the cost and time limitation defined under CERCLA for fund-financed actions, the ERA should be reevaluated in the future for possible conversion to an IRM.

The cost estimates that support the evaluations provide a level of accuracy of $+50 \%$ to $-30 \%$, which is typical of the types of estimates performed for CERCLA FS. Wherever possible, common assumptions are used for estimates and all costs are given in 1993 dollars. Cost estimating details, including assumptions and sources of costs, are provided in Appendix A. Caution should be used in interpreting the estimates, because the intent at this stage of evaluation is to assess costs in relative terms as opposed to absolute terms. That is, the costs should not be considered for their absolute accuracy because more definition and design are needed, especially in assigning indirect costs associated with Hanford installations. However, in relative terms, the costs are sufficiently accurate to make comparisons and judgements regarding the cost-effectiveness of alternatives. The cost uncertainties associated with each alternative or option are discussed in the specific sections where sufficient information is available to evaluate uncertainties.

The general approach to cost estimation assumes that removal systems for $\mathrm{N}$ Springs are treated as environmental projects, not as installations of permanent nuclear facilities. Where noted, Hanford labor rates have been used in the labor cost estimate, and additional costs associated with handling radioactively contaminated materials have been considered, where appropriate. In general, the cost estimates reflect an assumption that the level of design and system complexity are minimized to provide systems which, while offering quality in construction and implementation, are consistent with the objectives of an ERA.

The monitoring program discussed for the no action alternative is also assumed to apply to the other alternatives being evaluated. The monitoring program may be expanded to include new wells to monitor the performance of the ERA. Specification of changes to the current monitoring program would be made in the ERA design phase.

The following subsections document the detailed analysis of the four alternatives listed above. 


\subsection{ALTERNATIVE 1 - NO ACTION}

\subsubsection{Description}

The no action alternative implies no removal action: however, groundwater monitoring and institutional access/administrative controls would continue through the assumed period of performance (10-year project life). This alternative will not reduce the flow of contaminants to the river through the springs. However, because the principal contaminants are radionuclides, they will eventually attenuate through radioactive decay. Soil adsorption is also a factor in the eventual release of strontium-90 to the river. As strontium-90 contaminated groundwater travels through the soils, the contaminant is adsorbed and desorbed in the soil. The net effect will be long-term slow release of strontium- 90 to the groundwater.

The monitoring program presently in place will continue. The program consists of the following elements:

- yearly monitoring of the $\mathbf{N}$ Springs

- $\quad$ quarterly groundwater well monitoring

- bi-weekly radionuclide effluent analysis of $\mathrm{N}$ Springs discharges to the river

- continuous dosimeter surveys along the perimeter fences and ropes

- $\quad$ quarterly radiation surveys along the outer perimeter fences of the cribs/trenches

- annual radiation surveys around the inner perimeter rope of both trenches

- $\quad$ continuous air sampling with monthly analysis.

Connelly et al. (1991) developed a simulation of the groundwater flow and strontium-90 transport in the N Springs area. The PORFLO-3 groundwater flow and transport model was used for this modeling effort. The model simulates the groundwater flow system and contaminant transport utilizing user inputs for groundwater flow and contaminant transport parameters (e.g., hydraulic conductivity, groundwater gradient, contaminant sorption coefficient, etc.). As with all models, this model is an approximation of the groundwater flow and contaminant transport at N Springs.

Assumptions regarding the geometry of the model, such as source dimensions, were generalized due to internal model constraints. The groundwater flow portion of the model was calibrated by comparing simulated arrival times of a nonsorbed radionuclide and water table elevations in July 1969 to observed field data reported in Crews and Tillson (1969). The transport portion of the model was calibrated to match the strontium- 90 concentrations observed at the N Springs. The calibration was ended in 1974 when it appeared that the 
model was predicting the values actually observed at $\mathrm{N}$ Springs. The simulation estimated an arrival time of strontium-90 that was 4 years less than that observed and, therefore, overpredicted the strontium- 90 concentration.

Following calibration, the PORFLO-3 model was run to predict strontium-90 concentrations in the future. Using 1990 as the base case, strontium-90 concentrations at the river gradually decrease from $6,200 \mathrm{pCi} / \mathrm{L}$ in 1990 to about $1,000 \mathrm{pCi} / \mathrm{L}$ in 10 years. A plot of groundwater levels and strontium-90 concentrations between the 1301-N LWDF and the N Springs for the year 2002 is shown on Figure 6-1. Comparisons of actual strontium-90 concentrations observed at N Springs, during 1990 and 1993, with those predicted by Connelly et al. (1991), show that the model does predict consistent concentrations at the $N$ Springs. The concentration gradient near the river is high, probably reflecting river water dilution. Concentrations upgradient from the $\mathrm{N}$ Springs appear to be predicted at concentrations higher than found in actual groundwater samples. The PORFLO-3 model assumes a homogeneous and isotropic aquifer system when in fact it is not. The variability in predicted versus actual groundwater strontium- 90 concentrations may be the result of heterogeneities in aquifer properties and variation in sorptive/desorptive characteristics of the aquifer material.

Additional details of the model setup, calibration, and results are found in Connelly et al. (1991). The strontium-90 distribution shown on Figure 6-1 does not exactly match what would be expected based on the groundwater levels shown on the same figure. This is because of the very large volumes of water discharged from 1964 to 1991 created an artificial groundwater mound that distributed the strontium-90 radially around the disposal facility. The figure reflects this distribution. Over this 12-year period, the model predicts the total strontium-90 flux at $33 \mathrm{ft}$ from the river, with no abatement action taken, to be 12.6 Ci (see Table 6-1). Connelly et al. (1991) states the conclusion of the modeling effort as follows:

"...without additional discharges to the LWDF, the plume should remain where it currently is and decay with time."

This model should only be used as an indicator of general groundwater flow and contaminant transport, such as how far does the plume move with time or does one alternative restrict groundwater flow better than another. The strontium-90 concentrations predicted by the model represent concentration estimates for the groundwater; they should not be taken as absolute predictions of subsurface concentrations but rather as indicators. The model generalized many of the vadose zone and aquifer characteristics. Uncertainties in the natural hydrogeologic system for such physical parameters as the sorption coefficient and longitudinal and transverse dispersivities, and aquifer properties such as hydraulic conductivity, heterogeneities, anisotropies result in uncertainty in the absolute predictive ability of the model.

Inclusion of this option in the evaluation satisfies the National Contingency Plan (NCP) requirement that a no action alternative be evaluated as a baseline to which all other alternatives are compared. 


\subsubsection{Technical Feasibility}

Existing administrative and institutional controls in the $100 \mathrm{~N}$ Area include site security and access restrictions designed to minimize human exposure to contamination. Currently, the only potential human exposure to contaminated groundwater is in the immediate vicinity of the seeps and springs along the riverbank. While access controls may be effective in reducing human exposure, the level of security is not sufficient to prevent members of the public from intentionally entering the area. Institutional controls also do not prevent exposure to environmental receptors, such as wildlife. The existing monitoring program is considered effective in continually assessing potential human health and environmental effects. Evaluation of the no action alternative against other technical feasibility criteria is given in Table 6-2.

\subsubsection{Cost Considerations}

Costs associated with institutional controls and continued groundwater monitoring are not included in this analysis because these programs are already in place and because these are common to all the alternatives being evaluated. Thus this alternative is considered to have a zero baseline cost ior comparative evaluation purposes.

\subsubsection{Institutional Considerations}

The evaluation of institutional considerations for the no action alternative is summarized in Table 6-3.

\subsubsection{Environmental Impacts}

The evaluation of environmental impacts for the no action alternative is summarized in Table 6-4.

\subsection{ALTERNATIVE 2 - PUMP AND TREAT}

\subsubsection{Description}

The pump and treat alternative consists of two groundwater extraction options, two treatment process options, and four treated water disposal options. Each of these options is described in the subsections below. An overall process flow diagram for the pump and treat system is presented in Figure 6-2.

6.2.1.1 Pumping Options. Three- and five-well systems are considered for the pump and treat alternative to optimize the cost-benefit. The evaluation determines the relative effectiveness of each pumping option in reducing the contaminant flux to the river. The 
pumping options were chosen because they represent a reasonable estimate of the system requirements. It is recognized that other options of well numbers and locations may also prove effective. This optimization will be addressed in the design phase if pump and treat is the chosen alternative.

6.2.1.1.1 General Modeling Approach. In both pumping options, the wells are placed $100 \mathrm{ft}(30 \mathrm{~m})$ from the river. The actual position of the wells relative to the river will be determined during the design phase, if pump and treat is the chosen alternative. The well position is a balance between the need to pump water with as little river water contribution as possible and the need to reduce the volume of water requiring treatment to as low as possible.

The effectiveness of each pumping case is evaluated using the PORFLO-3 groundwater flow model. This model is the same as discussed for the no action alternative above.

Westinghouse Hanford Company (WHC) (1991) evaluated the three- and five-well pumping alternatives using both analytical and numerical methods. The objective of the WHC (1991) study was to reduce or eliminate the majority of the strontium-90 flux to the river. This was accomplished by developing an extraction well capture zone configuration to encompass the strontium- 90 plume within the $1,000 \mathrm{pCi} / \mathrm{L}$ concentration contour and to intersect the Columbia River. The number of wells, well spacing, and flow rate were adjusted to create a capture zone with minimization of river water contribution, which contributes to the total water requiring treatment. Based on analytical methods, a multiple well system consisting of five extraction wells, each pumping between 60 and $100 \mathrm{gal} / \mathrm{min}$ ( 330 and $550 \mathrm{~m}^{3} /$ day), spaced 360 to $375 \mathrm{ft}$ apart would accomplish the above objective.

The above extraction system and a three-well system were then modeled using the PORFLO-3 model simulation developed by Connelly et al. (1991) to determine the effects of pumping on strontium-90 release to the river. The two extractic 7 well scenarios modeled were:

- 3 extraction wells, each pumping at $50 \mathrm{gpm}\left(270 \mathrm{~m}^{3} /\right.$ day), total discharge of $150 \mathrm{gal} / \mathrm{min}\left(820 \mathrm{~m}^{3} /\right.$ day $)$, spaced $720 \mathrm{ft}(220 \mathrm{~m})$ apart

- 5 extraction wells, each pumping at $60 \mathrm{gpm}\left(330 \mathrm{~m}^{3} /\right.$ day $)$, total discharge of $300 \mathrm{gal} / \mathrm{min}\left(1,640 \mathrm{~m}^{3} /\right.$ day $)$, spaced $375 \mathrm{ft}(114 \mathrm{~m})$ apart.

The extraction wells in both scenarios were placed $100 \mathrm{ft}(30 \mathrm{~m})$ from the river and within the $1,000 \mathrm{pCi} / \mathrm{L}$ strontium-90 contour. Results of the modeling for the five-well system at year ten are shown on Figure 6-3.

The PORFLO-3 model provided estimates of the annual and cumulative strontium- 90 flux across two vertical counting sections located $33 \mathrm{ft}(10 \mathrm{~m})$ and $100 \mathrm{ft}(30 \mathrm{~m})$ from the river. The sections were $2,800 \mathrm{ft}(853 \mathrm{~m})$ long and summed a saturated zone $33 \mathrm{ft}(10 \mathrm{~m})$ high. The annual and cumulative mass flux, estimated by the PORFLO-3 model are 
presented on Table 6-1. Positive values indicate a net strontium-90 mass movement toward the river and negative values indicate net mass movement toward the wells.

The results of the PORFLO-3 modeling for both the three- and five-well extraction systems indicate that they are both effective in reducing strontium- 90 flux to the river, the five-well system being approximately 10 times more effective. The five-well system reduces approximately $96 \%$ of the strontium-90 flux at the $33-\mathrm{ft}$ flux zone as compared to the no action alternative. The three-well system reduces the flux at this same zone approximately $67 \%$ (see Table 6-1).

Uncertainties associated with the above analysis included: hydraulic conductivity, hydraulic gradient, and contaminant distribution, both lateral and vertical. Also, the model considered only a 2,800-ft summation zone; the effects on either end of this zone were not defined. These uncertainties can effect the number of wells required, the location of wells, and the pumping rates. Prior to design additional field testing and modeling are required to reduce these uncertainties.

6.2.1.2 Treatment Options. Two treatment options are evaluated in detail for application to treatment of contaminated N Springs groundwater: ion exchange and reverse osmosis. Each treatment option is described in the following paragraphs.

6.2.1.2.1 Ion Exchange. A conceptual process flow diagram of an ion exchange system for treatment of $\mathrm{N}$ Springs groundwater is given in Figure 6-4. A brief discussion is presented in the following paragraphs.

Groundwater pumped from the extraction well system is collected in a flow equalization tank, which is used to ensure uniform contaminant concentrations in the water fed to the ion exchange system and to provide surge capacity. The water from the tank is pumped to a pretreatment filtration system to remove particulates and suspended solids. These solids must be removed to prevent fouling of the ion exchange beds. The filters are precoat type, which generate small volumes of low-level radioactive solid waste requiring disposal.

Three ion exchange columns in parallel (two active columns and a maintenance back-up) are used to remove the strontium-90. Each column contains two types of exchange media: an organic resin for removal of anionic species such as cobalt colloids and a chabazite zeolite for removal of the strontium-90. The zeolite media will also remove calcium, nonradioactive magnesium, strontium, and other minerals in the groundwater. Alkali metals such as potassium and sodium, however, are not significantly adsorbed on either media. The ion exchange media are not regenerated but are periodically removed from the exchange columns and replaced with fresh media. The media are removed hydraulically into a dewatering tank followed by load-out into disposal containers, such as drums or disposal boxes. Fresh media are pneumatically transferred into the ion exchange vessel. The treated water then flows to the disposal system (see Section 6.2.1.3). Spent 
media and filter wastes are estimated to be about $8,000 \mathrm{ft}^{3}\left(225 \mathrm{~m}^{3}\right)^{1}$ per year for a system treating $300 \mathrm{gal} / \mathrm{min}(1,135 \mathrm{~L} / \mathrm{m})$ of groundwater (the five-well system). Solid wastes would be disposed as low-level radioactive solid wastes.

The type of system described above has been used in nuclear power plant applications and has been recently pilot tested at ORNL (Robinson et al. 1990) for treatment of a wastewater that is very similar in composition to the N Springs groundwater. Oak Ridge National Laboratory presently treats a $150-\mathrm{gal} / \mathrm{min}$ wastewater stream with a regenerative ion exchange system. However, they have found that evaporation of the secondary waste is costly (about $\$ 0.5 \mathrm{M} / \mathrm{yr}$ total disposal cost) (Robinson et al. 1990). The pilot tests using nonregenerative chabazite zeolites showed potential disposal cost savings of about $80 \%$. Oak Ridge National Laboratory plans to install the zeolite-based system at their facility in the future.

The ORNL system was designed to remove the strontium-90 to $300 \mathrm{pCi} / \mathrm{L}$ to meet the requirements of DOE Order 5400.5; the pilot testing verified that those levels could be met. However, the N Springs target performance level is the proposed strontium-90 MCL of $42 \mathrm{pCi} / \mathrm{L}$. The vendor of the proposed system was unwilling to state that the ion exchange system could meet the desired performance level without treatability testing. The vendor stated that the proposed system could produce water $<270 \mathrm{pCi} / \mathrm{L}$. Therefore, the ion exchange system performance remains a technical uncertainty at this point.

Because essentially all of the dissolved material removed in the ion exchange columns is other than the target contaminant strontium-90, the size of the treatment system and the generation of secondary waste will vary proportionately to the volume of groundwater treated. For example, the treatment system for the three-well pumping scenario $(150 \mathrm{gal} / \mathrm{min})$ is $50 \%$ the size of the five-well treatment system $(300 \mathrm{gal} / \mathrm{min})$ and generates correspondingly less secondary waste.

6.2.1.2.2 Reverse Osmosis. A conceptual process flow diagram for a reverse osmosis groundwater treatment system is shown in Figure 6-5.

A flow equalization/surge tank receives groundwater from the pumping wells. The water is pretreated by filtration using 5 micron and 0.5 micron cartridge filters in series to remove suspended solids. The $\mathrm{pH}$ of the groundwater is then adjusted to 5.0 using acid, which prevents precipitation of salts as the concentration of carbonates is increased in the reject stream. Formation of carbonate and sulfate salts will clog the membranes and greatly reduce operating efficiency. Sodium hexametaphosphate is also added to inhibit crystallization of other types of salts that may form as concentration increases in the reject stream.

The chemically treated groundwater is pumped at high pressure into a reverse osmosis unit where processing will produce a concentrated waste stream containing the bulk of the dissolved solids and a stream consisting of demineralized water. The membranes are

\footnotetext{
'Based on assumed total disso!ved solids in groundwater of $150 \mathrm{ppm}$, a $50 \%$ solid bottoms stream, and $100 \%$ volume increase for solidification.
} 
typically either spiral wound into a cylindrical configuration or are fabricated into hollow fibers. The membranes provide a pore size in the range of one to ten angstroms $(0.0001$ 0.001 microns).

The purified water stream (permeate) is discharged via the disposal system (see Section 6.2.1.3), while the concentrate must be processed further for volume reduction. The concentrated waste stream represents about $10 \%$ of the feed stream, although the exact quantity of waste is subject to determination in a treatability study. It is also uncertain whether the reverse osmosis system can meet the treatment performance requirement of $42 \mathrm{pCi} / \mathrm{L}$. This is subject to determination in a treatability study.

The concentrated waste stream is volume-reduced by evaporation. A single vapor recompression evaporator (electrically heated) is specified for this application (this evaporator is assumed hcre because of energy efficiency; the actual type of evaporator and power source would be determined in the design phase). The clean condensed vapor from the evaporator is discharged with the reverse osmosis permeate. The evaporator-bottoms stream, which is about $50 \%$ solids, is solidified in a Portland cement grout. Based on current groundwater data, the bottoms stream can likely be disposed as a low-level radioactive solid waste. For a $300 \mathrm{gal} / \mathrm{min}$ groundwater treatment system, the volume of grouted waste is estimated to be about $8,000 \mathrm{ft}^{3}$ per year.

The options of disposing liquid wastes to the existing double-shell tanks (DST), the 242-A evaporator, or both were considered but rejected. The volume of liquid waste would result in an unacceptably large increase in DCr ...astes. The 242-A evaporator is not currently operating and is considered unava processing any wastes other than the existing tank farm wastes.

6.2.1.3 Treated Water Disposal Options. Treated groundwater from the processes described in Section 6.2.1.2 above will still contain levels of tritium that exceed ARAR (the drinking water MCL for tritium is $20,000 \mathrm{pCi} / \mathrm{L}$ and the proposed $\mathrm{MCL}$ is $60,900 \mathrm{pCi} / \mathrm{L}$ ). The tritium levels in the grounc vater are not reduced by either treatment process. Currently, there is no known treatment process for removing tritium that can oe practically applied to groundwater.

Based on 1991 data, the average tritium concentration in the area of the pumping wells is about $51,000 \mathrm{pCi} / \mathrm{L}$ (Schmidt et al. 1992). Upon pumping, the tritium concentrations would likely increase because the center of mass of the tritium plume is still upgradient of the proposed pumping well location(s). Based on 1993 data, the maximum observed concentration of tritium was $80,900 \mathrm{pCi} / \mathrm{L}$, located just downgradient of the $1325-\mathrm{N}$ crib. This could be considered as a conservative maximum concentration that may be expected in an extraction well. Using the proposed $\mathrm{MCL}$ of $60,900 \mathrm{pCi} / \mathrm{L}$ as the performance standard may allow different disposal options. These other options can be evaluated in the design phase. 
Four options are evaluated for disposal of the treated water containing tritium:

- river discharge

- new crib in the $\mathrm{N}$ Area

- new injection well(s) in the $\mathrm{N}$ Area

- new crib in the 200 Area.

Each of these options is described in the following paragraphs.

6.2.1.3.1 River discharge. Treated water from the treatment unit is collected in a tank, providing a surge capacity of 15 minutes prior to discharge to the river. The effluent is continuously monitored for strontium- 90 using an on-line beta counting instrument. The energy of beta particle emissions from strontium-90 is sufficiently different, relative to tritium, that discrimination of strontium-90 is readily achieved. Exceeding pre-set limits for strontium-90 as detected by the monitor would alert the system operator and automatically shut down the system. Once the problem is corrected, the surge tank contents would be reprocessed through the treatment system.

Treated water from the surge tank flows into the river via a buried gravity flow pipeline. The pipeline would be double-wall construction with leak detection systems. It is assumed that the flow would be routed via the existing river outfall (009) or a new outfall. This study assumes use of the existing outfall.

River discharge may require a NPDES permit. Although N Reactor has been operated under an existing NPDES permit since 1980, additional permitting requirements, if any, have not yet been established for river disposal of N Springs treated water. Establishing permitting requirements would require discussions with regulators. In addition, the Tri-Party Agreement Milestone M-17 requires the cessation of liquid effluent discharges by 1995 and may affect the treated water disposal options.

6.2.1.3.2 New Crib in the $100 \mathrm{~N}$ Area. Collection and monitoring of treated water is achieved in the same manner as described for the river discharge option.

Treated water from the surge tank would be pumped to a new crib located in the 100 $\mathrm{N}$ Area. The crib would be a standard Hanford design located so the discharged water would not affect existing contaminant plumes or contaminant sources. Water discharged to the crib would percolate to groundwater and flow into the river. The travel time of the water to the river would not be sufficient to allow depreciable decay of the tritium.

6.2.1.3.3 New injection wells in the $\mathbf{N}$ Area. Collection and monitoring of treated water is achieved in the same manner as described for the river discharge system.

Treated water from the surge tank is pumped to a series of injection wells located in the $100 \mathrm{~N}$ Area. The injection wells would be screened over the entire thickness of the Ringold unit 1 aquifer and would be located so that the discharge water would not affect existing contaminant plumes. Water discharged to injection wells would eventually flow into the river. The travel time of the water to the river would not be sufficient to allow 
appreciable decay of the tritium. In addition, this option may also result in contamination of clean sediments.

If pump and treat is selected as the preferred alternative, other disposal options may be considered in the design phase. An example is a recirculation system proposed through regulatory comment. This system would consist of a series of extraction wells coupled with treatment facilities to remove the strontium-90. The remaining tritiated water would be reinjected upgradient of the extraction wells, presumably near the $1325-\mathrm{N}$ crib. The tritiated water would be contained in an extraction-injection loop which would allow for natural decay of the tritium. Some considerations of this system include the remobilization of contaminants from the sediments underlying the crib and the variability of the extraction rates due to increased groundwater movement from the injection. These issues could be assessed through modeling in the design phase.

6.2.1.3.4 New crib in the 200 Area. Collection and monitoring of treated water is achieved in the same manner as described for the river discharge option.

Treated water from the surge tank is pumped via a cross-country pipeline approximately nine miles to a new crib located in the 200 West Area. This crib is assumed to be in the same vicinity as the one planned for discharging treated wastewater from the 242-A evaporator condensate treatment facility. The crib would be a standard Hanford design. The water would percolate through the soil column and eventually flow to the river through the groundwater system. However, since the travel time to the river is long (model estimates at 105 years), the tritium would decay to well below drinking water limits by the time it reached the river. The estimated travel time of 105 years is about 8.5 half-lives of tritium. At the maximum expected concentration of $80,900 \mathrm{pCi} / \mathrm{L}$, only about two half-lives of decay would actually be required to meet the drinking water MCL for tritium. While the new crib could be located somewhat closer to the river to achieve a travel time of about 50 years, the basis for this study assumes the 200 West Area location.

\subsubsection{Technical Feasibility}

Pump and treat may contribute to final remediation. Technical feasibility of each of the pump and treat pumping options, treatment options, and disposal options are discussed in the following subsections.

6.2.2.1 Pumping Options. Technical feasibility for each of the three pumping options are summarized in Table 6-5.

6.2.2.2 Treatment Options. Both ion exchange and reverse osmosis are considered to be implementable and effective for removing the strontium-90 from $N$ Springs groundwater. However, with either process, the ability to meet the $42 \mathrm{pCi} / \mathrm{L}$ discharge limit cannot be determined without performing treatability studies on samples of actual groundwater. It is likely that both processes could be made to meet the discharge limit, although perhaps at the expense of greater operating severity and cost. The reverse osmosis system is much more complex than the ion exchange system because of the need for chemical pretreatment, 
secondary volume reduction by evaporation, and waste solidification. Table 6-6 summarizes the evaluation against the technical feasibility criteria.

6.2.2.3 Treated Water Disposal Options. The evaluation of technical feasibility of all four treated water disposal options is summarized in Table 6-7.

\subsubsection{Cost Considerations}

Cost estimates for all of the options evaluated in this alternative are summarized in the Tables 6-8 through 6-14. Cost estimate assumptions, sources, and details are documented in Appendix A. All present worth values are based on a discount factor of $10 \%$ and a project life of 10 years.

6.2.3.1 Pumping Options. Costs for the extraction system associated with the pump and treat alternative are given in Table 6-8.

6.2.3.2 Treatment Options. Costs for the treatment system options associated with the pump and treat alternative are given in Tables 6-9 and 6-10.

6.2.3.2.1 Uncertainties. Cost estimates for both the ion exchange and reverse osmosis systems were based on vendor quotations. The ion exchange costs are based on knowledge gained in pilot testing at ORNL. Uncertainty exists for ion exchange in the consumption of media and associated waste generation rate.

Both capital and operating costs for the reverse osmosis system are more uncertain than for ion exchange, especially the operating costs. The vendor operating cost quotes span a wide range. One vendor quoted the total system O\&M costs at 3-5 cents/gallon for a system which uses an evaporator and vacuum drier. Based on the high value, the annual O\&M cost would be nearly $\$ 8$ million for the five-well system. This is almost an order of magnitude higher than the costs developed by different vendors. The discrepancy is not resolved and is indicative of substantial cost uncertainty for the reverse osmosis system at this conceptual level of design.

Disposal costs represent a significant fraction of the costs for the ion exchange treatment system. Disposal costs are generated based on current circumstances at Hanford, e.g., disposal to existing facilities. However, the Environmental Restoration Disposal Facility (ERDF) may allow less costly disposal of the treatment residues. The ERDF schedule lags the $\mathrm{N}$ Springs ERA schedule, but storage of wastes with disposal to ERDF in the future may prove less costly than the proposed disposal to existing facilities. However, the data to confirm this are currently unavailable. The progress of the ERDF and the development of disposal costs should be reevaluated in the design of the pump and treat system to better define disposal costs.

6.2.3.3 Treated Water Disposal Options. Costs for the treated water disposal options associated with the pump and treat alternative are given in Tables 6-11 through 6-14. 


\subsubsection{Institutional Considerations}

Evaluation of institutional considerations for the pumping, treatment, and disposal options are discussed in the subsections below.

6.2.4.1 Pumping Options. The evaluation of institutional considerations for the two pumping options is summarized in Table 6-15.

6.2.4.2 Treatment Options. The evaluation of institutional considerations for the two treatment options is summarized in Table 6-16.

6.2.4.3 Disposal Options. The evaluation of institutional considerations for all four treated water disposal options is summarized in Table 6-17.

\subsubsection{Environmental Impacts}

Environmental impacts for the pumping, treatment, and treated water disposal options are discussed in the subsection below.

6.2.5.1 Pumping Options. The evaluation of environmental impacts for the pump and treat pumping options is summarized in Table 6-18.

6.2.5.2 Treatment Options. Neither treatment option is considered to have significant environmental impact. Ion exchange does not produce air emissions; the reverse osmosis system has the potential to release tritium to the air from the evaporator. Secondary waste is produced from both which is solidified, packaged, and buried as low level radioactive waste.

6.2.5.3 Disposal Options. The evaluation of environmental impacts for the pump and treat disposal options is summarized in Table 6-19.

\subsection{ALTERNATIVE 3 - VERTICAL BARRIERS}

Slurry walls were retained as the single process option for consideration in the vertical barrier alternative. Detailed analysis of this alternative is discussed in the subsections below.

\subsubsection{Description}

The slurry wall option works as a barrier to groundwater flow and creates a diversion of groundwater flow upgradient. The slurry wall causes the groundwater flow direction to change from mainly parallel to the location of the wall to more perpendicular. This acts to reduce the groundwater gradient behind the wall, which lowers groundwater flow velocity behind the wall and thus lengthens the travel time for contaminants to reach the river. At the ends of the wall, the gradient will increase and result in higher than normal flow velocities. 
This results in faster contaminant travel times at the wall ends. Uncertainties to this alternative are the extent of the groundwater gradient reduction behind the wall, the effects of the increased flow velocity at the wall ends, and wall length.

The slurry wall option for N Springs was modeled using the PORFLO-3 groundwater flow and transport model. This model is same as discussed in the no action alternative with the barrier wall added to the base case. The modeled barrier is a 2,800-ft $(853-\mathrm{m})$ long wall nearly spanning the width of the strontium- 90 plume at approximately $100 \mathrm{ft}(30 \mathrm{~m})$ inland from the river. The model assumes a slurry wall hydraulic conductivity of $3 \times 10^{-3} \mathrm{ft} / \mathrm{d}$ $\left(10^{-6} \mathrm{~cm} / \mathrm{sec}\right)$ and a retardation coefficient of 43.3. The wall reduces the contaminant flux to the river by redirecting the groundwater flow around the wall. This results in a reduction of the groundwater gradient behind the wall which reduces the groundwater flow velocity. Strontium-90 tends to bind with the soil and, when combined with the decreased gradient and flow velocity, transport of strontium-90 to the river is reduced. The wall does not completely prevent strontium-90 transport to the river, however modeling results indicate that strontium-90 flux to the river is significantly reduced.

To determine the barrier wall effectiveness, two vertical contaminant flux counting sections were established to add all of the groundwater and strontium- 90 flow passing through those sections. The sections were set at the position of the barrier wall $(100 \mathrm{ft}$ $[30 \mathrm{~m}]$ from the river) and at $33 \mathrm{ft}(10 \mathrm{~m})$ from the river. Each plane was the same length as the wall. Strontium-90 flux through these planes is tabulated on Table 6-1. The negative flux values reported for the barrier wall, $100 \mathrm{ft}(30 \mathrm{~m})$ from the river, are the result of strontium-90 adsorption into the wall. While the wall will adsorb some strontium- 90 , the extent of adsorption has not been estimated. Once equilibrium is reached in the wall, in year 10 , a very small positive flux of strontium- 90 occurs. Based on the strontium- 90 flux values at the $33-\mathrm{ft}(10-\mathrm{m})$ flux section position, the slurry wall restricts $71 \%$ of the strontium-90 flux to the river as compared to the no action alternative. The strontium- 90 flux difference between the $100-\mathrm{ft}(30-\mathrm{m})$ and $33-\mathrm{ft}(10-\mathrm{m})$ sections are a result of strontium-90 leaching from the soils between these two sections. This suggests that the closer the wall is to the river the more strontium-90 mass that will be contained.

Results of the modeling for the year 2002 are shown on Figure 6-6. The figure illustrates the water level configuration and contaminant distribution. It should be noted that the contaminant distribution does not completely match the groundwater flow direction because of the large groundwater mound that was present during LWDF operation (this mound has now dissipated). The radial strontium-90 distribution is due to the original liquid waste disposal patterns at the 1301-N LWDF.

Comiparison of Figure 6-6 (Slurry Wall Alternative) and Figure 6-1 (No Action Alternative) for the zone between the wall and the river suggests that no benefit from the wall is realized. This is not supported by the model results for strontium- 90 flux as presented in Table 6-1. Figure 6-6 depicts groundwater concentrations at a particular point in time, while the flux values (Table 6-1) represent the total strontium-90 flowing across the $33 \mathrm{ft}$ summation section line. The key to understanding the performance of the wall is to consider the strontium-90 flux reduction as shown on Table 6-1. Table 6-1 shows a 
reduction of strontium-90 flux to the river with the wall in place to be approximately $8.9 \mathrm{Ci}$, at a measurement section $33 \mathrm{ft}$ from the river.

The strontium-90 concentrations shown on Figure 6-1 and 6-6, between the modeled wall and the river, are the result of contaminants which have sorbed to the soils and are desorbing through the influx of non-contaminated river water. These sediments will continue to release strontium-90 through the expected duration of the ERA. In addition, the concentrations between the wall and the river are suspect. It would be expected with the wall in place that river action would result in a greater degree of aquifer flushing in this zone resulting in decreasing concentrations with time. This discrepancy is due to river stage assumptions made in the model. The model assumes only four river stage changes during a calendar year. This does not account for the high degree of flushing which occurs due to the frequent and rapid river stage changes which occur daily, monthly, and seasonally. This same uncertainty also applies to the flux calculations presented on Table 6-1.

The model and associated flux values also do not account for the strontium-90 that may flow around the ends of the wall. The potential exists that concentrations higher than those estimated by the model may flow around the wall. Additional modeling is required to more fully quantify the flux reduction as a result of the slurry wall.

The wall modeled with PORFLO-3 was retained for detailed analysis, except that the location of the wall is assumed to be $200 \mathrm{ft}(60 \mathrm{~m})$ from the river instead of $100 \mathrm{ft}(30 \mathrm{~m})$. This was done to avoid placing the wall in the 100-year floodplain which would trigger wetlands analysis and to allow for easier construction in the more level terrain at $200 \mathrm{ft}$ $(60 \mathrm{~m})$ back from the river $(100 \mathrm{ft}[30 \mathrm{~m}]$ from the river is on a steep slope). Locating the wall further back should not affect the ability to reduce strontium- 90 flux from the area of the cribs but would result in more contamination (between the wall and the river) being flushed into the river from already contaminated sediments as a result of fluctuating river stages.

Actual wall placement and length would be considered in the design phase through additional modeling. Placement of the wall closer to the river has several advantages including:

- lower depth to the confining layer resulting in lower costs

- $\quad$ reduced risk of drilling difficulties from boulders

- increased production rates during construction

- $\quad$ reduced strontium-90 flux to river by minimizing contaminated soil between the wall and the river.

From a technical and cost point of view, locating the wall closer to the river (in the floodplain) is advantageous but risks administrative delays in assessing wetlands impacts. The approximate location of the wall for this proposal is shown in Figure 6-7. At its base, the wall would be keyed approximately $3 \mathrm{ft}(1 \mathrm{~m})$ into the underlying Ringold 
paleosol/overbank deposit as shown in Figure 6-8. The wall would be designed to provide a permeability of $10^{-7} \mathrm{~cm} / \mathrm{sec}$ which would severely restrict the movement of contaminant-laden groundwater through the wall. At the proposed location, the total depth from ground surface is estimated to average about $104 \mathrm{ft}(32 \mathrm{~m})$. Placement of the wall in the floodplain would reduce the cost of the wall and its depth to about $50 \mathrm{ft}(15 \mathrm{~m})$.

Two types of construction are considered for installation of a slurry wall at $\mathrm{N}$ Springs, conventional excavation and deep soil mixing. Each type of installation is discussed in the following paragraphs.

6.3.1.1 Excavated Slurry Wall. Conventional slurry wall installation involves the excavation of a trench to a confining layer using a thickened bentonite slurry for excavation support. The trench is sequentially backfilled with a mixture of excavated soils and bentonite or a combination of soil, bentonite, and cement in the case of a plastic concrete wall.

Soil is excavated using a backhoe or an excavator, such as a clamshell or dragline, depending upon the depth required. The $\mathrm{N}$ Springs slurry wall may require the latter because the total depth of the wall at $200 \mathrm{ft}(60 \mathrm{~m})$ from the river is beyond the maximum $70-\mathrm{ft}(21-\mathrm{m})$ reach of backhoes. Backhoes could be used if the wall is placed approximately $50 \mathrm{ft}(15 \mathrm{~m})$ from the river.

As excavated soil is removed from the trench, it is placed on the adjacent ground surface. Bentonite is added to these backfill soils in both dry form and as slurry for moisture conditioning; the bentonite and soils are mixed by plowing with a bulldozer or in a pugmill. Upon completion of mixing, backfill material is pushed into the trench displacing the bentonite slurry mixture and forming a contiguous mass of low permeability wall. Excess soil is generated that may require disposal; approximately $33 \%$ of the total excavated volume for a soil-bentonite wall and up to $60 \%$ for a soil-bentonite-cement wall is excess soil (Spooner et al. 1985). To minimize the volume of contaminated soil produced, materials could be segregated so that the uncontaminated vadose zone soil would make up most of the soil not returned to the trench.

To make a suitable slurry, the fines content of the soil must be in the range of $10 \%$ to $20 \%$. Hanford formation and Ringold Formation soils are lower in fines than required; therefore, some import of fine soil materials or an increase in the amount of bentonite in the slurry mixture is needed to construct the wall. This will likely increase the volume of excess soil requiring disposal. Contaminated soil will have to be disposed as a low level radioactive waste in accordance with DOE Order 5820.2A. In addition, saturated soils excavated from below the water table will require dewatering; the contaminated water fraction will also require suitable disposal.

6.3.1.2 Deep Soil Mixing. Deep soil mixing is a relatively new technique and is available commercially for construction of vertical barriers with properties similar to slurry walls. The equipment used for deep soil mixing consists of a kelly bar and a specially designed large diameter (e.g., 5 to $8 \mathrm{ft}[1.5$ to $2.4 \mathrm{~m}]$ ) auger containing injection nozzles. The assembly is mounted on a crane and is initially driven into the soil mechanically to the depth required. The tool is then withdrawn partially (to approximately half the depth of the wall), 
slurry material injection is initiated as the auger is again driven downward, and slurry injection continues through withdrawal of the auger. The auger mixes the slurry with the soil as it is driven downward and pulled upward. This method of operation ensures thorough mixing of the soil with slurry materials, such as bentonite or combinations of bentonite and cement.

The slurry wall is completed by auguring and mixing a series of overlapping holes. For the $\mathrm{N}$ Springs application, the completed wall would be 3 to $5 \mathrm{ft}(1$ to $1.5 \mathrm{~m})$ thick. A tool which measures $5 \mathrm{ft}(1.5 \mathrm{~m})$ in diameter is specified for the purposes of costing the $\mathrm{N}$ Springs application. According to a vendor, tools of this diameter are capable of operation in Hanford's rocky soils and should meet the minimum requirement of $10^{-6} \mathrm{~cm} / \mathrm{sec}$ permeability. While Hanford soils are rocky, they are also unconsolidated, which is an advantage to the auguring approach. Also, according to the vendor, the probability of achieving a permeability of $10^{-7} \mathrm{~cm} / \mathrm{sec}$ is excellent, because a slurry mix with a high percentage of bentonite and imported fines may be designed to fill the interstitial pores, even in coarse, gravelly soils. The mix would require testing however.

The chief advantage to deep soil mixing is that it does not require removal of contaminated soil, thereby eliminating contaminated soil or water disposal problems. Construction costs are comparable to conventional excavation, but potentially much lower when soil and water disposal costs are taken into account. For this reason, further analysis, including cost analysis, will be conducted under the assumption that deep soil mixing will be used for constructing a slurry wall at $\mathrm{N}$ Springs.

\subsubsection{Technical Feasibility}

Deep soil mixing appears to be a preferred slurry wall construction method for Hanford application because it minimizes contaminated soil removal and disposal. Field trials prior to actual installation may be required to demonstrate a $10^{6} \mathrm{~cm} / \mathrm{sec}$ permeability. In addition, full-scale field testing could be done to demonstrate the viability of deep soil mixing in Hanford soils. Table 6-20 presents a technical feasibility evaluation of a slurry wall installed by deep soil mixing. The slurry wall may contribute to final remediation; however, if removal of the wall becomes an issue in the future, the technical feasibility and costs will be evaluated at that time.

\subsubsection{Cost Considerations}

Cost estimates for all of the options evaluated in this alternative are summarized in Table 6-21. Cost estimate assumptions, sources and details are documented in Appendix A. All present worth vaiues are based on a discount factor of $10 \%$ and a project life of 10 years. 


\subsubsection{Institutional Considerations}

The evaluation of institutional considerations for the slurry wall option is summarized in Table 6-22.

\subsubsection{Environmental Impacts}

The environmental impacts for the slurry wall option are summarized in Table 6-23.

\subsection{ALTERNATIVE 4 - HYDRAULIC CONTROL}

Only one process option was considered for hydraulic control: extraction wells located upgradient from the contaminated groundwater plume. The evaluation of this option is documented in the subsections below.

\subsubsection{Description}

The upgradient hydraulic control option is analyzed to determine its relative effectiveness in reducing contaminant flux to the river by reducing the flow of water from the contaminated portion of the aquifer. This can be accomplished by reducing the hydraulic gradient.

Upgradient hydraulic control is implemented by placing a series of pumping wells upgradient from the contaminant sources to capture the water flowing into the area. A properly designed pumping system results in lowering of the water table at the pumping wells. The wells are placed sufficiently upgradient so that the pumped water is uncontaminated and, therefore, secondary water treatment would not be required. There is, however, a potential to induce groundwater flow from the area of contamination and increase the area of contamination beyond the current upgradient boundary.

To assess the efficiency of the hydraulic control alternative, the two-dimensional numerical groundwater flow model FLOWPATH (Franz and Guiguer 1991) was used. FLOWPATH assumes two-dimensional, steady-state flow with saturated porous media. The model can be used in heterogeneous anisotropic media. The application of the model for $\mathbf{N}$ Springs assumes that the unconfined aquifer system is homogeneous and isotropic.

The model size was set to $5,900 \mathrm{ft}$ by $5,900 \mathrm{ft}(1,800 \mathrm{~m}$ by $1,800 \mathrm{~m})$. Model bou" " " tries were established as constant head nodes along the left, bottom, and right boundaries. Head values were calculated using an initial head value of $392 \mathrm{ft}(119.5 \mathrm{~m})$ in the bottom left corner of the modeled area and a predisposal water table gradient of $0.00095 \mathrm{~m} / \mathrm{m}$ (Connelly et al. 1991), trending southwest to northeast across the model. The river boundary was set as surface water boundary nodes. In the FLOWPATH model, a surface water body node allows the water to set a water surface elevation, bottom elevation, and a streambed leakage factor. For this model, the river stage elevation was set at $385 \mathrm{ft}$ 
$(117.5 \mathrm{~m})$ at the upstream node at the left of the model. A river gradient of $0.000256 \mathrm{~m} / \mathrm{m}$ (Connelly et al. 1991) was applied to determine river elevations downstream. A river depth of $30 \mathrm{ft}(10 \mathrm{~m})$ and a leakage factor of 6.7 was used to further define the nodes. Aquifer properties used in the model are the same as those used by Connelly et al. (1991) to model the no action alternative.

The goal of upgradient hydraulic control is to reduce the groundwater flow to the river by at least $50 \%$ without causing spread of strontium- 90 contamination upgradient toward the pumping wells. Several different upgradient well placement and pumping rate scenarios were modeled to determine the optimum well placement within the constraints of the model. The resulting well configuration and pumping rates are shown on Figure 6-9. The configuration consists of 11 pumping wells set in a radial pattern upgradient from the $1325-\mathrm{N}$ facility. Pumping rates vary from 75 to $150 \mathrm{gal} / \mathrm{min}$. The total flow of all wells is $1,100 \mathrm{gal} / \mathrm{min}$. All pumped water is monitored and discharged directly to the river through a new outfall.

This scenario resulted in a reduction in groundwater flow to the river of approximately $50 \%$ within the $1,000 \mathrm{pCi} / \mathrm{L}$ concentration contour for the 1990 concentration data and $45 \%$ of the groundwater flow within the $42 \mathrm{pCi} / \mathrm{L}$ contour. The hydraulic gradients are altered gradually before reaching steady-state. Steady-staie conditions would probably be reached in a matter of months; however, more comprehensive modeling is required to precisely determine the time to reach steady-state conditions.

As discussed for the fump and treat options, because the model assumes that the unconfined aquifer is both homogeneous and isotropic, there is some uncertainty in the validity of the final results. The aquifer may have zones of higher or lower conductivity that may have a directional component. This could serve as preferred pathways for groundwater and contaminant flow and could affect the capture zone of individual pumping wells. In the actual system operation, these effects could be mitigated to some extent by varying the pumping rates from individual wells to balance out the hydrogeologic uncertainties.

\subsubsection{Technical Feasibility}

Hydraulic control may contribute to final remediation. Table 6-24 presents a technical feasibility evaluation of upgradient hydraulic control.

\subsubsection{Cost Considerations}

Cost estimates for all of the options evaluated in this alternative are summarized in Table 6-25. Cost estimate assumptions, sources, and details are documented in Appendix A. All present worth values are based on a discount factor of $10 \%$ and a project life of 10 years. 
DOE\RL-93-23, Rev. 0

\subsubsection{Institutional Considerations}

The evaluation of institutional considerations for the hydraulic control option is summarized in Table 6-26.

\subsubsection{Environmental Impacts}

The environmental impacts for the hydraulic control are summarized in Table 6-27. 
Figure 6-1 Groundwater Levels and Strontium-90 Concentration Estimates Based on Groundwater Modeling for the Year 2002 - No Action Alternative


H9303009.2 


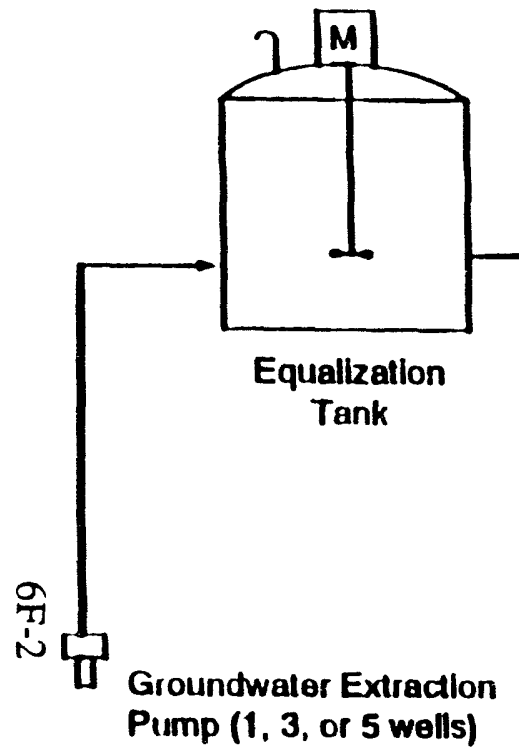

\section{STREAM IDENTIFICATION}

(1) Process Feed

(2) Treated Groundwater

(3) Crib Disposallnjection Wells

(1) River Disposal

(5) Recycle (if needed)

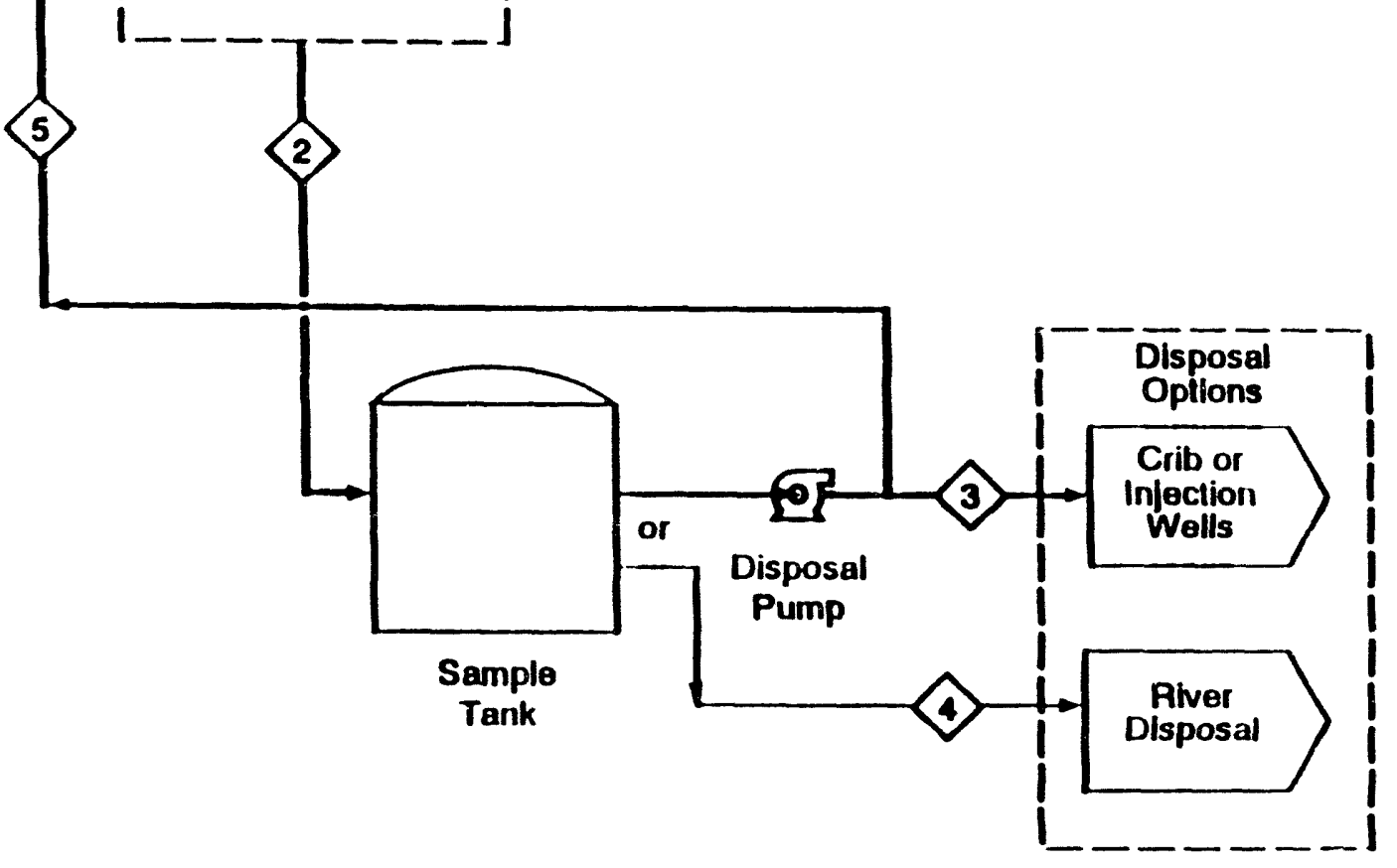

\section{Trealmonl:}

(See Fig. 6-5)

Revereo Oemosls

(See Flo. 6-6) 
Figure 6-3 Groundwater Levels and Strontium-90 Concentration Estimates Based on Groundwater Modeling for the Year 2002 - Five-Well Pump and Treat System
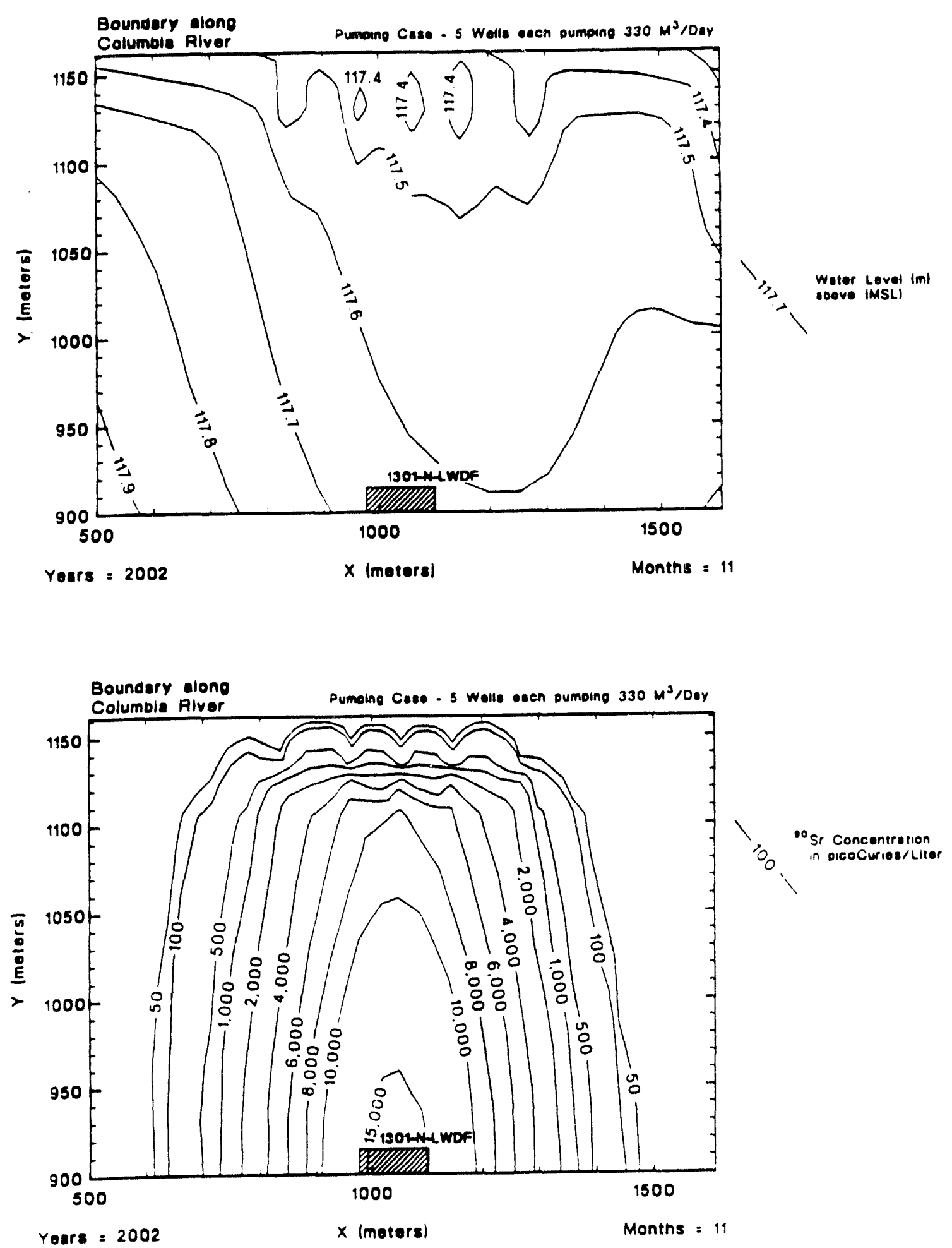


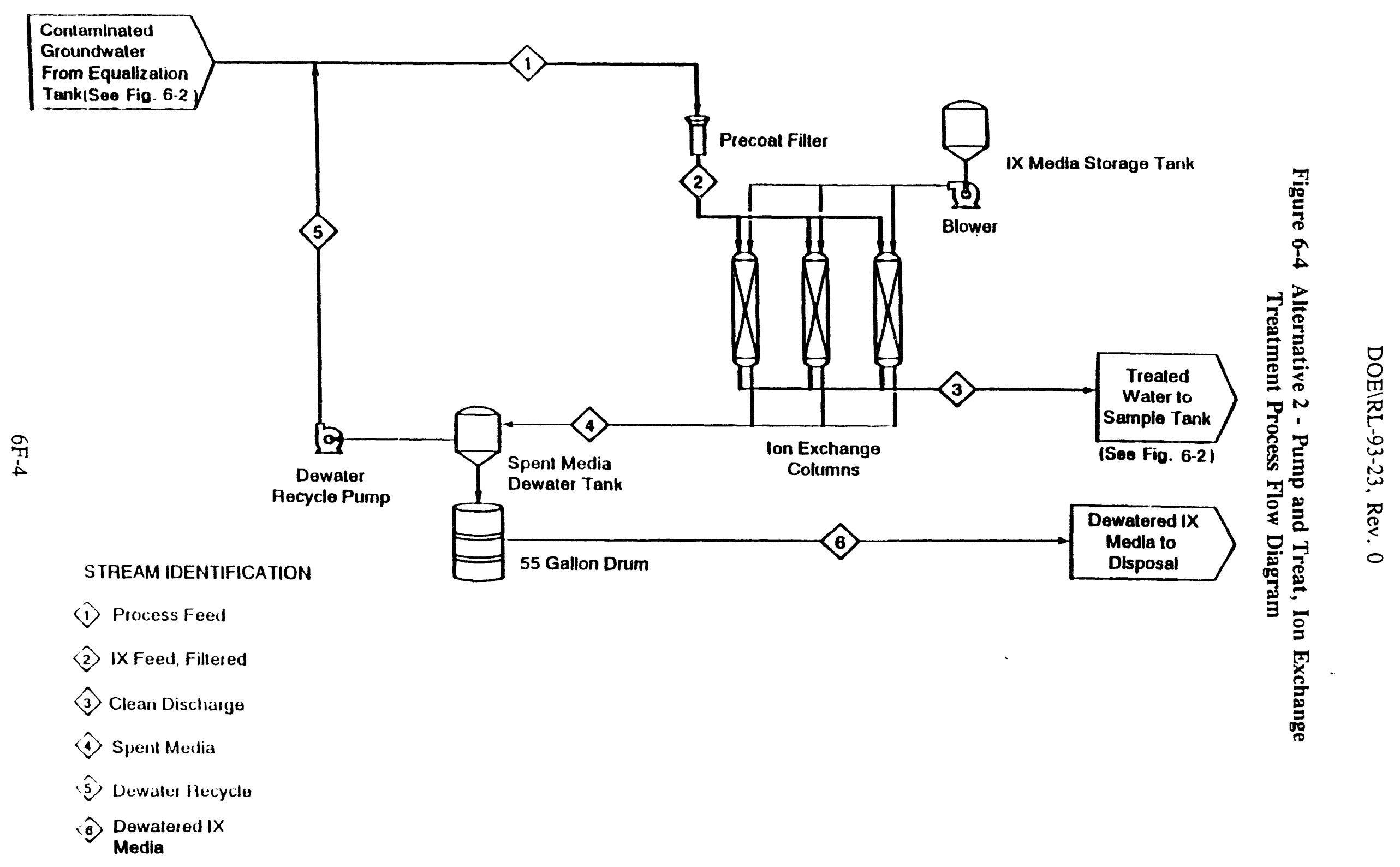




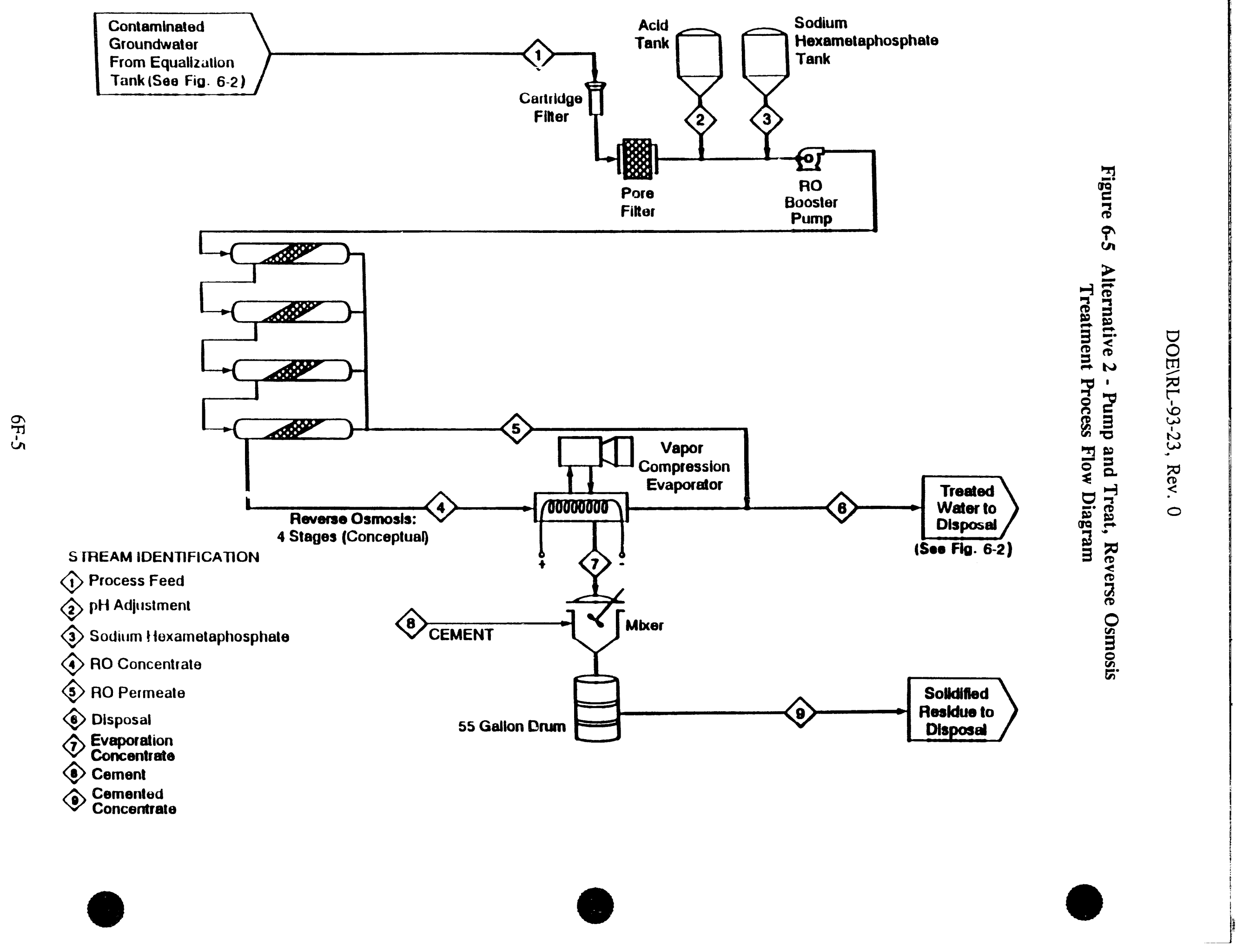


Figure 6-6 Groundwater Levels and Strontium-90 Concentration Estimates Based on Groundwater Modeling for the Year 2002 - Slurry Wall Alternative

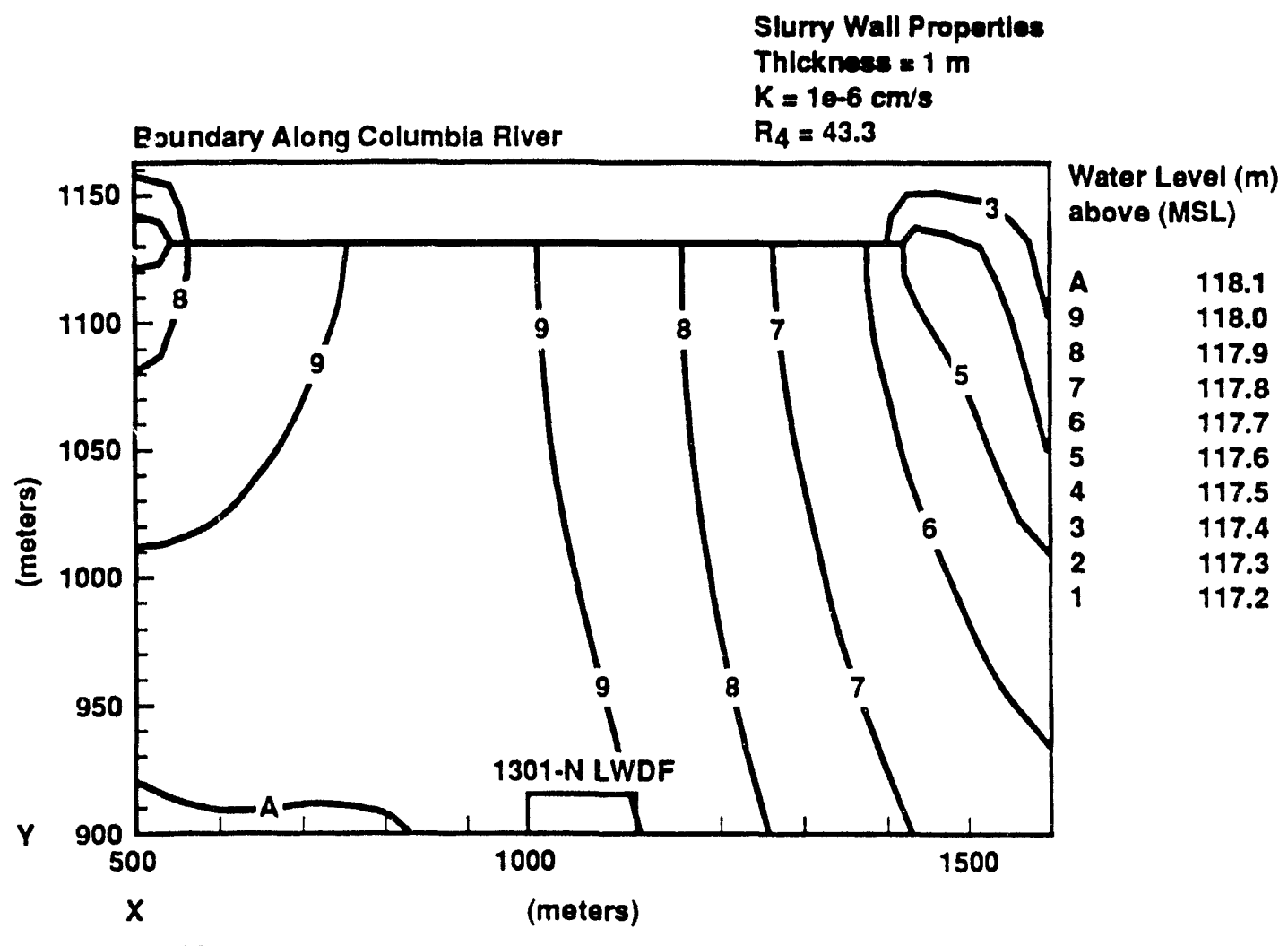

Year $=2002$

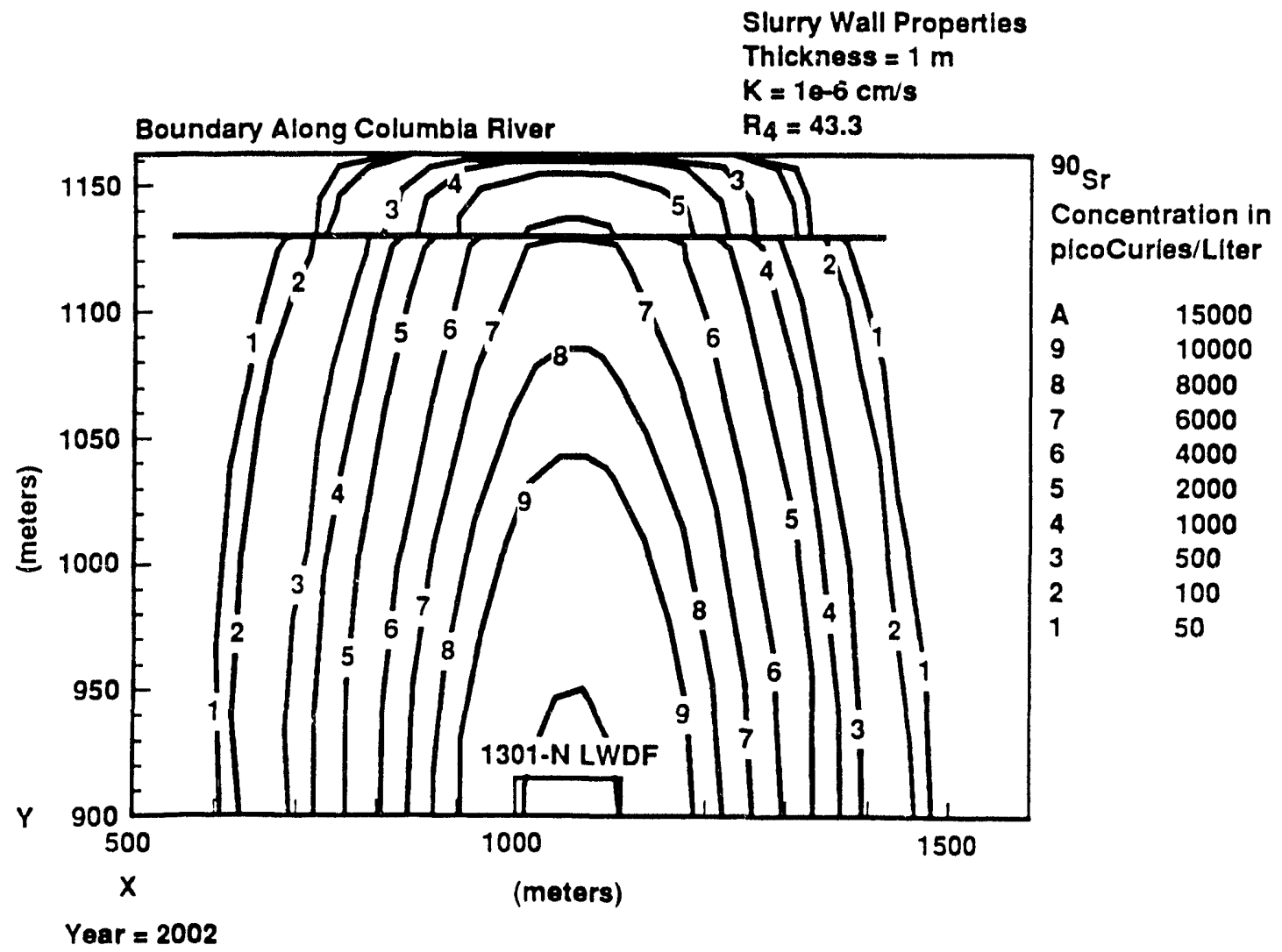




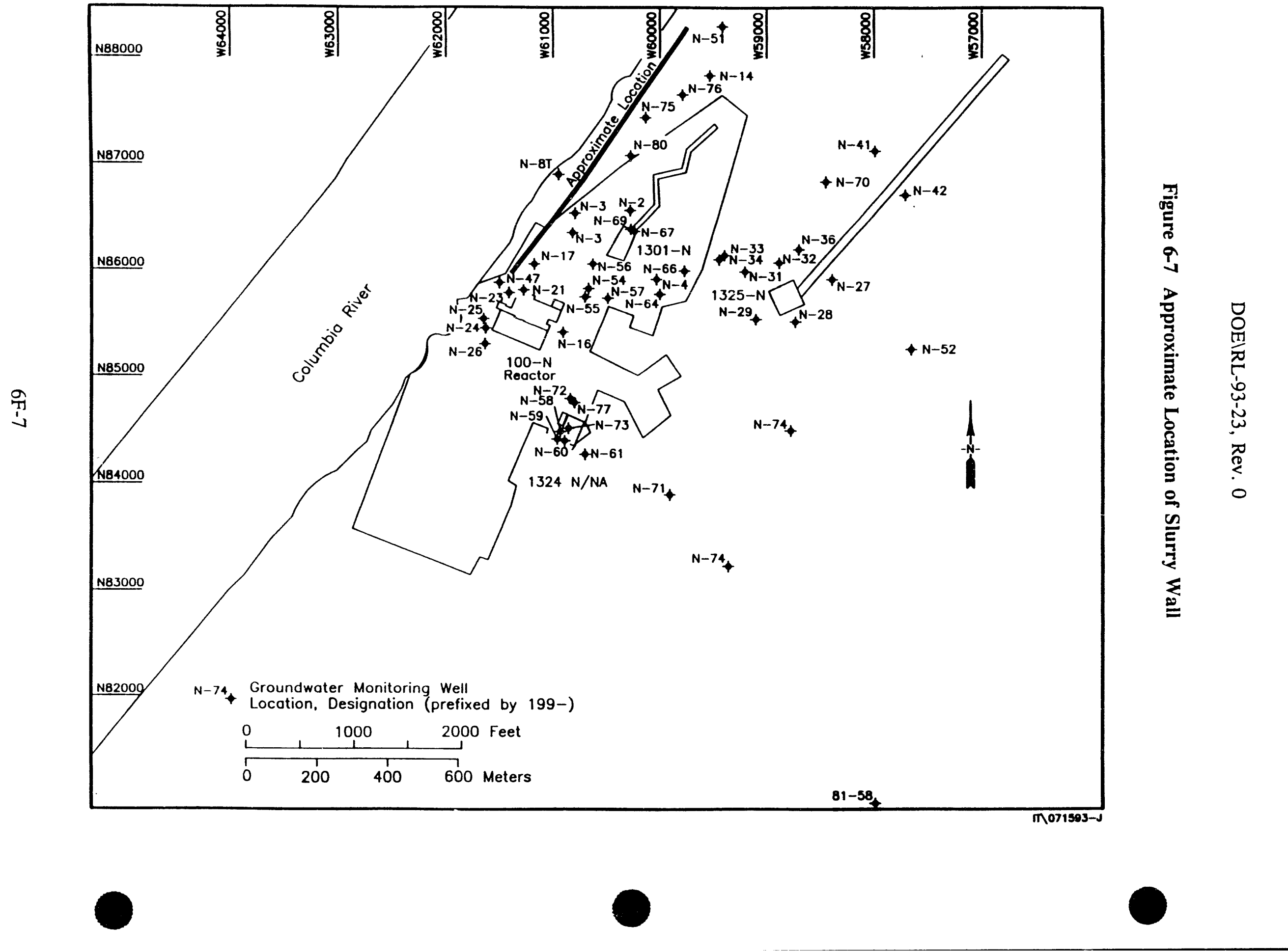



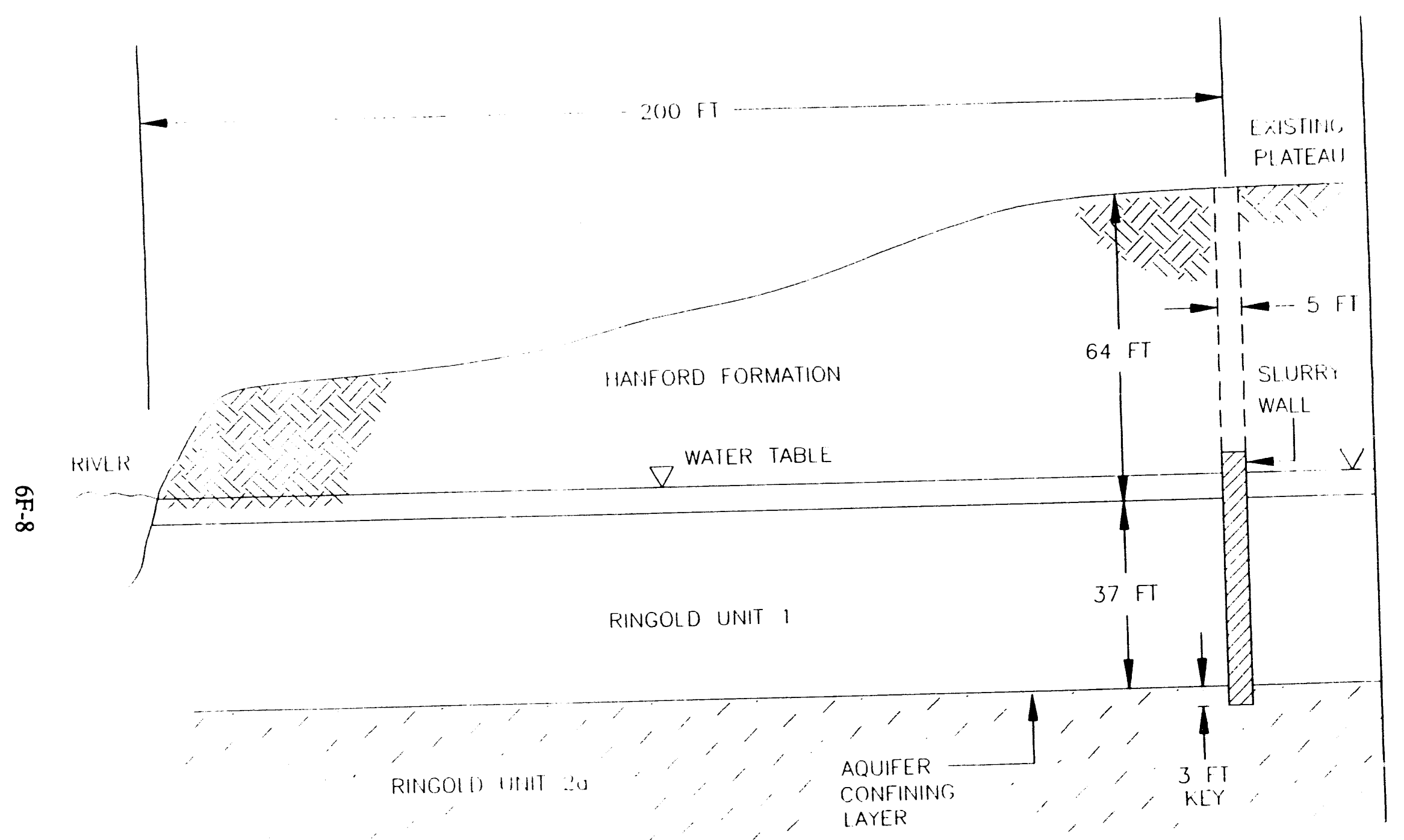

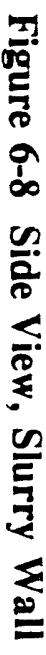

RINGOIO IIIHT :

CONFININC

LAYER

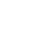




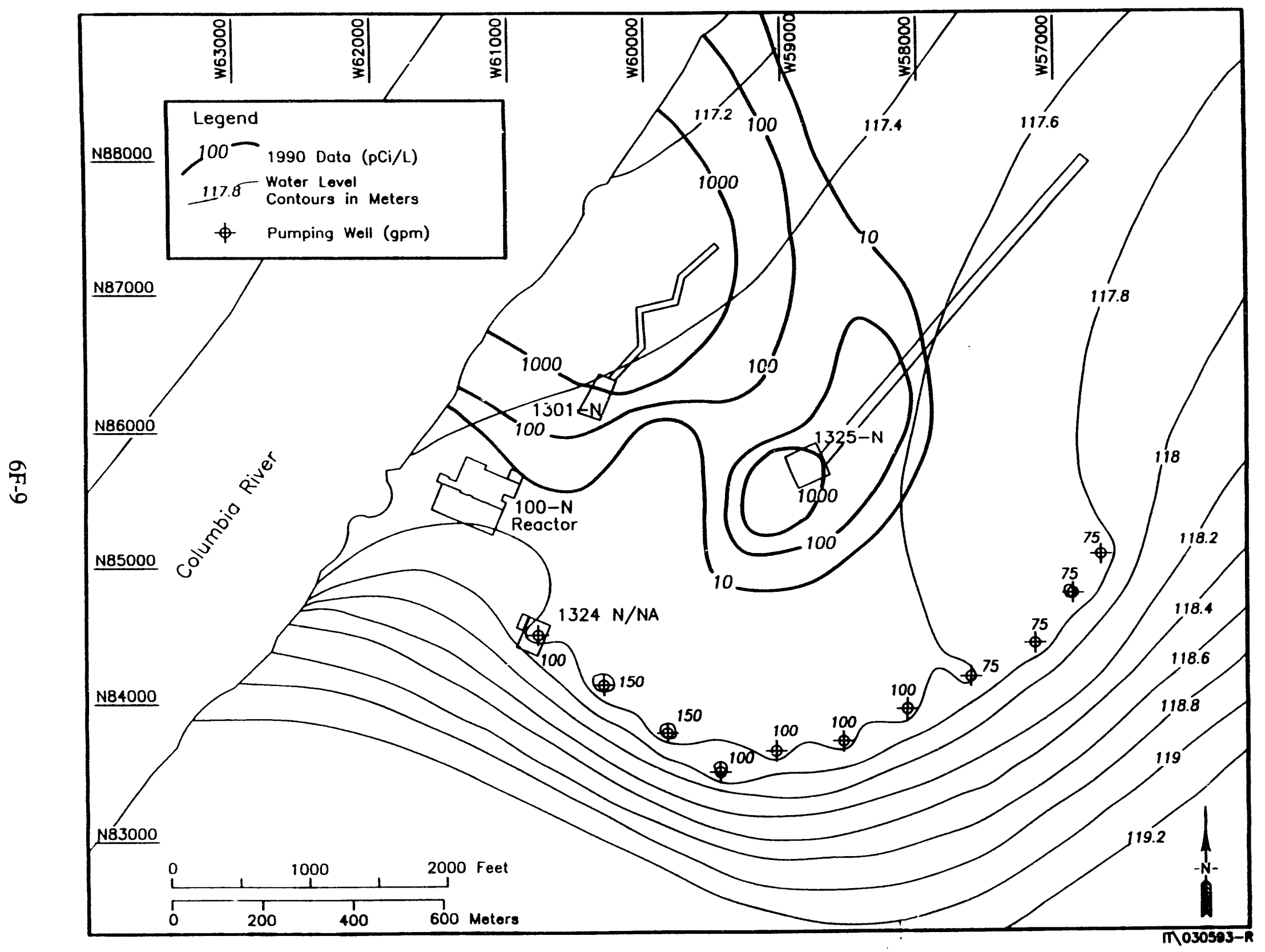

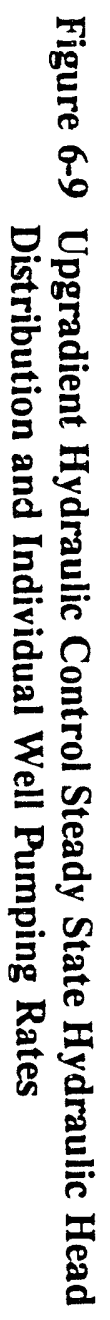


DOE \RL-93-23, Rev. 0

Table 6-1 Annual Strontium-90 Flux (Ci/yr) Through Two Summation Sections Placed 33 and $100 \mathrm{ft}$ from the River as Predicted by Modeling

33 ft From River ${ }^{2}$

\begin{tabular}{||c|c|c|c|c|}
\hline Year & No Action & 3 Wells & 5 Wells & Slurry Wall \\
\hline \hline 1991 & 1.5 & 0.42 & $-0.347^{1}$ & 0.37 \\
1992 & 1.5 & 0.64 & 0.080 & 0.39 \\
1993 & 1.3 & 0.54 & 0.098 & 0.39 \\
1994 & 1.2 & 0.46 & 0.088 & 0.38 \\
1995 & 1.1 & 0.39 & 0.075 & 0.37 \\
1996 & 1.0 & 0.34 & 0.063 & 0.35 \\
1997 & 1.0 & 0.30 & 0.053 & 0.33 \\
1998 & 0.9 & 0.27 & 0.044 & 0.31 \\
1999 & 0.9 & 0.24 & 0.037 & 0.29 \\
2000 & 0.8 & 0.21 & 0.032 & 0.28 \\
2001 & 0.8 & 0.19 & 0.027 & 0.25 \\
2002 & 0.8 & 0.17 & 0.023 & 0.24 \\
\hline \hline
\end{tabular}

100 Ft From River ${ }^{2}$

\begin{tabular}{|c|c|c|c|c|}
\hline Year & No Action & 3 Wells & 5 Wells & Slurry Wall \\
\hline \hline 1991 & 1.0 & -0.46 & -1.86 & $-2.99 \mathrm{e}-3$ \\
1992 & 1.2 & -0.22 & -1.46 & $-5.38 \mathrm{e}-3$ \\
1993 & 1.1 & -0.26 & -1.22 & $-5.73 \mathrm{e}-3$ \\
1994 & 0.9 & -0.26 & -0.97 & $-5.06 \mathrm{e}-3$ \\
1995 & 0.9 & -0.23 & -0.75 & $-1.06 \mathrm{e}-3$ \\
1996 & 0.8 & -0.19 & -0.57 & $-3.02 \mathrm{e}-3$ \\
1997 & 0.8 & -0.16 & -0.43 & $-2.06 \mathrm{e}-3$ \\
1998 & 0.8 & -0.11 & -0.33 & $-1.21 \mathrm{e}-3$ \\
1999 & 0.7 & -0.08 & -0.25 & $-4.70 \mathrm{e}-4$ \\
2000 & 0.7 & -0.05 & -0.19 & $1.50 \mathrm{e}-4$ \\
2001 & 0.6 & -0.03 & -0.14 & $7.00 \mathrm{e}-4$ \\
2002 & 0.7 & -0.01 & -0.11 & $1.15 \mathrm{e}-3$ \\
\hline \hline TOTAL & 10.2 & -2.06 & -8.28 & $-2.50 \mathrm{e}-2$ \\
\hline
\end{tabular}

Positive values indicate a net $\mathrm{Sr}-90$ mass movement toward the river and negative values indicate net mass movement toward the wells or slurry wall.

Both summation sections are for wells or the slurry wall located $100 \mathrm{ft}$ from the river. 
Table 6-2 Technical Feasibility Evaluation for No Action Alternative

\begin{tabular}{|c|c|}
\hline Criteria & Evaluation \\
\hline Ability to comply with ARAR & $\begin{array}{l}\text { Does not comply with chemical-specific } \\
\text { ARAR such as the drinking water MCL }\end{array}$ \\
\hline $\begin{array}{l}\text { Effectiveness in reducing toxicity, mobility, } \\
\text { or volume of contamination }\end{array}$ & $\begin{array}{l}\text { None is attained except that achieved } \\
\text { through natural attenuation, primarily } \\
\text { through radioactive decay }\end{array}$ \\
\hline $\begin{array}{l}\text { Demonstrated performance and reliability } \\
\text { under similar conditions }\end{array}$ & No action - not applicable \\
\hline Useful life & No action - not applicable \\
\hline Constructability & No action - not applicable \\
\hline Operation and maintenance requirements & $\begin{array}{l}\text { No incremental requirements beyond } \\
\text { existing controls and monitoring }\end{array}$ \\
\hline Environmental effects on performance & None \\
\hline Sensitivities and uncertainties & $\begin{array}{l}\text { Some uncertainties exist in the data with } \\
\text { regard to plume concentration profiles; } \\
\text { some uncertainty associated with modeling } \\
\text { parameters and modeling predictions, } \\
\text { however these uncertainties do not affect } \\
\text { this alternative because no actions are taken }\end{array}$ \\
\hline
\end{tabular}

ARAR - applicable or relevant and appropriate requirements MCL - maximum contaminant level 
DOE $\backslash$ RL-93-23, Rev. 0

Table 6-3 Institutional Considerations Evaluation for No Action Alternative

\begin{tabular}{||l|l||}
\hline \multicolumn{1}{|c|}{ Criteria } & \multicolumn{1}{c|}{ Evaluation } \\
\hline \hline Ability to achieve removal action objectives & Does not achieve objectives \\
\hline Regulatory concerns about the technology & $\begin{array}{l}\text { Likely unfavorable because ERA objectives } \\
\text { are not achieved }\end{array}$ \\
\hline Permitting requirements & None \\
\hline Safety & No action - not applicable \\
\hline Timeliness & $\begin{array}{l}\text { Contamination reduction achievable by } \\
\text { natural attenuation only in the long term }\end{array}$ \\
\hline
\end{tabular}

ERA - expedited response action 
DOE\RL-93-23, Rev. 0

Table 6-4 Environmtucal unpacts Evaluation of No Action Alternative

\begin{tabular}{||l|l||}
\hline \multicolumn{1}{|c|}{ Criteria } & \multicolumn{1}{|c|}{ Evaluation } \\
\hline $\begin{array}{c}\text { Environmental impacts on: } \\
\text { Topography and surface } \\
\text { drainage }\end{array}$ & No impact \\
\hline Geology & No impact \\
\hline Soils & Riverbank sediments will continue to be contaminated \\
\hline $\begin{array}{l}\text { Surface water hydrology } \\
\text { and quality }\end{array}$ & $\begin{array}{l}\text { Flow of contamination into the river will continue to } \\
\text { impact the near-shore surface water quality }\end{array}$ \\
\hline $\begin{array}{l}\text { Groundwater hydrology } \\
\text { and quality }\end{array}$ & $\begin{array}{l}\text { Contamination will continue to impact local } \\
\text { groundwater quality }\end{array}$ \\
\hline $\begin{array}{l}\text { Meteorology and air } \\
\text { quality }\end{array}$ & No impact \\
\hline Biological resources & $\begin{array}{l}\text { Contamination from springs will continue to } \\
\text { potentially impact riparian and aquatic biota }\end{array}$ \\
\hline Cultural resources & No impact \\
\hline Land and water use & $\begin{array}{l}\text { Local groundwater and land use will continue to } \\
\text { require restriction }\end{array}$ \\
\hline Visual resources & No impact \\
\hline
\end{tabular}


DOE \RL-93-23, Rev. 0

Table 6-5 Technical Feasibility Evaluation for Groundwater Extraction Options

\begin{tabular}{|c|c|c|}
\hline \multirow{2}{*}{ Criteria } & \multicolumn{2}{|c|}{ Evaluation } \\
\hline & Five-Well System & Three-Well System \\
\hline $\begin{array}{l}\text { Ability to comply } \\
\text { with ARAR }\end{array}$ & $\begin{array}{l}\text { Removes contaminated water } \\
\text { but does not meet chemical- } \\
\text { specific ARAR }\end{array}$ & $\begin{array}{l}\text { Same as five-well system; less } \\
\text { contaminated water is removed }\end{array}$ \\
\hline $\begin{array}{l}\text { Effectiveness in } \\
\text { reducing toxicity, } \\
\text { mobility, or volume } \\
\text { of contamination }\end{array}$ & $\begin{array}{l}\text { Contaminated water flow to the } \\
\text { river is greatly restricted } \\
\text { (potentially } 100 \% \text { of the } \\
>1,000 \mathrm{pCi} / \mathrm{L} \text { plume) }\end{array}$ & $\begin{array}{l}\text { Contaminated water flow is } \\
\text { restricted to a lesser extent } \\
\text { than the five-well system }\end{array}$ \\
\hline Useful life & Meets requirements & Meets requirements \\
\hline Constructability & $\begin{array}{l}\text { Pumping wells are readily } \\
\text { constructable }\end{array}$ & $\begin{array}{l}\text { Same as five-well system; } \\
\text { constructability somewhat } \\
\text { easier because of fewer wells }\end{array}$ \\
\hline $\begin{array}{l}\text { Operation and } \\
\text { maintenance (O\&M) } \\
\text { requirements }\end{array}$ & $\begin{array}{l}\text { Operation is not complex; } \\
\text { moderate maintenance required } \\
\text { for pumps }\end{array}$ & $\begin{array}{l}\text { Same as five-well system; } \\
\text { lower O\&M due to less wells }\end{array}$ \\
\hline $\begin{array}{l}\text { Environmental } \\
\text { effects on } \\
\text { performance }\end{array}$ & None anticipated & None anticipated \\
\hline $\begin{array}{l}\text { Sensitivities and } \\
\text { uncertainties }\end{array}$ & $\begin{array}{l}\text { Uncertainties in plume } \\
\text { concentration distribution and } \\
\text { hydrologic properties; this } \\
\text { option is less vulnerable to } \\
\text { uncertainties since it uses five } \\
\text { pumping wells }\end{array}$ & $\begin{array}{l}\text { Same uncertainties as five-well } \\
\text { system, but more vulnerable to } \\
\text { uncertainties since fewer wells } \\
\text { are used }\end{array}$ \\
\hline
\end{tabular}

ARAR - applicable or relevant and appropriate requirements 
DOE $\backslash$ RL-93-23, Rev. 0

Table 6-6 Technical Feasibility Evaluation of Groundwater Treatment Options

\begin{tabular}{|c|c|c|}
\hline \multirow{2}{*}{ Criteria } & \multicolumn{2}{|c|}{ Evaluation } \\
\hline & Ion Exchange & Reverse Osmosis \\
\hline $\begin{array}{l}\text { Ability to comply with } \\
\text { ARAR }\end{array}$ & $\begin{array}{l}\text { Tritium not removed; ability to } \\
\text { meet strontium- } 90 \mathrm{MCL} \text { is } \\
\text { uncertain; treatability studies } \\
\text { are needed }\end{array}$ & Same as ion exchange \\
\hline $\begin{array}{l}\text { Effectiveness in reducing } \\
\text { toxicity, mobility, or } \\
\text { volume of contamination }\end{array}$ & $\begin{array}{l}\text { Effective in removing } \\
\text { strontium-90 from extracted } \\
\text { groundwater; not effective in } \\
\text { tritium removal }\end{array}$ & Same as ion exchange \\
\hline $\begin{array}{l}\text { Demonstrated } \\
\text { performance and } \\
\text { reliability under similar } \\
\text { conditions }\end{array}$ & $\begin{array}{l}\text { ion exchange has been used } \\
\text { extensively for radioactive } \\
\text { wastewater treatment }\end{array}$ & $\begin{array}{l}\text { Application for radioactive } \\
\text { wastewater is more limited } \\
\text { but has been proven }\end{array}$ \\
\hline Useful life & Meets requiremerts & Meets requirements \\
\hline Constructability & $\begin{array}{l}\text { Commercially available systems } \\
\text { are designed and constructed as } \\
\text { package units by multiple } \\
\text { vendors }\end{array}$ & $\begin{array}{l}\text { Commercially available but } \\
\text { not to the same extent as } \\
\text { ion exchange }\end{array}$ \\
\hline $\begin{array}{l}\text { Operation and } \\
\text { maintenance } \\
\text { requirements }\end{array}$ & $\begin{array}{l}\text { System is designed to operate } \\
\text { automatically; periodic need for } \\
\text { ion exchange media } \\
\text { replacement and disposal of } \\
\text { spent media }\end{array}$ & $\begin{array}{l}\text { Operation and maintenance } \\
\text { are more complex due to } \\
\text { evaporator and residue } \\
\text { solidification }\end{array}$ \\
\hline $\begin{array}{l}\text { Environmental effects on } \\
\text { performance }\end{array}$ & $\begin{array}{l}\text { System in enclosed building; } \\
\text { none anticipated }\end{array}$ & Same as ion exchange \\
\hline $\begin{array}{l}\text { Sensitivities and } \\
\text { uncertainties }\end{array}$ & $\begin{array}{l}\text { Treatability studies required to } \\
\text { optimize meciia selection, } \\
\text { determine waste generation } \\
\text { rate, and treatment performance }\end{array}$ & $\begin{array}{l}\text { Treatability studies } \\
\text { required to determine } \\
\text { waste generation rate, } \\
\text { membrane life, and } \\
\text { treatment performance }\end{array}$ \\
\hline
\end{tabular}

ARAR - applicable or relevant and appropriate requirements

$M C L$ - maximum contaminant level 
Table 6-7 Technical Feasibility Evaluation of Treated Water

Disposal Options (Page 1 of 2)

\begin{tabular}{|c|c|c|c|c|}
\hline \multirow{2}{*}{ Criteria } & \multicolumn{4}{|c|}{ Evaluation } \\
\hline & $\begin{array}{c}\text { River } \\
\text { Discharge }\end{array}$ & N Area Crib & $\begin{array}{l}\text { N Area } \\
\text { Injection }\end{array}$ & 200 Area Crib \\
\hline $\begin{array}{l}\text { Ability to } \\
\text { comply with } \\
\text { ARAR }\end{array}$ & $\begin{array}{l}\text { Does not meet } \\
\text { tritium } \mathrm{MCL}\end{array}$ & $\begin{array}{l}\text { Does not meet } \\
\text { tritium } \mathrm{MCL}\end{array}$ & $\begin{array}{l}\text { Does not meet } \\
\text { tritium MCL }\end{array}$ & $\begin{array}{l}\text { Meets tritium } \\
\text { MCL }\end{array}$ \\
\hline $\begin{array}{l}\text { Effectiveness in } \\
\text { reducing, } \\
\text { toxicity, } \\
\text { mobility or } \\
\text { volume of } \\
\text { contamination }\end{array}$ & $\begin{array}{l}\text { Effective } \\
\text { except for } \\
\text { tritium }\end{array}$ & $\begin{array}{l}\text { Effective } \\
\text { except for } \\
\text { tritium }\end{array}$ & $\begin{array}{l}\text { Effective } \\
\text { except for } \\
\text { tritium }\end{array}$ & $\begin{array}{l}\text { Effective for all } \\
\text { contaminants }\end{array}$ \\
\hline $\begin{array}{l}\text { Demonstrated } \\
\text { performance } \\
\text { and reliability } \\
\text { under similar } \\
\text { conditions }\end{array}$ & $\begin{array}{l}\text { The discharge } \\
\text { system is } \\
\text { simple and } \\
\text { expected to } \\
\text { perform } \\
\text { reliably }\end{array}$ & $\begin{array}{l}\text { Slightly more } \\
\text { complex than } \\
\text { river discharge } \\
\text { but } \\
\text { performance is } \\
\text { well established } \\
\text { at Hanford }\end{array}$ & $\begin{array}{l}\text { Injection wells } \\
\text { are subject to } \\
\text { plugging and } \\
\text { therefore } \\
\text { reliability is } \\
\text { somewhat less } \\
\text { than other } \\
\text { options }\end{array}$ & $\begin{array}{l}\text { Crib } \\
\text { performance is } \\
\text { reliable; long } \\
\text { pipeline to } 200 \\
\text { Area is more } \\
\text { vulnerable to } \\
\text { leaks and other } \\
\text { operating } \\
\text { problems }\end{array}$ \\
\hline Useful life & $\begin{array}{l}\text { Meets project } \\
\text { goals }\end{array}$ & $\begin{array}{l}\text { Meets project } \\
\text { goals }\end{array}$ & $\begin{array}{l}\text { Meets project } \\
\text { goals }\end{array}$ & $\begin{array}{l}\text { Meets project } \\
\text { goals }\end{array}$ \\
\hline Constructability & $\begin{array}{l}\text { Easily } \\
\text { constructable }\end{array}$ & $\begin{array}{l}\text { Easily } \\
\text { constructable }\end{array}$ & $\begin{array}{l}\text { Easily } \\
\text { constructable }\end{array}$ & $\begin{array}{l}\text { More difficult } \\
\text { constructability } \\
\text { because of long } \\
\text { pipeline }\end{array}$ \\
\hline $\begin{array}{l}\text { Operation and } \\
\text { maintenance } \\
\text { requirements }\end{array}$ & $\begin{array}{l}\text { Very low since } \\
\text { it is a gravity } \\
\text { flow system }\end{array}$ & $\begin{array}{l}\text { Low since } \\
\text { pumping } \\
\text { requirements } \\
\text { are not high }\end{array}$ & $\begin{array}{l}\text { Low since } \\
\text { pumping } \\
\text { requirements } \\
\text { are not high }\end{array}$ & $\begin{array}{l}\text { High cost for } \\
\text { pump operation } \\
\text { and } \\
\text { maintenance of } \\
\text { long pipeline }\end{array}$ \\
\hline $\begin{array}{l}\text { Environmental } \\
\text { effects on } \\
\text { performance }\end{array}$ & $\begin{array}{l}\text { None } \\
\text { anticipated }\end{array}$ & $\begin{array}{l}\text { None } \\
\text { anticipated }\end{array}$ & $\begin{array}{l}\text { None } \\
\text { anticipated }\end{array}$ & $\begin{array}{l}\text { None } \\
\text { anticipated }\end{array}$ \\
\hline
\end{tabular}


DOE $\backslash$ RL-93-23, Rev. 0

Table 6-7 Technical Feasibility Evaluation of Treated Water Disposal Options (Page 2 of 2)

\begin{tabular}{||l|l|l|l|l|}
\hline \multirow{2}{*}{ Criteria } & \multicolumn{4}{|c|}{ Evaluation } \\
\cline { 2 - 5 } & \multicolumn{1}{|c|}{$\begin{array}{c}\text { River } \\
\text { Discharge }\end{array}$} & N Area Crib & \multicolumn{1}{|c|}{$\begin{array}{c}\text { N Area } \\
\text { Injection }\end{array}$} & 200 Area Crib \\
\hline $\begin{array}{l}\text { Sensitivities and } \\
\text { uncertainties }\end{array}$ & $\begin{array}{l}\text { Some } \\
\text { uncertainties } \\
\text { exist in the data } \\
\text { with regard to } \\
\text { tritium plume } \\
\text { concentration } \\
\text { profiles; } \\
\text { discharge levels } \\
\text { will probably } \\
\text { be somewhat } \\
\text { lower than } \\
\text { assumed for } \\
\text { this study }\end{array}$ & $\begin{array}{l}\text { Same as river } \\
\text { discharge } \\
\text { discharge }\end{array}$ & $\begin{array}{l}\text { Same as river } \\
\text { undersized if } \\
\text { flow rates have } \\
\text { to be increased } \\
\text { beyond design } \\
\text { capacity }\end{array}$ \\
\hline
\end{tabular}

ARAR - applicable or relevant and appropriate requirement MCL - maximum contaminant level 
DOE/RL-93-23, Rev. 0

Table 6-8 Cost Evaluation for Groundwater Extraction Options

\begin{tabular}{||l|c|c||}
\hline \multirow{2}{*}{ Cost in Millions of 1993 Dollars } & \multicolumn{2}{|c|}{ Extraction System } \\
\cline { 2 - 3 } & Five-Well System & Three-Well System \\
\hline \hline Capital Cost & 1.53 & 1.01 \\
\hline Annual O\&M Cost & 0.03 & 0.02 \\
\hline Present Worth & 1.77 & 1.17 \\
\hline
\end{tabular}

O\&M - operating and maintenance 
DOE/RL-93-23, Rev. 0

Table 6-9 Cost Evaluation for Ion Exchange System

\begin{tabular}{||l|c|c|}
\hline Cost in Millions of 1993 Dollars & Five-Well System & Three-Well System \\
\hline \hline Capital Cost & 2.97 & 2.11 \\
\hline Annual O\&M Cost & 1.29 & 0.78 \\
\hline Present Worth & 12.94 & 8.14 \\
\hline
\end{tabular}

O\&M - operating and maintenance 
DOE/RL-93-23, Rev. 0

Table 6-10 Cost Evaluation for Reverse Osmosis System

\begin{tabular}{||l|c|c|}
\hline Cost in Millions of $\mathbf{1 9 9 3}$ Dollars & Five-Well System & Three-Well System \\
\hline \hline Capital Cost & 2.26 & 1.58 \\
\hline Annual O\&M Cost & 0.83 & 0.50 \\
\hline Present Worth & 8.70 & 5.45 \\
\hline
\end{tabular}

O\&M - operating and maintenance 
DOE/RL-93-23, Rev. 0

Table 6-11 Cost Evaluation for River Disposal

\begin{tabular}{||l|c|c|}
\hline Cost in Millions of $\mathbf{1 9 9 3}$ Dollars & Five-Well System & Three-Well System \\
\hline \hline Capital Cost & 0.06 & 0.05 \\
\hline Annual O\&M Cost & $<0.01$ & $<0.01$ \\
\hline Present Worth & 0.07 & 0.06 \\
\hline
\end{tabular}

O\&M - operating and maintenance 
DOE/RL-93-23, Rev. 0

Table 6-12 Cost Evaluation for N Area Crib Disposal

\begin{tabular}{|l|c|c|}
\hline Cost in Millions of $\mathbf{1 9 9 3}$ Dollars & Five-Well System & Three-Well System \\
\hline \hline Capital Cost & 2.85 & 2.05 \\
\hline Annual O\&M Cost & $<0.01$ & $<0.01$ \\
\hline Present Worth & 2.92 & 2.09 \\
\hline
\end{tabular}

O\&M - operating and maintenance 
DOE/RL-93-23, Rev. 0

Table 6-13 Cost Evaluation for $\mathbf{N}$ Area Reinjection

\begin{tabular}{||l|c|c|}
\hline Cost in Millions of $\mathbf{1 9 9 3}$ Dollars & Five-Well System & Three-Well System \\
\hline \hline Capital Cost & 1.13 & 0.85 \\
\hline Annual O\&M Cost & $<0.01$ & $<0.01$ \\
\hline Present Worth & 1.20 & 0.89 \\
\hline
\end{tabular}

O\&M - operating and maintenance 
DOE/RL-93-23, Rev. 0

Table 6-14 Cost Evaluation for 200 Area Crib Disposal

\begin{tabular}{||l|c|c|}
\hline Cost in Millions of 1993 Dollars & Five-Well System & Three-Well System \\
\hline \hline Capital Cost & 8.98 & 8.23 \\
\hline Annual O\&M Cost & 0.13 & 0.08 \\
\hline Present Worth & 10.02 & 8.85 \\
\hline
\end{tabular}

O\&M - operating and maintenance 
DOE/RL-93-23, Rev. 0

Table 6-15 Institutional Considerations Evaluation for Groundwater Extraction Options

\begin{tabular}{||l|l|l||}
\hline \multirow{2}{*}{ Criteria } & \multicolumn{2}{|c|}{ Evaluation } \\
\cline { 2 - 3 } & \multicolumn{1}{|c|}{ Five-Well System } & \multicolumn{1}{|c|}{ Three-Well System } \\
\hline \hline $\begin{array}{l}\text { Ability to } \\
\text { achieve removal } \\
\text { action objectives }\end{array}$ & $\begin{array}{l}\text { Achieves objectives; strontium-90 } \\
\text { flux above 1,000 pCi/L is } \\
\text { potentially completely eliminated }\end{array}$ & $\begin{array}{l}\text { Achieves objectives; strontium- } \\
90 \text { flux is restricted to a lesser } \\
\text { extent than five-well system }\end{array}$ \\
\hline $\begin{array}{l}\text { Regulatory } \\
\text { concerns about } \\
\text { the technology }\end{array}$ & $\begin{array}{l}\text { Concern should be low since } \\
\text { technology is well proven for } \\
\text { containment }\end{array}$ & Same as five-well system \\
\hline $\begin{array}{l}\text { Permitting } \\
\text { requirements }\end{array}$ & None required & None required \\
\hline Safety & $\begin{array}{l}\text { Meets ALARA with engineering } \\
\text { controls applied }\end{array}$ & Same as five-well system \\
\hline Timeliness & Meets requirements & Meets requirements \\
\hline
\end{tabular}

ALARA - as low as reasonable achievable 
DOE/RL-93-23, Rev. 0 Table 6-16 Institutional Considerations Evaluation for
Groundwater Treatment Options

\begin{tabular}{|l|l|l||}
\hline \multirow{2}{*}{ Criteria } & \multicolumn{2}{c|}{ Evaluation } \\
\cline { 2 - 3 } & \multicolumn{1}{|c|}{ Ion Exchange } & \multicolumn{1}{c|}{ Reverse Osmosis } \\
\hline \hline $\begin{array}{l}\text { Ability to achieve removal } \\
\text { action objectives }\end{array}$ & $\begin{array}{l}\text { Uncertain; treatability studies } \\
\text { required }\end{array}$ & $\begin{array}{l}\text { Uncertain; treatability } \\
\text { studies required }\end{array}$ \\
\hline $\begin{array}{l}\text { Regulatory concerns about } \\
\text { the technology }\end{array}$ & $\begin{array}{l}\text { Concern should be low since } \\
\text { technology is well proven }\end{array}$ & Same as ion exchange \\
\hline Permitting requirements & None required & None required \\
\hline Safety & Meets ALARA & Meets ALARA \\
\hline Timeliness & Meets requirements & Meets requirements \\
\hline
\end{tabular}

ALARA - as low as reasonably achievable 
DOE/RL-93-23, Rev. 0

Table 6-17 Institutional Considerations Evaluation for Treated Water Disposal Options

\begin{tabular}{|c|c|c|c|c|}
\hline \multirow{2}{*}{ Criteria } & \multicolumn{4}{|c|}{ Evaluation } \\
\hline & $\begin{array}{c}\text { River } \\
\text { Discharge }\end{array}$ & N Area Crib & $\begin{array}{l}\text { N Area } \\
\text { Injection }\end{array}$ & 200 Area Crib \\
\hline $\begin{array}{l}\text { Ability to } \\
\text { achieve removal } \\
\text { action objectives }\end{array}$ & $\begin{array}{l}\text { Achieves } \\
\text { removal } \\
\text { objectives for all } \\
\text { contaminants } \\
\text { except tritium }\end{array}$ & $\begin{array}{l}\text { Same as river } \\
\text { discharge } \\
\text { option }\end{array}$ & $\begin{array}{l}\text { Same as river } \\
\text { discharge } \\
\text { option }\end{array}$ & $\begin{array}{l}\text { Achieves all } \\
\text { objectives }\end{array}$ \\
\hline $\begin{array}{l}\text { Regulatory } \\
\text { concerns about } \\
\text { the technology }\end{array}$ & $\begin{array}{l}\text { Tritium above } \\
\text { drinking water } \\
\text { standards }\end{array}$ & $\begin{array}{l}\text { Same as river } \\
\text { discharge but } \\
\text { soil column } \\
\text { acts as buffer }\end{array}$ & $\begin{array}{l}\text { Same as river } \\
\text { discharge; } \\
\text { state not likely } \\
\text { to favor } \\
\text { injection }\end{array}$ & $\begin{array}{l}\text { Same as river } \\
\text { discharge but } \\
\text { soil column } \\
\text { acts as buffer }\end{array}$ \\
\hline $\begin{array}{l}\text { Permitting } \\
\text { requirements }\end{array}$ & NPDES & WAC $173-216$ & WAC $173-218$ & WAC $173-216$ \\
\hline Safety & Meets ALARA & Meets ALARA & Meets ALARA & Meets ALARA \\
\hline Timeliness & $\begin{array}{l}\text { Meets } \\
\text { requirements }\end{array}$ & $\begin{array}{l}\text { Meets } \\
\text { requirements }\end{array}$ & $\begin{array}{l}\text { Meets } \\
\text { requirements }\end{array}$ & $\begin{array}{l}\text { Meets } \\
\text { requirements }\end{array}$ \\
\hline
\end{tabular}

NPDES - National Pollutants Discharge Elimination System

ALARA - as low as reasonably achievable

WAC - Washington Administrative Code 
Table 6-18 Environmental Impacts Evaluation for Groundwater Extraction Options

\begin{tabular}{|c|c|c|}
\hline \multirow{2}{*}{ Criteria } & \multicolumn{2}{|c|}{ Evaluation } \\
\hline & Five-well System & Three-well System \\
\hline $\begin{array}{l}\text { Environmental impacts } \\
\text { on: } \\
\text { Topography and } \\
\text { surface drainage }\end{array}$ & No impact & No impact \\
\hline Geology & No impact & No impact \\
\hline Soils & No impact & No impact \\
\hline $\begin{array}{l}\text { Surface water } \\
\text { hydrology and } \\
\text { quality }\end{array}$ & $\begin{array}{l}\text { Some surface water will } \\
\text { flow into the pumping wells; } \\
\text { surface water quality will } \\
\text { increase through removal of } \\
\text { strontium-90 }\end{array}$ & $\begin{array}{l}\text { Same as five-well system } \\
\text { but with a lesser increase } \\
\text { in surface water quality }\end{array}$ \\
\hline $\begin{array}{l}\text { Groundwater } \\
\text { hydrology and } \\
\text { quality }\end{array}$ & $\begin{array}{l}\text { Hydrology will be impacted } \\
\text { by increasing gradients in } \\
\text { the capture zone; flow of } \\
\text { contamination toward the } \\
\text { well will be accelerated due } \\
\text { to the pumping effect }\end{array}$ & $\begin{array}{l}\text { Same as five-well system } \\
\text { but to a lesser extent }\end{array}$ \\
\hline $\begin{array}{l}\text { Meteorology } \\
\text { and air quality }\end{array}$ & No impact & No impact \\
\hline $\begin{array}{l}\text { Biological } \\
\text { resources }\end{array}$ & No impact & No impact \\
\hline $\begin{array}{l}\text { Cultural } \\
\text { resources }\end{array}$ & No impact & No impact \\
\hline $\begin{array}{l}\text { Land and water } \\
\text { use }\end{array}$ & $\begin{array}{l}\text { Water use restrictions will } \\
\text { continue; same as no action }\end{array}$ & Same as five-well system \\
\hline Visual resources & No impact & No impact \\
\hline
\end{tabular}


DOE/RL-93-23, Rev. 0

Table 6-19 Environmental Impacts Evaluation for Treated Water Disposal Options (Page 1 of 2)

\begin{tabular}{|c|c|c|c|c|}
\hline \multirow{2}{*}{ Criteria } & \multicolumn{4}{|c|}{ Evaluation } \\
\hline & $\begin{array}{c}\text { River } \\
\text { Discharge } \\
\end{array}$ & N Area Crib & $\begin{array}{l}\text { N Area } \\
\text { Injection }\end{array}$ & 200 Area Crib \\
\hline $\begin{array}{l}\text { Environmental } \\
\text { impacts on: } \\
\text { Topography } \\
\text { and surface } \\
\text { drainage } \\
\end{array}$ & No impact & $\begin{array}{l}\text { Potential slight } \\
\text { topography } \\
\text { changes from } \\
\text { crib } \\
\text { excavation }\end{array}$ & No impact & $\begin{array}{l}\text { Potential slight } \\
\text { topography } \\
\text { changes from } \\
\text { crib excavation }\end{array}$ \\
\hline Geology & No impact & No impact & No impact & No impact \\
\hline Soils & No impact & $\begin{array}{l}\text { Tritium will } \\
\text { increase in } \\
\text { disposal crib } \\
\text { soils and } \\
\text { underlying } \\
\text { groundwater } \\
\text { aquifer } \\
\text { sediments }\end{array}$ & $\begin{array}{l}\text { Contamination } \\
\text { of currently } \\
\text { clean aquifer } \\
\text { sediments with } \\
\text { tritium }\end{array}$ & $\begin{array}{l}\text { Same as } N \\
\text { Area crib }\end{array}$ \\
\hline $\begin{array}{l}\text { Surface } \\
\text { water } \\
\text { hydrology } \\
\text { and quality }\end{array}$ & $\begin{array}{l}\text { Discharge of } \\
\text { tritiated water } \\
\text { into the river } \\
\text { could impact } \\
\text { he surface } \\
\text { water in the } \\
\text { immediate } \\
\text { vicinity }\end{array}$ & $\begin{array}{l}\text { Tritiated water } \\
\text { could impact } \\
\text { near-shore } \\
\text { surface water } \\
\text { quality }\end{array}$ & $\begin{array}{l}\text { Same as N Area } \\
\text { crib }\end{array}$ & $\begin{array}{l}\text { Elimination of } \\
\text { contamination } \\
\text { impact to river }\end{array}$ \\
\hline $\begin{array}{l}\text { Groundwater } \\
\text { hydrology } \\
\text { and quality }\end{array}$ & No impact & $\begin{array}{l}\text { Local } \\
\text { groundwater } \\
\text { hydrology } \\
\text { impacted }\end{array}$ & $\begin{array}{l}\text { Same as N Area } \\
\text { crib }\end{array}$ & $\begin{array}{l}200 \text { Area } \\
\text { groundwater } \\
\text { hydrology } \\
\text { impacted; }\end{array}$ \\
\hline $\begin{array}{l}\text { Meteorology } \\
\text { and air } \\
\text { quality }\end{array}$ & No impact & No impact & No impact & No impact \\
\hline $\begin{array}{l}\text { Biological } \\
\text { resources }\end{array}$ & $\begin{array}{l}\text { Minimal } \\
\text { impact in } \\
\text { immediate } \\
\text { vicinity of } \\
\text { discharge } \\
\text { point }\end{array}$ & $\begin{array}{l}\text { No impact } \\
\text { except at river } \\
\text { flow interface }\end{array}$ & $\begin{array}{l}\text { Same as N Area } \\
\text { crib }\end{array}$ & No impact \\
\hline
\end{tabular}


DOE/RL-93-23, Rev. 0

Table 6-19 Environmental Impacts Evaluation for Treated

Water Disposal Options (Page 2 of 2)

\begin{tabular}{||l|l|l|l|l||}
\hline \multirow{2}{*}{ Criteria } & \multicolumn{4}{|c|}{ Evaluation } \\
\cline { 2 - 5 } & \multicolumn{1}{|c|}{$\begin{array}{c}\text { River } \\
\text { Discharge }\end{array}$} & N Area Crib & \multicolumn{1}{|c|}{$\begin{array}{c}\text { N Area } \\
\text { Injection }\end{array}$} & 200 Area Crib \\
\hline $\begin{array}{l}\text { Cultural } \\
\text { resources }\end{array}$ & No impact & $\begin{array}{l}\text { Minimal or no } \\
\text { impact }\end{array}$ & $\begin{array}{l}\text { Minimal or no } \\
\text { impact }\end{array}$ & $\begin{array}{l}\text { Minimal or no } \\
\text { impact }\end{array}$ \\
\hline $\begin{array}{l}\text { Land and } \\
\text { water use }\end{array}$ & $\begin{array}{l}\text { Water use } \\
\text { restricted at } \\
\text { discharge } \\
\text { point }\end{array}$ & $\begin{array}{l}\text { Same as river } \\
\text { discharge }\end{array}$ & $\begin{array}{l}\text { Same as river } \\
\text { discharge }\end{array}$ & $\begin{array}{l}\text { Same as river } \\
\text { discharge }\end{array}$ \\
\hline $\begin{array}{l}\text { Visual } \\
\text { resources }\end{array}$ & No impact & No impact & No impact & No impact \\
\hline \hline
\end{tabular}


Table 6-20 Technical Feasibility Evaluation for Slurry Wall Alternative

\begin{tabular}{|l|l||}
\hline \multicolumn{1}{|c|}{ Criteria } & \multicolumn{1}{|c|}{ Evaluation } \\
\hline \hline $\begin{array}{l}\text { Ability to comply with } \\
\text { ARAR }\end{array}$ & $\begin{array}{l}\text { Uncertain; wall intersects most of the > 42 pCi/L } \\
\text { contour; however, the effect at the ends of the wall and the } \\
\text { effects of the contaminated aquifer sediments between the } \\
\text { wall and the river are not sufficiently characterized to } \\
\text { accurately predict compliance with the proposed MCL. }\end{array}$ \\
\hline $\begin{array}{l}\text { Effectiveness in reducing } \\
\text { toxicity, mobility, or } \\
\text { volume of contamination }\end{array}$ & $\begin{array}{l}\text { Restricts the flow of water containing both strontium-90 } \\
\text { and tritium although tritiated water will flow around the } \\
\text { wall because it is not retarded by the soil }\end{array}$ \\
\hline $\begin{array}{l}\text { Demonstrated performance } \\
\text { and reliability under similar } \\
\text { conditions }\end{array}$ & $\begin{array}{l}\text { Slurry walls have been used effectively for containment } \\
\text { actions at RCRA/CERCLA sites throughout the country }\end{array}$ \\
\hline Useful life & Exceeds requirements \\
\hline Constructability & $\begin{array}{l}\text { Readily constructable but rocky soils will make } \\
\text { construction more difficult }\end{array}$ \\
\hline $\begin{array}{l}\text { Operation and maintenance } \\
\text { requirements }\end{array}$ & $\begin{array}{l}\text { Vegetative cap may be required to prevent dehydration of } \\
\text { bentonite and restore area to a more natural setting; } \\
\text { continued spring and groundwater monitoring after } \\
\text { installation }\end{array}$ \\
\hline $\begin{array}{l}\text { Environmental effects on } \\
\text { performance }\end{array}$ & $\begin{array}{l}\text { Natural flow of groundwater has the potential to } \\
\text { deteriorate the performance of the barrier over time }\end{array}$ \\
\hline $\begin{array}{l}\text { Sensitivities and } \\
\text { uncertainties }\end{array}$ & $\begin{array}{l}\text { Soil testing is needed to provide data on design of slurry } \\
\text { formulations including compatibility with the injection } \\
\text { system equipment }\end{array}$ \\
\hline
\end{tabular}

MCL - maximum contaminant level

RCRA - Resource Conservation and Recovery Act CERCLA - Comprehensive Environmental Response, Compensation, and Liability Act ARAR - applicable or relevant and appropriate requirements 
DOE\RL-93-23, Rev. 0

Table 6-21 Cost Evaluation for Slurry Wall Alternative

\begin{tabular}{||c|c|}
\hline \multicolumn{2}{|c|}{ 104-ft Deep Wall Placed 100 ft from the River } \\
\hline $\begin{array}{c}\text { Cost in Millions of } 1993 \\
\text { Dollars }\end{array}$ & Deep Soil Mixing \\
\hline \hline Capital Cost & 10.01 \\
\hline Annual O\&M Cost & 0 \\
\hline Present Worth & 10.01 \\
\hline
\end{tabular}

\begin{tabular}{||l|c|}
\hline \multicolumn{2}{|c|}{ 50-ft Deep Wall Placed $\mathbf{5 0}$ ft from the River } \\
\hline \hline $\begin{array}{c}\text { Cost in Millions of } 1993 \\
\text { Dollars }\end{array}$ & Deep Soil Mixing \\
\hline \hline Capital Cost & 6.16 \\
\hline Annual O\&M Cost & 0 \\
\hline Present Worth & 6.16 \\
\hline
\end{tabular}

O\&M - operating and maintenance 
DOE\RL-93-23, Rev. 0

Table 6-22 Institutional Considerations Evaluation for Slurry Wall Alternative

\begin{tabular}{|l|l|}
\hline \multicolumn{1}{|c|}{ Criteria } & \multicolumn{1}{|c|}{ Evaluation } \\
\hline \hline Ability to achieve removal action objectives & $\begin{array}{l}\text { Strontium-90 flux is restricted; achieves } \\
\text { objectives }\end{array}$ \\
\hline Regulatory concerns about the technology & $\begin{array}{l}\text { Concern should be low since technology is } \\
\text { well proven }\end{array}$ \\
\hline Permitting requirements & None required \\
\hline Safety & Meets ALARA \\
\hline Timeliness & Meets requirements \\
\hline
\end{tabular}

ALARA - as low as reasonably achievable 
DOE\RL-93-23, Rev. 0

Table 6-23 Environmental Impacts Evaluation for Slurry Wall Alternative

\begin{tabular}{||l|l||}
\hline \multicolumn{1}{|c|}{ Criteria } & \multicolumn{1}{|c|}{ Evaluation } \\
\hline $\begin{array}{l}\text { Environmental impacts on: } \\
\text { Topography and surface } \\
\text { drainage }\end{array}$ & No impact \\
\hline Geology & No impact \\
\hline Soils & Reduced contamination in riverbank soils \\
\hline $\begin{array}{l}\text { Surface water hydrology } \\
\text { and quality }\end{array}$ & $\begin{array}{l}\text { Improved surface water quality in the long-term as a } \\
\text { result of restricting flow of contaminants into the river; } \\
\text { near-term effects are uncertain because of the sediments } \\
\text { between the wall and the river }\end{array}$ \\
\hline $\begin{array}{l}\text { Groundwater hydrology } \\
\text { and quality }\end{array}$ & $\begin{array}{l}\text { Groundwater hydrology in the } \mathrm{N} \text { Area is altered; the } \\
\text { groundwater gradient behind the wall is decreased; the } \\
\text { gradient at the ends of the wall is increased; the wall } \\
\text { results in approximately } 1.6 \mathrm{ft}(0.5 \mathrm{~m}) \text { rise in water level } \\
\text { on the upgradient side of the wall, based on modeling } \\
\text { results }\end{array}$ \\
\hline $\begin{array}{l}\text { Meteorology and air } \\
\text { quality }\end{array}$ & \begin{tabular}{l} 
No impact \\
\hline Biological resources
\end{tabular} \\
\hline Cultural resources & Less threat to riparian and aquatic biota \\
\hline Land and water use & No impact \\
\hline Visual resources & No impact \\
\hline
\end{tabular}


Table 6-24 Technical Feasibility Evaluation for Hydraulic Control Alternative

\begin{tabular}{||l|l||}
\hline \multicolumn{1}{|c|}{ Criteria } & \multicolumn{1}{|c|}{ Evaluation } \\
\hline \hline Ability to comply with ARAR & $\begin{array}{l}\text { Flow of contamination to river is restricted but } \\
\text { alternative does not meet chemical-specific } \\
\text { ARAR }\end{array}$ \\
\hline $\begin{array}{l}\text { Effectiveness in reducing toxicity, } \\
\text { mobility, or volume of contamination }\end{array}$ & $\begin{array}{l}\text { Restricts the flow of water containing strontium- } \\
90 \text { and tritium }\end{array}$ \\
\hline $\begin{array}{l}\text { Demonstrated performance and } \\
\text { reliability under similar conditions }\end{array}$ & $\begin{array}{l}\text { Hydraulic control has been used effectively for } \\
\text { containment actions at RCRA/CERCLA sites }\end{array}$ \\
\hline Useful life & Meets requirements \\
\hline Constructability & Readily constructable \\
\hline $\begin{array}{l}\text { Operation and maintenance } \\
\text { requirements }\end{array}$ & $\begin{array}{l}\text { System is not complex and easy to operate; some } \\
\text { maintenance required for pumps }\end{array}$ \\
\hline Environmental effects on performance & $\begin{array}{l}\text { Changing hydrologic conditions could affect } \\
\text { system performance }\end{array}$ \\
\hline Sensitivities and uncertainties & $\begin{array}{l}\text { Uncertainties in hydrologic properties and } \\
\text { heterogeneities of the flow system }\end{array}$ \\
\hline
\end{tabular}

ARAR - applicable or relevant and appropriate requirements

RCRA - Resource Conservation and Recovery Act

CERCL.A - Comprehensive Environmental Response, Compensation, and Liability Act 
DOE \RL-93-23, Rev. 0

Table 6-25 Cost Evaluation for Hydraulic Control Alternative

\begin{tabular}{|l|c|}
\hline \multicolumn{1}{|c|}{$\begin{array}{c}\text { Cost in Millions of 1993 } \\
\text { Dollars }\end{array}$} & $\begin{array}{c}\text { Hydraulic Control } \\
\text { System }\end{array}$ \\
\hline \hline Capital Cost & 2.30 \\
\hline Annual O\&M Cost & 0.07 \\
\hline Present Worth & 2.85 \\
\hline
\end{tabular}

O\&M - operating and maintenance 
DOE $\backslash$ RL-93-23, Rev. 0

Table 6-26 Institutional Considerations Evaluation for Hydraulic Control Alternative

\begin{tabular}{||l|l|}
\hline \multicolumn{1}{|c|}{ Criteria } & \multicolumn{1}{c|}{ Evaluation } \\
\hline \hline $\begin{array}{l}\text { Ability to achieve removal action } \\
\text { objectives }\end{array}$ & $\begin{array}{l}\text { Strontium-90 flux is restricted; achieves } \\
\text { objectives }\end{array}$ \\
\hline $\begin{array}{l}\text { Regulatory concerns about the } \\
\text { technology }\end{array}$ & $\begin{array}{l}\text { Concern should be low since technology is } \\
\text { proven in the field }\end{array}$ \\
\hline Permitting requirements & None required \\
\hline Safety & No contaminated water is pumped \\
\hline Timeliness & Meets requirements \\
\hline
\end{tabular}


DOE\RL-93-23, Rev. 0

Table 6-27 Environmental Impacts Evaluation for Hydraulic Control Alternative

\begin{tabular}{||l|l||}
\hline \multicolumn{1}{|c|}{ Criteria } & \multicolumn{1}{|c|}{ Evaluation } \\
\hline $\begin{array}{c}\text { Environmental impacts on: } \\
\text { Topography and } \\
\text { surface drainage }\end{array}$ & No impact \\
\hline Geology & No impact \\
\hline Soils & Reduced contamination in riverbank soils \\
\hline $\begin{array}{l}\text { Surface water } \\
\text { hydrology and quality }\end{array}$ & $\begin{array}{l}\text { Improved surface water quality as a result of restricting } \\
\text { flow of contaminants into the river }\end{array}$ \\
\hline $\begin{array}{l}\text { Groundwater } \\
\text { hydrology and quality }\end{array}$ & $\begin{array}{l}\text { Groundwater hydrology in the N Area is altered, } \\
\text { groundwater quality remains the same }\end{array}$ \\
\hline $\begin{array}{l}\text { Meteorology and air } \\
\text { quality }\end{array}$ & No impact \\
\hline Biological resources & $\begin{array}{l}\text { Less threat to riparian and aquatic biota as a result of } \\
\text { reducing contamination flux to the river }\end{array}$ \\
\hline Cultural resources & No impact \\
\hline Land and water use & No impact \\
\hline Visual resources & Minimal impact; wells are visible but not intrusive \\
\hline
\end{tabular}




\subsection{COMPARATIVE ANALYSIS OF REMOVAL ACTION ALTERNATIVES}

This section provides comparisons of the four alternatives evaluated in Section 6.0. Each alternative is compared against the others in relation to the evaluation criteria. Costbenefits of the alternatives are compared based on correlation of cost with the estimated percentages of strontium -90 reductions achieved by each alternative.

\subsection{ALTERNATIVE COMPARISONS}

Comparisons of the alternatives based on the evaluation criteria are summarized in the subsections below.

\subsubsection{Technical Feasibility}

7.1.1.1 Ability to Comply with ARAR. Ability to comply with the proposed MCL for strontium-90 is uncertain for all the alternatives. All alternatives, except for no action, reduce the flux of contamination to the river to some degree. Based on existing modeling, the 5-well pump and treat results in the greatest reduction of flux with the 3-well and slurry wall having lower flux reductions which are roughly equal. The hydraulic control reduces the strontium-90 flux the least. These relationships are based on the flux reduction at $33 \mathrm{ft}$ $(10 \mathrm{~m})$ from the river across a 2,800-ft $(853-\mathrm{m})$ zone (see further discussion in Section 7.2). The flux at either end of this flux line has not been quantified by the modeling efforts. In addition, the location of the wall significantly affects the effectiveness at reducing the flux. Additional modeling to quantify the flux across the entire model and the optimization of the slurry wall and pumping well placement are needed to compare all the alternatives on a more equitable basis.

None of the alternatives meet the proposed tritium MCL for surface or groundwater discharge. While the 200 Area crib disposal option for pump and treat prevents tritium discharge to surface water above the MCL, discharging the water to groundwater at the 200 Area may require an ARAR waiver. The slurry wall potentially reduces the level of tritium reaching the river through the creation of a longer flow path. It is also possible that the pump and treat option may result in concentrations below the proposed MCL because of dilution by inflowng river water.

Location-specific and action-specific ARAR are generally met by all the alternatives. Some additional analysis of the wetland and Wild and Scenic Rivers Act issues is warranted in the design phase.

7.1.1.2 Effectiveness in Reducing Toxicity, Mobility, or Volume of Contamination. All alternatives except no action reduce the flux of strontium- 90 to the river, but to a different extent depending upon the technology or process option. However, all alternatives, except no action, meet the removal action objective of eliminating or substantially reducing the flux of strontium-90 to the river. 
The pump and treat options reduce both the mobility and volume of contamination by the removal of the strontium-90 from the groundwater stream. The 5-well system performs better than the 3-well system because it intercepts more of the plume. The slurry wall and hydraulic control alternatives reduce the mobility of the contaminants.

\subsubsection{Demonstrated Performance and Reliability Under Similar Conditions. All} technologies have been proven in field applications that are similar to the proposed application. Reliability of all removal action technologies is considered good, although the vertical barrier is the least complex and therefore the most reliable. The pump and treat alternative is the most complex because it involves extraction, treatment, maintenance, and disposal operations; therefore, reliability may be less than the other alternatives.

7.1.1.4 Useful Life. All alternatives meet the requirement of this ERA for a 10-year useful life. All the alternatives can be easily incorporated into future remedial actions for the operable unit.

7.1.1.5 Constructability. All alternative systems are readily constructable.

Constructability of the vertical barrier is less certain than the others because of Hanford's rocky soils.

7.1.1.6 O\&M Requirements. The pump and treat alternative requires the most O\&M; the vertical barrier requires the least. Hydraulic control O\&M requirements are low. For pump and treat, river disposal requires the least O\&M, while 200 Area crib disposal requires the most.

7.1.1.7 Environmental Effects on Performance. None of the alternatives are sensitive to environmental effects such as weather or terrain. The pump and treat alternative requires protection from freezing; however, this is addressed by enclosing the treatment system in a heated building.

7.1.1.8 Sensitivities and Uncertainties. With the exception of the no action alternative, all the alternatives are feasible for application at N Springs. However, because none of the technologies has been applied at Hanford Site conditions, the technical feasibility has some uncertainties. For the slurry wall, the uncertainty of installation in the rocky soils is a concern. Field testing is recommended to assess the impacts of the gravels and boulders on the deep soil mixing slurry wall and to optimize slurry formulations. For pump and treat, uncertainties lie in the ability to treat the groundwater to meet discharge levels. Treatability testing is necessary before performance factors can be confidently assessed. Both ion exchange and reverse osmosis treatment options generate substantial volumes of secondary waste. In the case of ion exchange, the volume of solid zeolite resins requiring disposal as low-level waste depends upon the media loading capacity. This loading capacity is sensitive to influent concentrations, including content of noncontaminants, such as calcium and nonradioactive strontium, and to the decontamination factors required. Disposal of tritiated water is another uncertainty associated with the pump and treat alternative, both in terms of institutional considerations and cost. The hydraulic control option has uncertainties associated with efficiency and the potential for increased contamination of clean areas. 
Capture effectiveness for the pump and treat will be influenced by hydraulic conductivity. If conductivities are higher than modeled, higher pumping rates would be required for effective capture which directly affects treatment system size and design. Heterogeneities in the aquifer sediments could also produce adverse effects on contaminant capture. The slurry wall would be affected by the possible irregular contact between the aquifer and underlying confining layer.

Hydraulic control is very sensitive to hydrologic properties and aquifer heterogeneities. If hydraulic conductivities are higher than modeled, pumping rates would have to be increased to maintain the same effect on downgradient water levels. However, higher pumping rates present a greater risk of drawing contamination further upgradient. Aquifer heterogeneities in the form of flow channels could also result in upgradient flow of contamination and lower effectiveness in controlling gradients in the intended portion of the plume.

\subsubsection{Cost Considerations}

The present worth of the alternatives, including options within the pump and treat alternative, are compared in Table 7-1. As indicated in the table, present worth (excluding no action) ranges from a low of about $\$ 2.74$ million for the hydraulic cuntrol alternative to a high of over $\$ 22$ million for a five-well pump and treat using ion exchange treatment and 200 Area crib disposal.

The cost analysis indicates that among the pump and treat options, cost is most sensitive to the system size in terms of flowrate from the wells, followed by the type of water disposal, and finally to the type of treatment. Cost differentials between a three-well and five-well system are on the order of \$3-6 million. Cost differentials between river disposal and 200 Area crib disposal are on the order of $\$ 8$ to $\$ 10$ million. Cost differentials between reverse osmosis and ion exchange treatment were estimated to be $\$ 2$ to $\$ 4$ million based on ventor information. However, the cost differences between reverse osmosis and ion exchange treatment are uncertain. It is possible that reverse osmosis is more costly than ion exchange, but costs cannot be refined further without treatability studies. Costs for extraction wells are fairly certain because they are based on well-defined, historical drilling costs at Hanford. Costs for treated water disposal carry moderate uncertainties in that, even though the systems are straightforward, costs for pipelines and cribs are subject to further refinement with greater design definition. Additional uncertainties include disposal costs and operating downtime. The disposal costs for secondary wastes for the ion exchange system are significant. Any reduction in the disposal costs has a corresponding reduction in the present worth. However, at this time, no other disposal options are available. Potential disposal to the ERDF can be considered in the future, but at this time the costs are not available. The operating costs are highly dependant on downtime and on the ability to conduct the treatment as a CERCLA cleanup. If the treatment system is required to be designed, constructed, and operated as a nuclear facility, then the costs would be increased significantly. 
Costs for slurry wall installation are based solely on estimates provided by vendors, although two vendors provided estimates that were on the same order of magnitude. Both vendors state that field testing is required to determine optimum slurry mixes. Costs for the slurry wall will likely change as site-specific design is performed. The major cost uncertainties associated with slurry wall installation are those that relate to unexpected field conditions, (e.g., encountering large boulders [ $>3 \mathrm{ft}$ diameter]) that interfere with augering. Placement of the wall closer to the river would result in significant cost savings because the wall depth would be reduced approximately $50 \%$. However, placing the wall closer to the river requires a wetlands assessment. This issue can be more fully addressed in the design phase of the ERA.

Costs for hydraulic control are fairly certain because they are based primarily on historical well installation costs. There is more uncertainty in the costs of installing a water pipeline to the river.

\subsubsection{Institutional Considerations}

7.1.3.1 Ability to Achieve Removal Action Objectives. All alternatives, except no action, meet the removal action objective of eliminating or substantially reducing strontium-90 flux to the river. The five-well pump and treat and the vertical barrier are potentially more effective in reducing the flux relative to the other alternatives, depending on the placement of the slurry wall.

7.1.3.2 Regulatory Concerns about the Technology. All technologies are proven for site remediation and thus should not raise concern among the regulators.

7.1.3.3 Permitting Requirements. The pump and treat alternative will require that substantive requirements of permitting regulations be met for disposal of the treated water. For example, river discharge requires meeting NPDES requirements. The vertical barrier and hydraulic control alternatives should not trigger any permit requirements; however, a wetlands assessment may be warranted depending on the slurry wall location.

7.1.3.4 Safety. All alternatives will meet ALARA requirements through application of standard control for construction and operation. Pump and treat will require appropriate controls for handling treatment residues. Some shielding may be required on vessels where strontium-90 is concentrated, although shielding will be modest because there are no significant concentrations of gamma emitters.

7.1.3.5 Timeliness. All alternatives can be implemented within a time frame that meets ERA objectives. Pump and treat will require treatability studies prior to design of treatment systems. The slurry wall will require field testing of slurry formulations and a demonstration of implementability in Hanford soils. Hydraulic control can be implemented in the shortest time frame. 


\subsubsection{Environmental Impacts}

All alternatives, except no action, will impact the river positively by reducing the flux of strontium-90 in the riverbank springs. This will benefit riparian biota and downstream water users. All alternatives, except for no action, will alter groundwater hydrology in the area of the plume; however, this will not cause impacts to human health or the environment. All alternatives will continue to require land use restrictions and restrictions on use of water from the contaminated portions of the aquifer.

\subsection{COST-PENEFIT INALYSIS}

Cost-benefit of each alternative is analyzed by correlating present worth costs to estimated reductions in strontium-90 flux as a percentage of no action (benefit). The result of this analysis is shown graphically in Figure 7-1. In this figure, the estimated percent reduction in strontium-90 flux to the river is plotted as the abscissa against the present worth cost is the ordinate. The percent reduction is derived from the modeling results. The flux of strontium-90 was modeled for the no action, three-well and five-well pump and treat, and slurry wall alternative systems being placed $100 \mathrm{ft}(30 \mathrm{~m})$ from the river. The flux was measured along a 2,800-ft $(853-\mathrm{m})$ flux line located parallel to and $33 \mathrm{ft}(10 \mathrm{~m})$ from the river. The totai curies of strontium-90 passing the flux line for each alternative are compared to the total for the no action scenario. These percentages are then plotted against the costs for the individual alternatives to graphically represent the cost-benefit of each alternative.

The figure is representative of the existing modeling only. One of the uncertainties associated with the slurry wall is the placement distance of the wall from the river. If the wall is placed $100 \mathrm{ft}(30 \mathrm{~m})$ from the river, the flux reduction is nearly $100 \%$ at the wall, but is only about $71 \%$ at the flux line $33 \mathrm{ft}(10 \mathrm{~m})$ from the river. This is because the strontium-90 remaining in the area between the wall and the river continues to flush into the river and because of the small quantity of strontium- 90 in the water flowing around the ends of the wail. If the slurry wall is placed at the river, the flux reduction is nearly $100 \%$. Any placement of the wall between the river and $100 \mathrm{ft}(30 \mathrm{~m})$ would result in a flux reduction between $71 \%$ and $100 \%$. Placement cannot be optimized from the existing modeling.

A major benefit of moving the wall closer to the river is the significant reduction in cost. By placing the wall $50 \mathrm{ft}(15 \mathrm{~m})$ from the river the depth of the wall is reduced by one-half. Cost of the wall is reduced from $\$ 10$ million to about $\$ 6$ million (assuming a scaling of depth of the wall using a 0.7 capital cost scaling factor). Placement of the wall $50 \mathrm{ft}(15 \mathrm{~m})$ from the river would require a wetlands assessment.

The hydraulic control option was modeled only with the FLOWPATH model and not with PORFLO-3; therefore a similar comparison cannot be made with this option. The percent reduction value for the hydraulic control alternative is based on capture zone analysis of the groundwater flux to the river. 
Note that in the figure the no action and hydraulic control alternatives plot as a single point. However, the slurry wall and pump and treat alternative options plot as a range. Ranges are shown for the three-well and five-well extraction systems. The cost range for each of the pumping options reflects the cost differences in the treated water disposal options and in the treatment options. The figure reflects those parameters which could be quantified for this ERA. However, uncertainties may lie in both the costs and effectiveness of the alternatives. The effectiveness of the slurry wall is related to placement. Likewise the pump and treat costs may be slightly higher or lower. However, these uncertainties cannot be quantified with existing data. The information shown on the figure represents the modeling results, professional judgement, and current data available for the $\mathrm{N}$ Spring area. Further analysis at this stage would require unsupportable assumptions which would not decrease the level of uncertainty.

Based on analysis of the cost-benefit relationship of Figure 7-1, several generalizations and conclusions can be reached. These are discussed as follows:

- Additional information is needed prior to implementation of a preferred alternative.

- $\quad$ For the pump and treat options, river disposal appears to be the best choice among all treated water disposal options, especially considering the proposed MCL for tritium. Current tritium levels are very close to this proposed value. The $100 \mathrm{~N}$ Area reinjection and the $100 \mathrm{~N}$ Area crib disposal option do not offer significant additional benefit for handling tritium but result in substantially greater costs. Further, the benefit of crib disposal and reinjection are considered negative, since either may result in contamination of additional aquifer sediments or mobilization of resident contaminants. Disposal at a 200 Area crib offers better protection of the river but results in further aquifer sediment contamination and greater expense.

- Based on existing modeling, the five-well system appears to offer the highest level of flux reduction. The slurry wall may provide equivalent effectiveness if properly placed; however, additional analysis is necessary to determine this effectiveness.

- $\quad$ Secondary waste considerations, such as the tritiated water, reverse osmosis reject stream, and spent ion exchange media, are a drawback for the pump and treat alternatives. The slurry wall and hydraulic control are not constrained by these secondary waste issues.

- For the slurry wall and hydraulic control alternatives, the potential to contaminate clean aquifer material exists. 
- Hydraulic control offers the lowest cost; however, the uncertainties associated with the hydraulic control alternative are greater than the other alternatives. The modeling shows that upgradient hydraulic control could achieve approximately a $50 \%$ reduction in strontium-90 flux without drawing the contamination into clean areas. This reduction could be worse if hydraulic conductivity is higher or if significant flow channels are present. 
DOE\RL-93-23, Rev. 0

Figure 7-1 Cost Benefit Analysis of Alternatives

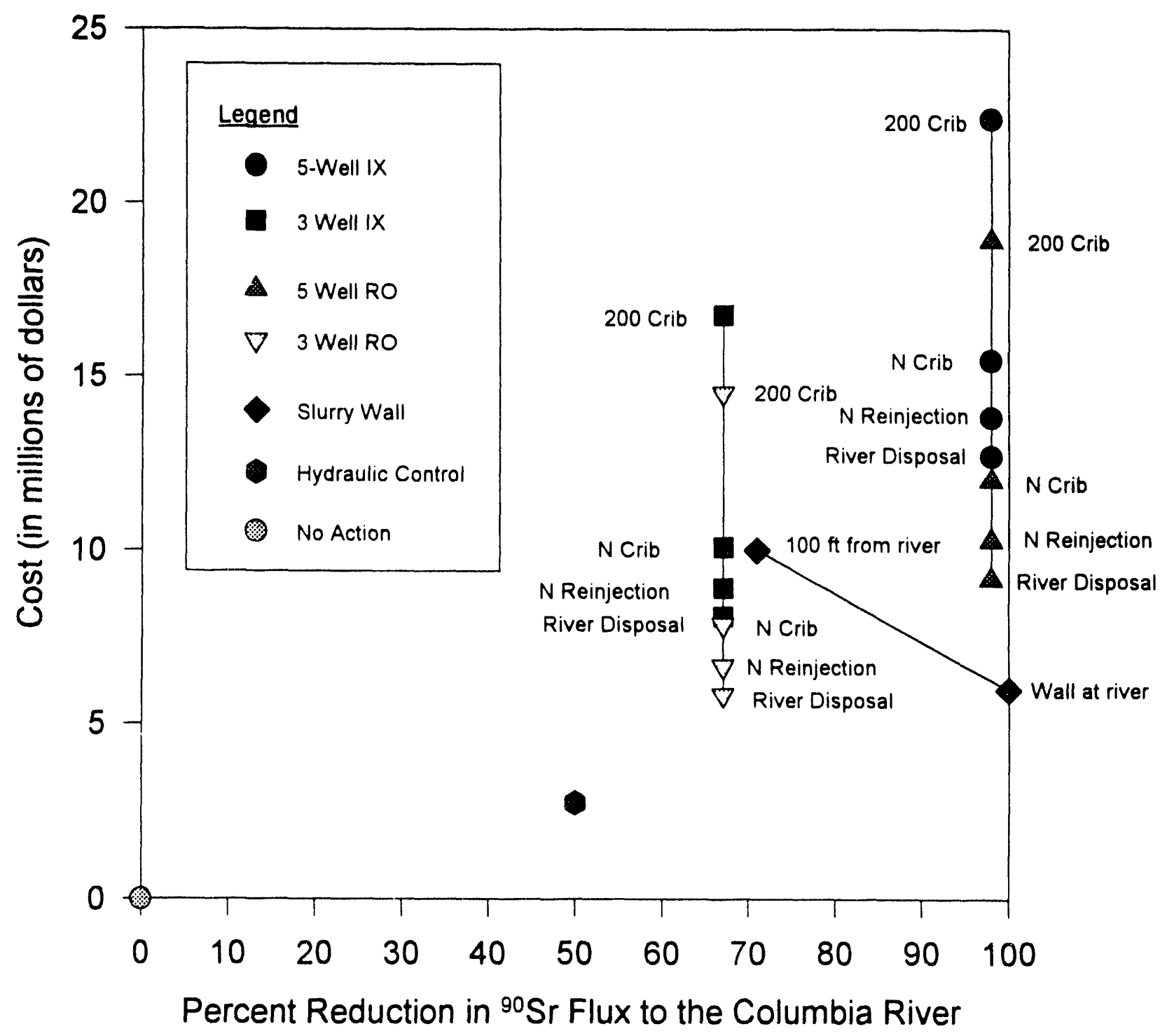


DOE $\backslash$ RL-93-23, Rev. 0

Table 7-1 Cost Comparison of Alternatives

\begin{tabular}{|lcc|}
\hline \multicolumn{3}{|c|}{ Alternative Present Worth Comparisons } \\
(In Millions of \$)
\end{tabular}




\subsection{PREFERRED ALTERNATIVE}

The preferred alternative should provide a high degree of protectiveness balanced with acceptable risks and reasonable costs. However, as a result of the additional analysis performed in response to regulatory comments, it is now concluded that a preferred alternative cannot be confidently recommended in view of the technical and cost uncertainties of both alternatives. Therefore, both the slurry wall and the pump and treat alternatives are recommended as preferred alternatives. Additional information may be needed prior to implementing a single preferred action. The following activities are proposed to gather this information:

- $\quad$ Time consistent groundwater and spring sampling - All wells associated with the $N$ Springs area and the strontium-90 plume, including the wells at the springs, should be sampled at the same time to allow construction of representative contaminant plume maps. This information will be used to construct the groundwater model.

- Additional groundwater flow and contaminant transport modeling for the alternatives - The model will be constructed specifically for the evaluation of these alternatives using current $N$ Springs area conditions. The model will be used to evaluate performance of the alternatives including hydraulic control to optimize elements of each alternative, such as wall length and placement, well spacing, and well pumping rates, and to determine remediation time frames.

- $\quad$ Subsurface characterization - Two borings will be drilled to define the confining layer depth and thickness. Sediment samples from the aquifer will be collected to determine aquifer physical parameters including strontium- 90 sorption characteristics.

- $\quad$ Slurry wall implementability test - A test panel using the deep soil mixture equipment will be constructed in a clean zone in the $100 \mathrm{~N}$ Area. Slurry formulations consistent with the $\mathrm{N}$ Springs area water and soils will be developed. Following placement of the test panel, the panel will be drilled to determine if the panel meets permeability criteria.

- $\quad$ Treatability studies for ion exchange and reverse osmosis treatment systems A bench-scale treatability study will be conducted for the ion exchange treatment system. Information will be generated (in coordination with other treatability tests being conducted on-site) on appropriate ion exchange media, media loading, waste generation, and costs. A pilot-scale reverse osmosis treatability test will be conducted in the field to determine an acceptable membrane, membrane loading, waste generation, waste water treatment, and cost. 
- Wetlands regulatory review/assessment - A regulatory review will be conducted to determine the requirements needed to conduct the ERA near the river. Wetlands, floodplain, and Wild and Scenic Rivers Act regulations will be reviewed to identify requirements; appropriate federal and state agencies will be contacted if necessary. If warranted, a wetlands assessment will be conducted prior to alternative implementation. This issue directly affects the location, size, effectiveness, and cost of the slurry wall.

- Endangered vegetation study - A study of endangered species located at the $\mathbf{N}$ Springs area will be conducted to identify potential impacts.

- Additional analysis and refinement of costs - The cost estimates will be refined based on the additional information gathered in the other activities.

The information gathered from the above activities will be used to implement the preferred alternative. This preferred alternative will continue through the design phase and ultimately be implemented. 
DOE $\backslash$ RL-93-23, Rev. 0

\subsection{SCHEDULE}

Figure $9-1$ is a schedule for the modeling, characterization, and testing program proposed for the design phase of the ERA. In addition, the schedule in Figure 9-1 includes the construction and implementation phases of the ERA. 


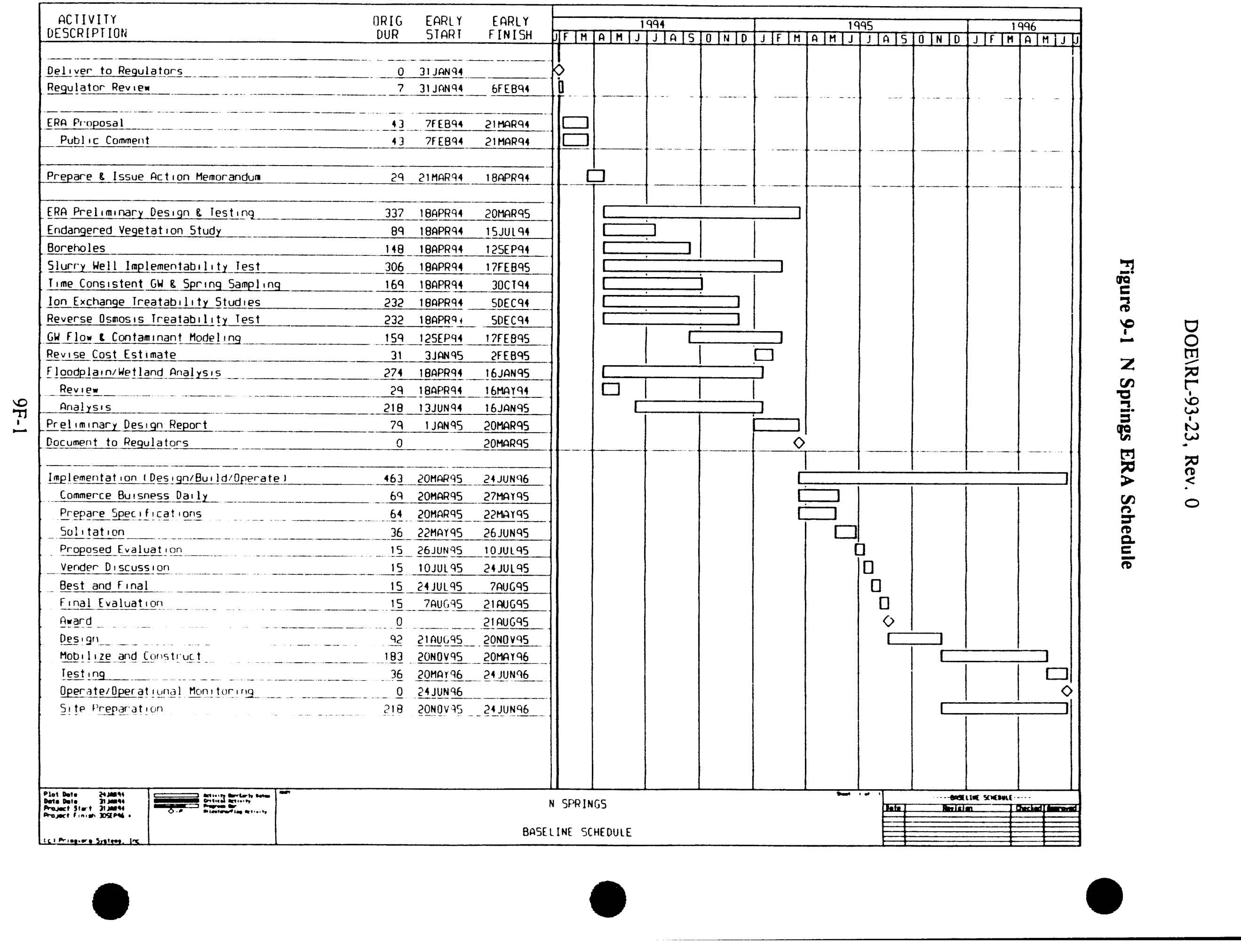




\subsection{REFERENCES}

Baker, V. R., B. N. Bjornstad, A. J. Busacca, K. R. Fecht, E. P. Kiver, U. L. Moody, J. G. Rigby, D. F. Stradling, and A. M. Tallman, 1991, "Quarternary Geology of the Columbia Plateau," in Quarternary Nonglacial Geology; Conterminous United States, R. B. Morrison (editor), Geological Society of America, the Geology of North America, v. K-2, p. 215-250, Boulder, Colorado.

Black, R. F., 1979, Clastic Dike: of the Pasco Basin, Soucheastern Washington, RHO-BWIC-64, Rockwell Hanford Operations, Richland, Washington.

Bauer, D. J. and J. J. Vaccaro, 1990, Estimates of Ground-Water Recharge to the Columbia Plateau Regional Aquifer System, Washington, Oregon, and Idaho, for Predevelopment and Current Land-Use Conditions, Water Resources Investigations Report 88-4108, U.S. Geological Survey, Tacoma, Washington.

Brown, D. J. and P. P. Rowe, 1960, 100-N Area Aquifer Evaluation, HW-6736, General Electric Company, Hanford Atomic Products Operation, Richland, Washington.

Buske, N., and L. Josephson, 1988, Water Sediment Reconnaissance of the Hanford Shoreline, Hanford Reach Project, Data Report 4, Fall 1988, SEARCH Technical Services, Davenport, Washington, published by Hanford Education Action League, Spokane, Washington.

Chatters, J.C., H.A. Gard, and P.E. Minthorn, 1992, Fiscal Year 1991 Report on Archaeological Surveys of the 100 Areas, Hanford Site, Washington, PNL-8143, Pacific Northwest Laboratory, Richland, Washington.

Chatters, J.C., N.A. Cadoret, and P.E. Minthorn, 1990, Hanford Cultural Resources Laboratory Annual Report for Fiscal Year 1989, PNL-7362, Pacific Northwest Laboratory, Richland, Washington.

Chatters, J.C. (ed.), 1989, Hanford Cultural Resources Management Plan, PNL-6942, Pacific Northwest Laboratory, Richland, Washington.

Connelly, M. P., J. D. Davis, and P. D Rittman, 1991, Numerical Simulation of Strontium90 Transport from the 100-N Area Liquid Waste Disposal Farilities, WHC-SD-ER-TA-001, Westinghouse Hanford Company, Richland, Washington.

Crews, W.S., and D. D. Tillson, 1969, Analysis of Travel Time of 1-131 from the 1301-N Crib to the Columbia River During July 1969, BNWL-CC-2326, Battelle Pacific Northwest Laboratory, Richland, Washington.

Cushing, C.E. (ed.), 1991, Hanford Site National Environmental Policy Act Characterization, Pacific Northwest Laboratory, Richland, Washington. 
Dash, J. G., 1991, "Ice Technology for Hazardous Waste Management," Waste Management, Volume 11.

Daubenmire, R., 1970, Steppe Vegetation of Washington, Technical Bulletin 62, Experimental Station, Washington State University, Pullman, Washington.

Dirkes, R. L., 1992, Columbia River Monitoring Data Compilation, WHC-SD-EN-DP-024, Rev. 0, Pacific Northwest Laboratory, Richland, Washington.

Dirkes, R. L., 1990, 1988 Hanford Riverbank Springs Characterization Report, PNL-7500, Pacific Northwest Laboratory, Richland, Washington.

DOE, 1990, Installation Work Plan for Environmental Restoration, LA UR-90 3825, Vol.1, Los Alamos National Laboratory, Los Alamos, New Mexico.

DOE, 1988, Site Characterization Plan, Reference Repository Location, Hanford Site. Washington: Consultation Draft, DOE/RW-0164, U.S. Department of Energy, Office of Civilian Radioactive Waste Management, Washington, D.C.

DOE-RL, 1993, 100 Area Feasibility Siudy, Phases I and 2, DOE/RL-92-11, U.S. Department of Energy, Richland, Washington.

DOE-RL, 1992a, Sampling and Analysis of 100 Area Springs, DOE/RL-92-12, Rev. 1, U.S. Department of Energy, Richland, Washington.

DOE-RL, 1992b, RCRA Facility Investigation/Corrective Measures Study Work Plan for the 100-NR-2 Operable Unit, Hanford Site, Richland, Washington, DOE/RL-90-23, U.S. Department of Energy, Richland, Washington.

DOE-RL, 1991a, Hanford Past-Practice Strategy, DOE/RL-91-40, Draft A, U.S. Department of Energy, Richland, Washington.

DOE-RL, 1991b, RCRA Facility Investigation/Corrective Measures Study Work Plan for the 100-NR-1 Operable Unit, Hanford Site, Richland, Washington, DOE/RL-90-22, U.S. Department of Energy, Richland, Washington.

Ecology, EPA, and DOE, 1993, Hanford Federal Facility Agreement and Consent Order Change Package, dated January 8, 1993, Richland, Washington.

Ecology, EPA, and DOE, 1991, Hanford Federal Facility Agreement and Consent Order Change Package, dated May 13, 1991, Richland. Washington.

Ecology, EPA, and DOE, 1990, Hanford Federal Facility Agreement and Consent Order, First Amendment, 89-10 Rev. 1, Richland, Washington.

Ecology, EPA, and DOE, 1989, Hanford Federal Facility Agreement and Consent Order, Richland, Washington. 
EPA, 1990, Handbook of In Situ Treatment of Hazardous Waste-Contaminated Soils, EPA/540/2-90/002, U.S. Environmental Protection Agency, Risk Reduction Engineering Laboratory, Cincinnati, Ohio.

EPA, 1987a, Drafi Engineering Evaluation/Cost Analysis Guidance for Non-Time-Critical Removal Actions, U.S. Environmental Protection Agency.

EPA, 1987b, A Compendium of Technologies in the Treatment of Hazardous Wastes, EPA/625/8-87/014, U.S. Environmental Protection Agency, Cincinnati, Ohio.

EPA, 1985, Remedial Action at Waste Disposal Sites, EPA/625/6-85/006, U.S. Environmental Protection Agency, Office of Research and Development, Cincinnati, Ohio.

Faison, B.D., C.A. Cancel, S.N. Lewis, H.I. Adler, 1990, "Binding of Dissolved Strontium by Micrococcus Luteus," Applied and Environmental Biology, Dec. 1990, pp. 3649 3656

Fitzner, R. E. and S. G. Weiss, 1992, Bald Eagle Site Management Plan for the Hanford Site, South Central Washington, Westinghouse Hanford Company, Richland, Washington.

Franz, T. and N Gieguer, 1991, 2-D Horizontal Aquifer Simulation Program, Waterloo Hydrogeologic, FLOWPATH-EM 4.2, Licence \# fp420.929.

Freeman, H. M., 1989, Standard Handbook of Hazardous Waste Treatment and Disposal, McGraw-Hill Inc., New York, New York.

Gee, G. W., 1987, Recharge at the Hanford Site: Status Report, PNL-6403. Pacific Northwest Laboratories, Richland, Washington.

Gilmore, T. J., F. A. Spane Jr., D. R. Newcomer, and C. R. Sherwood, 1992, Applications of Three Aquifer Test Methods for Estimating Hydraulic Properties within the 100-N Area, PNL-8335, Pacific Northwest Laboratory, Richland, Washington.

Gilmore, T. J., J. V. Borghese, and D. R. Newcomer, 1991, Letter Report: Evaluations of the Effects of the Columbia River on the Unconfined Aquifer Beneath the 100-N Area/Phase 3, in "Evaluations of the Effects of the Columbia River on the Unconfined Aquifer Beneath the 100-N Area," PNL-7646, Pacific Northwest Laboratory, Richland, Washington.

Gilmore, T. J., J. V. Borghese, J. P. McDonald, and D. R. Newcomer, 1990, Evaluation of the Effects of the Columbia River on the Unconfined Aquifer Beneath the 1301-N Liquid Waste Disposal Faciliry, PNL-7341, Pacific Northwest Laboratory, Richland, Washington. 
Gustafson, F. W., 1991, Site Selection Process for Expedited Response Actions at the Hanford Site, WHC-MR-0290, Westinghouse Hanford Company, Richland, Washington.

Hajek, B. F., 1966, Soil Survey: Hanford Project in Benton County, Washington, BNWL243, Pacific Northwest Laboratory, Richland, Washington.

Hartman, M. J., 1993a, Groundwater Monitoring Plan for 1301-N and 1325-N Facilities, WHC-SD-EN-AP-038, Rev.1, Westinghouse Hanford Company, Richland, Washington.

Hartman, M. J., 1993b, "100-N Area RCRA Sites", in Annual Report for RCRA Groundwater Monitoring Project at Hanford Site Facilities for 1992, DOE/RL-93-09, U.S. Department of Energy, Richland, Washington.

Hartman, M. J., 1992, Borehole Completion Data Package for Wells 199-N-71, 199-N-72, 199-N-73, and 199-N-74, WHC-SD-EN-DP-040, Westinghouse Hanford Company, Richland, Washington

Hartman, M. J. and K. A. Lindsey, 1993, Hydrogeology of the 100-N Area, WHC-SD-ENEV-027, Westinghouse Hanford Company, Richland, Washington.

Hunt, C. B., 1974, Natural Regions of the United States and Canada, W. H. Freeman and Company, San Francisco, California.

IT Corporation, 1992, $N$ Springs Expedited Response Action Project Plan, WHC-SD-ENTPP-002, Rev. 0, Westinghouse Hanford Company, Richland, Washington.

Lindberg, J. W., 1993a, Geology of the 100-BC Area, Hanford Site, South Central Washington, WHC-SD-EN-TI-133, Rev. 0, Washington Hanford Company, Richland, Washington.

Lindberg, J. W., 1993b, Geology of the 100-K Area, Hanford Site, South Central Washington, WHC-SD-EN-TI-155, Westinghouse Hanford Company, Richland, Washington.

Lindsey, K. A., 1992, Geology of the Northern Part of the Hanford Site: An Outline of Data Sources and the Geologic Setting of the 100 Areas, WHC-SD-EN-TI-011, Westinghouse Hanford Company, Richland, Washington.

Lindsey, K. A., 1991, Revised Stratigraphy for the Ringold Formation, Hanford Site, Southcentral Washington, WHC-SD-EN-EE-004 Rev. 0, Westinghouse Hanford Company, Richland, Washington.

Lindsey, K. A. and G. K. Jaeger, 1993, Geologic Setting of the 100-HR-3 Operable Unit, Hanford Site, South-central Washington, WHC-SD-EN-TI-132, Westinghouse Hanford Company, Richland, Washington. 
Manley, C. L., and L. P. Diediker, 1992, Environmental Releases for Calendar Year 1990. Westinghouse Hanford Company, Richland, Washington.

McCormack, W. D. and J. M. V. Carlile, 1984, Investigation of Groundwater Seepage from the Hanford Shoreline of the Columbia River, PNL-5289, Pacific Northwest Laboratory, Richland, Washington.

NRC, 1981, Volume Reduction Techniques in Low-Level Radioactive Waste Management. NUREG/CR-2206, U.S. Nuclear Regulatory Commission, Washington, D.C.

Perkins, C. J., 1992, Westinghouse Hanford Company Environmental Surveillance Annual Report-100 Areas: Calendar Year 1990, WHC-EP-0258-2, Westinghouse Hanford Company, Richland, Washington.

Perkins, C. J., 1989, Characterization of Radionuclide Concentrations Along the N-Springs Shoreline for 1988, WHC-SP-0480, Westinghouse Hanford Company, Richland, Washington.

Peterson, M., 1992, Integrated Program for Development of In Situ Remediation Technologies," Pacific Northwest Laboratory, Richland, Washington.

Peterson, R. E., and V. G. Johnson, 1992, Riverbank Seepage of Groundwater Along the Hanford Reach of the Columbia River Shoreline, WHC-SD-EN-TI-006, Rev. 0, Westinghouse Hanford Company, Richland, Washington.

PNL, 1993, Hanford Site Environmental Report for Caleridar Year 1992, PNL-8682, Pacific Northwest Laboratories, Richland, Washington.

Pratt, D. R., 1985, Engineering Study Liquid Effluent Disposal Facility Project H-672, UNI2999. Revision 0, Westinghouse Hanford Company, Richland, Washington.

Price, R. K., 1993, Spectral Gamma-Ray Log Report for 100 Area Borehole Surveys, WHCSD-EN-Tl-123, Rev. 0, Westinghouse Hanford Company, Richland, Washington.

RAAS, 1991, Remedial Action Assessment System, Pacific Northwest Laboratory, Richland, Washington.

Reidel, S. P., N. P. Campbell, K. R. Fecht, and K. A. Lindsey, 1993, Late Cenozic Structure and Stratigraphy of South-Central Washington, Washington Department of Natural Resources. Division of Geology and Earth Resources, Bulletin 80, in press.

Reidel, S. P., K. A. Lindsey, and K. R. Fecht, 1992, Field Trip Guide to the Hanford Site, WHC-MR-0391, Westinghouse Hanford Company, Richland, Washirigton. 
Reidel, S. P., K. R. Fecht, M. C. Hagood, and T. L. Tolan, 1989, "The Geologic Evolution of the Central Columbia Plateau", in Volcanism and Tectonism in the Columbia River Flood-Basalt Province, Special Paper 239, edited by S. R. Reidel and P. R. Hooper, Geslogical Society of Americal, Boulder, Colorado, pp. 247-264.

Reidel, S. P. and K. R. Fecht, 1981, "Wanapum and Saddle Mountains Bacalt in the Cold Creek Syncline Area," in Subsurface Geology of the Cold Creek Syncline, RHO-BWIST-14, Rockwell Hanford Operations, Richland, Washington.

Robertson, D. E., A. P. Toste, K. H. Abel, and R. L. Brodzinski, 1984, Radionuclide Migration in Groundwater, Annual Progress Report for 1982, NUREG/CR-3554, PNL-4773, Pacific Northwest Laboratory, Nuclear Regulatory Commission, Richland, Washington.

Robinson, S. M., W. D. Arnold, and C. H. Byers, 1990, Design of Fixed-Bed Ion Exchange Columns for Wastewater Treatment, Oak Ridge National Laboratory, Oak Ridge, Tennessee, Proceedings from Symposium Waste Management '90: Working Towards a Cleaner Environment.

Rokkan, D. K., 1990, Westinghouse Hanford Company 100 Areas Environmental Releases for 1989, WHC-EP-0165-2, Westinghouse Hanford Company, Richland, Washington.

Rokkan, D. K., 1988, Westinghouse Hanford Company 100 Areas Environmental Releases for 1987, WHC-EP-0165, Westinghouse Hanford Company, Richland, Washington.

Sackschewsky, M. R., 1992, Biological Assessment for Rare and Endangered Plant Species, Westinghouse Hanford Company, Richland, Washington.

Schmidt, J. W., A. R. Johnson, S. M. McKinney, C. J. Perkins, and C. R. Webb, 1992, Westinghouse Hanford Company Environmental Surveillance Annual Report, Calendar Year 1991, WHC-EP-0573, Westinghouse Hanford Company, Richland, Washington.

Spooner, P., R. Wetzel, C. Spooner, C. Furman, E. Tokarski, G. Hunt, V. Hodge, and T. Robinson, 1985. Slurry Trench Construction of Pollution Migration Control, Noyes Publications, Park Ridge, New Jersey.

Stone, W. A., J. M. Thorp, O. P. Gifford, and D. J. Hoitink, 1983, Climatological Summary for the Hanford Area, PNL-4622, Pacific Northwest Laboratory, Richland, Washington.

Tang, J. and C. M. Wai, 1989, "Transport of Trivalent Lanthanides Through a Surfactant Membrane Containing an Ionizable Macrocyclic Polyether, "Journal of Membrane Science, Vol. 46, pp. 349-356

Tang, J. and C. M. Wai, 1988, "Transport of Trivalent Lanthanides in a $\mathrm{H}_{2} \mathrm{O}-\mathrm{CHCl}_{3}-\mathrm{H}_{2} \mathrm{O}$ Liquid Membrane System Containing a Crown Ether Carboxylic Acid," Journal of Membrane Science, Vol. 35, pp. 339-345 
Wai, C. M. and H. S. Du, 1990, "Separation of Yttrium-90 and Strontium-90 on Papers Impregnated with Ionizable Crown Ethers," Analytical Chemistry, Vol. 62, pp. 24122414

Watson, J. S., C. D. Scott, B. D. Faison, 1990, "Evaluation of A Cell--Biopolymer Sorbent for Uptake of Strontium from Dilute Solutions," Emerging Technologies in Hazardous Waste Management, American Chemical Society

Watson, J. S., C. D. Scott, B. D. Faison, 1989, "Adsorption of Sr by Immobilized Microorganisms," Applied Biochemistry and Biotechnology, Vol. 20/21, pp. 699-709

WHC, 1993, Data Validation Report for the 100-NR-2 Operable Unit Soil Samples, WHCSD-EN-TI-140, Rev. 0, Westinghouse Hanford Company, Richland, Washington.

WHC, 1991, Engineering Evaluation of Containment Alternatives for $N$-Springs Releases, SD-EN-EE-003, Rev. 0, Westinghouse Hanford Company, Richland, Washington.

WHC, 1987a, Closure/Post Closure Plan 1301-N Liquid Waste Disposal Facility, Westinghouse Hanford Company, Richland, Washington.

WHC, 1987b, Closure/Post Closure Plan 1325-N Liquid Waste Disposal Facility, Westinghouse Hanford Company, Richland, Washington. 
DOE/RL-93-23, Rev. 0

APPENDIX A

COST ESTIMATES

A-1 
DOE/RL-93-23, Rev. 0 
DOE/RL-93-23, Rev. 0

\section{CONTENTS}

\section{Page}

Cost.Estimate Assumptions and Estimating Sources A-5

$\begin{array}{ll}\text { Alternative Present Worth Comparisons } & \text { A-7 }\end{array}$

$\begin{array}{ll}\text { Alternative Capital Cost Comparisons } & \text { A-8 }\end{array}$

Alternative O\&M Cost Comparisons $\quad$ A-9

Alternative 2 - Pump and Treat - Extraction System A-10

Alternative 2 - Pump and Treat - Treatment System A-13 Ion Exchange

Alternative 2 - Pump and Treat - Treatment System

Reverse Osmosis

Alternative 2 - Pump and Treat - Treated Water Disposal River Discharge

Alternative 2 - Pump and Treat - Treated Water Disposal $\mathrm{N}$ Area Crib

Alternative 2 - Pump and Treat - Treated Water Disposal N Area Reinjection

Alternative 2 - Pump and Treat - Treated Water Disposal 200 Area Crib

Alternative 3 - Vertical Barrier - Slurry Wall

Alternative 4 - Hydraulic Control - Extraction Wells 
Cost Estimate Assumptions and Estimating Sources

N Springs ERA

Assumptions:

1. Westinghouse in-house crafts install all individual pieces such as pumps, tanks, mixers, and pipe; perform site preparation; use WHC labor rates (\$53.64/hr from WHC Program Office)

2. Subcontractors install all skid-mounted packages and construct large items such as the transfer pipe to the 200 Area; also assumes that subcontractors erect buildings, install concrete floors and foundations, and perform all trenching/backfilling $(\$ 95.87 / \mathrm{hr}$ from WHC Program Office)
Sources:

1. Based on actual costs of cable tool drilling of monitoring wells by Kaiser Engineers; per foot cost from WHC Program Office; contact K. Popham

2. Richardson Cost Engineering Services, Richardson Rapid System, Process Plant Construction Estimating Standards

3. Cost quotation from Familian Northwest, Inc. (Goulds Pumps); Portland, Oregon; contact Randy Mather (503-283-3333)

4. Cost quotation from Corr Tech, Inc; Houston Texas; contact Brian Mause (713-674-7242)

5. Vatavuk, William M., Estimating Costs of Air Pollution Control, Lewis Publishers, 1990

6. Electric power rate from Benton County PUD; commercial rate for usage in the range of $2500-17500$ kw

7. Cost quotation from Babcock and Wilcox; contact Dr. Billy Bingham (804-385-3267) 
Cost Estimate Assumptions and Estimating Sources N Springs ERA

Sources (Continued)

8. WHC LLW disposal cost; contact Frank Gustavson

9. Cost quotation from Polymetrics, Inc.; contact Les Bell (719-570-7507)

10. Cost quotation from Licon, Inc.; contact Edgar Steindal (904-434-5088)

11. Cost quotation from WHC stores

12. Based on calculation brief by IT Corp.

13. Best professional judgement assumption; contact Joe Alvarez, IT Corp. (303-694-0044)

14. Based on KEH cost estimate for Project $\mathrm{C} 018 \mathrm{H}$ crib; contact Frank Gustavson

15. Based on actual costs of Odex drilling of monitoring wells in uncontaminated areas by Kaiser Engineers; per foot cost from WHC Program Office; contact K. Popham

16. Based on cost quotation from Millgard Environmental Corp.; contact Jeff Jacobs (313-261-9760) 
DOE/RL-93-23, Rev. 0

\section{Alternative Present Worth Comparisons \\ (In Millions of \$)}

Alternative 1

Alternative 2

Ion Exchange:

River Disposal

N Area Crib

N Reinjection

200 Area Crib

Reverse Osmosis:

River Disposal

N Area Crib

$N$ Reinjection

200 Area Crib

Alternative 3

Alternative 4

\section{No Action}

\$O

Five Well Three Well

$\$ 12.69$

$\$ 15.47$

$\$ 13.81$

$\$ 22.43$

$\$ 8.10$

$\$ 10.09$

$\$ 8.92$

$\$ 16.77$

$\$ 9.18$

$\$ 5.85$

$\$ 12.01$

$\$ 7.88$

$\$ 6.68$

$\$ 10.29$

$\$ 14.52$

Slurry Wall

$\$ 10.01$

Hydraulic

Control

$\$ 2.74$ 


\section{Alternative Capital \\ Cost Comparisons}

(In Millions of \$)

Alternative 1

Aftermative 2 Ion Exchange: River Disposal $N$ Area Crib $N$ Reinjection 200 Area Crib

Reverse Osmosis:

River Disposal

$N$ Area Crib

$N$ Reinjection

200 Area Crib

Alternative 3

Alternative 4
No Action

$\$ 0$

Five Well

Three Well

$\$ 4.56$

$\$ 7.35$

$\$ 5.63$

$\$ 13.49$

$\$ 3.17$

$\$ 5.17$

$\$ 3.97$

$\$ 11.35$

$\$ 3.85$

$\$ 6.63$

$\$ 4.91$

$\$ 12.77$

$\$ 2.64$

$\$ 4.64$

$\$ 3.44$

$\$ 10.83$
$\$ 10.01$

Hydraulic

Control

$\$ 2.30$ 
DOE/RL-93-23, Rev. 0

\section{Alternative O\&M \\ Cost Comparisons \\ (In Mililions of \$)}

Altornative 1

Alternative 2

Ion Exchange:

Aiver Disposal

$N$ Area Crib

$N$ Reinjection

200 Area Crib

Reverse Osmosis:

River Disposal

N Area Crib

$N$ Reinjection

200 Area Crib

Alternative 3

Alternative 4
No Action

SO

Five Well

$\$ 1.32$

$\$ 1.33$

$\$ 1.33$

$\$ 1.46$

$\$ 0.87$

$\$ 0.88$

$\$ 0.88$

$\$ 1.00$

Three Well

Slumy Wall

$\$ 0.00$

Hydraulic

Control

$\$ 0.07$
$\$ 0.80$

$\$ 0.81$

$\$ 0.81$

$\$ 0.88$

\$0.52

$\$ 0.53$

$\$ 0.53$

$\$ 0.60$ 
Alternative 2

Pump and Treat - Extraction System

\begin{tabular}{|c|c|c|}
\hline & $\begin{array}{r}\text { Five } \\
\text { Well } \\
\text { System }\end{array}$ & $\begin{array}{r}\text { Three } \\
\text { Well } \\
\text { System }\end{array}$ \\
\hline \multicolumn{3}{|l|}{ Capital Cost: } \\
\hline Wells & $\$ 193,936$ & $\$ 476,362$ \\
\hline Pumps & $\$ 16,299$ & $\$ 9,779$ \\
\hline Transfer Piping & $\$ 161,989$ & $\$ 155,253$ \\
\hline Subtotal & $\$ 972,224$ & $\$ 641,394$ \\
\hline Engineering @ 10\% & $\$ 97,222$ & $\$ 64,139$ \\
\hline Project Management @11\% & $\$ 106,945$ & $\$ 70,553$ \\
\hline Subtotal & $\$ 1,176,391$ & $\$ 776,087$ \\
\hline Contingency @30\% & $\$ 352,917$ & $\$ 232,826$ \\
\hline Total Capital Cost & $\$ 1,529,308$ & $\$ 1,008,913$ \\
\hline O\&M Cost: (Annual) & & \\
\hline Operating Labor & * & * \\
\hline Maintenance & $\$ 29,167$ & $\$ 19,242$ \\
\hline Utilities & $\$ 2,083$ & $\$ 1,086$ \\
\hline Total O\&M Cost & $\$ 31,250$ & $\$ 20,328$ \\
\hline Present Worth & $\$ 1,721,326$ & $\$ 1,133,820$ \\
\hline
\end{tabular}




\section{Pump and Treat}

System Module: Groundwater Extraction

Option: Five Well System

\begin{tabular}{|c|c|c|c|c|c|c|c|}
\hline $\begin{array}{l}\text { Cost } \\
\text { Type }\end{array}$ & Component & Description & Quantity & $\begin{array}{l}\text { Unit } \\
\text { Cost }\end{array}$ & Total, $\mathbf{s}$ & Assumption & Source \\
\hline \multirow[t]{4}{*}{ Capital } & Pumping Wells & $\begin{array}{l}\text { 6-inch diameter, } 104 \text { ft total depth, stainless steel, } \\
\text { install by cable tool drilling; costs include all materials, } \\
\text { mob/demob, drilling labor, logging, well development, } \\
\text { waste disposai, equipment decon }\end{array}$ & $520 \mathrm{ft}$ & $\$ 1526.8 / \mathrm{ft}$ & 793,936 & - & 1 \\
\hline & Pumps & $\begin{array}{l}5 \mathrm{hp}, 100 \mathrm{gpm} \text { at } 100 \mathrm{fthead} \text {, submersible, stainless } \\
\text { steel; costs include materials and instaliation }\end{array}$ & 5 & - & 16,299 & 1 & 3 \\
\hline & $\begin{array}{l}\text { Transfer piping (transfer } \\
\text { to treatment plant) }\end{array}$ & $\begin{array}{l}\text { 6-inch diameter, double wall PVC, buried below frost } \\
\text { line; costs include pipe materials, valves, valve boxes } \\
\text { and fittings, trenching, installation }\end{array}$ & $2250 \mathrm{ft}$ & -- & 147,263 & 1,2 & 4 \\
\hline & Piping leak detection & Materials and installation & - & $10 \%$ of piping & 14,726 & - & 5 \\
\hline \multirow[t]{3}{*}{ O\&M } & Maintenance & System maintenance cost & -- & $3 \%$ of capital & $\begin{array}{c}29,1671 \\
\mathrm{yr}\end{array}$ & -. & 5 \\
\hline & Operating Labor & (*Include in treatement system costs) & - & & - & - & -- \\
\hline & Elect. Power & Power for pumps; annual cost & $\begin{array}{l}62,000 \\
\mathrm{kwh} / \mathrm{yr}_{\mathrm{r}}\end{array}$ & $\$ 0.0336 / \mathrm{kwh}$ & $2,083 / \mathrm{yr}$ & -- & 6 \\
\hline
\end{tabular}




\section{Pump and Treat}

System Module: Groundwater Extraction

Option: Three Well System

\begin{tabular}{|c|c|c|c|c|c|c|c|}
\hline $\begin{array}{l}\text { Cost } \\
\text { Type }\end{array}$ & Component & Description & Quantity & $\begin{array}{l}\text { Unit } \\
\text { Cost }\end{array}$ & Total, $\mathbf{S}$ & Assumption & Source \\
\hline \multirow[t]{4}{*}{ Capital } & Pumping Wells & $\begin{array}{l}\text { 6-inch diameter, } 104 \text { ft total depth, stainless steel, install } \\
\text { by cabl= tool drilling; costs include all materials, } \\
\text { mob/demob, drilling labor, logging, well development, } \\
\text { waste disposal, equipment decon }\end{array}$ & $312 \mathrm{ft}$ & $S 1526.80 / \mathrm{A}$ & 476,362 & - & 1 \\
\hline & Pumps & $\begin{array}{l}5 \mathrm{hp}, 100 \mathrm{gpm} \text { at } 100 \mathrm{ft} \text { head, submersible, stainless steel; } \\
\text { costs include materials and installation }\end{array}$ & 3 & -- & 9,779 & 1 & 3 \\
\hline & $\begin{array}{l}\text { Transfer piping (transfer } \\
\text { to treatment plant) }\end{array}$ & $\begin{array}{l}\text { 6-inch diameter, double wall PVC, buried below frost line; } \\
\text { costs include pipe materials, valves, valve boxes and } \\
\text { fittings, trenching, installation }\end{array}$ & $2150 \mathrm{ft}$ & - & 141,139 & 1,2 & 4 \\
\hline & Leak detection & Materials and installation & - & $\begin{array}{l}10 \% \text { of } \\
\text { piping }\end{array}$ & 14,114 & - & 5 \\
\hline \multirow[t]{3}{*}{ O\&M } & Maintenance & System maintenance cost & & $3 \%$ of capital & $\begin{array}{c}19,2421 \\
\mathrm{yr}\end{array}$ & - & 5 \\
\hline & Operating labor & $(*$ Include in treatment system costs) & - & - & - & - & -- \\
\hline & Elect Power & Power for pumps; annual cost & $\begin{array}{l}32,300 \\
\mathrm{kwh} / \mathrm{yr}\end{array}$ & S0.0336/kwh & $1,086 / \mathrm{yr}$ & -- & 6 \\
\hline
\end{tabular}


DOE/RL-93-23, Rev. 0

Alternative 2

Pump and Treat - Treatment System

Ion Exchange

Capital Cost: (Installed)

Tanks and mixers

Feed pumps

IX package unit

IX pilot test by vendor

Site preparation

Treatment building

Building utilities and tie-ins

Subtotal

$\$ 1,889,496$

$\$ 1,341,461$

Engineering @ 10\%

Project Management @11\%

Subtotal

$\$ 2,286,290$

$\$ 1,623,168$

Contingency @30\%

$\$ 685,887$

$\$ 486,950$

Total Capital Cost

$\$ 2,972,177$

$\$ 2,110,118$

O\&M Cost: (Annual)

Operating

Maintenance

Waste Dipsosal

$\$ 748,980$

$\$ 56,699$

$\$ 449,445$

$\$ 485,100$

$\$ 40,233$

$\$ 291,060$

Total O\&M Cost

$\$ 1,290,779$

$\$ 780,738$

Present Worth

$\$ 10,903,455$

$\$ 6,907,415$ 
Pump and Treat

\begin{tabular}{|c|c|c|c|c|c|c|c|}
\hline \multicolumn{8}{|c|}{$\begin{array}{l}\text { System Module: Treatment } \\
\text { Description: Ion Exchange - Five Well System }\end{array}$} \\
\hline $\begin{array}{l}\text { Cost } \\
\text { Type }\end{array}$ & Component & Description & Quantity & $\begin{array}{l}\text { Unit } \\
\text { Cost }\end{array}$ & Total & Assumption & Source \\
\hline \multirow[t]{9}{*}{ Capital } & Flow Equalization Tank & $6000 \mathrm{gal}$, carbon steel/w epoxy lining, vertical & 1 & - & 14,259 & 1 & 2 \\
\hline & Equalization Tank Mixer & $6 \mathrm{hp}$. vertical/impeller type, carbon steel & $i$ & -- & 7,703 & 1 & 2 \\
\hline & Influent Feed Pump & $10 \mathrm{hp}, 500 \mathrm{gpm}$ at $40 \mathrm{f}$ head, entrifugal, carbon stecl & 2 & - & 10,959 & 1 & 2 \\
\hline & $\begin{array}{l}\text { Ion Exchange Package } \\
\text { Unit }\end{array}$ & $\begin{array}{l}\text { Vendor engineered and constructed, zeolite, non- } \\
\text { regenerative, skid-mounted, package unit, } 300 \mathrm{gpm} \\
\text { incluing pre- and post-filter units, ion exchange vessels, } \\
\text { resin storage tank, resin load-in system, resin load-out }\end{array}$ & 1 & - & $1,295,000$ & -- & 7 \\
\hline & IX Package Installation & $\begin{array}{l}\text { Freight, install package, process piping; include materials } \\
\text { and labor }\end{array}$ & 1 & -- & 477,000 & 2 & 7 \\
\hline & IX Piler Tést & Vendor pilot test & 1 & - & 45,000 & 1 & 2 \\
\hline & Site Preparation & Clear and grub site, level and compact, 2000 f 2 area & 1 & - & 8,429 & 1 & 2 \\
\hline & Treatment Building & $\begin{array}{l}1000 \mathrm{f2} \times 20 \mathrm{fthigh} \text { metal building, (Butler-type); include } \\
\text { concrete slab on grade, insulated with HVAC; include } \\
\text { materials and installation }\end{array}$ & 1 & -- & 28,323 & 2 & 2 \\
\hline & Utilities and tie-ins & $\begin{array}{l}\text { Building and process electrical, building plumbing and } \\
\text { sewer/water tie-ins }\end{array}$ & 1 & $\begin{array}{l}10 \% \text { of } \\
\text { building cost }\end{array}$ & 2,823 & 2 & 5 \\
\hline \multirow[t]{3}{*}{ O\&M } & Operating & All materials and labor, excluding waste disposal & $\begin{array}{c}157.7 \mathrm{M} \\
\mathrm{gal} / \mathrm{yr}\end{array}$ & $\$ 4.75 / \mathrm{kgal}$ & $748,980 / y r$ & - & 7 \\
\hline & Maintenance & Materials and labor & & $3 \%$ of capital & $56,699 / \mathrm{yr}$ & - & 5 \\
\hline & Waste Disposal & $\begin{array}{l}\text { Treatment residuals disposal as solid LLW; spent zeolite } \\
\text { and filter wastes }\end{array}$ & $7700 \mathrm{ft} 3 / \mathrm{yr}$ & $\$ 63 / \mathrm{A3}$ & $485,100 / y r$ & - & 8 \\
\hline
\end{tabular}


Pump and Treat

\begin{tabular}{|c|c|c|c|c|c|c|c|}
\hline & \multicolumn{7}{|c|}{ Pump and Treat } \\
\hline & \multicolumn{7}{|c|}{$\begin{array}{l}\text { System Module: Treatment } \\
\text { Description: Ion Exchange - Three Well System }\end{array}$} \\
\hline $\begin{array}{l}\text { Cost } \\
\text { Type }\end{array}$ & Component & Description & Quantity & $\begin{array}{l}\text { Unit } \\
\text { Cost }\end{array}$ & Total & Assumption & Source \\
\hline \multirow[t]{9}{*}{ Capital } & Flow Equalization Tank & $4000 \mathrm{gal}$, carbon steel/w epoxy lining, vertical & 1 & - & 11,919 & 1 & 2 \\
\hline & Equalization Tank Mixer & $4 \mathrm{hp}$, vertical/impeller type, carbon steel & 1 & - & 7,703 & 1 & 2 \\
\hline & Influent Feed Pump & $7.5 \mathrm{hp}, 300 \mathrm{gpm}$ at $40 \mathrm{ft}$ head, centrifugal, carbon steel & 2 & - & 9,755 & 1 & 2 \\
\hline & $\begin{array}{l}\text { Ion Exchange Package } \\
\text { Unit }\end{array}$ & $\begin{array}{l}\text { Vendor engineered and constructed, zeolite, non- } \\
\text { regenerative, skid-mounted, package unit, } 180 \mathrm{gpm} \\
\text { incluing pre- and post-filter units, ion exchange vessels, } \\
\text { resin storage tank, resin load-in system, resin load-out }\end{array}$ & 1 & - & 905,500 & - & 7 \\
\hline & $\begin{array}{l}\text { IX Package Unit } \\
\text { Installation }\end{array}$ & $\begin{array}{l}\text { Freight, install package, process piping; include materials } \\
\text { and labor }\end{array}$ & 1 & - & 334,000 & 2 & 7 \\
\hline & IX Pilot Test & Vendor pilot test & 1 & - & 45,000 & - & 7 \\
\hline & Site Preparation & Clear and grub site, level and compact, $1500 \mathrm{ft} 2$ area & 1 & - & 6,757 & 1 & 2 \\
\hline & Treatment Building & $\begin{array}{l}600 \mathrm{ft} 2 \times 20 \mathrm{ft} \text { high metal building, (Butler-type); include } \\
\text { concrete slab on grade, insulated with HVAC; include } \\
\text { materials and installation. }\end{array}$ & 1 & - & 18,934 & 2 & 2 \\
\hline & Utilities and Tie-ins & $\begin{array}{l}\text { Building and process electrical, building plumbing and } \\
\text { sewer/water tie-ins }\end{array}$ & 1 & $\begin{array}{l}10 \% \text { of } \\
\text { building }\end{array}$ & 1,893 & 2 & 5 \\
\hline \multirow[t]{3}{*}{ O\&M } & Operating & All materials and labor; excluding waste disposal & $\begin{array}{c}94.6 \mathrm{Mgal} / \\
\mathrm{yr}\end{array}$ & $\$ 4.75 /$ kgal & $\begin{array}{c}449,445 \prime \\
y r\end{array}$ & - & 7 \\
\hline & Maintenance & All materials and labor & & $3 \%$ of capital & $\begin{array}{c}40,233 / \\
\mathrm{yr}\end{array}$ & - & 5 \\
\hline & Waste Disposal & $\begin{array}{l}\text { Treatment residuals disposal as solid LLW; spent zeolite } \\
\text { and filter wastes }\end{array}$ & $\begin{array}{l}4620 \\
\mathrm{f} 3 / \mathrm{yr}\end{array}$ & $\$ 63 / \mathrm{A3}$ & $\begin{array}{c}291,060 l \\
\mathrm{yr}\end{array}$ & - & 8 \\
\hline
\end{tabular}


DOE/RL-93-23, Rev. 0

Alternative 2

Pump and Treat - Treatment System

Reverse Osmosis

Capital Cost: (Installed)

Tanks and mixers

Feed pumps

RO package unit

RO pilot test by vendor

Waste evaporator

Waste solidification

Site preparation

Treatment building

Building utilities and tie-ins

Subtotal

$\$ 1,434,560$

Five Three

Well Well

System System

Engineering @ 10\%

Project Management @11\%

$\$ 143,456$

$\$ 157,802$

$\$ 16,040$

$\$ 10,959 \quad \$ 7,664$

$\$ 624,900$

$\$ 437,035$

$\$ 14,000$

$\$ 14,000$

$\$ 720,000$

$\$ 503,545$

$\$ 2,191$

$\$ 1,532$

$\$ 8,429$

$\$ 5,895$

$\$ 28,323$

$\$ 19,808$

$\$ 2,823$

$\$ 1,974$

Subtotal

$\$ 1,735,818$

$\$ 1,219,068$

Contingency@30\%

$\$ 520,745 \quad \$ 365,720$

Total Capital Cost

$\$ 2,256,563$

$\$ 1,584,789$

O\&M Cost: (Annual)

Chemicals

Operating and Maintenance

$\$ 23,863 \quad \$ 14,318$

$\$ 168,800 \quad \$ 101,280$

Electric Power

$\$ 99,474 \quad \$ 59,684$

Waste disposal

$\$ 542,790$

$\$ 325,674$

Total O\&M Cost

$\$ 834,927$

$\$ 500,956$

Present Worth

$\$ 7,386,828$

$\$ 4,662,948$ 
Pump and Treat

System Module: Treatment

Description: Reverse Osmosis - Five Well System

\begin{tabular}{|c|c|c|c|c|c|c|c|}
\hline $\begin{array}{l}\text { Cost } \\
\text { Type }\end{array}$ & Component & Description & Quantity & $\begin{array}{l}\text { Unit } \\
\text { Cost }\end{array}$ & Total & Assumption & Source \\
\hline \multirow[t]{10}{*}{ Capital } & Flow Equalization Tank & $6000 \mathrm{gal}$, carbon steel/w epoxy lining, vertical & 1 & -- & 14,259 & 1 & 2 \\
\hline & Equalization Tank Mixer & $7.5 \mathrm{hp}$, vertical/impeller type, carbon steel & 1 & -- & 8.676 & 1 & 2 \\
\hline & Influent Feed Pumo & $\begin{array}{l}10 \mathrm{hp}, 500 \mathrm{gpm} \text { at } 40 \mathrm{fl} \text { head, centrifugal, carbon } \\
\text { steel }\end{array}$ & 2 & - & 10,959 & 1 & 2 \\
\hline & $\begin{array}{l}\text { Reverse Osmosis Package } \\
\text { Unit }\end{array}$ & $\begin{array}{l}\text { Vendor engineered and constructed, multi-stage, } \\
\text { skid-mounted, package unit, } 300 \mathrm{gpm} \text { incluing pre- } \\
\text { filter units, high pressure pumps, RO membranes } \\
\text { and vessels, chemical supply and metering systems }\end{array}$ & 1 & -- & 624,900 & 2 & 9 \\
\hline & Pilot Test & RO pilot test by vendor; complete & 1 & -- & 14,000 & 2 & 9 \\
\hline & Waste Evaporator & $30 \mathrm{gpm}$ vapor compression evaporator & 1 & - & 720,000 & 2 & 10 \\
\hline & Waste Solidification & $\begin{array}{l}\text { Mixing equipment for cement solidification of } \\
\text { evaporator bottoms; } 25 \mathrm{ft} 3 / \mathrm{day}\end{array}$ & 1 & - & 2,191 & 2 & 2 \\
\hline & Site Preparation & $\begin{array}{l}\text { Clear and grub site, level and compact, } 2000 \mathrm{f2} \\
\text { area }\end{array}$ & 1 & - & 8,429 & 1 & 2 \\
\hline & Treatment Building & $\begin{array}{l}1000 \mathrm{ft} \times 20 \mathrm{fthigh} \text { metal building, (Butler-type); } \\
\text { include concrete slab on grade, insulated with } \\
\text { HVAC; include materials and installation. }\end{array}$ & 1 & - & 28,323 & 2 & 2 \\
\hline & Utilities and tie-ins & $\begin{array}{l}\text { Building and process electrical, building plumbing } \\
\text { and sewer/water tie-ins }\end{array}$ & 1 & $10 \%$ of building & 2,823 & 2 & 5 \\
\hline
\end{tabular}




\begin{tabular}{|c|c|c|c|c|c|c|c|}
\hline & \multicolumn{7}{|c|}{$\begin{array}{c}\text { Sysiem Module: Treatment } \\
\text { Description: Reverse Osmosis - Five Well System }\end{array}$} \\
\hline $\begin{array}{l}\text { Cost } \\
\text { Type }\end{array}$ & Component & Description & Quantity & $\begin{array}{l}\text { Unit } \\
\text { Cost }\end{array}$ & Total & Assumption & Source \\
\hline \multirow[t]{8}{*}{ O\&M } & O\&M for RO Unit & Operating, maintenance and electrical & 1 & $108,000 / \mathrm{yr}$ & $\begin{array}{c}108,000 / \\
\text { yr }\end{array}$ & - & 9 \\
\hline & Chemical for RO & $\begin{array}{l}\text { Acid for } \mathrm{pH} \text { control, hexametaphosphate for scale } \\
\text { control }\end{array}$ & 1 & $23,863 / \mathrm{yr}$ & $\begin{array}{c}23,863 / \\
y r\end{array}$ & - & 12 \\
\hline & Operating for evaporator & Operating labor; 2 man-hours/day & $\begin{array}{c}730 \\
\text { hours/yr }\end{array}$ & $\$ 53.64 / \mathrm{mh}$ & $\begin{array}{c}39,200 / \\
\text { yr }\end{array}$ & 1 & -- \\
\hline & $\begin{array}{l}\text { Maintenance for } \\
\text { evaporator }\end{array}$ & Mainienance cost & 1 & $\begin{array}{c}3 \% \text { of evap. } \\
\text { capital }\end{array}$ & $21,600 / y r$ & - & 5 \\
\hline & $\begin{array}{l}\text { Electric power for } \\
\text { evaporator }\end{array}$ & $338 \mathrm{kw}$ connected load & $\begin{array}{l}2.96 \mathrm{M} \\
\mathrm{kwh} / \mathrm{yr}\end{array}$ & $\$ 0.0336 / \mathrm{kwh}$ & $99,400 / y r$ & -- & 10,6 \\
\hline & Evaporator waste disposal & Evaporator bottoms solidified with cement & $\begin{array}{l}7,990 \\
\mathrm{f} 3 / \mathrm{yr}\end{array}$ & $563 / \mathrm{ft} 3$ & $\begin{array}{c}503,370 \prime \\
\mathbf{y r}\end{array}$ & -- & 8 \\
\hline & Drums for solid waste & $\begin{array}{l}\text { Drums for containing the solidified evaporator } \\
\text { bottoms }\end{array}$ & $1,460 / \mathrm{yr}$ & \$27/drum & $39,420 / y \mathrm{r}$ & - & 11 \\
\hline & $\begin{array}{l}\text { Electric power for } \\
\text { solidification mixer }\end{array}$ & 1 hp motor & $\begin{array}{c}2,178 \\
k w h / y r\end{array}$ & $50.0336 / \mathrm{kwh}$ & $74 / \mathrm{yr}$ & - & 6 \\
\hline
\end{tabular}


DOE/RL-93-23, Rev. 0

\section{Alternative 2}

Pump and Treat - Treated Water Disposal System

River Discharge

Capital Cost: (Installed)

Tanks

Transfer piping/leak detection

Effluent monitoring

Subtotal

Five

Well

Three

System

Well

System

$\$ 14,259$

$\$ 9,972$

$\$ 14,661$

$\$ 12,578$

$\$ 10,000$

$\$ 10,000$

Engineering@10\%

$\$ 38,920$

$\$ 32,550$

Project Management @11\%

$\$ 3,892$

$\$ 3,255$

$\$ 4,281$

$\$ 3,581$

Subtotal

$\$ 47,093$

$\$ 39,386$

Contingency@30\%

$\$ 14,128$

$\$ 11,816$

Total Capital Cost

$\$ 61,221$

$\$ 51,201$

O\&M Cost: (Annual)

Operating labor

Maintenance

$\$ 1,167$

$\$ 700$

Total O\&M Cost

$\$ 1,167$

$\$ 700$

Present Worth

$\$ 68,392$

$\$ 55,504$

* Included in treatment plant 


\section{Pump and Treat}

System Module: Treated Water Disposal

Description: River Discharge - Five Well System

\begin{tabular}{|c|c|c|c|c|c|c|c|}
\hline $\begin{array}{l}\text { Cost } \\
\text { Type }\end{array}$ & Component & Description & Quantity & $\begin{array}{l}\text { Unit } \\
\text { Cost }\end{array}$ & Total & Assumption & Source \\
\hline \multirow[t]{4}{*}{ Capital } & $\begin{array}{l}\text { Treated water sampling } \\
\text { and collection tank }\end{array}$ & $\begin{array}{l}5000 \mathrm{gal} \text {, carbon steel } / \mathrm{w} \text { epoxy lining, vertical; include } \\
\text { level detection and control system }\end{array}$ & 1 & - & 14,259 & 1 & 2 \\
\hline & Transfer piping (to river) & $\begin{array}{l}\text { 6-inch diameter, PVC, buried, double pipe, gravity flow; } \\
\text { include valves, fittings, leak detection; include materials } \\
\text { and installation }\end{array}$ & $200 \mathrm{At}$ & -- & 13,328 & 1 & 4 \\
\hline & Piping leak detection & Materials and installation & - & $\begin{array}{c}10 \% \text { of } \\
\text { piping }\end{array}$ & 1,333 & - & 5 \\
\hline & $\begin{array}{l}\text { Instrumentation/Sr-90 } \\
\text { monitoring }\end{array}$ & Materials and installation & - & Allowance & 10,000 & - & 13 \\
\hline \multirow[t]{2}{*}{ O\&M } & Operating labor & (*Included in treatment unit) & - & - & 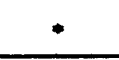 & - & - \\
\hline & Maintenance & Materials and labor & - & $\begin{array}{l}3 \% \text { of } \\
\text { capital }\end{array}$ & $1,167 / \mathrm{yr}$ & - & 5 \\
\hline
\end{tabular}


DOE/RL-93-23, Rev. 0

Alternative 2

Pump and Treat - Treated Water Disposal System

N Area Crib

\begin{tabular}{|c|c|c|}
\hline & $\begin{array}{r}\text { Five } \\
\text { Well } \\
\text { System }\end{array}$ & $\begin{array}{r}\text { Three } \\
\text { Well } \\
\text { System }\end{array}$ \\
\hline \multicolumn{3}{|l|}{ Capital Cost: (Installed) } \\
\hline Tanks & $\$ 14,259$ & $\$ 9,972$ \\
\hline Transfer piping/leak detection & $\$ 215,985$ & $\$ 185,297$ \\
\hline Pumps & $\$ 10,958$ & $\$ 7,664$ \\
\hline Effluent monitoring & $\$ 10,000$ & $\$ 10,000$ \\
\hline Disposal Crib (includes engin.) & $\$ 1,700,000$ & $\$ 1,188,926$ \\
\hline Subtotal & $\$ 1,951,202$ & $\$ 1,401,859$ \\
\hline Engineering @ 10\% & $\$ 25,120$ & $\$ 21,293$ \\
\hline Project Management @11\% & $\$ 214,632$ & $\$ 154,205$ \\
\hline Subtotal & $\$ 2,190,954$ & $\$ 1,577,357$ \\
\hline Contingency @30\% & $\$ 657,286$ & $\$ 473,207$ \\
\hline Total Capital Cost & $\$ 2,848,241$ & $\$ 2,050,564$ \\
\hline O\&M Cost: (Annual) & & \\
\hline Operating labor & * & * \\
\hline Maintenance & $\$ 7,535$ & $\$ 4,521$ \\
\hline Electric Power & $\$ 1,388$ & $\$ 833$ \\
\hline Total O\&M Cost & $\$ 8,923$ & $\$ 5,354$ \\
\hline Present Worth & $\$ 2,903,069$ & $\$ 2,083,461$ \\
\hline
\end{tabular}




\section{Pump and Treat}

System Module: Treated Water Disposal

\section{Description: N Area Crib - Five Well System}

\begin{tabular}{|c|c|c|c|c|c|c|c|}
\hline $\begin{array}{l}\text { Cost } \\
\text { Type }\end{array}$ & Component & Description & Quantity & $\begin{array}{l}\text { Unit } \\
\text { Cost }\end{array}$ & Total & Assumption & Source \\
\hline \multirow[t]{5}{*}{ Capital } & $\begin{array}{l}\text { Treated water sampling } \\
\text { and collection tank }\end{array}$ & $\begin{array}{l}6000 \mathrm{gal} \text {, carbon steel/w epoxy lining, vertical; include } \\
\text { level detection and control system }\end{array}$ & 1 & -- & 14,259 & 1 & 2 \\
\hline & Transfer piping (to crib) & $\begin{array}{l}\text { 6-inch diameter, Sch } 40 \text { PVC, buried, double pipe; include } \\
\text { valves, fittings, leak detection; include materials and } \\
\text { installation }\end{array}$ & $3000 \mathrm{ft}$ & - & 215,985 & 1 & 4 \\
\hline & Transfer pump & $\begin{array}{l}10 \mathrm{hp}, 500 \mathrm{gpm} \text { at } 40 \mathrm{fthead} \text {, centrifugal, carbon stecl; } \\
\text { include materials, installation and electrical }\end{array}$ & 2 & -- & 10,958 & 1 & 2 \\
\hline & $\begin{array}{l}\text { Instrumentation/Sr-90 } \\
\text { monitoring }\end{array}$ & Materials and installation & 1 & Allowance & 10,000 & 1 & 13 \\
\hline & Disposal Crib & Crib, $300 \mathrm{gpm}$; include design, materials, and construction & 1 & - & $1,700,000$ & 2 & 14 \\
\hline \multirow{3}{*}{ O\&M } & Operating labor & (*Included in treatment plant) & - & - & $\cdot$ & - & - \\
\hline & Maintenance & Materials and labor & - & $\begin{array}{l}\text { 3\% of capital } \\
\text { (excluding } \\
\text { crib) }\end{array}$ & $7,536 / y r$ & - & 5 \\
\hline & Power & Electric power for pump & $\begin{array}{l}41,300 \\
k w h / y r\end{array}$ & S0.0336/kwh & $1,388 / y r$ & - & 6 \\
\hline
\end{tabular}


DOE/RL-93-23, Rev. 0

Alternative 2

Pump and Treat - Treated Water Disposal System

N Area Injection Wells

Capital Cost: (Installed)

Tanks

Transfer piping/leak detection

Pumps

Effluent monitoring

Injection Wells

Five

Well

System

Three

Subtotal

$\$ 14,259$

$\$ 215,985$

$\$ 10,959$

$\$ 10,000$

$\$ 466,440$

Well

System

Engineering @ 10\%

Project Management @11\%

$\$ 717,643 \quad \$ 539,147$

Subtotal

$\$ 868,348$

$\$ 9,972$

$\$ 185,297$

$\$ 7,664$

$\$ 10,000$

$\$ 326,213$

Contingency@30\%

$\$ 260,504 \$ \$ 195,710$

Total Capital Cost

$\$ 1,128,852 \quad \$ 848,079$

O\&M Cost: (Annual)

Operating labor

Maintenance

Electric Power

$\$ 7,536$

$\$ 1,388$

$\$ 4,522$

$\$ 833$

Total O\&M Cost

$\$ 8,924$

$\$ 5,354$

Present Worth

$\$ 1,183,687$

$\$ 880,979$

* Included in treatment plant 


\section{Pump and Treat}

System Module: Treated Water Disposal

Description: N Area Reinjection - Five Well System

\begin{tabular}{|c|c|c|c|c|c|c|c|}
\hline $\begin{array}{l}\text { Cost } \\
\text { Type }\end{array}$ & Component & Description & Quantity & $\begin{array}{l}\text { Unit } \\
\text { Cost }\end{array}$ & Total & Assumption & Source \\
\hline \multirow[t]{5}{*}{ Capital } & $\begin{array}{l}\text { Treated water sampling } \\
\text { and collection tank }\end{array}$ & $\begin{array}{l}6000 \mathrm{gal} \text {, carbon steel/w epoxy lining, vertical; include } \\
\text { level detection and control system }\end{array}$ & 1 & - & 14,259 & 1 & 2 \\
\hline & $\begin{array}{l}\text { Transfer piping (to } \\
\text { injection wells }\end{array}$ & $\begin{array}{l}\text { 6-inch diameter, Sch } 40 \text { PVC, buried, double pipe; } \\
\text { include valves, fittings, leak detection; include materials } \\
\text { and installation }\end{array}$ & $3000 \mathrm{ft}$ & - & 215,985 & 1 & 4 \\
\hline & Transfer pump & $\begin{array}{l}10 \mathrm{hp}, 500 \mathrm{gpm} \text { at } 40 \mathrm{tt} \text { head, centrifugal, carbon steel; } \\
\text { include materials, installation and electrical }\end{array}$ & 2 & - & 10,959 & 1 & 2 \\
\hline & $\begin{array}{l}\text { Instrumentation/Sr-90 } \\
\text { monitoring }\end{array}$ & Materials and installation & -- & Allowance & 10,000 & 1 & 13 \\
\hline & Injection Wells & $\begin{array}{l}\text { 6-inch diameter, } 104 \mathrm{ft} \text { total depth, stainless steel, install } \\
\text { by cable tool drilling; costs include all materials, } \\
\text { mob/demob, drilling labor, logging, well development, } \\
\text { waste disposal, equipment decon }\end{array}$ & $312 \mathrm{ft}$ & $\$ 1495 / \mathrm{ft}$ & 466,440 & - & 1 \\
\hline \multirow{3}{*}{ O\&M } & Operating labor & (*Included in treatment plant) & - & - & - & - & - \\
\hline & Maintenance & Materials and labor & - & $\begin{array}{l}3 \% \text { of capital } \\
\text { (excluding } \\
\text { injection wells) }\end{array}$ & $7,535 / \mathrm{yr}$ & - & 5 \\
\hline & Power & Electric power for pump & $\begin{array}{l}41,300 \\
\mathrm{kwh} / \mathrm{yr}\end{array}$ & S0.0336/kwh & $1,388 / \mathrm{yr}$ & - & 6 \\
\hline
\end{tabular}


DOE/RL-93-23, Rev. 0

\section{Alternative 2 \\ Pump and Treat - Treated Water Disposal System 200 Area Crib}

\section{Capital Cost: (Installed) \\ Tanks \\ Transfer piping/leak detection \\ Pumps \\ Effluent monitoring \\ Disposal Crib (includes engin.)}

Subtotal

Engineering@ @10\%

Project Management @11\%

Subtotal

Contingency @30\%

Total Capital Cost

O\&M Cost: (Annual)

Operating labor

Maintenance

Electric Power

Total O\&M Cost

Present Worth

* Included in treatment plant

$\begin{array}{rr}\text { Five } & \text { Three } \\ \text { Well } & \text { Well } \\ \text { System } & \text { System }\end{array}$

$\begin{array}{rr}\$ 14,259 & \$ 9,972 \\ \$ 4,116,596 & \$ 4,116,596 \\ \$ 10,959 & \$ 7,664 \\ \$ 10,000 & \$ 10,000 \\ \$ 1,700,000 & \$ 1,188,926 \\ \$ 5,851,814 & \$ 5,333,159 \\ \$ 415,181 & \$ 414,423 \\ \$ 643,700 & \$ 586,647 \\ & \\ \$ 6,910,695 & \$ 6,334,229 \\ & \\ \$ 2,073,208 & \$ 1,900,269 \\ & \$ \$ 2,234,498 \\ \$ 8,983,903 & \$ \\ \star & \$ 74,732 \\ \$ 124,554 & \$ 5,457 \\ \$ 9,095 & \$ 80,189 \\ \$ 133,649 & \$ 8,727,227\end{array}$

$\$ 9,805,119 \quad \$ 8,727,227$ 


\section{Pump and Treat}

System Module: Treated Water Disposal

Description: 200 Area Crib - Five Well System

\begin{tabular}{|c|c|c|c|c|c|c|c|}
\hline $\begin{array}{l}\text { Cost } \\
\text { Type }\end{array}$ & Component & Description & Quantity & $\begin{array}{l}\text { Unit } \\
\text { Cost }\end{array}$ & Total & Assumption & Source \\
\hline \multirow[t]{5}{*}{ Capital } & $\begin{array}{l}\text { Treated water sampling } \\
\text { and collection tank }\end{array}$ & $\begin{array}{l}6000 \mathrm{gal} \text {, carbon steel/w epoxy lining, vertical; include } \\
\text { level detection and control system }\end{array}$ & 1 & - & 14,259 & 1 & 2 \\
\hline & $\begin{array}{l}\text { Transfer piping (to } 200 \\
\text { Area) }\end{array}$ & $\begin{array}{l}\text { 8-inch diameter, Sch } 40 \text { carbon steel, buried, double } \\
\text { pipe; include valves, fittings, leak detection; include } \\
\text { materials and installation }\end{array}$ & $48,000 \mathrm{ft}$ & - & $4,116,596$ & 2 & 4 \\
\hline & Transfer purinp & $\begin{array}{l}40 \mathrm{hp}, 300 \mathrm{gpm} \text { at } 350 \mathrm{ft} \text { head, centrifugal, carbon steel; } \\
\text { include materials, installation and electrical }\end{array}$ & 2 & - & 10,959 & 1 & 2 \\
\hline & $\begin{array}{l}\text { Instrimentation } / \mathrm{Sr}-90 \\
\text { monitoring }\end{array}$ & Materials and installation & - & Allowance & 10,000 & 1 & 13 \\
\hline & $\begin{array}{l}\text { Disposal Crib (at } 200 \\
\text { Area) }\end{array}$ & $\begin{array}{l}\text { Crib, } 300 \mathrm{gpm} \text {; include design, materials and } \\
\text { construction }\end{array}$ & 1 & - & $1,700,000$ & 2 & 14 \\
\hline \multirow{3}{*}{ O\&M } & Operating labor & (*Included in treatment plant) & - & - & 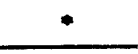 & - & - \\
\hline & Maintenance & Materials and labor & - & $\begin{array}{l}\text { 3\% of capital } \\
\text { (excluding crib) }\end{array}$ & $\begin{array}{c}124,554 / \\
y r\end{array}$ & - & 5 \\
\hline & Power & Electric power for pump & $\begin{array}{r}270,700 \\
k w h / y r\end{array}$ & $\$ 0.0336 / \mathrm{kwh}$ & $9,095 / y r$ & - & 6 \\
\hline
\end{tabular}


DOE/RL-93-23, Rev. 0

\section{Alternative 3 \\ Vertical Barrier \\ Slurry Wall}

Capital Cost: (Installed)

Slurry wall, subcontractor

$\$ 6,200,000$

installed by deep soil mixing

Testing (incl. engineering)

$\$ 200,000$

Engineering @10\%

$\$ 620,000$

Project Management @11\%

$\$ 682,000$

Subtotal

$\$ 7,702,000$

Contingency@30\%

$\$ 2,310,600$

Total Capital Cost

$\$ 10,012,600$

O\&M Cost: (Annuc

Operating labor

Maintenance

Electric Power

Tota O\&M Cost

so

Present Worth

$\$: 0,012,600$

Slurry Wall At River

Cost multiplier $=$

$(52 \mathrm{ft} \text { depth } / 104 \mathrm{ft} \text { depth })^{\wedge} 0.7=0.616$

Cost $=$

$10.01 \times 0.616$

$6,167,762$

Add. for Wetlands Analysis $2 n 0,000$

Total Cost

$\$ 6,367,762$ 
Vertical Barrier

\begin{tabular}{|c|c|c|c|c|c|c|c|}
\hline \multicolumn{8}{|c|}{$\begin{array}{l}\text { System Module: Slurry Wall } \\
\text { Description: Install By Deep Soil Mixing }\end{array}$} \\
\hline $\begin{array}{l}\text { Cost } \\
\text { Type }\end{array}$ & Component & Description & Quantity & $\begin{array}{l}\text { Unit } \\
\text { Cost }\end{array}$ & Total & Assumption & Source \\
\hline \multirow[t]{3}{*}{ Capital } & $\begin{array}{l}\text { Slurry wall installed by } \\
\text { deep soil mixing }\end{array}$ & $\begin{array}{l}\text { Vendor engineered and constructed, } 2800 \mathrm{ft} \text { long, average } \\
104 \mathrm{ft} \text { depth, includes materials and installation }\end{array}$ & $291,200 \mathrm{ft2}$ & $\$ 20.60 /: 22$ & $6,000,000$ & 2 & 16 \\
\hline & Auger replacement & Replace contaminated/broken augers & - & Allowance & 200,000 & 2 & -- \\
\hline & Field testing & $\begin{array}{l}\text { Develop appropriate slurry mixtures and demonstrate } \\
\text { constructability in Hanford soils }\end{array}$ & - & - & 200,000 & 2 & 16 \\
\hline
\end{tabular}


DOE/RL-93-23, Rev. 0

Alternative 2

Hydraulic Control

Extraction Wells

Capital Cost: (Installed)

Pumping Wells

$\$ 716,034$

Transfer piping

$\$ 698,087$

Pumps

$\$ 39,778$

Effluent monitoring

$\$ 10,000$

Subtotal

$\$ 1,463,899$

Engineering @ 10\%

$\$ 146,390$

Project Management @11\%

$\$ 161,029$

Subtotal

$\$ 1,771,318$

Contingency @30\%

$\$ 531,395$

Total Capital Cost

$\$ 2,302,713$

O\&M Cost: (Annual)

Operating labor

$\$ 39,157$

Maintenance

$\$ 22,436$

Electric Power

$\$ 9,510$

Total O\&M Cost

$\$ 71,103$

Present Worth

$\$ 2,739,610$ 


\section{Hydraulic Control}

System Module Groundwater Extraction

Description Hydraulic Control

\begin{tabular}{|c|c|c|c|c|c|c|c|}
\hline $\begin{array}{l}\text { Cost } \\
\text { Type }\end{array}$ & Component & Description & Quantity & $\begin{array}{l}\text { Unit } \\
\text { Cost }\end{array}$ & Total & Assumption & Source \\
\hline \multirow[t]{5}{*}{ Capital } & Pumping Wells & $\begin{array}{l}11 \text { wells, 8-inch diameter, } 114 \mathrm{ft} \text { total depth, stainless steel, } \\
\text { install by cable tool drilling; costs include all materials, } \\
\text { mob/demob, drilling labor, logging, well development, waste } \\
\text { disposal, equipment decon }\end{array}$ & $1254 \mathrm{ft}$ & \$571//t & 716,034 & & \\
\hline & Pumps & $\begin{array}{l}5 \mathrm{hp}, 75 \mathrm{gpm} \text { at } 100 \mathrm{f} \text { head, submersible, stainless steel; } \\
\text { costs include materials and installation }\end{array}$ & 4 & - & 14,283 & & \\
\hline & Pumps & $\begin{array}{l}7.5 \mathrm{hp}, 150 \mathrm{gpm} \text { at } 100 \mathrm{ft} \mathrm{head,} \mathrm{submersible,} \mathrm{stainless} \mathrm{steel;} \\
\text { costs include materials and installation }\end{array}$ & 2 & - & 7,642 & & \\
\hline & $\begin{array}{l}\text { Transfer piping to } \\
\text { river }\end{array}$ & $\begin{array}{l}\text { 16-inch, single wall PVC, buried below frost line; costs } \\
\text { include pipe materials, valves, valve boxes and fitings, } \\
\text { trenching, installation }\end{array}$ & $8000 \mathrm{ft}$ & -- & 698,087 & & \\
\hline & $\begin{array}{l}\text { Instrumentation/Sr-90 } \\
\text { monitoring }\end{array}$ & Materials and installation & - & Allowance & 10,000 & & \\
\hline O\&M & Elect. Power & Power for pumps; annual cost & $\begin{array}{l}283,054 \\
\mathrm{kwh} / \mathrm{yr}\end{array}$ & $\$ 0.0336 / \mathrm{kwh}$ & $9,510 / y r$ & & \\
\hline
\end{tabular}


DOE/RL-93-23, Rev. 0

DISTRIBUTION

Number of Copies

Onsite

31

U.S. Department of Energy,

Richland Field office

J. K. Erickson (30)

A5- 19

Public Reading Room

Al -65

1

Pacific Northwest Laboratory

Hanford Technical Library

P8-55

44

West inghouse Hanford Company

L. D. Arnold

B2 - 35

R. J. Gimera

F. W. Gustafson

$X 0-57$

G. C. Hencke 1

H6- 04

R. P. Hencke 1

H6- 04

W. L. Johnson

H6- 02

A. D. Krug

H6- 04

P. J. Mackey

$\mathrm{H} 6-02$

D. B. Tull is

B3-06

B. G. Tuttle

P. J. Valcich

Central Files

L6-57

N3-06

H6- 04

Correspondence Control

L8-04

EDM Group (2)

EPIC (7)

ERE Project File

ERE Records Center

ER Program Office (2)

IRA (3)

Resource Center

A3-01

H6-01

H6-08

H6- 04

H6- 07

H6-27

H4 -17

N3-05 


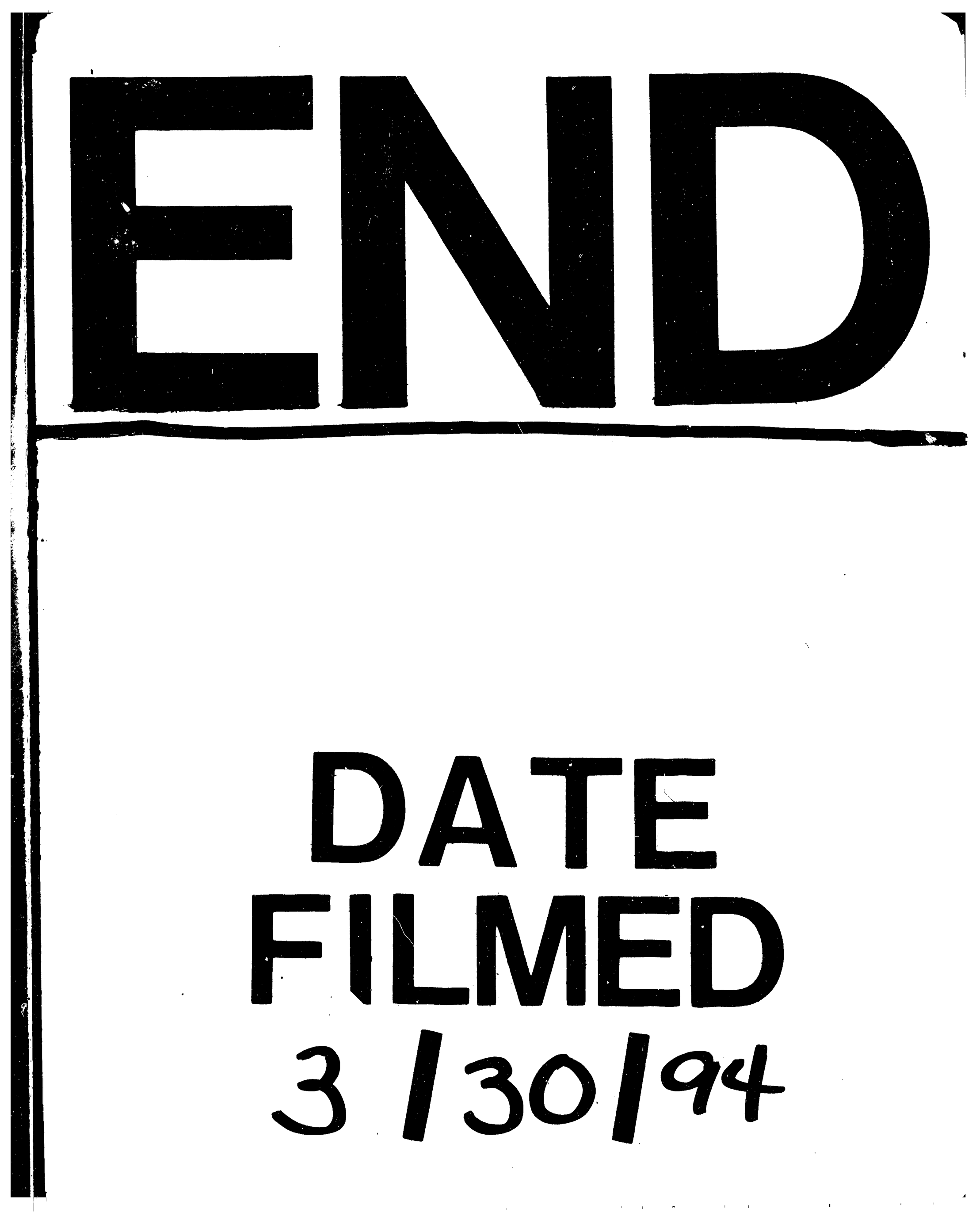


